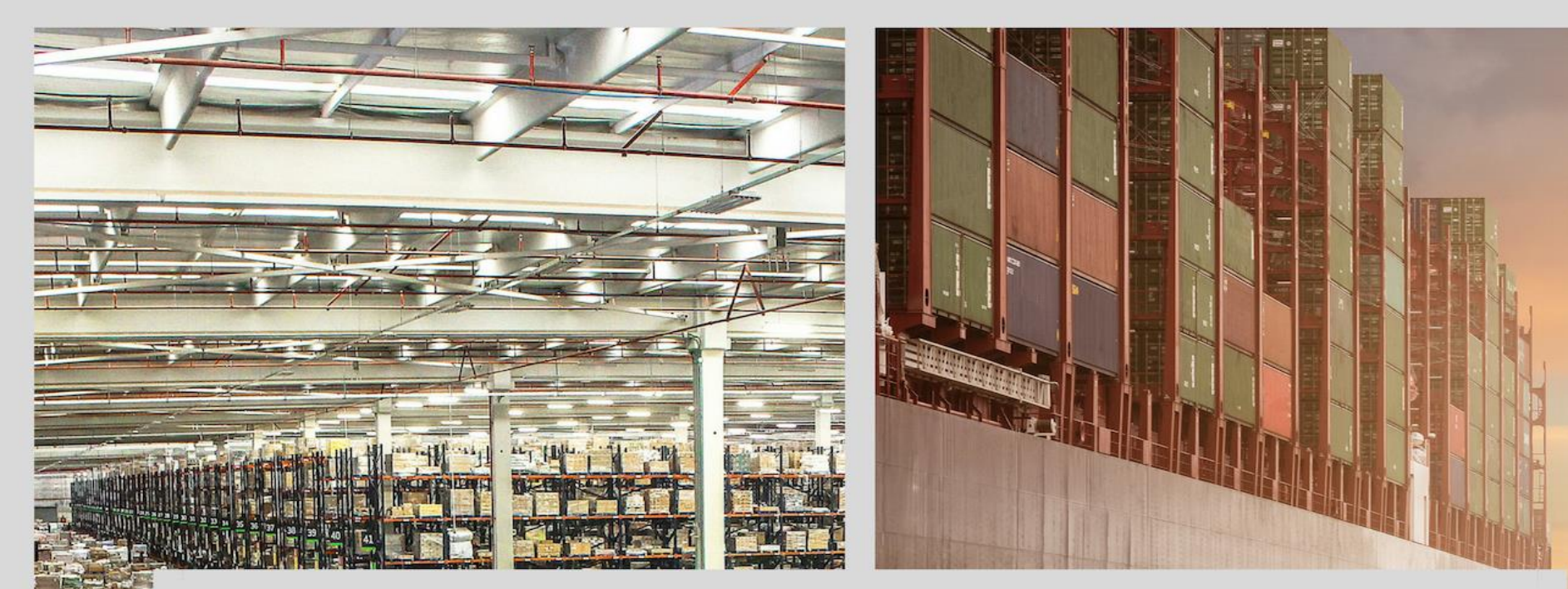

\title{
LOGÍSTICA E 0 DIFERENCIAL NAS ORGANIZAÇÕES
}

\author{
JULIO CESAR MOTA \\ RENATO MARCIO DOS SANTOS \\ JULIO CESAR RAYMUNDO \\ (ORGANIZADORES)
}

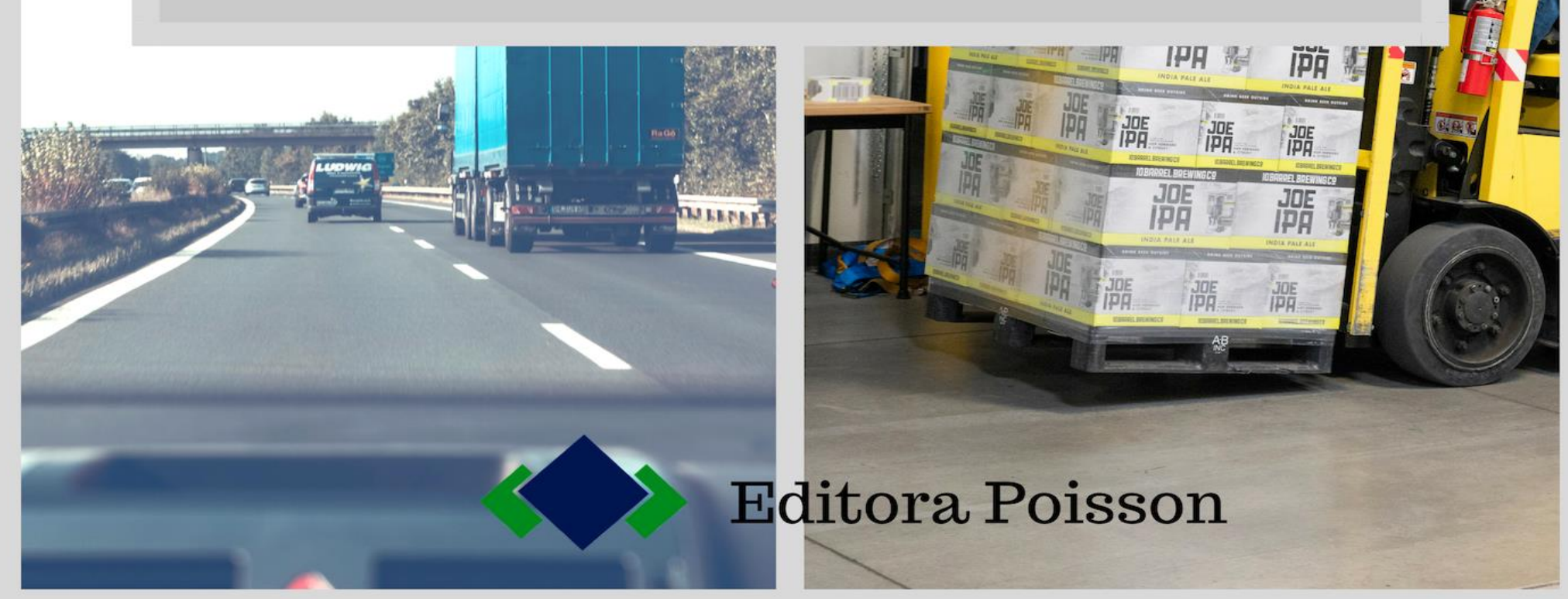




\author{
Julio César Mota \\ Renato Márcio dos Santos \\ Julio Cesar Raymundo \\ (organizadores)
}

\title{
Logística e o diferencial nas organizações
}

\author{
$1^{\mathrm{a}}$ Edição
}

Belo Horizonte

Poisson

2019 
Editor Chefe: Dr. Darly Fernando Andrade

\section{Conselho Editorial}

Dr. Antônio Artur de Souza - Universidade Federal de Minas Gerais

Ms. Davilson Eduardo Andrade

Dr. José Eduardo Ferreira Lopes - Universidade Federal de Uberlândia

Dr. Otaviano Francisco Neves - Pontifícia Universidade Católica de Minas Gerais

Dr. Luiz Cláudio de Lima - Universidade FUMEC

Dr. Nelson Ferreira Filho - Faculdades Kennedy

Ms. Valdiney Alves de Oliveira - Universidade Federal de Uberlândia

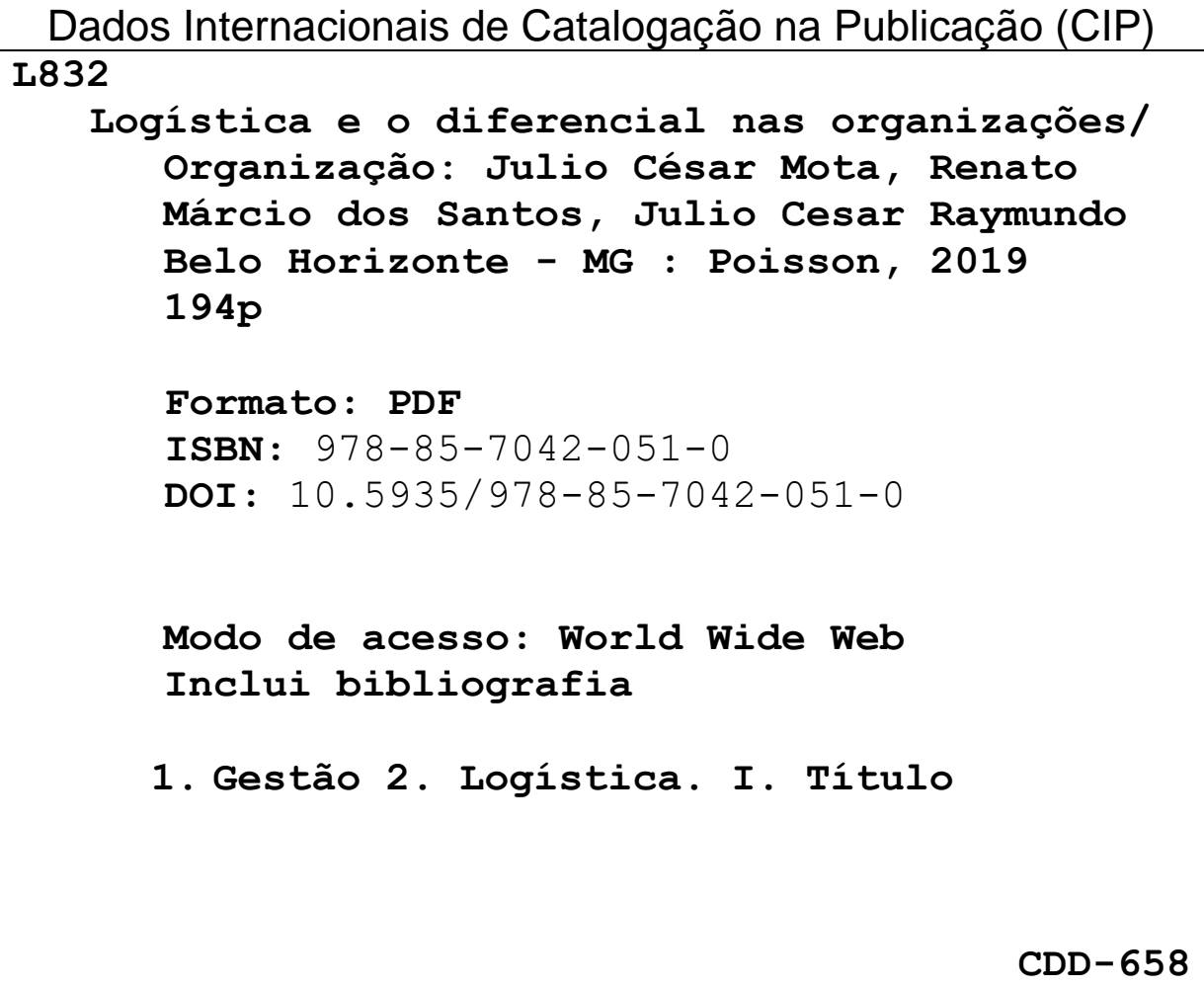

O conteúdo dos artigos e seus dados em sua forma, correção e confiabilidade são de responsabilidade exclusiva dos seus respectivos autores. 


\section{Prefácio}

As mudanças que vem ocorrendo, no atual cenário do país, apontam para uma necessária melhora para os níveis educacionais do país. A área que envolve a pesquisa é um terreno fértil e que merece, cada vez mais, ser retomada pelas Instituições de Ensino. Neste tema, os assuntos relacionados com a Logística e suas ramificações, ocupam um papel fundamental para que se possa enfrentar os problemas infraestruturais e políticos, tanto regionais como nacionais. Numa iniciativa do Centro Paula Souza foi criado o congresso denominado FATECLOG. Trata-se de um congresso, anual, promovido pelo Centro Estadual de Educação Tecnológica Paula Souza, e organizado pelo Comitê dos Coordenadores dos cursos superiores de tecnologia em Logística das FATECs. 0 foco primordial é integrar os alunos das diversas FATECs e de outras instituições aos projetos de pesquisa científica. Na sua 9a edição, o FATECLOG 2018 foi realizado na cidade de Santos-SP.

Fruto de mais de quinhentos e trinta artigos científicos aprovados e apresentados, foram selecionados os melhores, em temas considerados relevantes, e unificados passaram a compor a coletânea de assuntos que fazem parte desta publicação. Tal iniciativa, não só incentivou a produção maciça dos alunos pertencentes aos diversos cursos das FATECs, como também deixou claro o nível de tecnologia, inovação e criatividade dos dissentes.

Assuntos relacionados a logísticas específicas, como a da Força Aérea Brasileira, passando pela área de preservação ambiental e agronegócios, chegando até ao uso de tecnologia e mobilidade urbana, são alguns dos títulos abordados no presente trabalho.

A diversidade de temas e a forma de aproveitamento dos artigos apresentados, incentiva os alunos a aprofundarem e lapidarem cada vez mais suas pesquisas, buscando assuntos atuais e apresentando conclusões que podem sugerir soluções aos atrasos e gargalos existentes na Logística, e sua gama de interferências no atual cenário nacional.

A certeza é a de que uma semente saudável foi plantada para congressos futuros. As novas edições do FATECLOG deverão buscar, cada vez mais, a excelência dos trabalhos apresentados e a diversificação dos temas de maior relevância.

Os responsáveis, professores Julio Cesar Mota M. de Almeida e Renato Márcio dos Santos, conseguiram organizar um livro que poderá ser utilizado como um balizador de uma nova fórmula de melhor divulgar trabalhos acadêmicos, servindo como consulta para vários ramos da seara de gestão, tanto para empresários como executivos das diversas áreas ligadas à Logística. Também é uma obra que incentiva os futuros alunos participantes a buscarem o prêmio de verem suas criações publicadas e divulgadas.

Prezados leitores, apreciem, sem nenhuma moderação, esta obra e compartilhe de seu conteúdo com todos aqueles que estudam. A mesma é fruto único e exclusivo de alunos, que conseguiram suas vagas mediante concurso público, vindos das mais diversas faixas sociais e que possuem a filosofia e a crença de que a educação, e o seu fruto mais espontâneo, a cultura, são os pilares de uma sociedade desenvolvida e justa. Que venham outras iniciativas nessa área.

\section{Boa leitura!}




\section{SUMÁRIO}

Capítulo 1: A importância do controle de estoque no setor de perecíveis de supermercados

Elci de Sales Mota Oliveira, Acyr Elias Freire Júnior

Capítulo 2: Aproveitamento de frete na logística do etanol gera cadeia de valor para atividade TRR - Transportador Revendedor Retalhista - Estudo de caso. 15

Edi Carlos da Silva Santos, Rhadler Herculani

Capítulo 3: Atividades logísticas primárias: análise do processo logístico de dois setores da Força Aérea Brasileira-Manaus ..... 25

Henrique Menezes Nogueira, Wadna Kimberlly da Silva Alves, João Pedro Garcia de Souza, Geisy Anny Venâncio

Capítulo 4: O transporte de sangue e hemocomponentes via drones. 34 Aline Yuri Muranaka Yajima, Nataly da Silva Moraes, Marília de Souza Santos, Roberto Giusti

Capítulo 5: Proposta de implantação do sistema RFID para redução de custos operacionais: Estudo de caso de um home center que utiliza o autosserviço como método de venda..... 41

Rodrigo dos Santos Kelch, Sueli Ferreira Colona, Lucas Santos da Costa, Enio Fernandes Rodrigues

Capítulo 6: Estudo de caso: Simulação aplicada no processo de recebimento e expedição de um hipermercado 50

Peterson Rony Vicente de Matos, Cristovão Rocha Sousa, Roberto Ramos de Morais

Capítulo 7: A escala SERVQUAL na análise de qualidade da prestação de serviços logísticos 61

Luciano da Silva Ferreira,Átila de Arruda Brito,Claudio Tadeu Pinheiro de Oliveira,Roberto Kanaane

Capítulo 8: Análise crítica no processo de embarque de produtos perigosos em um aeroporto brasileiro .....

Paulo Douglas Cavalcante da Silva, Eliacy Cavalcanti Lélis

Capítulo 9: Análise sobre as condicionantes da exportação de carne de frango HALAL brasileira para países do oriente médio e islâmicos 82

Amanda Domingues, Ralph Felipe Alves Benites, Paulo Cesar Giuliani 


\section{SUMÁRIO}

Capítulo 10: Aplicação da logística aeroportuária no estudo comparativo entre os sistemas de controle manual e automático do fluxo de veículos no terminal de cargas - Estudo de caso

Thays dos Santos Vasconcelos, Samuel Victor Ricardo da Silva, Celia de Lima Pizolato, Wanny Arantes Bongiovanni Di Giorgi

Capítulo 11: Conceito colaborativo na logística brasileira: Uma análise sobre um aplicativo como ferramenta de integração entre embarcadores e transportadores autônomos 96

Caio Fabio Ferraz Santos, Marina Codo Andrade Teixeira, Paulo Cesar Giuliani

Capítulo 12: Contribuições dos sistemas Lean para a criação de processos de um estúdio experimental de design..... 105

Edney Eboli dos Santos, Gabriel José Barbosa, Marília Macorin de Azevedo, Antonio César Galhardi, Daiane Belchior, Atila de Arruda Brito

Capítulo 13: Estudo de caso sobre a redução de lead time em atividade de separação e expedição

Leandro de Souza Santos, Paulo Cesar Giuliani

Capítulo 14: Melhoria do trânsito em um cruzamento de vias sinalizado por semáforo sob a ótica da pesquisa operacional

Luciana Vasques Sanches Cardoso, João Carlos Teixeira dos Santos

Capítulo15: Metodologia ativa como ferramenta de ensino e aprendizagem em cursos de logística

Juliana Ferreira de Vales, Julio Cesar Ferreira dos Passos, José Carlos Redaelli, Orlando Fontes Lima Junior

Capítulo 16: Transporte urbano de cargas: Uma indicação operacional para favorecer a mobilidade urbana através do VLT Baixada Santista 


\section{SUMÁRIO}

Capítulo 17: Logística no e-commerce: visão do consumidor 156

Cibelle William Costa, Suellen Yañes da Silva, Edna Veloso de Medeiros

Capítulo 18: Os ganhos de produtividade com o uso do metodo $A B C$ no gerenciamento da armazenagem e estoque: Estudo de caso na empresa JFL Fios e Cabos 163

Fernando Júlio Martines, Júnior Lemes, Marcos Antônio Luciano

Capítulo 19: Processos críticos na cadeia de suprimento - impacto climático no período sazonal na produção da laranja e exportação: Abordagem da teoria da restrição (TOC)......

Barbara Soares da Silva, Heberty da Silva, Leticia Perez da Silva, Renata dos Santos de Andrade

Capítulo 20: A real situação do transporte de cargas no Brasil 179 Luana Lima da Silva, Nelson Henrique Moreira, Patricia Carbonari Pantojo

Autores: 185 


\section{Gapítulo 1}

\section{A IMPORTANACIA DO CONTROLE DE ESTOQUE SETOR DE PERECIVEIS DE SUPERMERCADOS}

\section{Elci de Sales Mota Oliveira}

Acyr Elias Freire Jr.

Resumo: A logística possui vários papéis nas organizações, dentre os quais se encontram: o manuseio, armazenamento, controle e redução de custos. Para que isso aconteça, é necessário que os processos sejam aplicados de forma que ocorra a maximização da gestão dos setores decorrentes. Neste trabalho busca-se analisar como as ferramentas de auxílio à administração de estoques podem contribuir com a redução das perdas de produtos perecíveis dos supermercados. A metodologia utilizada apresentou caráter descritivo e exploratório, com abordagem qualitativa e quantitativa. Foram utilizadas entrevistas com funcionários de setores de perecíveis de três supermercados da cidade de Caraguatatuba, sendo que cada um deles pertence a um seguimento sendo: um hipermercado, um atacadista e um supermercado popular com maior movimento e com maior fluxo de clientes, autogiro de mercadorias. Os dados coletados foram alocados em tabelas de acordo com o questionário aplicado nos setores, questionário esse que abordou a funcionalidade das rotinas de estocagem, e o conhecimento das formas de estocagem e armazenagem do seguimento supermercadista.

Palavras-chave: Perecíveis; Logística; Controle de estoque; Armazenagem 


\section{INTRODUÇÃO}

O setor de perecíveis é o setor com mais perdas dentro do seguimento supermercadista por tanto, é necessário que se tenha um maior controle sistêmico e/ou manual, melhor será o controle de cada item estocado. O primeiro pensamento que passa na cabeça do consumidor final é a data de validade, porém, existem outros fatores que podem comprometer a integridade do produto e uma das principais é a forma de armazenagem elou estocagem de mercadorias desde seu recebimento, seja vindo de fornecedores ou de CD (Centros de Distribuição) que abastecem os supermercados dentre outros comércios do ramo local.

O setor supermercadista é muito complexo pela diversidade de produtos de características distintas que requer o maior controle possível para evitar perdas, o que reflete diretamente no resultado da empresa.

Este trabalho mostrará a estocagem e armazenagem em três tipos de supermercados sendo um hipermercado, um atacadista e um supermercado maior com fluxo de clientes abundante e giro de estoque corrente, para explanar as várias formas características de cada setor.

\subsection{PROBLEMA}

Os produtos existentes nos setores de perecíveis dos supermercados possuem características distintas, assim, necessitam diversas condições de temperatura e armazenagem, além de carecerem de atenção com relação ao risco de contaminação cruzada, controle de datas, controle de fracionamento, pesagem e qualidade do produto.

Entretanto, existem ferramentas que auxiliam os gestores a aperfeiçoarem o controle de estoques de melhores formas para cada tipo e necessidade setorial, como planilha de controle, conferência no recebimento, mecanismos de rebaixa de preços dentre outros, porém, ainda são setores que representam perdas significativas para as organizações.

Neste contexto, problematiza-se a identificação de quais as dificuldades que os gestores de perecíveis enfrentam em relação às ferramentas de controle de estoque dos supermercados da região de Caraguatatuba.

\subsection{HIPÓTESE}

As ferramentas de controle de estoque têm papel fundamental quando bem utilizadas em todos os setores independente dos produtos, entretanto, o setor de perecíveis é muito complexo, pois, envolve vários aspectos como: validade, temperatura, contaminações devido armazenamento inadequado, dentre outros aspectos fundamentais para obter um bom resultado e acuracidade nos inventários realizados.

De acordo com Faria (2003), citado por Ching (p.188,1999)

\begin{abstract}
"armazenagem pode ser definida como sendo - conjunto de atividades para manter fisicamente estoques de forma adequada. Requer que a localização, dimensionamento da área, arranjo físico, alocação dos estoques, projeto de docas e configuração dos armazéns, tecnologia de movimentação interna, estocagem e sistemas estejam solucionados. Custos de armazenagem são os aplicados nas estruturas e condições necessárias para a empresa armazenar seus produtos adequadamente".
\end{abstract}

O grau de conhecimento dos gestores de estoque é imprescindível para melhor aproveitamento das ferramentas de controle visando a manutenção do estoque e não apenas dos gestores, mas, também, de toda a equipe que envolve os setores.

A coleta de informações e o armazenamento dos dados agregados ao comprometimento da equipe trará um ótimo resultado para a organização e para todos os envolvidos, evitando perdas e prejuízos às companhias, no entanto, os equipamentos e as áreas físicas também precisam estar coerentes às necessidades dos setores, evitando não apenas perdas, mas também possíveis problemas com órgão sanitários dentre outros que possam vir a multar ou até mesmo interditar parcial ou totalmente o local de armazenamento do supermercado.

\section{OBJETIVOS}

\subsubsection{OBJETIVO GERAL}

Descrever as dificuldades e a utilização das ferramentas de controle de estoque do setor de perecíveis que os gestores enfrentam para manter seus estoques básicos garantindo a qualidade e o armazenamento adequados. 


\subsubsection{OBJETIVOS ESPECÍFICOS}

Descrever as dificuldades que os gestores de estoque de perecíveis enfrentam desde o recebimento das mercadorias até a venda dos produtos.

Explanar sobre a funcionalidade sistêmica de controle, como ajuste de parâmetros e necessidade de ressuprimento de estoque.

Demonstrar de que forma as ferramentas são utilizadas e contribuem para o resultado da empresa.

\subsubsection{METODOLOGIA DE PESQUISA}

Essa pesquisa tem natureza qualitativa e quantitativa com objetivos exploratórios, utilizando informações coletadas através de minha experiência profissional como chefe de perecíveis e também a um questionário aplicados a responsáveis e colaborados das áreas de supermercados da cidade de Caraguatatuba.

Com embasamento teórico bibliográfico e pesquisa em livros da área de logística de estoque e armazenagem.

\section{EMBASAMENTO TEÓRICO OU REVISÃO DA LITERATURA}

De acordo com Hong Yuh Ching (2010), o conceito logístico existe desde a década de 40 utilizado pelas forças armadas norteamericanas, relacionando-o a todo processo de aquisição e fornecimento de materiais durante a segunda guerra mundial, e foi utilizado por militares americanos para atender a todos os objetivos de combate da época, em outras palavras, é a execução das atividades relativas a movimentação de materiais e ao fluxo de informações, do fornecedor ao consumidor final e vice versa, é realizada de forma segmentada.

O autor afirma que o gerenciamento logístico engloba, portanto, os conceitos de fluxo de compras de matérias-primas, operações de produção e transformação, controle de materiais e processos, bem como produtos acabados, compreendendo também todo o gerenciamento de transporte e distribuição de produtos.

De acordo com Slack, Chambers, Harland et al (1997, p.423) citado por Hong Yuh Ching,(1999) a gestão de estoque originou-se na função de compras em empresas que compreenderam a importância de integrar o fluxo de materiais a suas funções de suporte, tanto por meio de negócios, como por meio do fornecimento aos clientes imediatos. Isso inclui a função de compras, de acompanhamento, gestão de distribuição física.

Explica Moura (1997) que a função da atividade de estocagem é guardar, proteger e preservar o material, até que o mesmo seja requerido para o uso, uma maneira de se ter uma operação eficiente são o planejamento e - layout apropriado das dimensões da área de estocagem.

O setor supermercadista é composto por vários tipos de setores perecíveis dos mais diversos produtos com características ímpares, são eles:

- $\quad$ FLV (Frutas, Verduras e legumes); Setor bastante delicado devido a rápida maturação dos produtos, são inúmeros tipos para um público diversificado. Tendo em vista a boa aparência o estoque tem que ser baixo para diminuir as perdas, por outro lado há itens que necessitam ter um volume devido o preço e a época de colheita, fazendo com que o gestor de estoque tenha que pedir uma quantidade acima do normal para atender a demanda um exemplo físico disso é o tomate, um produto que tem frequentes discrepâncias de preços o que não facilita o controle do produto gerando perdas para o setor.

- Padaria, Rotisserie; Setores voltados à produção que além do estoque de produtos acabados tem que trabalhar com o de matéria prima também. Dois estoques distintos com inúmeros produtos com datas mais curtas e também mais extensas o que dificultam os controles por datas.

- Frios processados; Talvez um dos maiores desafios para gestores de estoque devido sua diversificação de produtos, armazenagens de diferentes ingredientes que caso armazenados de forma inadequada podem causar danos à saúde do consumidor devido a possível contaminação cruzada e prejuízos financeiros devidos perdas por má armazenagem e administração do mesmo.

- Frios industrializados, Massas e Laticínios, Congelados; Estes por sua vez são apenas setores de armazenagem e abastecimento, contudo, as mercadorias chegam em grande volume e com datas diversas e o fator "degustação" também 
interfere e muito na hora de análise de estoque (inventários).

- $\quad$ Açougue e Peixaria; A carne animal é um dos produtos de alto custo por se tratar de um produto com grande risco de contaminação característico como contaminação cruzada, salmonela, dentre outros tipos de contaminação é imprescindível um minucioso controle de datas e armazenagem dos mesmos.

A entrada dos produtos a vácuo no mercado facilitou o controle de estoques, por datas de validade, assim se prolonga mais a vida útil do produto, o que aumentou a venda já que, a maior parte dos consumidores aderiu a compra de peças a vácuo, que de certa forma passa mais confiabilidade de qualidade ao consumidor. No entanto, todos estes setores têm características em comum, como a forma de higienização constante para evitar a proliferação de fungos e outras substâncias insalubres. Um supermercado tem vários tipos de produtos com características diferentes e sendo assim, diferentes formas de estocagem. O setor de perecíveis é determinante para um bom resultado dependendo dos níveis de controle e acuracidade entre inventários gerais ou parciais.

A logística é uma ferramenta de extrema importância para o controle de estoque. A armazenagem não pode ser tratada como um problema isolado e sim deve ser analisada como um processo interligado a todas as outras atividades da empresa, independente do ramo de atividade.

Para obter resultados com a utilização da logística nas empresas é necessário entender as características de cada produto, necessidade de estocagem, custos de armazenagem, local físico adequado para produto, demanda versus pedido etc. A disposição dos produtos de acordo com a necessidade da procura também auxiliará em aproveitamento de espaço físico e melhor controle de datas utilizando o método PVPS (primeiro que vence, primeiro que sai), tanto na entrada, os setores perecíveis são extremamente delicados por fatores característicos como: validade, manuseio, oscilações de temperaturas, dentre outros fatores insalubres que podem levar a perda parcial ou até mesmo ao total de estoque devido as inúmeras possibilidades de contaminações cruzadas decorrentes de faltas de conformidades e orientação de maneiras corretas de recebimento e armazenagem.

\section{RESULTADOS E DISCUSSÃO}

A revisão bibliográfica nos parágrafos anteriores reforça a importância do gerenciamento de estocagem, bem como a junção das informações de controle de estoque e a preparação física de estocagem, são fundamentais para a empregabilidade dos processos de gestão de estoque.

Apesar do avanço tecnológico, a maioria dos gestores de estoque utilizam planilhas manuais para conferir o controle de datas, até mesmo porque em se tratando de produtos perecíveis é necessária também a parte visual para garantir a integridade dos produtos.

As entrevistas aplicadas apresentaram os seguintes aspectos:

- No hipermercado o quadro de funcionários que trabalham na área de perecíveis é de 24 funcionários sendo, 4 chefes de seção, dos quais foram entrevistados $100 \%$ do quadro, o inventário é feito de forma manual inicialmente e depois passado para o sistema para apurar os resultados, feito uma vez por mês e as câmaras são compartilhadas temporariamente entre setores.

- No supermercado popular o quadro de 23 funcionários sendo 4 chefes de seção. O inventário também é feito mensalmente e as câmaras são compartilhadas em período integral. Devido ao grande fluxo de clientes alguns processos de controle de estoque como, por exemplo, o controle de datas é deixado para trás.

- E por final no mercado atacadista, o quadro total é de 10 funcionários sendo apenas 1 chefe de seção responsável por toda área. Segundo o chefe da seção o quadro é suficiente pois é um seguimento de auto serviço não tendo áreas de produção assim, os funcionários tem mais tempo para auxiliar no controle de perdas do estoque , o inventario é $100 \%$ informatizado e feito diariamente por 2 estoquistas responsáveis pelo controle das câmaras, o recebimento é feito de forma rígida e em alguns casos é acompanhado pelo chefe de setor, um da expedição e outro da prevenção de perdas, além de terem uma pré-câmara.

- Foram aplicadas 20 questões sendo, 10 para nível hierárquico e 10 para o nível 
operacional conforme demostrado nas tabelas um e dois.

Tabela 1- entrevista para nível hierárquico

6 chefes de hipermercado- 5 chefes de supermercado- 1 chefe de atacadista

\begin{tabular}{|c|c|c|c|}
\hline \multicolumn{4}{|c|}{ Entrevista para nível hierárquico } \\
\hline & \multicolumn{3}{|c|}{ Entrevistados } \\
\hline Questões & Hipermercado & Supermercado & Atacadista \\
\hline $\begin{array}{l}\text { 1- como é feito o controle de } \\
\text { estoque? }\end{array}$ & $\begin{array}{l}50 \% \text { informatizado } \\
50 \% \text { manual }\end{array}$ & $\begin{array}{l}50 \% \text { informatzado } \\
50 \% \text { manual }\end{array}$ & $100 \%$ informatizado \\
\hline $\begin{array}{l}\text { 2- as câmaras de refrigeração e } \\
\text { congelamento são compartilhadas } \\
\text { com outros setores? }\end{array}$ & $100 \%$ & $100 \%$ & Temporariamente \\
\hline $\begin{array}{l}\text { 3- quem é responsável pelo } \\
\text { recebimento de mercadorias nas } \\
\text { docas ou local de desembarque? }\end{array}$ & $\begin{array}{l}\text { Chefe ou funcionário } \\
\text { da seção }\end{array}$ & $\begin{array}{l}\text { Funcionário do } \\
\text { depósito }\end{array}$ & $\begin{array}{l}\text { Funcionário de } \\
\text { expedição + lider da } \\
\text { seção }\end{array}$ \\
\hline $\begin{array}{l}\text { 4- no ato do recebimento é feito } \\
\text { medição de temperatura dos } \\
\text { produtos e do meio de trasporte? }\end{array}$ & $\begin{array}{l}\text { Com pouca } \\
\text { frequência } 80 \%\end{array}$ & $\begin{array}{l}\text { Com pouca } \\
\text { frequência } 70 \%\end{array}$ & $100 \%$ \\
\hline $\begin{array}{l}\text { 5- no ato do recebimento as } \\
\text { mercadorias são pesadas para } \\
\text { confrontar com o que condiz na nota } \\
\text { fiscal? }\end{array}$ & $\begin{array}{l}\text { Quando há pessoal } \\
\text { disponível }\end{array}$ & Sim, todas & Sim \\
\hline $\begin{array}{l}\text { 6- pars (produtos de alto risco) tem } \\
\text { maior controle no ato do recebimento } \\
\text { (carnes, queijos especiais...)? }\end{array}$ & Sim & Sim & $\begin{array}{c}\text { Sim, com } \\
\text { acompanhamento de } \\
\text { prevenção }\end{array}$ \\
\hline $\begin{array}{l}\text { 7- as mercadorias vêm direto de cds } \\
\text { (centros de distribuição) ou de } \\
\text { fornecedores próprios das marcas? }\end{array}$ & $\begin{array}{c}80 \% \text { de cds } \\
20 \% \text { de fornecedores }\end{array}$ & $\begin{array}{l}60 \% \text { de cds } \\
40 \% \text { de } \\
\text { fornecedores }\end{array}$ & Das duas formas \\
\hline $\begin{array}{l}\text { 8- quem é responsável pelo controle } \\
\text { de datas? }\end{array}$ & $\begin{array}{l}\text { Funcionário } \\
\text { responsável por } \\
\text { cada posto } \\
\text { específico }\end{array}$ & $\begin{array}{l}\text { Funcionários e } \\
\text { promotores }\end{array}$ & $\begin{array}{l}\text { Todos os envolvidos } \\
\text { com o setor }\end{array}$ \\
\hline $\begin{array}{l}\text { 9- utiliza histórico de vendas como } \\
\text { parâmetro de novos pedidos? }\end{array}$ & Sim & Sim & Sim \\
\hline $\begin{array}{l}\text { 10- qual o período de intervalo entre } \\
\text { inventários? }\end{array}$ & 1 mês & 1 mês & Diário por escala \\
\hline
\end{tabular}

Fonte: elaborada pelos autores 
Tabela 2- Entrevista para nível operacional

20 funcionários de hipermercado-10 de supermercado-6 de atacadista

\begin{tabular}{|c|c|c|c|}
\hline \multicolumn{4}{|c|}{ Entrevista para nível operacional } \\
\hline \multirow[b]{2}{*}{ Questões } & \multicolumn{3}{|c|}{ Entrevistados } \\
\hline & Hipermercado & Supermercado & Atacadista \\
\hline \multirow{2}{*}{$\begin{array}{l}\text { 1-tem interesse em aprender sobre o controle } \\
\text { de estoque do seu setor? }\end{array}$} & $12 / 20 \mathrm{sim}$ & \multirow{2}{*}{$10 / 10 \mathrm{sim}$} & \multirow{2}{*}{ 06/06 sim } \\
\hline & 08/20não & & \\
\hline \multirow{2}{*}{$\begin{array}{l}\text { 2-recebe treinamento ou orientações sobre } \\
\text { controle de estoque? }\end{array}$} & \multirow{2}{*}{ 20/20 sim } & $05 / 10 \operatorname{sim}$ & \multirow{2}{*}{ 06/06 sim } \\
\hline & & 05/10 não & \\
\hline $\begin{array}{l}\text { 3-considera a forma de organização de } \\
\text { estoque: }\end{array}$ & $\begin{array}{l}\text { 08/20 satisfatória } \\
\text { 12/20 insatisfatória }\end{array}$ & $\begin{array}{c}04 / 10 \\
\text { satisfatória } \\
06 / 10 \\
\text { insatisfatória }\end{array}$ & $\begin{array}{c}\text { 05/06 } \\
\text { satisfatória } \\
01 / 06 \\
\text { insatisfatória }\end{array}$ \\
\hline $\begin{array}{l}\text { 4-a empresa adota o controle de datas pvps } \\
\text { (primeiro que vence primeiro que sai)? }\end{array}$ & $\begin{array}{l}\text { 05/20 desconhecem } \\
15 / 20 \mathrm{sim}\end{array}$ & $10 / 10 \mathrm{sim}$ & 06/06 sim \\
\hline \multirow{2}{*}{$\begin{array}{l}\text { 5-tem conhecimento dos dias de estoque do } \\
\text { seu setor? }\end{array}$} & $02 / 20 \operatorname{sim}$ & \multirow{2}{*}{ 10/10 não } & \multirow{2}{*}{$\begin{array}{l}\text { 04/06 sim } \\
\text { 02/06 não }\end{array}$} \\
\hline & 18/20 não & & \\
\hline 6- considera o espaço físico de estocagem: & $\begin{array}{l}\text { 12/20 satisfatório } \\
\text { 08/20 insatisfatório }\end{array}$ & $\begin{array}{l}10 / 10 \\
\text { satisfatório }\end{array}$ & 06/06 sim \\
\hline \multirow{2}{*}{$\begin{array}{l}\text { 7- recebe informaçoes sobre os numeros da } \\
\text { seção? (quebra, regressão, progressão...) }\end{array}$} & $14 / 20 \operatorname{sim}$ & $02 / 10 \mathrm{sim}$ & \multirow{2}{*}{ 06/06 sim } \\
\hline & 06/20 não & 08/10 não & \\
\hline $\begin{array}{l}\text { 8- os equipamentos de recebimentos } \\
\text { (plataformas, hidraulicos, balanças } \\
\text { empilhadeiras...) Estão em bom estado de } \\
\text { coservação? }\end{array}$ & 20/20 a maioria & $\begin{array}{c}10 / 10 \\
\text { parcialmente }\end{array}$ & 06/06 total \\
\hline \multirow{2}{*}{$\begin{array}{l}\text { 9-tem facilidade de trabalhar com } \\
\text { informatização? }\end{array}$} & $17 / 20 \operatorname{sim}$ & $08 / 10 \operatorname{sim}$ & \multirow{2}{*}{ 06/06 sim } \\
\hline & 03/20 não & 02/10 não & \\
\hline \multirow{2}{*}{ 10-participa dos inventários? } & 09/20 sim & $03 / 10 \operatorname{sim}$ & \multirow{2}{*}{$\begin{array}{l}\text { Diário por } \\
\text { escala }\end{array}$} \\
\hline & 13/20 não & 07/10 não & \\
\hline
\end{tabular}

Fonte: elaborada pelos autores

\section{CONSIDERAÇÕES FINAIS}

Os resultados desta pesquisa indicam que o compartilhamento das informações bem como as formas de armazenagem e áreas destinadas para desembarque e estocagem, devem ser minuciosamente controladas, as perdas dos setores de perecíveis são inevitáveis, porém podem ser minimizados com uma boa gestão, pessoas comprometidas e treinadas. A tecnologia é peça fundamental para a otimização da coleta de dados e confrontamento de informações assim como o intervalo entre inventários quanto menor melhor será o resultado pois, será possível visualizar os erros de contagem e até mesmo localizar de onde estão vindas as possíveis perdas.

A limitação dessa pesquisa foi a dificuldade que as empresas desse ramo têm em disponibilizar os entrevistados para a confecção do questionário e insegurança de disponibilizar dados para trabalhos acadêmicos e, de alguns entrevistados que não tinham conhecimento e /ou não demostraram interesse em se atualizar e aprender sobre o mesmo. 
Alguns funcionários ainda são resistentes as mudanças sistêmicas e/ou tem dificuldades de assimilarem informações fundamentais para uma boa gestão de estoque, o que

\section{REFERÊNCIAS}

[1]. Alvarenga, A. C. ; NOvaES, A. G. N. Logística aplicada: suprimento e distribuição física. 3. Ed. 1. reimp. São Paulo: Edgard Blücher, 2000. $194 \mathrm{p}$.

[2]. CHING, H.Y. Gestão de estoque na Cadeia de Logística Integrada. São Paulo: Atlas, 1999.

[3]. DIAS, M. A. Administração de materiais: edição compacta.4. ed. são Paulo: Atlas,1995. dificulta no controle e armazenagem do setor, bem como a integridade dos equipamentos e áreas de armazenagem contribuem para o mesmo.

[4]. MOREIRA, D. A. Administração da Produção e Operações. São Paulo: Pioneira, 1993.

[5]. MOURA, R.AP. Manual de logística; armazenagem e distribuição física, 2.ed. São Paulo IMAM, 1997.

[6]. SLACK, N.; CHAMBERS.; JOHNSTON, R. Administração da produção 2.ed. São Paulo :Atlas, 2009. 


\section{Bapítulo 2}

\section{APROVEITAMENTO DE FRETE NA LOGÍSTICA DO ETANOL GERA CADEIA DE VALOR PARA ATIVIDADE TRR TRANSPORTADOR ESTUDO DE CASO}

\section{Edi Carlos da Silva Santos}

\section{Rhadler Herculani}

Resumo: O presente estudo tem por objetivo analisar os processos logísticos entre um Transportador Revendedor Retalhista - TRR e empresas que atuam no transporte de combustível. Atualmente, estas têm um papel fundamental na elaboração do fluxo logístico, principalmente do etanol. Isto porque grande parte do etanol que não é absorvido pelo modal dutoviário no noroeste do estado, passa a ser transferido para o modal rodoviário. E é justamente neste ponto onde a parceria gera uma cadeia de valor, pois como é de interesse das organizações a busca constate por redução de custos operacionais e aumento do faturamento. Os TRRs, para conseguir uma margem melhor de lucro, alinham-se com os assessores das companhias de petróleo e as transportadoras, para viabilizar todas as informações sobre o planejamento logístico. As compras do diesel passam a ser efetuadas nas bases da capital ou onde o assessor conseguir o custo do litro mais barato. Como as empresas de transportes estão com foco nas rotas do retorno do etanol desta região, eles então fazem a retirada do diesel nas bases destinadas pelos assessores, e após efetuam as entregas do diesel no destino; já estão com a programação de coleta do etanol em uma das usinas da região, concluindo assim todo fluxo logístico.

Palavras chave: Custos. Informações. Integração. Logística. Planejamento. 


\section{INTRODUÇÃO}

O Transportador Revendedor Retalhista (TRR) tema do estudo deste artigo, é a empresa que se destina a venda retalhista de óleo diesel e entrega em domicilio de qualidade a seus clientes, toda aquisição do óleo diesel é efetuada por intermédio de assessores das companhias distribuidoras de petróleo como BR, RAIZEN, IPIRANGA entre outras, procurando sempre o menor custo, para que isto tenha uma sinergia perfeita entre todo o ciclo pedido, carregamento e o descarregamento o transportador tem um papel fundamental na elaboração de todo fluxo logístico.

O objetivo principal é entender e elaborar uma logística eficiente tanto para o TRR como para os Transportadores a fim de beneficiar ambos na sobrevivência, solidez e competitividade de suas organizações.

Segundo Bertaglia (2010, p. 34) as organizações para terem sucesso no mercado competitivo global dependem extremamente do relacionamento que mantêm com seus fornecedores para atender eficientemente suas demandas, os envolvidos neste processo devem ter flexibilidade e agilidade.

Já o autor Faria (1994) relata que a prática da terceirização do fornecimento de insumos não é novidade nas organizações e está relacionada com a competitividade, produtividade e a qualidade.

Este mesmo autor comenta que, com a terceirização, a empresa concentra-se no seu serviço estratégico, naquilo que é capaz de fazer melhor, com competitividade e maior produtividade.

As tarefas secundárias e auxiliares na atividade de transporte de combustível são realizadas por empresas que se especializaram de maneira mais racional e com menor custo destinando seus ativos para uma atividade principal.

O custo do frete tanto para o reposicionamento do estoque quanto para a distribuição pós venda, é um dos que mais comprometem a margem de lucratividade das organizações principalmente no seguimento de TRR.

E para que as empresas tenha uma margem considerável a busca pelo conhecimento de outras atividades que possa interferir/complementar positivamente no negócio é fundamental.
Neste sentido, o conhecimento pelo fluxo logístico da atividade do etanol veio a favorecer os TRRs com a operação de entrega de diesel em suas bases.

Os TRRs estão utilizando os Transportadores que estão no seguimento de coleta do etanol e em parceria estão pagando somente uma parte do frete a outra parte fica a cargo dos agenciadores compradores do etanol localizado na capital ou outro estado, que por sua vez utilizam o mesmo transportador.

Esta operação fica a carga do transportador, que diante do conhecimento e das informações para montagem de carga elabora a melhor logística possível equalizando distância e tempo para que todos possam ser atendidos e beneficiados.

Para Bertaglia (2010, p. 80) a estratégia de terceirização se baseia em fornecedores que possam gerar uma cadeia de valor, fornecendo para as organizações um custo inferior e com melhor qualidade, reduzindo também os riscos relacionados a estas mudanças, dando tempo maior para as empresas focarem em sua essência do negócio.

O objetivo é comprovar como as parcerias podem ser importantes para as organizações, pois em relação ao seguimento de transporte de combustível a atividade contem custos e peculiaridades para manter as empresas.

Diante disso, os aproveitamentos de frete incorporado com compartilhamento de informações são benéficos para ambos, dessa forma, contribui para melhoria e rentabilidade continua das organizações, para os TRRs incidirá em um Gerenciamento da Cadeia de Suprimentos onde serão destinados todos os processos, recursos e ativos a sua atividade fim, deixando o transporte de reposicionamento de estoque para o parceiro.

\section{EMBASAMENTO TEÓRICO}

\subsection{ATIVIDADE DE TRANSPORTADOR REVENDEDOR E RETALHISTA - TRR}

O transportador-revendedor-retalhista (TRR) é a pessoa jurídica autorizada pela Agencia Nacional de Petróleo (ANP) a exercer a atividade de transporte e de revenda a retalho de combustíveis diesel s10 e s500.

Diferentemente dos postos de combustíveis, esse agente tem como sua principal 
característica realizar vendas a varejo com entrega no domicilio do consumidor.

O segmento de TRR amplia e fornece capilaridade ao abastecimento nacional de combustíveis exclusivamente de diesel.

Os TRRs podem revender para pontos de abastecimento localizados no domicílio do consumidor, na maioria em propriedades rurais e para o abastecimento de máquinas ou de veículos com restrição de locomoção, dificuldades operacionais ou em locais que impossibilitem seu deslocamento.

Esses agentes atendem, por exemplo, ao setor agrícola onde se concentra sua maior distribuição e aos diversos pontos de abastecimento em regiões metropolitanas e no interior do país.

A história dos TRRs, no Brasil, possui mais de um século, e toda evolução é acompanhada pelo sindicato dos TRR (SINDTRR). O início da atividade e revenda de combustíveis com entrega em domicilio data das primeiras décadas do século XX, quando os então denominados peddlers realizavam a entrega de querosene iluminante em pequenas quantidades diretamente nos domicílios dos consumidores.

$\mathrm{Na}$ época, essas empresas atuavam como contratadas das distribuidoras de combustíveis, complementando o abastecimento do mercado.

A partir da década de 1940 a atividade de revenda domiciliar englobou o óleo diesel e os óleos combustíveis e, a partir de 1954, o Conselho Nacional do Petróleo (CNP) reconheceu a atividade na forma em que opera em 2018: empresas que adquirem combustíveis de distribuidores e os comercializam a varejo, realizando o transporte do produto até o cliente final.

\subsection{TRANSPORTE PRÓPRIO DOS TRRS E INÍCIO DAS ATIVIDADES TERCEIRIZADAS}

A frota da empresa é constituída por duas carretas Scania Bitrens com capacidade de carga de 44.000 litros para retirada nas Bases de combustível em Ribeirão Preto e mais 33 caminhões entre 5.000, 10.000 e 15.000 mil litros que fazem a distribuição nas propriedades rurais.

Como as duas carretas bitrens não conseguiria suprir há atual demanda dos TRRs todo excedente, cerca de noventa e cinco por cento foi terceirizado, com isto a ociosidade dos bitrens próprios passaram a desempenhar outra atividade.

Todos os processos administrativos são coordenados para minimizar uma possível ruptura de estoque no TRR, onde os caminhões bitrens são disponibilizados para suprir esta falta devido há peculiaridade das instalações.

No caso dos TRRs seja por parte do Transportador terceirizado que atrasou $\mathrm{o}$ pedido ou houve uma demora na base de carregamento na capital.

Ao tratar deste assunto o autor Chopra (2003) salienta que, ao se tomar decisões sobre investimentos em transporte é necessário considerar os aspectos relacionados à infraestrutura políticas operacionais, a fim de maximizar o retorno sobre ativos da empresa.

Já o autor Bertaglia (2009, p. 80) em relação a este assunto considera que:

Essa estratégia se baseia em fornecedores externos de componentes e de serviços, externalizando certos estágios da cadeia de valor. As vantagens seriam: um fornecimento realizado por um custo inferior e com melhor qualidade [...] essa estratégia pode orientar a organização a reduzir tempos de ciclos, aumentar a velocidade na tomada de decisões, reduzir custos indiretos e concentrar-se na essência do negócio.

Diante disso com o grande aumento na demanda nos TRRs a partir de dezembro de 2014 devido a implementação de novos conceitos gerencias aplicado pela gerencia Geral de Combustível foi necessária à inclusão de parcerias para suprir os gargalos existentes em toda cadeia de suprimentos.

No início dos processos era somente terceirizar o frete $\mathrm{FOB}$ próprio para $\mathrm{FOB}$ terceirizado, e ao decorrer do tempo o departamento de logística em conversas com os motoristas terceirizados identificou-se que esta rota era muito atraente para as empresas transportadoras de combustível, pois ficou evidente o ganho nas duas rotas entrega de Diesel e o retorno com Etanol.

Com o mapeamento das usinas da região produtoras de Etanol, constatou que haveria a possibilidade de redução no valor do frete de entrega de diesel por parte dos transportadores.

E ao incorporar a terceira transportadora a Transportadora Alves Oliveira, atualmente a 
mais ativa e que abriu a realidade de suas informações sobre custos e rotas, as demais passaram a manter seus preços mais baixos para manterem suas rotas operando.

\subsection{LOGÍSTICA DO ETANOL FEITA PELA LOGUM.}

Com a abertura da empresa Logum Logística S.A. que é responsável pela construção e operação do Sistema Logístico de Etanol envolvendo logística de carga, descarga, movimentação e estocagem.

Estendendo-se para operação de portos, terminais terrestres e aquaviários; também para transportes multimodais: dutos, hidrovias (barcaças), rodovias (caminhões-tanques) e cabotagem (navios).

Ela foi criada no dia $1^{\circ}$ de março de 2011 , para ser responsável pela implantação e integração do Sistema Logístico multimodal de transporte e armazenagem de etanol.

A nova empresa é o resultado da integração dos projetos de logística de etanol da Uniduto e Centro Sul ambas coordenadas pela Logum.

Abaixo na figura 1 mostra como esta dividida as operações entre BR e Logum de cada região, na mesma figura a parte em azul identifica o sistema logístico aquaviário, grande oportunidade para o modal rodoviário considerando o escopo do projeto para aproveitamento de frete retorno.

Esta região é a noroeste do estado de São Paulo é grande produtora de etanol, as Usinas que não pertence ao grupo Logum fazem o uso constantes do fluxo logístico por caminhões tanque.

Figura 1 - Rede de coleta e distribuição Logum e BR

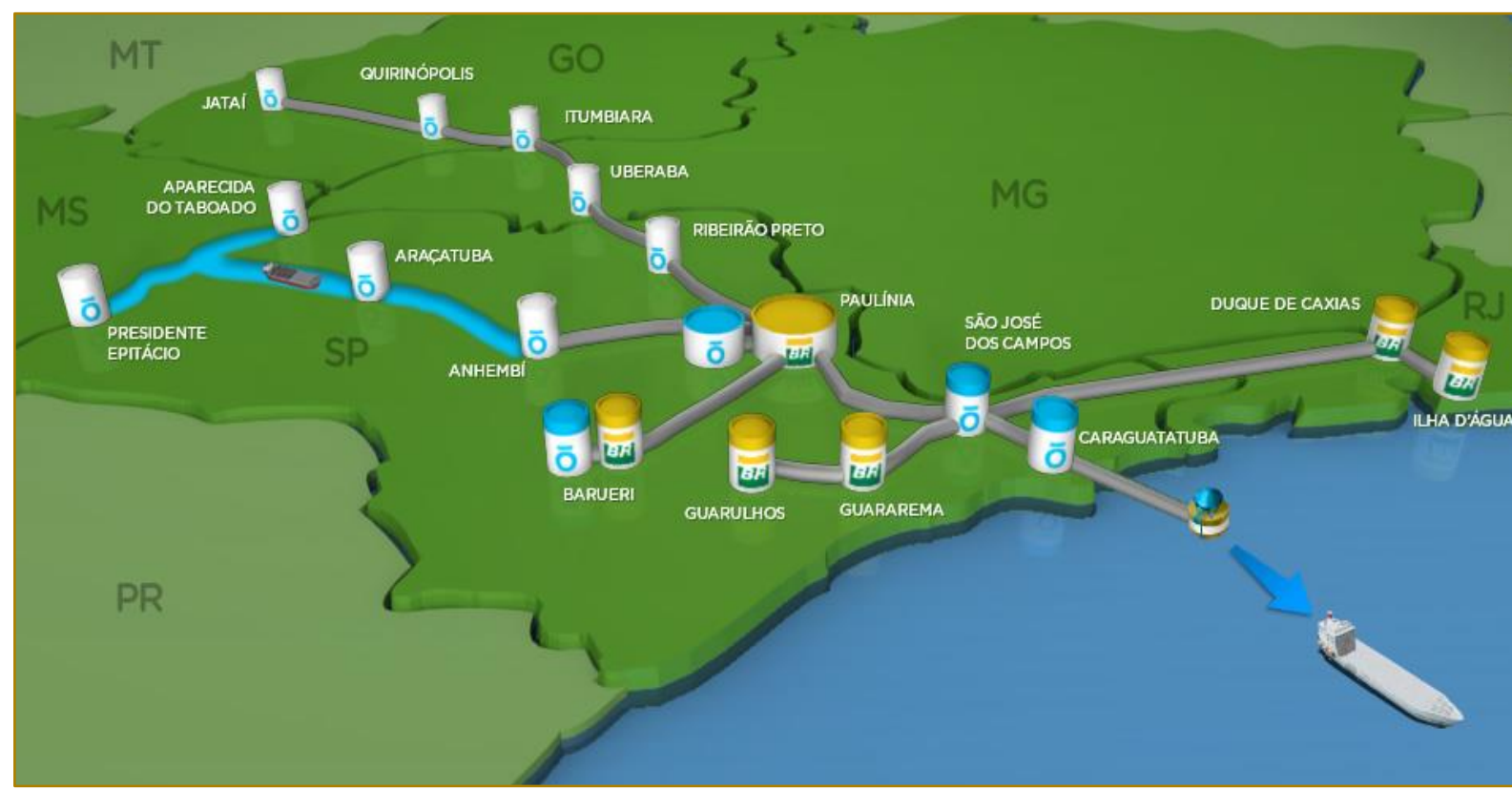

Fonte: Logum Logística S.A.

Porém esta logística é ideal para grandes distâncias onde o preço do bombeamento sempre ficará menor em vista do rodoviário e do ferroviário, além disso, a capacidade de produção das usinas em relação ao escoamento da Logum não suportaria a produção de todo etanol no estado, portanto o rodoviário ainda é extremamente necessário.

Operações paralelas a esta, no seguimento dão continuidade a logística utilizando caminhões tanque como já foi discorrido no caso dos TRRs, também existem outras variáveis que não fazem parte do escopo da empresa Logum.

Outras distribuidoras que tem suas operações independem dos dutoviários e fazem a utilização direta dos transportadores via caminhões tanque para coleta do produto.

Outro ponto fundamental é o tempo que se leva da Usina as Bases revendedoras 
menores como a Royal Fic, Petronac, Potencial Petróleo entre outras que precisam do produto em seus estoques para concluírem a distribuição de seus pedidos.

Ballou (2001, p. 27) afirma que os produtos ou serviços passam a ter valores quando estiverem disponíveis aos clientes no tempo e lugar que eles gostariam de consumir. Portanto, ao movimentar os produtos em direção aos clientes ou disponibilizar estoques no momento oportuno, a logística está criando valores aos clientes este mesmo autor propõe quatro tipos de valores gerados pelas empresas: forma, tempo, lugar e posse.

A forma é o valor gerado pela produção ao transformar a matéria prima em produto, e a posse é o valor gerado ao cliente quando ele adquire o produto.

A logística agrega os valores do tempo e do lugar dos produtos, através das informações, transportes e estoques.

\section{DESENVOLVIMENTO DA TEMÁTICA}

A metodologia utilizada foi a revisão bibliográfica, baseada em livros e sites especializados e também, um estudo de caso entre uma rede de TRR e Transportadoras de Combustível, com o objetivo de verificar a aplicação prática dos conceitos, buscando identificar a necessidade de melhorias na empresa.

\section{RESULTADOS E DISCUSSÃO}

\subsection{COMO O APERFEIÇOAMENTO DA LOGÍSTICA PODE AFETAR OUTRA ATIVIDADE.}

Com a implantação de outra operação logística, paralela ao seguimento pode-se perceber que, o que era antes atendido exclusivamente por caminhões tanque hoje possui um concorrente, como mostra anteriormente as operações da Logum.

A operação de coleta e retorno com aproveitamento de frete é o melhor dos mundos, porém sabemos que, a logística está intrínseca e analisa todos os lados, ou seja, todas as organizações estão a procura da viabilidade e retorno financeiro.
Contudo quando uma das partes começa a ter algum tipo de prejuízo elas tende a ser resiliente, isto pode ocorrer quando um transportador parceiro perde a concessão de coleta do etanol nas usinas da região inviabilizando a operação.

Com esta inviabilidade seu parceiro irá tentar negociar um reajuste no preço do frete, mas como as organizações trabalham com vários parceiros cabe a ela transferir esta rota para outro transportador, a fim de minimizar seu custo com frete.

O mesmo problema pode acontecer quando o TRR muda o local de retirada do diesel, pois o transportador que estiver mais bem localizado terá vantagens sobre a nova rota.

\subsection{ESCOLHA DAS TRANSPORTADORAS TERCEIRIZADAS}

As transportadoras vêm evoluindo cada vez mais e para fornecer integralmente as atividades de transporte tão diversas elas devem conter certificações e sistemas que permitam total controle de segurança, assumindo responsabilidades ambientais, pelo planejamento, programação, coleta, faturamento, rastreamento, treinamento de pessoal, entrega e controle das informações.

A escolha das transportadoras para um TRR dever conter as exigências citada acima e seguir uma lógica na sua localização e nas suas rotas em operação estas analises farão que custos sejam minimizados.

O Transportador escolhido deve ter uma proximidade em relação aos locais de retirada do diesel ou ficar em uma rota que facilite a operação, caso a escolha de uma transportadora fique fora do raio de atuação a mesma irá incorrer um custo adicional no frete encarecendo a operação.

$\mathrm{Na}$ figura 2 a seguir observa-se os pontos pretos desenhados com caminhões mostra a localização das transportadoras parceiras, escolhidas entre os anos de 2015 e 2016.

Nos pontos em laranja mostra as bases de TRR que fazem a redistribuição do diesel adquirido na capital. 
Figura 2 - Localização das Transportadoras

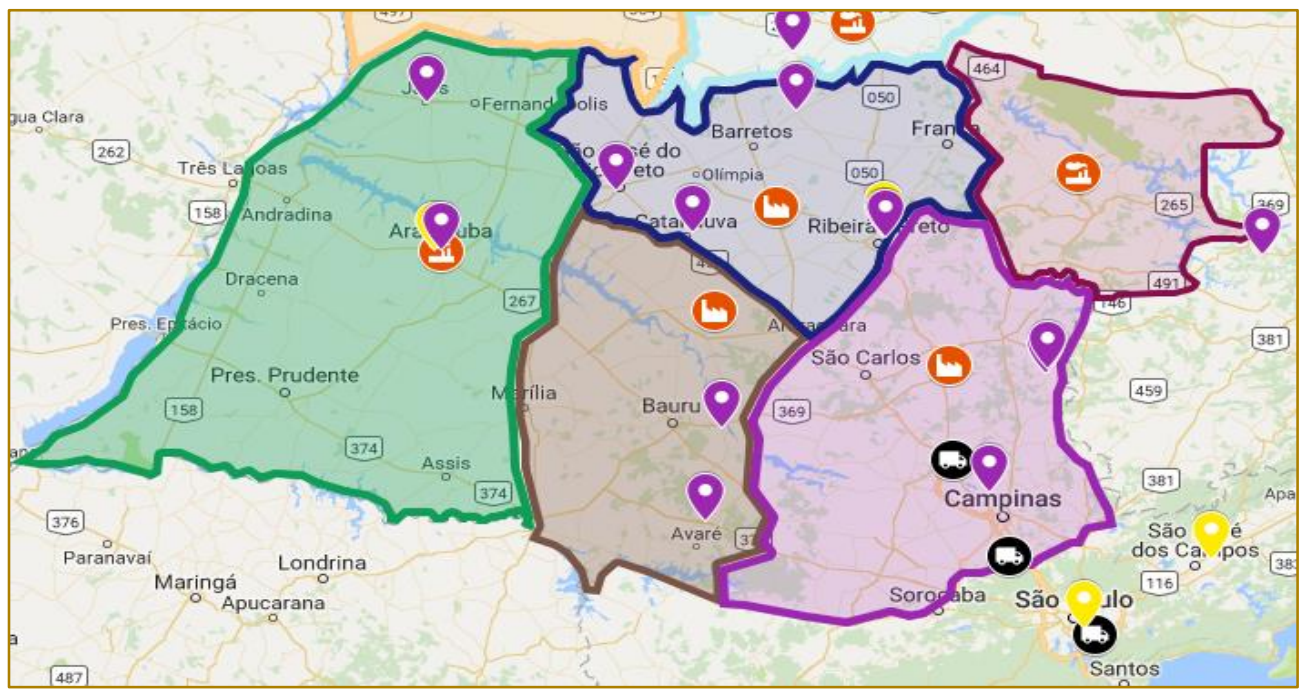

Fonte: Google Maps My Maps

Para Figueira (2001) a terceirização de operações logísticas representa uma grande oportunidade em alguns casos e um considerável risco em outros. Contudo, não analisar devidamente os custos e benefícios dessa terceirização é o maior de todos os riscos.

Este mesmo autor fala que, no altamente competitivo ambiente de negócios, as empresas buscam continuamente melhorar sua eficiência operacional e alcançar vantagens competitivas.

Para Silva (1997) terceirização é a transferência de atividades para prestadores especializados, detentores de tecnologia, frota própria e moderna, que tenham esta atividade terceirizada como sua atividade-fim, liberando a tomadora para concentrar seus esforços gerenciais em seu negócio principal, preservando e evoluindo em qualidade e produtividade, reduzindo custos e ganhando competitividade.

Para a melhor escolha do serviço de transporte análises do departamento de logística deve-se observar as seguintes características:

O preço (custo) do transporte para o embarcador é simplesmente a taxa da linha de transporte dos produtos mais as despesas complementares cobradas por serviços adicionais. O tempo médio e a variabilidade do tempo da entrega estão sempre nos primeiros lugares das relações das mais importantes características de desempenho do transporte. O tempo de entrega (viagem/trânsito é calculado como o tempo médio do percurso de um frete entre origem e destino. A variabilidade diz respeito às diferenças normais que ocorrem entre embarques feitos em modais diferentes. (BALLOU, 2006, p. 151)

\subsection{ROTAS UTILIZADAS PELOS TRANSPORTADORES NO RETORNO DO ETANOL}

As rotas utilizadas pelas transportadoras estão relacionadas onde irão fazer a coleta do etanol, dependendo de qual seja a localização do TRR seja Bebedouro, Pirassununga, Itápolis, Araçatuba ou outros TRR do estado, os transportadores realizam a menor rota possível em relação à Usina a fim de minimizar seus custos.

Esta operação permite que transportadores e TRRs que utilizam esta forma de operação tenham reduções significativas em seus custos operacionais.

É importante salientar que o tempo de retorno para a capital com etanol das usinas é o dobro da ida com diesel para os TRRs, pois no etanol existem variáveis que prejudicam o fluxo da operação e acaba encarecendo um pouco mais a logística tais como:

1) Fila de espera nas usinas para carregamento.

2) As usinas encontram-se em zonas rurais, impossibilitando amparo ao motorista.

3) Liberação de produto por pagamento e qualidade. 
4) Tempo de espera nas Bases de descargas (Base em torno de 1 dia no mínimo).

5) Lei de espera, ou seja, carregar ou descarregar em até cinco horas não aplicada.

\subsection{OBJETIVOS PLANEJAMENTOS E CUSTOS LOGÍSTICOS}

Todo planejamento para uma ação dentro do fluxo de um TRR envolve muitos custos, porém estes devem ser cuidadosamente bem pensados, pois uma falha no processo pode acarretar em perdas financeiras enormes.

Com uma visão da logística de gestão do fluxo, Dornier et al (2000, p. 46) classifica os objetivos logísticos da seguinte forma:

Garantir prazos curtos de entrega, garantir tempos de entrega confiáveis, eliminar inexistência de falta de produtos em estoque, informação logística associada a distribuição de produto, capacidade de consolidação de um pedido e qualidade de transporte.

Já o autor Pozo (2004), ao tratar deste assunto, esclarece que a informação é a função que permitirá o sucesso da ação logística dentro de uma organização de modo que esta possa operar eficientemente, já que todas elas são necessárias para o levantamento de custos, procedimentos, desempenhos e dificuldades encontradas para correto planejamento e controle logístico.

Este mesmo autor conclui que, uma base de dados bem estruturada, com informações importantes sobre o cliente, sobre os volumes de vendas, padrões de entregas, de níveis dos estoques e das disponibilidades físicas e financeiras servirão como base de apoio a uma administração eficiente e eficaz das atividades primárias e de apoio do sistema logístico.

Além disso, para desempenhar todos os processos de um TRR com qualidade e eficiência a um custo mais baixo, Bertaglia (2010) deixa claro que é importante que se conheça todos os custos logísticos que compõem a cadeia de distribuição, como por exemplo, os custos de aquisição e transporte de produtos, recebimento, armazenamento e controle de estoque e, principalmente, com a distribuição.

Para tanto, verifica-se que, na empresa em estudo, isto só será possível através do desenvolvimento de um planejamento logístico, o qual disponibilizará informações e permitirá o controle e gerenciamento sobre a frota, estoques e médias de consumo (demanda), proporcionando maior agilidade e segurança nas rotinas, desde a aquisição do combustível até o abastecimento dos clientes.

\subsection{SISTEMA DE INFORMAÇÕES GERENCIAIS SOBRE CUSTOS}

Para os TRRs prosperar no mercado atual em um cenário político tão difícil é fundamental para sua sobrevivência, e, para isto conhecer a origem dos custos inerentes a sua atividade, como produtos e serviços e, fazer um acompanhamento do desempenho de suas atividades, tornaram-se fatores fundamentais.

Portanto, um sistema de gestão que possa acompanhar a distribuição, realizar o monitoramento dos custos, além de coletar, registrar, processar dados em relação aos fatores de produção, deve ser considerado como um dos fatores críticos de sucesso, deste modo, as informações sobre custos, além de determinar o custo do produto ou serviço, vendido ou prestado pela empresa, podem ser utilizadas para projetar o futuro, por meio do planejamento e controlar as atividades pelos processos de orçamento e avaliação de desempenho (BERTAGLIA, 2010).

Assim, um sistema de custos não terá utilidade se não obter à atenção dos gestores, e, por decorrência, não terão os resultados pretendidos no sentido de auxiliar nas tomadas de decisões.

Portanto, na empresa em questão a elaboração de relatórios de custos devem ser observados alguns fatores, como a objetividade e utilidade das informações, e se faz necessário e urgente que a empresa estruture e adote um sistema de informações gerenciais sobre seus custos logísticos, considerando todo o exposto acima.

\subsection{PEDIDOS DE RETIRADAS PELAS TRANSPORTADORAS NAS BASES DISTRIBUIDORAS}

O processo para inclusão de um pedido para retirada nas distribuidoras deve ser bem sincronizada entre as partes, pois o pedido é lançado no site da distribuidora por um colaborador dos TRRs e posteriormente enviado a um Transportador. 
Bertaglia (2010, p. 197) descreve que quanto mais um pedido a ser atendido estiver em conformidade com os requerimentos, mais o nível de serviço aumentará.

Como todos os transportadores cadastrados possuem acesso e senha, para garantir o cadastramento da placa do veículo no portal e caracterizar a finalização do pedido no site, outras ferramentas de comunicação são utilizadas para garantir a confirmação do pedido como e-mail, telefonemas, e mensagens.

O procedimento de confirmação se faz necessário para garantir que, a transportadora escolhida para o carregamento esteja com um veículo disponível para 0 carregamento nas imediações da capital, seja ela, Transportadora Rodridani, Transportadora Santini ou Transportadora Alves Oliveira.

Devido aos custos com investimento em transporte serem considerados os mais altos, faz com que nossos parceiros tenham preocupações referentes ao tempo de descarga e a roteirização dos veículos para minimização dos custos.

O tempo que as mercadorias passam em trânsito tem reflexos no número de fretes que podem ser feitos por veículo num determinado período de tempo e nos custos integrais do transporte para todos os embarques. Reduzir os custos do transporte e melhorar os serviços ao cliente, descobrir os melhores roteiros para os veículos ao longo de uma rede de rodovias, ferrovias, hidrovias ou rotas de navegação aérea a fim de minimizar os tempos e as distâncias constituem problemas muito frequentes de tomada de decisão (BALLOU, 2006, p. 191).

A transportadora em posse do pedido faz várias análises pertinentes a disponibilidade de veículo e verifica qual veículo estará disponível ou mais próxima a rota para carregamento.

Após todos os processos serem confirmados, assim que o motorista termina o carregamento na Base e retira a nota fiscal o assistente administrativo do TRR já recebe o Documento Auxiliar da Nota Fiscal Eletrônica (DANFE) e sabe que o produto está a caminho.

Com relação ao ciclo de atendimento do pedido, Ballou (2006, p. 192) ensina que:

Os elementos básicos dos serviços ao cliente que o profissional de logística consegue controlar estão dentro do conceito do tempo do ciclo de pedido (ou de serviço). O tempo do ciclo de pedido é definido como o tempo decorrido entre o momento de pedido do cliente, a ordem de compra ou requisição do serviço, e aquele da entrega do produto ou serviço, e aquele da entrega do produto ou serviço ao cliente $\mathrm{O}$ Ciclo do pedido abrange todos os eventos mensuráveis em tempo do prazo total para a entrega de uma encomenda.

\subsection{VERIFICAÇÃO DA DISPONIBILIDADE DE ESTOQUE E SELEÇÃO DO TRANSPORTADOR.}

Após a liberação dos pedidos para formação de carga, acontece simultaneamente, avaliação do nível de estoque, a escolha de qual distribuidora irá comprar o diesel e para qual transportadora que irá fazer a retirada do diesel na distribuidora utilizando a modalidade FOB. Segundo Ballou (2006, p. 189)

A escolha do modal de transporte pode ser usada para criar uma vantagem de serviço competitivo. Quando um comprador na cadeia de suprimentos adquire produtos de mais de um fornecedor, o serviço logístico oferecido e o preço influenciam na escolha do fornecedor.

Este mesmo autor destaca que, para se "incentivar a escolha do mais desejável serviço de transporte, e com isso diminuir seus custos, o comprador oferece ao fornecedor o único atributo que é exclusividade sua - a preferência" (BALLOU, 2006, p. 189).

$\mathrm{O}$ frete CIF (cost, insurance and freight) "custo, seguros e frete" - significa que o frete é pago na origem, ou seja, no preço da venda estão incluídos o custo da mercadoria, o seguro de transporte que garante a mercadoria e o frete de transporte até o destino, porem existe uma peculiaridade que, esta modalidade não pode esperar muito tempo para o descarregamento da mercadoria.

Já o frete FOB (free on board) "livre a bordo" é exatamente o inverso, o frete será pago somente pelo destinatário, ou seja, por conta de quem compra a mercadoria.

O comprador será o encarregado a contratar e pagar pelo transporte, esta modalidade 
permite o interesse mutuo na operacionalização das rotas do etanol.

A negociação com as transportadoras terceirizadas é um ponto favorável, visto que, com estoque pequeno de noventa mil litros (90.000 I) para diesel S-500 e (30.000 I) para diesel S-10 no TRR de Bebedouro e a mesma quantidade para o TRR de Pirassununga já (120.000 I) de S-500 para o TRR de Itápolis os estoques não são suficientes para uma demanda em períodos de safras.
As transportadoras contratadas ao receberem os pedidos de retirada nas distribuidoras, utilizam veículos com capacidade de quarenta e quatro mil (44.000 I) ou cinquenta e oito mil litros (58.000 I) a mais utilizada, que acabam se tornando literalmente um estoque sobre rodas, entre um pedido e outro.

As Figuras 3,4,5 dos caminhões a seguir evidenciam a entrega de 58.000 mil litros de diesel S 500 utilizando veículos rodotrens tanque por transportadores apto para o transporte de combustível.

Figura 3 - Transportadora Rodridani

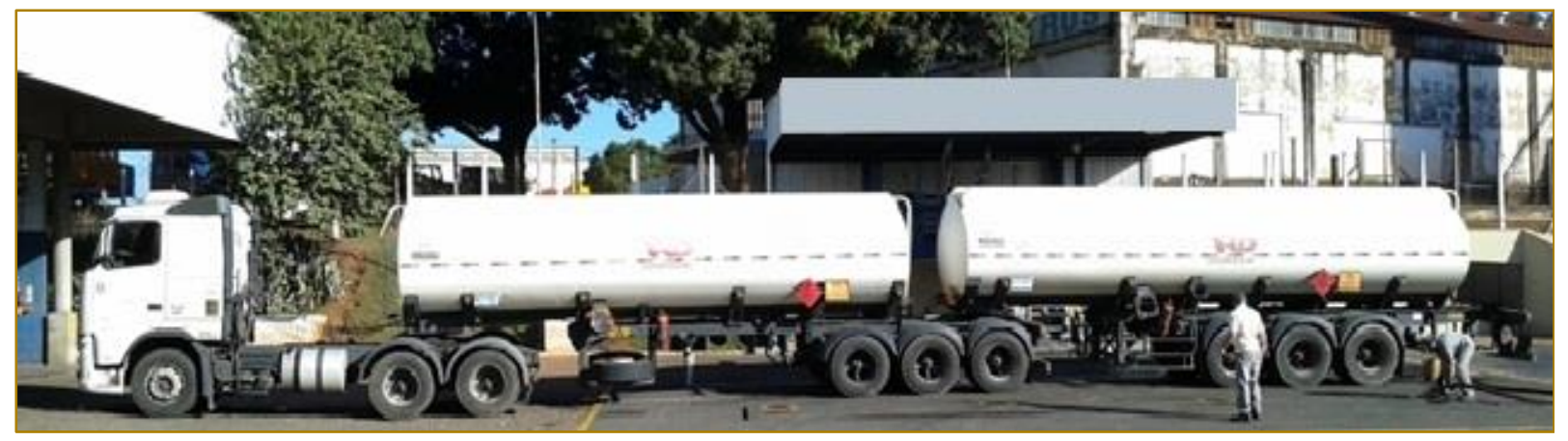

Fonte: Autoria própria

Figura 4 - Transportadora Alves Oliveira

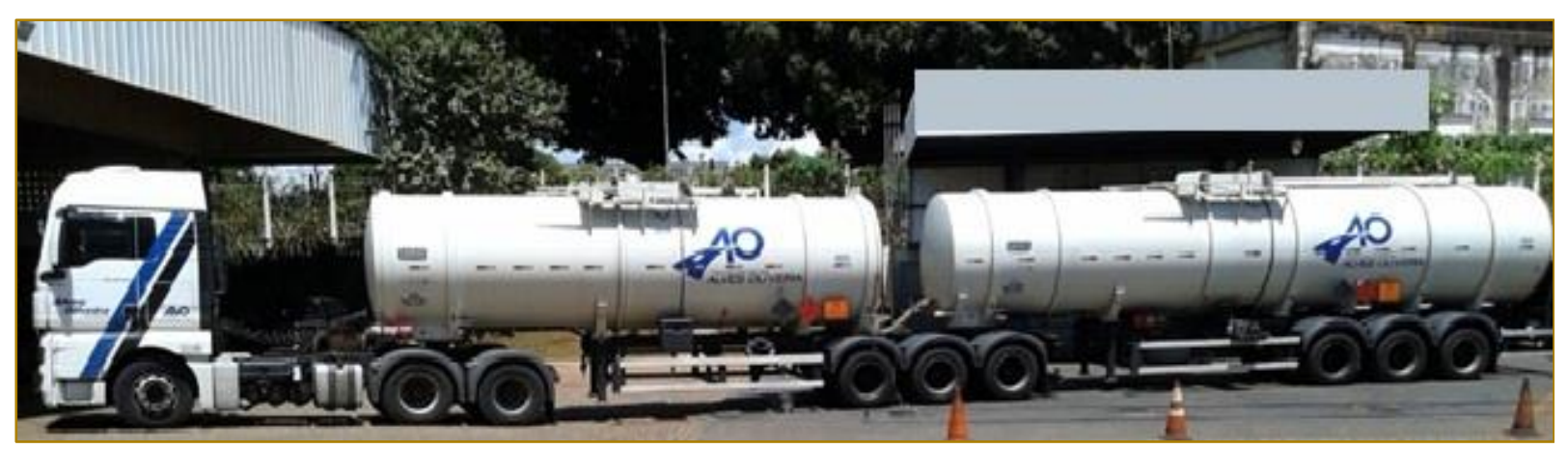

Fonte: Autoria própria

Figura 5 - Transportadora Santini

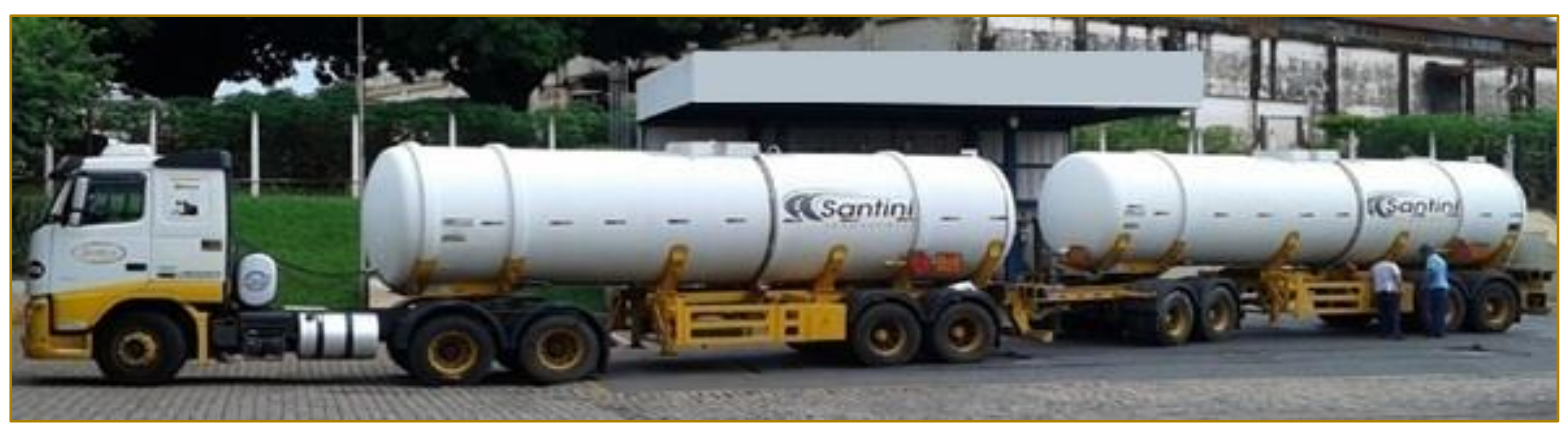

Fonte: Autoria própria 
Nos períodos de safra com o consumo elevado, a solicitação de caminhões acompanha uma logística aonde o recebimento é programado para manhã, tarde e noite, o pode ocorrer de até três caminhões de transportadores diferentes estarem esperando por descarga, porém, isto fica a cargo da transportadora que antecipou o carregamento na distribuidora, devido ociosidade do seu veículo ou adiantou devido outra programação; todo ciclo de programação sincronizada evita que falte 0 produto no estoque do TRR.

Esta negociação gera uma parceria, onde ambos ganham: o TRR com a redução no custo do frete e na aquisição do produto na base distribuidora na Capital, que é mais barata e o transportador, que otimiza sua frota da melhor forma possível.

Nesse contexto ainda os TRRs não precisam imobilizar grandes recursos para aquisição caminhões de grande porte para busca do produto na base, direcionando recursos para

\section{REFERÊNCIAS}

[1]. AXADO. O que é frete CIF e frete FOB? Disponível em: <https://www.axado.com.br/o-quee-frete-cif-e-frete-fob/> Acesso em: 19 abr. 2018.

[2]. BALLOU, R. H. Gerenciamento da cadeia de Suprimentos: Planejamento, Organização e Logística Empresarial. São Paulo: Bookman, 2006.

[3]. BERTAGLIA, P. R. Gerenciamento da Cadeia de Abastecimento. Saraiva 2009.

[4]. CHOPRA, Sunir, MEINDL, Peter. Gerenciamento da cadeia de suprimentos: estratégia, planejamento e operação. São Paulo: Prentice Hall, 2003.

[5]. FARIA, A. Terceirização: um desafio para o movimento sindical. São Paulo: Hucitec,1994. compra de caminhões menores para as entregas em propriedades.

\section{CONSIDERAÇÕES FINAIS}

A partir deste trabalho foi possível analisar que, quando se busca alternativas pela compreensão e entendimento de outra operação logística, no caso do etanol conseguimos extrair um conhecimento que pode ser aplicado na organização gerando assim uma redução no custo do frete e criando uma cadeia de valor.

Portanto este ganho permitiu uma redução significativa que posteriormente os gestores comerciais o repassaram para seus clientes.

Durante todo tempo após as parcerias conclui-se que todas as organizações envolvidas puderam compartilhar os ganhos e acreditar em uma parceria sincera e duradoura.

[6]. FIGUEIRA, Thiago. Quando e como sua empresa deve decidir pela terceirização das operações logísticas. Jan, 2001. Disponível em:<http://www.guialog.com.br/ ARTIG0148.htm> Acesso em: 19 abr. 2018.

[7]. LOGUM. Sistema Logístico php: Disponível em: <http://www.logum.com.br/php/index. php> Acesso em: 19 abr. 2018.

[8]. SILVA, Ciro Pereira da. A Terceirização responsável: modernidade e modismo. São Paulo: LTr, 1997.

[9]. SINDTRR. Quem somos: Disponível em: <https://www.sindisolucoes.com.br/quem-somos> Acesso em: 19 abr. 2018 


\section{Bapítulo 3}

\section{ATIVIDADES LOGÍSTICAS PRIMÁRIAS: ANÁLISE DO PROCESSO LOGISTICO DE DOIS SETORES DA FORÇA AEREA BRASILEIRA-MANAUS}

\section{Henrique Menezes Nogueira}

Wadna Kimberlly da Silva Alves

João Pedro Garcia de Souza

Geisy Anny Venâncio

Resumo: Esta pesquisa teve o objetivo de analisar como os setores de manutenção de aeronaves e suprimento da Força Aérea Brasileira (FAB) executa as atividades primárias da logística. O presente trabalho utiliza-se de informações obtidas através de uma pesquisa bibliográfica e de uma entrevista não estruturada com um militar da FAB. Por meio da entrevista foi possível identificar como é realizado processamento de pedidos e o gerenciamento de estoques nos setores estudados, como também e o modal de transporte utilizado pela FAB-Manaus. Duas das atividades analisadas se dão através do Sistema Integrado de Logística de Material e Serviços - SILOMS, modelo criado com finalidade de unificar os processos logísticos. A utilização do SILOMS proporciona uma agilidade nas atividades logísticas da organização. Dessa forma, é possível ressaltar que a FAB gerencia sua cadeia de suprimento de forma integrada e seu desempenho influencia nos serviços ofertados.

Palavras-chave: Atividades Primárias. Logística. Força Aérea Brasileira. 


\section{INTRODUÇÃO}

A Força Aérea Brasileira (FAB) é o setor aéreo das Forças Armadas do Brasil, cuja missão é defender a nação; garantindo os poderes constitucionais, a lei e a ordem. É de sua competência colaborar com o desenvolvimento nacional e a defesa civil. Para isso, a aeronáutica conta com um acervo de aeronaves e de materiais de alta tecnologia, que exige grande capacitação e planejamento logístico (FORÇA AÉREA BRASILEIRA, 2016).

A Logística da $F A B$ precisa ser exata e objetiva nas suas ações de planejamento. Assim, todas as atividades logísticas devem ser realizadas de forma eficiente e eficaz. Segundo Meirim (2007), essas atividades logísticas são compostas por atividades primárias e de apoio. Sendo as primárias: processamento de pedidos, gerenciamento de estoques e transporte. Para otimizar essas atividades, foi necessário o desenvolvimento de um sistema de informação para dar suporte às operações logísticas. O Processamento de Pedidos, Gerenciamento de Estoques e o Fluxo de Informação da FAB se dão através do SILOMS (Sistema Integrado de Logística de Material e Serviços), modelo criado com a finalidade de unificar os processos de logística.

O processamento de pedidos é uma das etapas primárias do ciclo do pedido do cliente. O desempenho desta etapa influencia diretamente nos custos e desempenho do serviço ofertado ao cliente. Pode-se verificar que um sistema eficaz de Processamento de Pedidos é primordial para o desenvolvimento da organização. (PORSEBON, 2014).

Segundo Coelho (2012) o gerenciamento de estoques refere-se à gestão dos recursos materiais que podem ajudar a organização a gerar receita a longo prazo. Ballou (2001) disserta que mesmo com os avanços da tecnologia, o transporte é primordial para que os processos logísticos sejam finalizados. Muitas empresas procuram na logística de transporte obter um diferencial competitivo. A FAB busca utilizar-se de suas aeronaves.

Neste contexto, foram introduzidos sistemas logísticos e administrativos da cadeia de suprimentos, que resultaram no "Sistema Integrado de Logística de Material e de Serviços" - SILOMS. Diante deste cenário, o presente trabalho é conduzido pela seguinte pergunta: Como a FAB gerencia sua cadeia de suprimento?
Sabendo que a logística busca otimizar o fluxo de informação, este estudo tem como objetivo geral analisar como a FAB-Manaus executa as atividades primárias da logística e, portanto, neste artigo identifica-se como é realizado o processamento de pedido e o gerenciamento de estoques dos setores de manutenção de aeronaves e suprimento da FAB-Manaus, bem como são apontados os modais de transportes utilizados pela organização.

Os dados para este estudo foram coletados por meio de pesquisa bibliográfica e realização de entrevista não estruturada com um militar da FAB que, ao longo deste artigo, será identificado como Militar $\mathrm{X}$.

A seguir, são apresentadas seções a respeito: do embasamento teórico (que trata especificamente sobre três assuntos em questão: processamento de pedidos; gerenciamento de pedidos e modais de transporte); materiais e métodos utilizados para o desenvolvimento da pesquisa; os resultados e e discussões do trabalho; as considerações finais $e$ as referências utilizadas.

\section{EMBASAMENTO TEÓRICO}

Os assuntos abordados nesta seção são referentes às atividades primárias da logística. Os temas estão de acordo com os objetivos do trabalho e serão detalhados a seguir.

\subsection{LOGÍSTICA E ATIVIDADES PRIMÁRIAS}

Santos e Santos (2016) conceituam a logística como um campo da administração, cuja função é otimizar os fluxos de informações e materiais, desde sua origem até seu destino final. Sua finalidade é oferecer melhor desempenho de serviços a menores custos.

Para isso, a logística é constituída por um conjunto de atividades primárias e de apoio, que são ações essenciais para alcance dos objetivos logísticos. As atividades primárias são: transportes, manutenção de estoques e processamento de pedidos (PEREIRA; FERREIRA, 2016). Ao executar essas atividades de forma eficiente, as organizações aprimoram seu nível de serviço logístico. 


\subsection{PROCESSAMENTO DE PEDIDOS}

De acordo com Porsebon (2014) o processamento de pedidos é a atividade que inicia com os processos e atividades logísticas e termina com a entrega do produto ao cliente. Esse processo está incluído no ciclo de pedido do cliente e ocorre após ser realizada a solicitação de um produto à empresa. Segundo Rodrigues (2010) as etapas apresentadas na Figura 1 fazem parte do processamento.

Figura 1 - Ciclo de pedidos

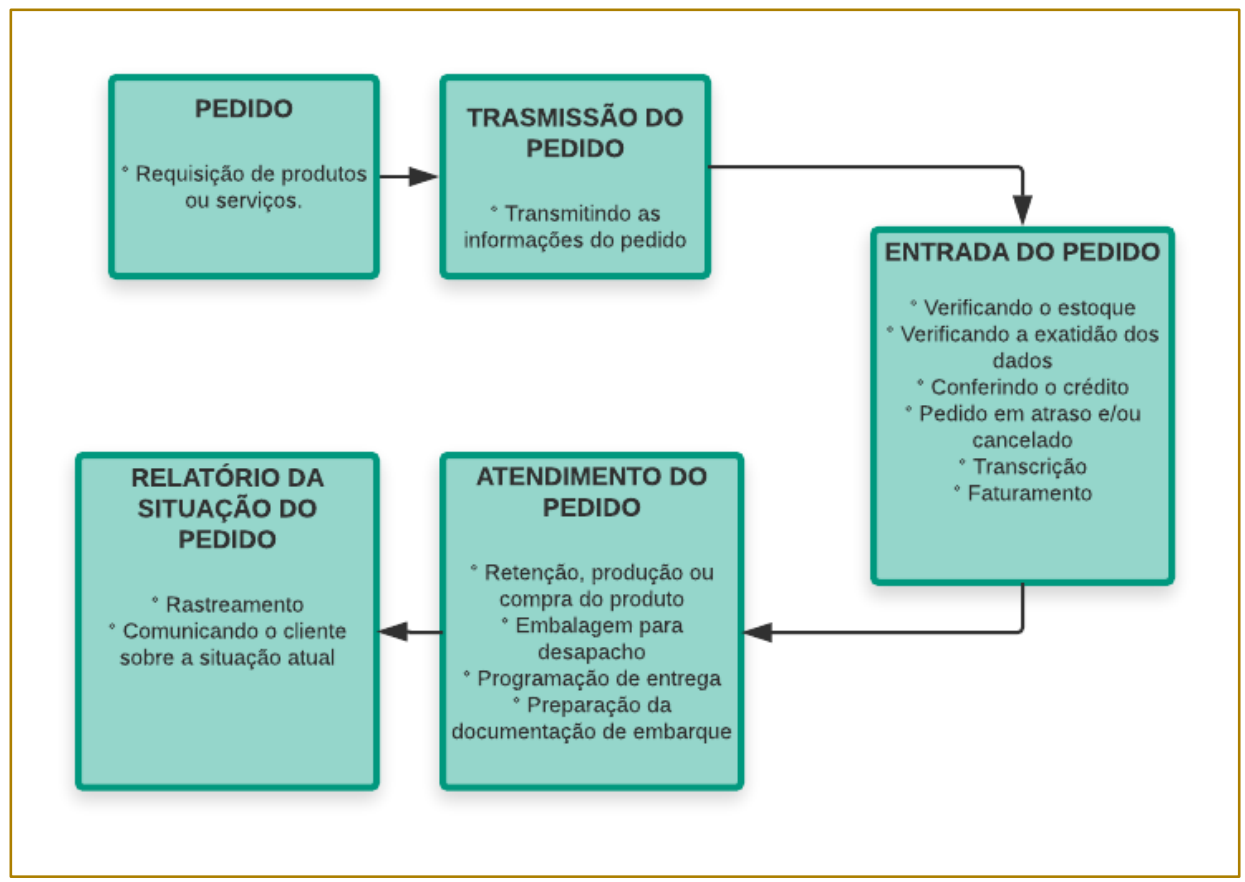

Fonte: Rodrigues (2010).

Segundo Bowersox e Closs (2001) o processamento de pedidos no âmbito empresarial é composto por: criação do pedido, geração da fatura, emissão de documentos para a separação da mercadoria e verificação dos pedidos, verificação da reserva de estoque, processamento do pedido, atendimento do pedido, liberação de estoque reservado, liberação do pedido totalizado e verificação da expedição para entrega em transporte. Já no âmbito militar, de acordo com Gomes (2011) o processamento de pedidos é composto de 5 atividades: preparação, transmissão, recebimento, expedição e relatório do pedido.

Nesses dois sistemas o objetivo e o resultado final são os mesmos, agilidade e qualidade no processo, porém no âmbito militar o processo é representado de forma mais simplificada, já no empresarial apresenta mais etapas, o que não acaba com a viabilidade de nenhum desses sistemas.
De acordo com Rodrigues (2010) o Processamento de Pedidos é uma das três atividades primárias da logística e o tempo despendido nesta atividade pode influenciar diretamente nos custos e níveis de serviço oferecidos ao cliente.

A gestão do Processamento de Pedidos e fluxo de informações é uma das três operações primárias da cadeia logística. O desempenho desta atividade influencia diretamente nos custos e na performance do serviço ofertado pela organização. Com base neste contexto pode-se verificar que um sistema de informação eficaz quanto ao Processamento de Pedidos e o gerenciamento de estoque é primordial para que se possa atingir a competência e competitividade. 


\subsection{GERENCIAMENTO DE ESTOQUES}

O estoque é a composição de materiais em processamento, materiais semiacabados e materiais acabados que não estão sendo utilizados em determinado momento na empresa, mas que precisam ser acondicionados paara eventuais futuras necessidades. (AMARAL; DOURADO, 2011).

A falta de materiais implica em significativos prejuízos para as organizações caso tenham seus sistemas produtivos afetados por isso. $\mathrm{O}$ gerenciamento de estoque consiste em gerir recursos ociosos possuidores de valor econômico e destinados ao suprimento das necessidades futuras de material, numa organização (AMARAL; DOURADO, 2011).

Dessa forma, destaca-se a importância de uma gestão de estoques eficiente nas organizações, visto que o estoque é necessário para garantir o abastecimento de materiais para a empresa, assegurando disponibilidade dos produtos e evitando demora ou atraso no atendimento ao cliente, bem como para garantir a continuidade da produção caso haja eventuais atrasos no fornecimento de materiais, dentre outros fatores relevantes para a manutenção dos estoques (VAGO et al., 2013). Diante disto, é essencial que se tenha um controle total sobre esse estoque..

\subsection{MODAIS DE TRANSPORTE}

Os custos com transporte representam o valor mais significativo quando se fala de custos logísticos. Dessa forma, escolher o modal ideal é essencial para o desempenho da cadeia logística.

Segundo Ballou (2009) a escolha do modal de transporte está relacionada à obtenção de vantagem competitiva quanto a prestação do serviço, pois influencia diretamente o fator custo. Com isso, é necessário analisar características como: preço, tempo de viagem, segurança e confiabilidade. Há uma variedade de serviços à disposição de transporte, girando em torno de cinco modais básicos: hidroviário, ferroviário, rodoviário, aeroviário e dutoviário. Esses podem ser usados em combinação ou é possível utilizar um modal em caráter exclusivo.

No quadro 1 são apresentadas características dos modos de transporte, segundo Ribeiro e Ferreira (2002):

\section{Quadro 1 - Características dos modais de transporte}

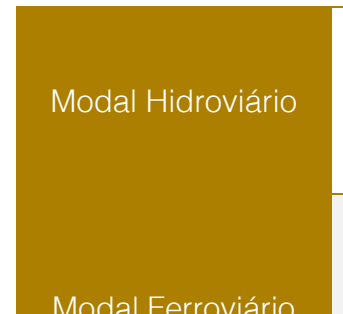

Modal Ferroviário

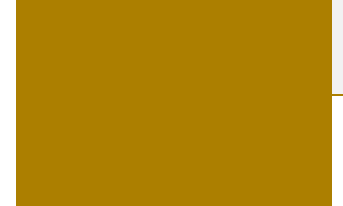

Modal Rodoviário

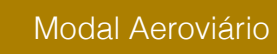

Modal Dutoviário
É utilizado para locomoção em produtos de grandes distâncias, tendo como vantagem principal a sua capacidade de transportar altas toneladas e grandes volumes de mercadorias. A lentidão é tida como uma grande desvantagem no modal hidroviário, visto que, em média, é mais lento que os demais modais.

Seus custos são os de mais baixo valor.

O transporte ferroviário no Brasil é utilizado para o escoamento de produtos como cereais em grão, minérios e produtos derivados do petróleo, que são transportados a granel e em grandes tonelagens. Com relação aos seus custos, este modal apresenta valores baixos, apesar do custo elevado quanto a sua manutenção. O modal ferroviário é capaz de percorrer longas distâncias e com grande quantidade de cargas.

No Brasil é o mais utilizado, pois se destina principalmente ao transporte de produtos acabados e semiacabados em distâncias médias e curtas. Assim, possui preços de fretes superiores em relação aos modais ferroviário e hidroviário. Este tipo de modal é recomendado para transportar mercadorias de alto valor ou perecíveis. Indicado para integração e adequação de tempo de pedidos, assim como a disponibilidade de serviços. Apresenta como desvantagem a capacidade de transportar apenas pequenas cargas.

Este tipo de modal é usado em circunstâncias especiais, tais como transporte de perecíveis e produtos de alto valor unitário. As principais vantagens deste modal são quanto a sua alta confiabilidade e rapidez, além de alcançar de longas distâncias. O transporte aeroviário possui custos elevados quando comparado a outros modais.

É um modal limitado, pois transporta apenas líquidos e gases. Refere-se ao transporte de produtos por dutos subterrâneos. Ele tem como vantagem maior confiabilidade diante dos outros modais, pois possui poucas interrupções.

Como desvantagem está a lentidão na movimentação dos produtos, o que torna inviável para o transporte de perecíveis.

Fonte: Elaboração própria (2018). Com base em Ribeiro e Ferreira (2002). 
Como dito anteriormente, a escolha de cada modal dependerá das características da carga, e também da necessidade da empresa quanto a tempo e gastos com o transporte.

\section{MATERIAIS E MÉTODOS}

A pesquisa tem natureza aplicada e caráter exploratório. De acordo com Gil (2008) as pesquisas de caráter exploratório visam proporcionar maior familiaridade com o tema, no intuito de torná-lo mais explícito. Quanto a abordagem, classifica-se como qualitativa. No que se refere aos procedimentos técnicos adotados, pode ser classificada como bibliográfica e participante (GIL, 2008), uma vez que houve interação entre os pesquisadores e o membro da FAB.

A coleta de dados se deu por meio de uma entrevista não-estruturada com um militar da FAB-Manaus. Na entrevista não-estruturada, segundo Marconi e Lakatos (2007), o entrevistador apenas direciona o entrevistado, permitindo que o mesmo construa a resposta da maneira que the for conveniente. Dessa forma, foram realizadas perguntas abertas sem que houvesse a necessidade de seguir um roteiro rígido, tendo sido estabelecidos tópicos direcionadores com o objetivo de obter informações sobre o problema estudado. A entrevista ocorreu a partir de uma conversação informal, no local escolhido pelo entrevistado. Foi assegurado que a identidade do mesmo seria preservada, por isso o entrevistado está sendo identificado neste trabalho como Militar X.

Tal procedimento foi adotado pela oportunidade de obter dados precisos e que não foram encontrados em fontes documentais. Para garantir maior precisão nos resultados, as respostas foram registradas com o uso de um gravador de voz e depois integralmente transcritas.

Na seção seguinte será exposta a entrevista, com a descrição de como é realizado o processamento do pedido, depois é analisado como ocorre o gerenciamento dos estoques, o modal utilizado pela FAB-Manaus e por último um quadro que resume todas as análises.

\section{RESULTADOS E DISCUSSÃO}

Esta seção é constituída por uma entrevista fornecida pelo militar da Força Aérea Brasileira (Quadro 2), juntamente com as análises das declarações. O Militar X trabalha no setor de manutenção de aeronaves e é um dos responsáveis por realizar pedidos através do Sistema ERP da FAB (SILOMS).

\subsection{ENTREVISTA}

Quadro 2- Entrevista

\begin{tabular}{|c|l|}
\hline \multicolumn{1}{|c|}{ PERGUNTA 1: COMO É REALIZADO O PROCESSAMENTO DO PEDIDO? } \\
\hline $\begin{array}{l}\text { O pedido é feito por um encarregado da manutenção da aeronave. Após detectar a } \\
\text { necessidade de realizar algum serviço, o especialista entra no Sistema Integrado de } \\
\text { Logística de Material e de Serviços (SILOMS), usando seu login e senha, ao entrar, ele cria } \\
\text { uma OS (Ordem de Serviço) onde deve descrever o serviço a ser realizado, salvando-a. Ao } \\
\text { salvar, um número é gerado, esse número é utilizado para acompanhamento. Na própria } \\
\text { OS tem uma aba chamada recursos materiais, que deve ser aberta para cadastro do } \\
\text { pedido de materiais para manutenção. Da mesma forma com a OS, gera-se um número de } \\
\text { pedido que deve ser guardado. No final é impresso um relatório automático com todas as } \\
\text { informações do serviçO. }\end{array}$ \\
\hline PERGUNTA 2: É POSSÍVEL VERIFICAR ESTOQUE DURANTE O PROCESSAMENTO DO PEDIDO? \\
\hline Resposta 2 & $\begin{array}{l}\text { Durante o pedido, é possível saber se o material está disponível, informando o PN (Part } \\
\text { Number). Caso as peças estejam disponíveis no setor de suprimento local, o processo é } \\
\text { rápido. }\end{array}$ \\
\hline PERGUNTA 3: CASO NÃO SE LEMBRE DO PN, O QUE PODE SER FEITO? \\
\hline Resposta 3 & $\begin{array}{l}\text { Na maioria das vezes o PN está localizado na peça ou no equipamento. Ou o mantenedor } \\
\text { pode abrir uma aba pelo próprio SILOMS, na parte do suprimento em consultas e } \\
\text { descrever a nomenclatura, parte dela ou parte do número da peça e pesquisar, assim é } \\
\text { possível checar o PN. }\end{array}$ \\
\hline
\end{tabular}


Quadro 2- Entrevista(continuação...)

\begin{tabular}{|c|c|}
\hline & PERGUNTA 4: DEPOIS DE CADASTRAR O PEDIDO O QUE ACONTECE? \\
\hline Resposta 4 & $\begin{array}{l}\text { Ao fazer o pedido na oficina, chega uma mensagem instantânea no setor de suprimento } \\
\text { local. O suprimentista abre o SILOMS e clica em atender pedido de OS. O sistema abre } \\
\text { uma tela com todos os PN solicitados na OS e a localização dos mesmo no estoque do } \\
\text { suprimento. }\end{array}$ \\
\hline \multicolumn{2}{|r|}{ PERGUNTA 5: COMO É POSSÍVEL SABER A LOCALIZAÇÃO DE CADA MATERIAL? } \\
\hline Respostas 5 & Para isso, todos os PN devem estar cadastrados no estoque. \\
\hline \multicolumn{2}{|r|}{ PERGUNTA 6: APÓS ATENDER À OS, O QUE O SUPRIMENTISTA FAZ? } \\
\hline Resposta 6 & $\begin{array}{l}\text { Se o item solicitado estiver disponível, ele sai do estoque e vai para oficina. O suprimentista } \\
\text { pode levar até a oficina de viatura ou o solicitante pode pegar no balcão. É necessário que } \\
\text { seja impresso um recibo, que é assinado pelo solicitante. Caso não tenha os itens no } \\
\text { estoque, o suprimento solicita transferência do material. Pelo SILOMS, o responsável do } \\
\text { suprimento faz um pedido ao parque de material aeronáutico, gerando um número de } \\
\text { pedido de transferência. }\end{array}$ \\
\hline \multicolumn{2}{|r|}{ PERGUNTA 7: QUAL A AÇÃO DO PARQUE DE MATERIAL AERONÁUTICO? } \\
\hline Resposta 7 & $\begin{array}{l}\text { O parque verifica se tem no estoque e separa o material para a unidade, atendendo ao } \\
\text { pedido de transferência, essa ação gera o número de guia de movimentação de material } \\
\text { (GMM) que aparece na caixa de entrada do suprimento local. No parque também é gerado } \\
\text { um documento físico que viaja junto com o material para o suprimento que solicitante, esse } \\
\text { documento descreve todo o material. }\end{array}$ \\
\hline \multicolumn{2}{|r|}{ PERGUNTA 8: O QUE ACONTECE AO CHEGAR AO SUPRIMENTO? } \\
\hline Resposta 8 & $\begin{array}{l}\text { O material chega na unidade de Manaus por meios aéreos. Ele é entregue para o } \\
\text { suprimentista que confere de acordo com a GMM, se estiver tudo correto, ele assina as } \\
\text { duas vias do documento, uma para o suprimento e outra para o parque. }\end{array}$ \\
\hline \multicolumn{2}{|r|}{ PERGUNTA 9: COMO É A GESTÃO DO ESTOQUE? } \\
\hline Resposta 9 & $\begin{array}{l}\text { Após a chegada de qualquer material, o estoque é alterado, a posição física do material no } \\
\text { estoque deve ser catalogada. Depois, o Sistema é aberto e na caixa de entrada é } \\
\text { confirmada o recebimento, assim ele vai constar no estoque. Nessa parte o local físico } \\
\text { deve ser cadastrado, o que facilita a gestão. Se houver alguma OS aberta, o suprimento } \\
\text { responde ao pedido e distribui os itens. }\end{array}$ \\
\hline
\end{tabular}

Fonte: Elaboração própria (2018).

\section{2 PROCESSAMENTO DE PEDIDOS}

O setor de manutenção de aeronave é responsável pela conservação do acervo de aviões e helicópteros da Força Aérea. Para isso é necessária a prestação de serviços que envolve um outro setor: suprimento. Dessa forma, a partir da comunicação desses setores é possível analisar como ocorre o processamento de pedidos e a gestão de estoque de uma divisão da FAB.

Após identificar a necessidade de um serviço, o setor de manutenção realiza o processamento de pedidos em algumas etapas. Estas etapas foram identificadas e classificadas em cinco, as quais serão descritas no quadro 3. 
Quadro 3- Processamento de pedido (setor de manutenção da FAB-Manaus

\begin{tabular}{|ll} 
ETAPA 1 & \multicolumn{1}{c|}{ Nessa etapa, o responsável pelo serviço cadastra a Ordem de Serviço (OS). } \\
ETAPA 2 & $\begin{array}{l}\text { Durante esta etapa o especialista descreve os serviços que serão realizados, o tempo } \\
\text { previsto para a sua conclusão e a oficina que realizará a manutenção. Nessa etapa é } \\
\text { necessário salvar o registro da solicitação, gerando um número de OS. }\end{array}$ \\
& $\begin{array}{l}\text { Depois de registrar e salvar a OS, inicia-se a terceira etapa. A mesma ocorre quando o } \\
\text { responsável da manutenção requer os materiais que serão utilizados no reparo das } \\
\text { aeronaves. Cada material tem um número, Part Number (PN), que junto com o número da } \\
\text { OS servirão para o acompanhamento do pedido e a verificação da disponibilidade das } \\
\text { peças no estoque. }\end{array}$ \\
ETAPA 3 & $\begin{array}{l}\text { A quarta etapa acontece a partir do recebimento do pedido pelo responsável do setor de } \\
\text { suprimentos, sendo o pedido requerido na OS, conferido e aceito através do sistema } \\
\text { SILOMS. }\end{array}$ \\
ETAPA 4 & $\begin{array}{l}\text { Após a finalização é emitido um relatório, feito de maneira automática pelo próprio sistema, } \\
\text { nele consta todos os dados do serviço }\end{array}$
\end{tabular}

Fonte: Elaboração própria (2018)

Apesar de ter características diferentes, por meio da entrevista é possível evidenciar que o processamento de pedidos dos setores da FAB também é realizado por um ciclo. Este ciclo pode ser correlacionado com o item 2.1 deste trabalho e sintetizado da seguinte forma:

Figura 2 - Ciclo do processamento de pedidos nos setores da FAB-Manaus

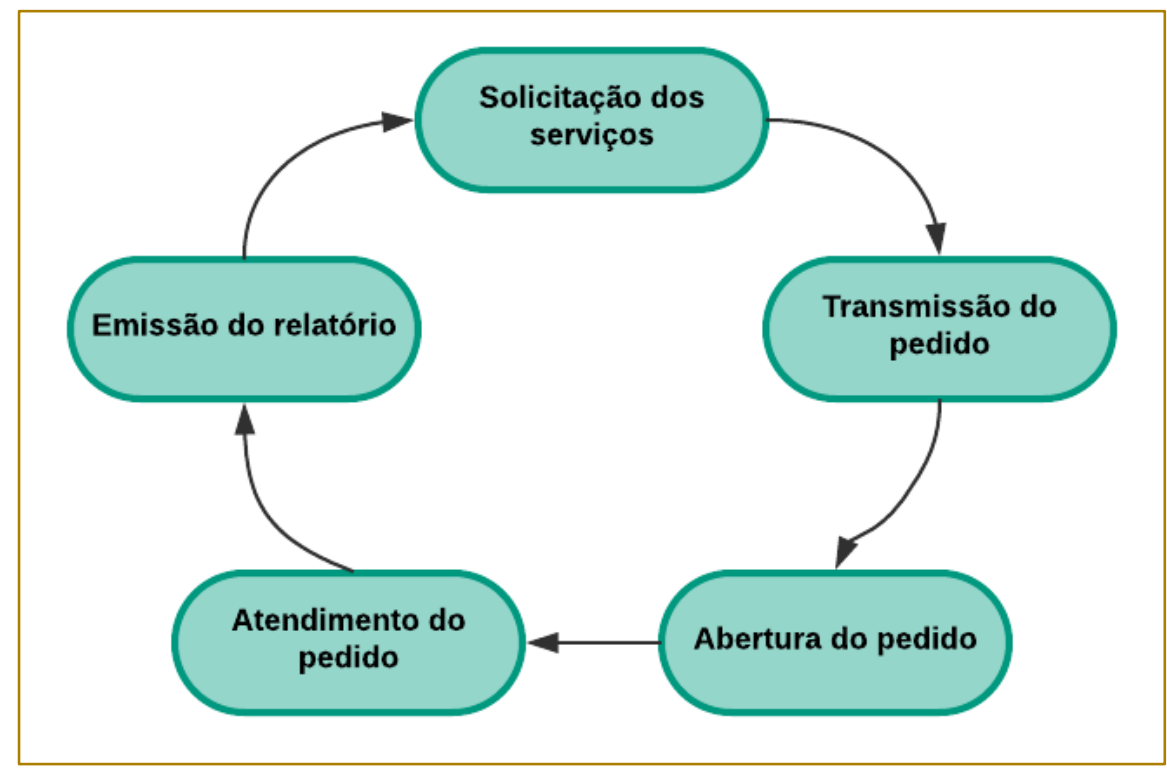

Fonte: Elaboração própria (2018)

\subsection{GERENCIAMENTO DE ESTOQUES}

Para realizar os serviços nas aeronaves são necessários materiais que estão armazenados no suprimento local ou nos parques de material aeronáutico. A gestão dos estoques, a comunicação entre os dois setores e a transferência do parque para o suprimento local são realizadas principalmente pelo SILOMS. Conforme a literatura, o SILOMS pode ser caracterizado como um Enterprise
Resource Planning - Sistema de Gestão Empresarial (ERP), já que integra e gerencia grande parte dos setores da FAB, inclusive os estudados neste trabalho.

Por meio da entrevista é possível comprovar como ocorre o gerenciamento de estoques.

Cada peça possui um número que é devidamente cadastrado no sistema, facilitando a gestão do inventário da FAB. 
"...é possível saber se o material está disponível, informando o PN (Part Number)." (Resposta 2); "...pode abrir uma aba pelo próprio SILOMS, na parte do suprimento em consultas e descrever a nomenclatura, parte dela ou parte do número da peça e pesquisar, assim é possível checar o PN" (Resposta 3); "O suprimentista abre o SILOMS e clica em atender pedido de OS. O sistema abre uma tela com todos os PN solicitados na OS e a localização dos mesmos no estoque do suprimento" (Resposta 4); "...todos os PN devem estar cadastrados no estoque" (Resposta 5); "Após a chegada de qualquer material, o estoque é alterado, a posição física do material no estoque deve ser catalogada. Depois, o Sistema é aberto e na caixa de entrada é confirmada o recebimento, assim ele vai constar no estoque. Nessa parte - local físico deve ser cadastrado, o que facilita a gestão..." (Resposta 9).

A comunicação dos setores também ocorre pelo SILOMS. Quando um pedido é processado o setor de suprimento deve atendê-lo.

"Caso as peças estejam disponíveis no setor de suprimento local, o processo é rápido" (Resposta 2); "Ao fazer o pedido na oficina, chega uma mensagem instantânea no setor de suprimento local." (Resposta 4); "Se o item solicitado estiver disponível, ele sai do estoque e vai para oficina" (Resposta 6).

Caso falte algum material no suprimento local, é possível realizar a transferência de um estoque para outro através do SILOMS.
"Caso não tenha os itens no estoque, o suprimento solicita transferência do material. Pelo SILOMS, o responsável do suprimento faz um pedido ao parque de material aeronáutico..." (Resposta 6); "O parque verifica se tem no estoque e separa o material para a unidade, atendendo ao pedido de transferência..." (Resposta 7).

Pelo discurso do entrevistado é possível analisar como ocorre o gerenciamento de estoque, bem como sua importância para realização dos serviços. Sem um bom gerenciamento dos estoques o setor de manutenção de aeronaves seria atingindo, atrasando serviços importantes, ocasionando problemas com a continuidade das atividades da organização..

\subsection{MODAIS DE TRANSPORTE}

O transporte dos suprimentos e os serviços ocorrem através do modal aeroviário por necessidade da FAB-Manaus quanto a velocidade elevada para o recebimento de materiais e devido às dificuldades logísticas no que se refere ao transporte rodoviário local. As vantagens deste modal são a velocidade elevada, distância alcançada, segurança, redução de custo com estoque.

A seguir é apresentada uma figura que resume as análises realizadas, seguindo a proposta do trabalho.

Quadro 4 - Resumo das análises

\begin{tabular}{|c|c|}
\hline ASSUNTO & ANÁLISE DAS PRÁTICAS DESEMPENHADAS PELA \\
FAB-MANAUS \\
\hline Processamento de pedidos & Realizado por um ciclo de ações \\
\hline Sistema de Informação & SILOMS \\
\hline Gerenciamento de Estoques & $\begin{array}{c}\text { Gerenciado principalmente pelo sistema integrado } \\
\text { utilizado pela organização }\end{array}$ \\
\hline \multicolumn{2}{|c|}{ Modais de Transportes } \\
\hline \multicolumn{2}{|c|}{ Fonte: Elaboração própria (2018). }
\end{tabular}

De acordo com o entrevistado, a implantação do SILOMS proporcionou uma agilidade nas atividades administrativas e logísticas dentro da organização. O resultado das informações armazenadas no sistema intensificou o uso de indicadores, tornando as atividades logísticas mais eficientes e eficazes.

\section{CONSIDERAÇÕES FINAIS}

A gestão do processamento de pedidos, manutenção de estoque e transporte são as três operações primárias da cadeia logística, e o desempenho destas ações influencia diretamente nos custos e serviço ofertado. Neste contexto, pode-se verificar que um sistema eficaz que integre essas atividades é 
primordial para atingir a competência e competitividade.

Neste artigo procurou-se apresentar uma análise de dois setores da Força Aérea Brasileira, tendo como base as três atividades primárias da logística: processamento de pedido; gerenciamento de estoque $e$ transporte. A investigação ocorreu de forma satisfatória e os objetivos propostos foram alcançados. A partir dos resultados é possível apontar que a FAB gerencia sua cadeia de suprimento de forma integralizada. As operações logísticas de processamento de pedido e de gerenciamento dos estoques são realizadas através do Sistema Integrado de Logística de Material e Serviços. A escolha do modal aeroviário se faz necessária para o alcance de uma logística melhor.

\section{REFERÊNCIAS}

[1]. AMARAL, J. T.; DOURADO, L. O. Gestão de estoque. 2011. Lins, SP. Trabalho apresentado no III Encontro Científico e Simpósio de Educação Unisalesiano, Lins, 2011.

[2]. BALLOU, R. H. Gerenciando a Cadeia de Suprimentos: planejamento, organização e logística empresarial. Porto Alegre: Bookman, 2001.

[3]. Gerenciamento da Cadeia de Suprimentos: Logística Empresarial. Porto Alegre: Bookman, 2009.

[4]. BOWERSOX, D.J.; CLOSS, D. J. Logística empresarial: o processo de integração da cadeia de suprimento. São Paulo: Atlas, 2001.

[5]. COELHO, L. C. O que é gestão de estoques? 2012. Disponível em:. Acesso em: 28 abr. 2018.

[6]. FORÇA AÉREA BRASILEIRA - FAB. Concepção Estratégica Força Aérea 100: DCA 1145. 2016. Disponível em: Acesso em: 29 abr. 2018.

[7]. GIL, A. C. Métodos e técnicas de pesquisa social. 6. ed. São Paulo: Atlas, 2008

[8]. GOMES, P. F. O sistema logístico militar: Estudo de caso em um depósito de suprimento. Universidade Federal de Juiz de Fora. Curso de Graduação em Engenharia de Produção. Juiz de Fora 2011

[9]. MARCONI, M. A; LAKATOS, E. M. Metodologia do trabalho científico. $7^{a}$ ed. São Paulo: Atlas, 2007

[10]. MEIRIM, H. As atividades primárias da logística. In: Administradores.com. Artigo de 10 de
Por meio da entrevista foi possível identificar como a FAB-Manaus controla o fluxo de informações e de materiais quando correlacionados às atividades primárias logísticas. Assim, garante maior precisão quanto ao funcionamento das atividades que ocorrem desde o instante que acontece o pedido, até o momento em que o pedido é recebido.

São necessárias mais investigações para determinar como ocorrem esses processos em outros setores. Dessa forma sugere-se o estudo completo quanto ao sistema de informação presente na FAB, bem como sua integração com toda a cadeia logística regional.

julho de 2007. Disponível em: . Acesso em: 28 abr. 2018 .

[11]. MOURA, B. C. Logística: conceitos e tendências. Lisboa: Centro Atlântico, 2006.

[12]. PEREIRA, L. A. G.; FERREIRA, W. R.. Logística de transportes, comercio internacional e fluxos das exportações no Norte de Minas Gerais. Boletim Goiano de Geografia, v. 36, n. 1, p. 67-85, 2016.

[13]. PORSEBON, N. F. Os impactos da adoção do EDI na Cadeia de Suprimentos com foco na relação fornecedor e cliente. 2014. 49 f. Trabalho de Curso (Bacharelado em Engenharia de Produção) - Centro Universitário

[14]. SANTOS, A. B.; SANTOS, J. Q.. O processo logístico como estratégia empresarial: um estudo de caso em uma indústria alimentícia de animais. Revista Formadores, v. 10, n. 1, p. 45, 2017.

[15]. RIBEIRO, P. C. C.; FERREIRA, K. A. Logística e transportes: uma discussão sobre os modais de transporte e o panorama brasileiro. XXII Encontro Nacional de Engenharia de Produção, 2002.

[16]. RODRIGUES, E. F. et al. Logística de preparação e montagem de pedidos: Um estudo sobre a aplicação de sistemas na montagem de pedidos em uma editora de livros em São Paulo. VII SEGeT - Simpósio de Excelência em Gestão e Tecnologia - 2010.

[17]. VAGO, F. R. M. et al. A importância do gerenciamento de estoque por meio da ferramenta curva ABC. Revista Sociais e Humanas, v. 26, n. 3, p. $638-655,2013$ 


\section{Capítulo 4}

\section{O TRANSPORTE DE SANGUE E HEMOCOMPONENTES VIA DRONES}

\section{Aline Yuri Muranaka Yajima}

\section{Nataly de Moraes}

\section{Marília de Souza Santos}

Roberto Giusti

Resumo: A logística que envolve o transporte de materiais biológicos humano, é um fator decisivo que deve garantir e assegurar a preservação e qualidade do material transportado, dado a sua complexibilidade e importância a qual implica a preservação de vidas. Este artigo apresenta uma análise da viabilidade do transporte de materiais através de drones, e por meio deste, trazer a possibilidade do transporte de sangue e hemocomponentes. Os riscos biológicos ao meio ambiente, à saúde humana ou à animais em caso de eventuais falhas no transporte, e o grau de urgência que acompanham as solicitações, são as principais diferenças que envolvem esse tipo de transporte em relação ao transporte de cargas convencionais. Para este estudo, optou-se por realizar uma pesquisa exploratória através de um levantamento bibliográfico, com a análise dos modais mais utilizados, e as condições necessárias para o transporte de sangue via drone. Desta forma, foi possível elaborar um cenário hipotético da utilização deste transporte no Brasil, considerando que há uma série de necessidades a serem atendidas em cada meio de transporte.

Palavras-Chave: Sangue . Drone. Transporte. 


\section{INTRODUÇÃO}

Devido a uma grande complexidade e urgência de transportar uma carga biológica, um estudo imerso neste assunto pode desempenhar um papel importante para a saúde pública desencadeando um avanço no setor de transporte.

Desta maneira, para o transporte de Material Biológico humano, como os fluidos corporais, células, órgãos, tecidos, e em especial o sangue, é necessário atenção de todos os agentes da cadeia logística afim de não haver alteração nos componentes do material durante o transporte. Para evitar eventuais riscos, existem normas elaboradas pela ANVISA a qual visa diminuir os riscos sanitários, manter a integridade e proteger o material transportado, das pessoas e do ambiente. Estas normas englobam o acondicionamento de material biológico humano, o transporte, a armazenagem, a embalagem, as condições sanitárias e os procedimentos em situações que ocorram a exposição do material com algo ou alguém ao longo de cada fase do transporte, deste a coleta até o seu destino final.

A temática deste artigo é abordar um estudo sobre a possibilidade do transporte de sangue e hemocomponentes (crioprecipitado, plasma, concentrado de hemácias, concentrado de plaquetas, glóbulos brancos e vermelhos) entre hospitais e postos de coleta de sangue por meio de drones no Brasil, e os objetivos específicos consiste em, realizar um estudo sobre a utilização de drones para o transporte; identificar as embalagens e acondicionamentos necessários para o transporte correto de materiais biológicos, especialmente o sangue; e, analisar o benefício do transporte de materiais biológicos através de drones.

A discussão travada neste trabalho envolve algumas questões acerca de: Como funciona o drone? Como é feito o transporte de materiais biológicos? Como poderia ser realizado o transporte de sangue em drones? Como seria caso o drone fosse utilizado para o transporte de sangue no Brasil?
Os dados para este estudo foram coletados por meio de uma pesquisa exploratória mediante a um levantamento bibliográfico sobre o tema, assim como, visitas técnicas em postos de coleta de sangue e hemocomponentes a fim de obter maiores explicações, proporcionando melhor compreensão sobre o assunto.

Os textos seguintes, encontram-se organizados em tópicos e subtópicos, e de forma sistêmica é apresentado um resumo sobre: o que é o transporte e os tipos de carga existentes; drones e sua aplicação; riscos biológicos do material, embalagens e acondicionamentos; e a viabilidade do transporte de sangue e hemocomponentes via drones no Brasil.

\section{SANGUE}

Em conjunto com o coração e os vasos sanguíneos, o sangue compõe o sistema circulatório e é produzido na medula óssea vermelha, sendo incumbido de movimentar os nutrientes, gás carbônico e oxigênio para o corpo, composto por células, plaquetas, plasma e glóbulos sanguíneos.

As Plaquetas atuam na prevenção de hemorragias e auxiliam no processo de coagulação e cicatrização de fissuras.

Os glóbulos sanguíneos são divididos em dois tipos:

Glóbulos vermelhos: também chamados hemácias, são os responsáveis por transportar o oxigênio.

Glóbulos Brancos: conhecidos como Leucócitos, tem a função de defesa no corpo.

O plasma é a parte líquida do sangue de coloração amarelada e corresponde a cinquenta e cinco por cento de sua composição total, também é responsável por transportar todos os elementos presentes no sangue, é composto por noventa por cento de água, e cinco por cento por proteínas. 
Figura 1: Sangue centrifugado

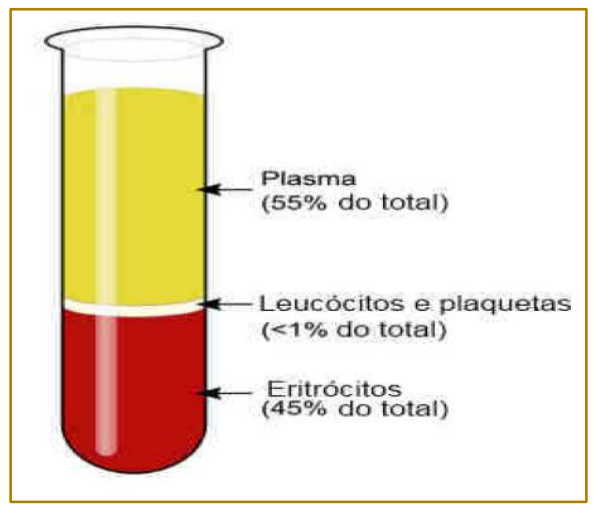

Fonte: Tua Saúde, 2017

\subsection{TRANSPORTE}

Dentro da Logística o serviço de transportes desenvolve um papel importante, tanto na qualidade dos serviços prestados aos clientes quanto na responsabilidade pela maior parcela de despesas relacionados à logística em uma organização.

Para Rodrigues (2007) um sistema de transporte é constituído pelo modo (via de transporte), pela forma (relacionamento entre os vários modos de transporte), pelo meio (elemento transportador) e pelas instalações complementares (terminais de cargas).

Existem cinco tipos básicos de modais para o transporte de cargas.

Rodoviário: aquele feito por caminhões, carretas, bitrens, treminhões que se utilizam da malha rodoviária;

Ferroviário: aquele realizado nas ferrovias por trens, compostos de vagões que são puxados por locomotivas;

Aquaviário: abrange o modo marítimo e hidroviário sendo que o Marítimo é aquele onde a carga é transportada por embarcações, através de mares e oceanos e o Hidroviário, também denominado de fluvial ou lacustre, aquele transportado em embarcações pelos rios, lagos ou lagoas;

Aeroviário: aquele realizado por aeronaves;

Dutoviário: aquele em que os produtos são transportados por meio de dutos.

Estes cinco tipos de modais apresentam suas próprias características operacionais e custos, além de vantagens e desvantagens. Portanto, a escolha da melhor opção de transporte é feita pela análise da natureza e características da mercadoria, tamanho do lote, o tempo de trânsito, disponibilidade e frequência do transporte, o valor do frete, entre outros critérios. Dessa forma, o modal de transporte mais viável será aquele que oferecer uma entrega na porta do cliente a um menor custo, em um tempo adequado, buscando, portanto um melhor equilíbrio na relação preço/serviço.

Abaixo segue a definição de um novo meio de transporte que vem ganhando espaço no mercado nos últimos anos pelo seu baixo custo, rapidez, facilidade e agilidade. Esta nova modalidade de transporte é conhecido como Drones.

\subsection{DRONES}

Começaram a ser desenvolvidos em 1960, entretanto, por seus usos militares, ganharam destaque em 1980. No início os drones eram utilizados como equipamento de diversão para filmagens e fotos, e se tornaram equipamento primordial ganhando espaço nas áreas comerciais. São conhecidos como Veículo Aéreo Não Tripulado (AVANT), ou seja, aeronaves controladas remotamente, que são preparados para voar de forma autônoma. .

Com os avanços tecnológicos, empresas como a norte-americana Amazon vem, desde 2013, realizando testes nas entregas de seus produtos em um prazo médio de 30 minutos através de um sistema que utiliza drone, intitulado Prime Air. Estas entregas serão realizadas em uma altitude de 200 a 500 pés, ou seja, aproximadamente de 61 a 152 metros de altura, de forma que não haja colisão entre o veículo não tripulado e os prédios, postes e torres, tal como, a altitude 
não venha interferir nas atividades do espaço aéreo nacional. Os drones que estão sendo testados pela empresa Amazon podem viajar a 100 quilômetros por hora, com cargas de até 25 quilos, e com autonomia de 150 quilômetros de distância, também são equipados com sensores que detectam automaticamente qualquer obstáculo no percurso, impedindo colisões.

De acordo com a matéria publicada pela revista Época Negócios (2017), a empresa Matternet com sede na Suíça, já vêm utilizando os drones para serviços na área da saúde, transportando materiais emergenciais como bolsas de sangue e seus hemocomponentes, amostras, medicamentos e vacinas, através de um sistema autônomo a qual permite a decolagem, o vôo, e a aterrissagem sem a ajuda de um profissional treinado para esta tarefa. A empresa tem como objetivo, conectar os laboratórios e hospitais em todas as cidades do país.

A grande dificuldade de acesso a países não desenvolvidos com infraestrutura precária, tem atraído olhares de organizações como a Zipline, uma empresa norte- americana, e o Órgão Fundo das Nações Unidas para a Infância (UNICEF) que vem realizando entregas de medicamentos, amostras de sangue e vacinas em áreas de difícil acesso no continente africano, em países como a Ruanda.

A Zipline, iniciou suas atividades na Ruanda em 2016, distribuindo sangue, plasma e plaquetas para vinte e um hospitais, sendo realizadas entregas via drones, que são monitoradas remotamente. Em uma entrega que tem origem no centro de distribuição no distrito de Muhanga, localizado a 50 quilômetros da Capital do país, Kigali, o trajeto caso realizado pelo modal rodoviário levaria aproximadamente quatro horas, e o mesmo trajeto por drone, leva em média trinta minutos.

No Brasil existem regras para o uso do drones. Segundo o Ministério dos Transportes, Portos e Aviação Civil (MTPA), todo e qualquer objeto que se desprenda do chão e seja capaz de se sustentar na atmosfera está sujeito às regras de acesso ao espaço aéreo brasileiro. Deste modo, todo vôo com aeronave não tripulada também precisa de autorização.

As regras para drones, segundo a própria Agência Nacional de Aviação Civil (Anac), são complementares aos normativos do Departamento de Controle do Espaço Aéreo (Decea) e da Agência Nacional de Telecomunicações (Anatel).

O drone a ser utilizado no Brasil seria o mesmo que está em teste na empresa Amazon, com capacidade de transportar até 25 quilos a quase 100 quilômetros por hora, utilizando as caixas térmicas com a capacidade 10 litros que pesam cerca de 1,6 quilos, com termômetro para adequar a temperatura dos hemocomponentes e gelo termogel não tóxico, reutilizável e que mantém a temperatura do material por mais tempo que o gelo comum.

As regiões que serão atendidas devem estar em até 94 quilômetros de distância do posto de coleta Clínicas. Nestas condições o prazo para a entrega seria de aproximadamente 57 minutos, levando em consideração a velocidade média de 100 quilômetros por hora.

Segue uma simulação de entrega realizado pelo modal rodoviário partindo do posto das clínicas até o hospital Sapopemba que é um dos receptores: 
Figura 2 - Trajeto do posto de coleta até o hospital receptor Sapopemba no modal rodoviário.

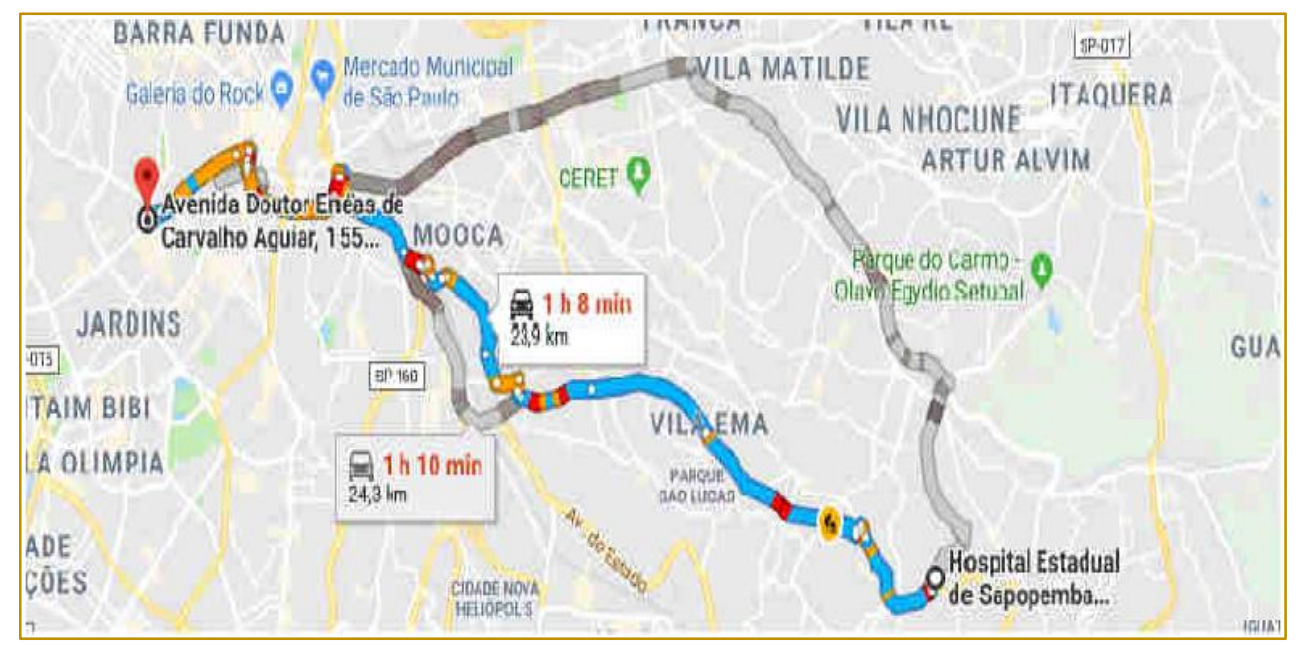

Fonte: Google Maps

Realizando esse trajeto com a distância de 24 quilômetros, um carro levaria em média 1 hora e 10 minutos. Uma entrega para o mesmo local realizada via drone, levaria aproximadamente 15 minutos, sendo assim, o transporte seria otimizado. Com os drones, gastos com o motorista, pedágio, combustível e perda de tempo em trânsito, não existiriam. Os drones prometem uma revolução tecnológica no setor de logística.

\subsection{TIPOS DE CARGA}

O conceito de carga é definido como, tudo aquilo que pode ser transportado ou suportado por pessoas, animais, veículos, aparelhos, estruturas, entre outros. "A carga, em regra, é composta de mercadorias protegidas por embalagem apropriada, se for o caso, de modo que fiquem prontas para o transporte." (FIESP, 2016)

$\mathrm{Na}$ identificação das características da carga devemos observar aspectos como: perecibilidade, fragilidade, periculosidade, dimensões e pesos considerados especiais.

Conforme Vieira (2007) a partir do século $X X$, devido à existência de uma maior quantidade e diversidade de cargas a serem transportadas, se verificou uma divisão dos grupos de carga. As cargas são transportadas de acordo com sua natureza que podem ser:

Carga Frigorificada: são cargas que precisam de refrigeração para congelamento, de forma que as qualidades essenciais do produto sejam mantidas durante o transporte (exemplos: frutas frescas, pescados, carnes, etc.);

Carga Perigosa: aquela que, por causa de sua natureza, pode provocar acidentes, danificar outras cargas ou os meios de transporte ou, ainda, gerar riscos para as pessoas. É dividida pelo IMCO (Organização Marítima Consultiva Internacional) segundo as seguintes classes: | - Explosivos, II - gases, III - líquidos inflamáveis, IV - sólidos

Cargas Vivas: compõe-se de transporte de animais como, o gado, eqüino, asinino, suíno, ovino e caprino. Os veículos devem ser apropriados para manter a integridade física e as condições sanitárias dos animais transportados.

Cargas Biológicas: De acordo com a RESOLUÇÃO - RDC no 20, de 10 de Abril de 2014 a classificação do material biológico humano se define em:

Material biológico humano: tecido ou fluido constituinte do organismo humano, tais como excrementos, fluidos corporais, células, tecidos, órgãos ou outros fluidos de origem humana ou isolados a partir destes.

A $2^{\mathfrak{a}}$ edição do Manual de Vigilância Sanitária para o Transporte de Sangue e Componentes no Âmbito da Hemoterapia (2016, p.06) corrobora: caso este material biológico contiver substâncias infecciosas ou for capaz de alastrar doenças em pessoas ou animais mediante a exposição a elas, deve ser classificado também como material perigoso. 
Portanto, a partir da definição dada pela RESOLUÇÃO - RDC no 20, o Sangue é considerado um material biológico, e para um transporte seguro e adequado a este material biológico, implica em uma série de leis e normas técnicas regulamentadas pelo Ministério da Saúde e pelo Sistema Nacional de Sangue, Componentes e Derivados (SINASAN) a qual modela e estabelece os padrões sanitários fazendo-se necessário o licenciamento cedido pela Agência Nacional de Vigilância Sanitária (ANVISA), que visam minimizar os riscos sanitários e preservar a integridade do material transportado, isto inclui o acondicionamento do material biológico humano, o transporte, a armazenagem, a embalagem, as condições sanitárias, e, também, os procedimentos adequados em casos de exposição do material com algo ou alguém visando à proteção do material, das pessoas e do ambiente durante todas as etapas do transporte até o seu destino final.

Considerando que o sangue e hemocomponentes são materiais perecíveis e que exigem cuidados específicos, as atividades relacionadas ao acondicionamento e controle de temperatura são de extrema importância para manter a conservação e qualidade do produto durante o transporte, pois a mudança de temperatura pode modificar as substâncias contidas no material coletado e ocasionar um resultado oposto ao que fora proposto. Caso os materiais forem submetidos a estas mudanças, devem ser descartados de acordo com a ANVISA, fazendo-se necessário a reposição do material, o que ocasionaria atrasos nas demais atividades logísticas e consequentemente atingiria 0 consumidor final, o que pode ser, eventualmente, um indivíduo que necessita do material com extrema urgência.

Em todas as etapas que envolvem a movimentação do material biológico, um fator que não pode passar despercebido é a classificação do risco biológico que o produto apresenta, é levado em consideração que pode tratar-se de material contaminado e que o contato com o mesmo pode causar infecções tanto em humanos como em animais.

Os riscos biológicos do sangue podem ser classificados de acordo com a Organização Mundial da Saúde OMS, em três categorias A, B e Espécime Humana de Risco Mínimo, relativos à sua facilidade ou não de transmissão de doenças. Na categoria A, O material biológico é infeccioso e sua exposição a seres humanos ou animais pode causar enfermidades mortais. $\mathrm{Na}$ categoria $B$, são amostras que se sabe ou se suspeita conter agentes infecciosos que causam doenças em humanos. $\mathrm{Na}$ categoria Espécie Humana de Risco Mínimo, as amostras que tem pequena probabilidade de agentes infecciosos.

\section{RESULTADOS E DISCUSSÃO}

Prometendo ser mais um avanço tecnológico, os drones que já são utilizados para diversão, estão sendo desenvolvidos para agilizar as entregas de pequenas encomendas, que no caso de transporte de materiais biológicos não beneficiaria somente a área de logística, mas ajudaria diretamente a saúde pública, chegando a locais de difícil acesso.

A proposta é que os drones realizem o transporte após o sangue ou hemocomponentes ter sido coletado, levado ao laboratório para análise e ser devidamente identificado com dados como: nome do responsável pelo envio, o nome do destinatário, telefone para contato de ambos, e data de validade. Posteriormente é acondicionado em uma caixa isotérmica, e distribuído atendendo às solicitações médicas ao hemocentro.

\section{CONSIDERAÇÕES FINAIS}

Este artigo fornece uma estrutura para a exploração de tema de transporte via drone e poderá servir de base para futuros estudos relacionados a este tema.

Os resultados deste estudo demonstram que se aprovado, o transporte de sangue por meio de drones, pode favorecer a sociedade de forma que localidades de difícil acesso possam ser atingidas em um prazo de tempo melhor do que por qualquer outro meio de transporte, considerando o fator de urgência dos pedidos, como já constatado em outros países.

Uma limitação desse estudo é em relação aos custos dos drones, que por tratar-se de um equipamento profissional que ainda é novidade nesta área de atuação, em fase de testes, fabricado por empresas no exterior, a publicação de valores ainda é restrita, não divulgada. 
Uma implicação para a viabilidade e implantação do drone como modal de transporte, pode surgir por parte da legislação brasileira, sugere-se portanto, um estudo futuro mais aplicado à legislação.

\section{REFERÊNCIAS}

[1]. A.C.CAMARGO CANCER CENTER. Composição do sangue. Disponível em: <http://www.accamargo.org.br/saude-

prevencao/infograficos/tudo-sobre-o- sangue/191/>. Acesso em: 02 mar. 2018.

[2]. BBC BRASIL. Ruanda testa drones para envio de sangue, plasma e coagulantes a hospitais em zonas rurais. Disponível em: <http://www.bbc.com/portuguese/internacional37685934>. Acesso em: 17 mar. 2018.

[3]. FOLHAWEB. Conheça as novas regras para drones, aeromodelos e balões. Disponívelem: <http://www.folhabv.com.br/noticia/conheca-asnovas-regras-para- drones--aeromodelos-ebaloes/28798 >. Acesso em: 28 fev. 2018.

[4]. FIESP - Federal das Indústrias do Estado de São. Natureza da carga. Disponível em: $<$ http://www.fiesp.com.br/transporte-elogistica/natureza-de-carga>. Acesso em: $07 \mathrm{fev}$. 2018. [5]. HEMOCENTRO RP. Dúvidas e perguntas.
Disponível em: Disponível <http://www.hemocentro.fmrp.usp.br/canal-dodoador/duvidas-e-perguntas/>. Acesso em: 09 mar. 2018.

[6]. HEMOCENTRO SÃO LUCAS. Ciclo da sangue. Disponível em: $<$ https://www.hemocentrosaolucas.com.br/ciclo-dosangue>. Acesso em: 05 mar. 2018.

[7]. ISTOÉ. Drones são autônomos e têm vantagem competitiva, diz criadora da matternet. Disponível em: <https://istoe.com.br/drones-saoautonomos-e-tem- vantagem-competitiva-dizcriadora-da-matternet/>. Acesso em: 01 fev. 2018.

[8]. O IETEC. Tipos de modais. Disponível em: <http://www.ietec.com.br/imprensa/tipos-demodais-2/>. Acesso em: 01 mar. 2018.
Este artigo, procurou demonstrar a utilização da tecnologia em favor do ser humano, como propõe o slogan "São voos que salvarão vidas!".

[9]. OLHAR DIGITAL. Drones da amazon levam produtos de até $25 \mathrm{~kg}$ a quase $100 \mathrm{~km} / \mathrm{h}$. Disponível em: <https://olhardigital.com.br/pro/noticia/drones-daamazon- levam-produtos-de-ate-25-kg-a-quase100-km-h/47654>. Acesso em: 30 mar. 2018.

[10]. RODRIGUES, P. R. A. Introdução aos Sistemas de Transporte no Brasil e à Logística Internacional. 4를 ed. São Paulo: Aduaneiras, 2007.

[11]. TECHTUDO. Entenda a diferença entre drone e vant e suas aplicações práticas. Disponível em:

$<$ http://www.techtudo.com.br/noticias/noticia/2015/ 05/entenda- diferenca-entre-drone-e-vant-e-suasaplicacoes-praticas.html>. Acesso em: 05 mar. 2018.

[12]. UOL NOTÍCIAS. Entrega de sangue e proteção de civis: como drones ajudam a salvar vidas.. Disponível em: $<$ https://noticias.bol.uol.com.br/ultimasnoticias/internacional/2017/08/20/entrega-desangue-e-protecao-de-civis-como- drones-ajudama-salvar-vidas.htm>. Acesso em: 08 mar. 2018.

[13]. VIEIRA, G. B. B. Transporte Internacional de Cargas. 02ª Ed, São Paulo: Aduaneiras, 2007.

[14]. RODRIGUES, P. R. A. Introdução aos Sistemas de Transporte no Brasil e à Logística Internacional. 4ํㅡㄹ ed. São Paulo: Aduaneiras, 2007.

[15]. VIP CEO. Como drones poderão influenciar os e-commerces e empresas de logística - idg. Disponível em: <https://vipceo.com.br/comodrones-poderao- influenciar-os-e-commerces-eempresas-de-logistica-idg-now/>. Acesso em: 29 fev. 2018.

[16]. ZIPLINE. Entregas de salvamento por drone. Disponível em: <http://www.flyzipline.com/service/>. Acesso em: 12 mar. 2018. 


\section{Capítulo 5}

\section{PROPOSTA DE IMPLANTAÇÃO DO SISTEMA RFID PARA REDUCÃO DE CUSTOS OPERACIONAIS: ESTUDO DE CASO DE UM HOME CENTER AUTOSSERVICO COMO MÉTODO DE VENDA}

\section{Rodrigo dos Santos Kelch \\ Sueli Ferreira Colona \\ Lucas Santos da Costa \\ Enio Fernandes Rodrigues}

Resumo: Diante de um cenário de instabilidade econômica, as empresas procuram minimizar seus custos, pois têm suas margens de lucro reduzidas. Dessa forma, este estudo buscou atingir o objetivo de redução dos custos operacionais, através da implantação de um sistema simples de rádio frequência, que melhor controlasse o estoque de um Home Center, onde haviam perdas não identificadas. O método utilizado para a realização desta pesquisa foi o de estudo de caso, embasado em bibliografias clássicas e artigos científicos, pela confiabilidade que proporcionam. Após o levantamento do problema de pesquisa, por meio de uma empresa especializada, que orçou o sistema e por pesquisa realizada em outro estudo similar, conclui-se que a redução dos custos com a implantação do RFID ficaria em torno de $30 \%$. Esse é o principal resultado do estudo. Foi realizada também a análise econômico-financeira do investimento, por meio de payback, que demonstrou que os custos seriam deduzidos em aproximadamente 20 meses, somente partir daí, a empresa começaria a obter lucro. O presente artigo, com a proposta de implantação do sistema RFID, teve como contribuição um melhor controle dos itens de estoque fisicamente, principalmente os considerados críticos pela empresa case.

Palavras-chave: Estoque. RFID. Redução de Custos. 


\section{INTRODUÇÃO}

O atual cenário de instabilidade política e econômica pelo qual o Brasil passa, faz com que fique mais evidente a realidade do país, que é preciso buscar um nível de eficiência e produtividade cada vez maior, para que o mesmo possa se tornar competitivo. Tal fato se reflete em várias atividades econômicas como na indústria, no comércio e na cadeia de atuação de qualquer segmento do varejo, já que as margens de lucro deste segmento, estão cada vez mais apertadas e sob uma pressão maior por conta da recessão econômica, gerada pelo referido cenário brasileiro.

As empresas, diante deste contexto, procuram formas de reduzir os custos e aumentar a produtividade, através de novas ferramentas e métodos. A Gestão de Tecnologia então passa a ter importância, principalmente no mercado de varejo, onde se estima que as empresas deste setor invistam um percentual considerável de seu orçamento em Tecnologia da Informação e Comunicação aplicada à logística e que o retorno deste investimento depende da realidade de cada empresa e do segmento em que atuam.

Uma das tecnologias cujo uso tem crescido no segmento de varejo é o de Identificação por Rádio Frequência (RFID). A sigla em inglês vem de Radio- Frequency Identification, pois o segmento de varejo, principalmente o de construção é um dos que mais apresentam problemas de perdas e avarias em seus estoques, requerendo formas de controle que tragam maior acuracidade em seus inventários. Neste sentido, a tecnologia de Identificação por Radiofrequência (RFID), utiliza ondas de rádio para identificar objetos, quando utilizada para contagem de estoques, é precisa e não necessita de interferência manual no processo, o que reduz tempo de processamento, erros humanos, avarias por manuseio, e, consequentemente, os custos operacionais.

Dessa forma, a empresa objeto de estudo, é um Home Center localizado na cidade de Guarulhos, sendo um típico exemplo das lojas de redes de varejo que sofrem com os elevados custos operacionais decorrentes das perdas e avarias em seus estoques.

O presente estudo avalia a implantação do sistema RFID no estoque de itens críticos deste Home Center, que representam os produtos que estão mais propensos a furtos ou avarias, devido as suas pequenas dimensões e/ou alto valor agregado. Assim, a importância deste estudo está em reduzir os custos de operação do Home Center, através da proposta de implantação do sistema de RFID, fazendo com que a empresa seja capaz de superar as dificuldades da recessão econômica brasileira, aumentando sua eficiência nas operações de movimentação e controle de estoque, que resultará no aumento das suas margens de lucro e, por consequência, na manutenção da estabilidade de suas atividades na cidade de Guarulhos.

O objetivo geral é demonstrar que por meio da implantação do sistema de RFID, no estoque de produtos considerados itens críticos do Home Center haverá redução dos custos operacionais, onde os objetivos específicos referem-se a:

\section{- Minimizar furtos e avarias no estoque \\ - Melhorar os níveis de eficiência das operações de movimentação e estocagem.}

O problema de pesquisa está relacionado ao fato da empresa estudada ter perdas não identificadas de determinados produtos, o que reduz o faturamento da mesma. Dessa forma, a pergunta de norteou o estudo foi: Como melhor controlar o estoque de itens críticos do Home Center através da implantação de um sistema simples de rádio frequência?

Sendo a principal hipótese da referida problemática, o comprometimento da acuracidade dos estoques da empresa, uma vez que o grande número de itens estocados e a contagem manual do estoque físico, favorecem as falhas de contagem e avarias no manuseio dos mesmos, impactando nos custos operacionais desta.

A metodologia utilizada conforme Gil (2002), foi a técnica exploratória, através da análise quantitativa de dados levantados na empresa estudo de caso por meio de entrevistas com o gerente de operações do Home Center e observação dos processos de movimentação, armazenagem, controle de estoque físico e sistêmico da empresa. Também foram realizadas revisão bibliográfica e a adoção de artigos publicados em revistas científicas, journals e teses de mestrado, por terem alto grau de confiabilidade. Trata-se de um estudo de caso, conforme Yin (2015) que investiga um fenômeno contemporâneo em seu contexto no mundo real. 
Após o levantamento dos dados junto ao Home Center, o estudo teve início com a análise dos indicadores da empresa, que demonstraram grandes perdas de estoque, se observou o sistema SAP usado pela empresa, que controla virtualmente o estoque. Para efeitos de estudo de viabilidade de implantação do RFID, foram selecionados itens considerados de críticos, por serem os mais propensos a furtos ou avarias no Home Center. Visando demonstrar o valor de investimento inicial no RFID, foi realizado um orçamento de todo o sistema, junto a uma empresa especializada e, por fim, foi feita a análise dos resultados comparando-os com outra publicação científica.

A estrutura deste artigo está dividida em embasamento teórico, desenvolvimento da temática, resultados e discussão e considerações finais.

\section{EMBASAMENTO TEÓRICO}

Este estudo foi embasado por relevantes conhecimentos procedidos de artigos, teses de mestrado e doutorados, livros e sites sobre tema.

\subsection{VAREJO}

O varejo brasileiro, assim como o mundial, está em constantes mudanças. Tal fator se deve ao nível de exigência dos clientes que vem aumentando e, também, pelo avanço tecnológico da concorrência (PRATES, 2016). Utilizar ferramentas para controlar o estoque em comércios varejistas traz diversos benefícios tais como: compra no momento certo, atendimento ao cliente sem falta de produtos, redução dos estoques, redução das perdas ocasionadas por furtos, entre outros (RIBEIRO et al, 2015).

Segundo Miranda et. al (2016), o comercio varejista é muito vulnerável, quando se trata do tema furto, o fato é que muitas empresas, por falta de controle nem sempre conseguem distinguir o furto de outros tipos de perdas. Dessa forma, é necessário que a gestão de estoques utilize dos recursos disponíveis no mercado da tecnologia para que as ferramentas de controle de estoque, como o RFID, por exemplo, sejam também uma forma de prevenir as perdas.

\subsection{ESTOQUE}

A correta gestão dos custos de estoques faz com que os custos totais ao longo da cadeia favoreçam a formação de um preço de venda menor, beneficiando o consumidor final e aumentando a fidelidade (LIMA et al, 2015). Essa visão do autor mostra claramente o quanto é importante a otimização dos processos, pois se realizado de forma contínua, reduz os gargalos operacionais e os desperdícios de todos os recursos disponíveis.

Segundo Ballou (2006), os custos de estocagem podem chegar até $40 \%$ do seu valor total. Esse dado mostra a importância de uma correta gestão da armazenagem. Obviamente esse valor nunca chegará ao zero, mas é possível que seja reduzido em $20 \%$, ou até menos. A estocagem é uma não é uma das mais fáceis, uma vez que os principais processos são realizados manualmente, estão a mercê dos erros humanos, e, consequentemente, a erros sistêmicos.

Para Souza et al. (2017), se o tempo de reabastecimento for menor que a demanda, ocorrerá um acúmulo desnecessário de materiais. Encontrar o ponto ótimo de reposição faz com que não ocorram faltas e nem sobras no estoque, uma vez, que os materiais são repostos na quantidade e local exatos conforme a necessidade do sistema. Além do mostrado, o excesso de estoques tende a aumentar problemas com furtos e avarias.

Para Alves et al. (2014), configura-se autosserviço varejista, os sistemas de vendas onde o cliente escolhe o produto e realiza o pagamento sem que haja a interferência de funcionários. O autosserviço tende a ter maiores problemas em relação a furtos e avarias. Objetos com pequenas dimensões e/ou de alto valor agregado, mesmo com sistema de monitoramento, estão propensos a furtos, já as avarias, porque o cliente manuseia muitas vezes os produtos para leitura de rótulos, o que pode gerar quebra parcial ou total da mercadoria. Dessa forma, o estoque deste sistema deve ser disposto de uma forma que minimize as ocorrências citadas para que não haja problemas de avarias, que geram custos, e como consequência diminuem o faturamento da empresa. 


\subsection{ARMAZENAGEM}

De acordo com Rodrigues et al. (2011) a gestão do armazém sempre foi um desafio para as empresas, pois a manutenção do estoque de modo que fique acessível e com prazos de atendimento menores, tornou-se um dos fatores de competência para as mesmas.

Segundo Silva et al. (2013), na armazenagem, assim como em outros processos, a utilização de softwares integrados de gestão contribui para a melhoria de resultados. Cada vez mais as distâncias entre empresas de outras cidades, países e até outros continentes vem diminuindo graças às novas formas de gestão logística. A concorrência não está somente no bairro vizinho, às vezes está em qualquer lugar do mundo. Melhorar a gestão de todos os processos, mais do que nunca, passou de uma mera forma de reduzir custos para uma maneira de se manter vivo no ramo em que atua. Softwares integrados auxiliam na otimização do processo para que as empresas ganhem em sua operação desde a compra da matéria prima até a entrega no cliente final.

Ainda se tratando de custos de armazenagem, De Faria e Soares (2014), afirmam que o fluxo de materiais, distância entre processos e a utilização dos equipamentos de movimentação necessitam estar sincronizados para que não haja desperdícios. O layout do armazém influencia diretamente nos resultados, pois se não houver uma lógica na rota seguida pelo material, em médio prazo, será facilmente notado que o tempo praticado não é o ideal, assim, aumentando os custos.

\subsection{TECNOLOGIA DA INFORMAÇÃO E COMUNICAÇÃO / RIFD}

A tecnologia da informação e comunicação aliada a logística otimiza as operações e contribui como fator competitivo. Os sistemas integrados são tão importantes que, hoje em dia, um produto que acabara de passar pelo caixa no ponto de venda é automaticamente solicitado no centro logístico mesmo que esse esteja em uma grande distância e caso não haver no estoque, também existe a possibilidade de solicitar diretamente a reposição de forma imediata, para que o cliente seja atendido.

Pereira et al. (2016) e Bowersox et al. (2013), entendem que a utilização dos sistemas de identificação por rádio frequência e do código de barras contribui para uma melhor gestão. Essas ferramentas ajudam no controle e segurança, otimizando o setor de armazenagem, uma vez que, com sua utilização, se sabe a localização exata de determinado produto, sem interferências de operações manuais.

O trabalho manual necessita de concentração constante por parte do colaborador, pois qualquer erro prejudicará todos os outros processos. Um setor de grande importância como o de recebimento, por exemplo, quando ocorre algum erro na quantidade informada manualmente, a detecção do mesmo levará mais tempo para acontecer, e por muitas vezes devido a fatores como alto grau de dificuldade de localização do item no estoque e de identificação do responsável pela conferência. Já a coleta de informações através do leitor de código de barras e depois a inserção no sistema de rádio frequência, faz com que os erros sejam praticamente extinguidos e mesmo que haja, é possível identificar o local, hora e quem realizou a conferência (ALVES, 2016).

\section{DESENVOLVIMENTO DA TEMÁTICA}

\subsection{O ESTUDO DE CASO}

A empresa estudada é um Home Center situado na cidade de Guarulhos, de origem chilena e que, por diferenças culturais, tem alguns processos de vendas não adotados pelas lojas brasileiras, como por exemplo, oferecer os produtos através do autosserviço. A escolha do case deu-se pela forma como a empresa busca pelo crescimento no mercado brasileiro, assim como pela grande quantidade de itens estocados e pela forma inovadora oferecer os produtos. A opção por implantar um sistema de RIFD, justifica-se por meio dos bens sucedidos casos de implantação do mesmo em grandes empresas, onde a sua aplicação trouxe bons resultados, principalmente em empresas do segmento varejista.

O Home Center possui duas divisões, uma externa que contém produtos como portas, torneiras, azulejos, entre outros e a outra com telhas, pedra, cimento, entre outros. Nesta divisão existe fragilidade quanto à segurança dos produtos, pois utiliza o autosserviço como prática de vendas. A escolha desse método de vendas ocorreu devido à busca por formas de reduzir seu efetivo, propondo de forma 
voluntária, que o cliente se sirva. A compra é toda realizada pelo cliente que entra com seu próprio veículo no pátio, escolhe os produtos que deseja levar, anota o que comprou e por último, efetua o pagamento no caixa. A outra divisão da Home Center fica na parte interna da loja, usa o método convencional de vendas praticado pelas lojas de varejo.

\subsection{COLETA DE DADOS}

Os dados para apresentar os problemas de estoque são os de Março de 2017, uma vez que são os mais recentes e por estarem na média de perdas dos últimos 12 meses. 0 estudo teve início com a definição do que precisaria ser identificado e rastreado pela rádio frequência. Os gráficos abaixo mostram quais setores e categorias de produtos mereciam maior atenção.

O Gráfico 1 apresenta os valores das quebras identificadas e não identificadas do mês de Março de 2017. O maior percentual é relativo às perdas operacionais, como por exemplo: produtos não encontrados no estoque da loja, erros de caixa, entre outros erros.

Gráfico 1: Relatório de perdas mês de Março/2017

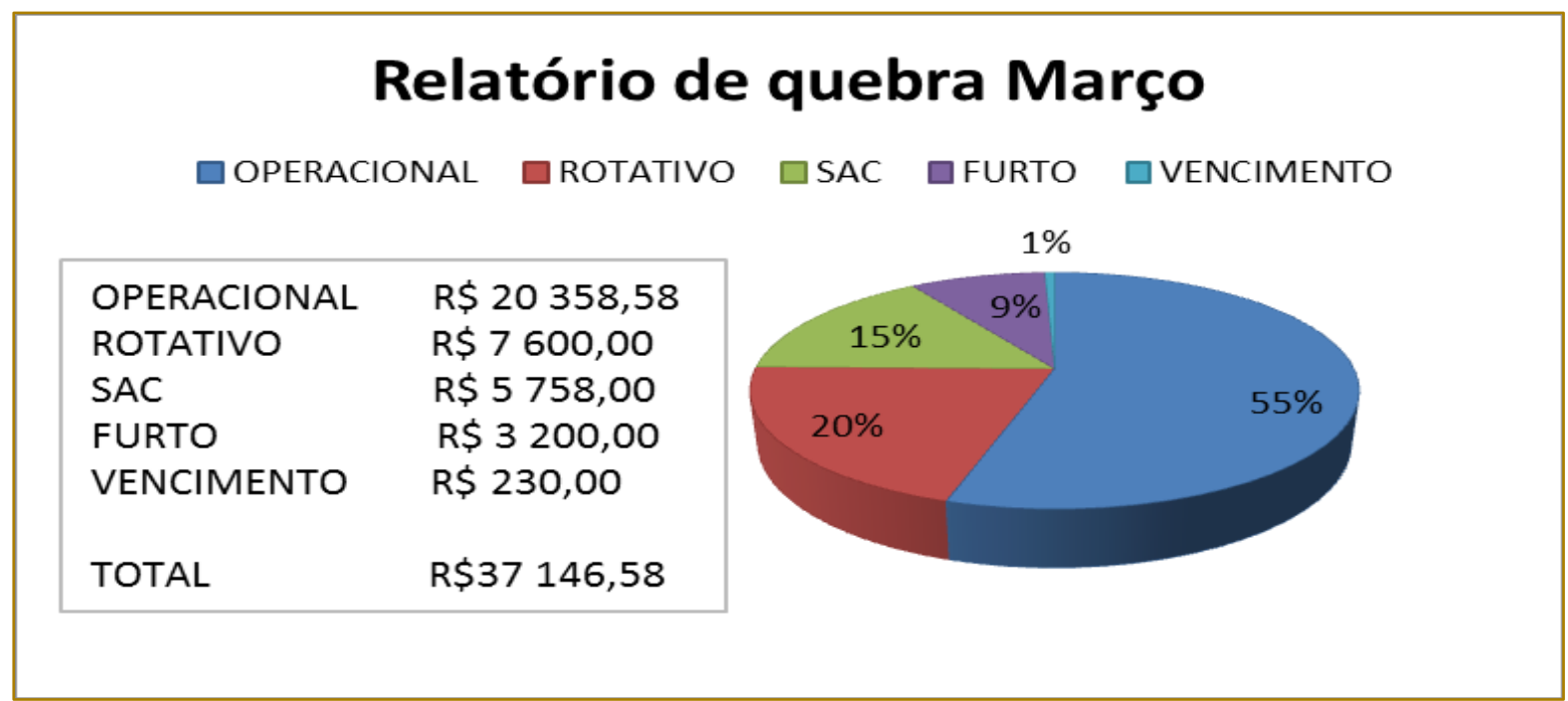

Fonte: Empresa objeto de estudo(2017).

O Gráfico 2 mostra as perdas de estoque divididas por setor, onde os valores referemse apenas aos produtos críticos de cada setor. O setor Jardim apresentou o maior resultado de perdas por causa das plantas e outros equipamentos de alto valor agregado e de difícil monitoramento devido a pequena dimensão. Outro ponto que chama atenção é o fato de alguns produtos como torneiras e similares de alto valor, a baixa no sistema seja feita sem que exista nenhuma movimentação no controle manual por parte do conferente, ou seja, não se localiza o item. Dessa forma não se caracteriza este tipo de ocorrência como furto, por parte da empresa. 


\section{Quebra por setor mês de Março}
口Jardim
$\square$ Cozinha
Hidráulica
Iluminação
$\square$ Decoração
Outros

\begin{tabular}{|ll|}
\hline Jardim & $\mathrm{R} \$ 9477,46$ \\
Outros & $\mathrm{R} \$ 7376,00$ \\
Cozinha & $\mathrm{R} \$ 6919,31$ \\
Hidráulica & $\mathrm{R} \$ 4500,16$ \\
Iluminação & $\mathrm{R} \$ 4301,85$ \\
Decoração & $\mathrm{R} \$ 4273,86$ \\
TOTAL & $\mathrm{R} \$ 37146,58$ \\
\hline
\end{tabular}

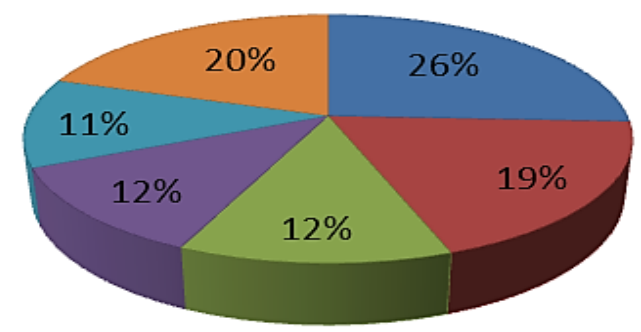

Fonte: Empresa objeto de estudo(2017).

\subsection{PROPOSTA DE IMPLANTAÇÃO DO SISTEMA RFID}

Como mencionado, os primeiros produtos a serem utilizados sistema RFID, serão torneiras de monocomando, furadeiras, equipamentos eletrônicos, ferramentas manuais, entre outros produtos de alto valor e risco.

Para a elaboração do investimento financeiro a ser feito pela empresa objeto de estudo, foi solicitado à uma empresa especializada em implantação do sistema RFID um orçamento. Essa empresa, que será denominada $X$, também fica situada na cidade de Guarulhos/SP. Como fornecedora a mesma optou, a princípio, por implantar um sistema não muito complexo, mas com qualidade e que atendesse às necessidades do Home Center, isso devido ao custo e também para que o procedimento não prejudicasse o atual sistema, SAP. O projeto constitui em fornecer os equipamentos tais como: 20000 etiquetas passivas, 8 antenas, 5 leitores portáteis, 1 decodificadores e 1 software de gestão; implantá-los e treinar a equipe de TI. Esse orçamento foi realizado após análise do giro de estoque (Tabela 1) que justificou a quantidade de etiquetas utilizadas em um período de dois anos, uma vez que a média de giro de estoque, segundo o gerente operacional do Home Center, é de 25 meses. Com isso, o valor total do orçamento ficou em $\mathrm{R} \$ 264300,00$.

Tabela 1: Giro de estoque em dois anos

\begin{tabular}{|l|c|c|c|}
\hline \multicolumn{1}{|c|}{ Setor } & Estoque mensal médio & Demanda prevista (2 anos) & Giro de estoque (2 anos) \\
\hline Cozinha & 200 & 3800 & 19 \\
\hline Hidráulica & 160 & 4100 & 26 \\
\hline Iluminação & 100 & 2500 & 25 \\
\hline Jardim & 15 & 400 & 27 \\
\hline Decoração & 170 & 4100 & 24 \\
\hline Outros & 140 & 3500 & 25 \\
\hline
\end{tabular}

Fonte: Empresa objeto de estudo (2017). 


\section{RESULTADOS E DISCUSSÃO}

Nakashima (2015), em um estudo similar sobre a implantação de um sistema de RFID concluiu que a redução das perdas ficaria em torno de 30\%. Devido a isso, o presente artigo utilizou o valor das perdas do mês de Março/2107 que foi de $\mathrm{R} \$ 37$ 146,58 para fins de cálculo, pois a mesma está na média dentro do período de um ano. Ainda conforme o artigo usado como comparativo, houve a diminuição do quadro de funcionários em menos um conferente, que mensalmente custaria para a empresa $\mathrm{R} \$ 2$ 489,56.

A Tabela 2 refere-se ao valor da redução mensal de perdas e custos operacionais ocasionados pela implantação do RFID na empresa objeto de estudo.

Tabela 2: Redução mensal de custos com a Implantação do RFID (Ano 2017)

\begin{tabular}{|c|c|c|c|c|c|}
\hline CORTE DE FUNCIONÁRIO & \multicolumn{2}{|r|}{$1 X$} & $R \$ 2.489,56$ & & 2489,56 \\
\hline REDUÇÃO PERDAS & $\mathrm{RS}$ & 37146,58 & $\times 0,3$ & $\mathrm{R} \$$ & 11143,97 \\
\hline TOTAL & & & & $\mathrm{R} \$$ & 13633,5 \\
\hline
\end{tabular}

Fonte: Elaborado pelos autores.

De acordo com o estudo efetuado foi possível analisar os valores obtidos de redução das perdas em alguns setores da empresa e o orçamento feito para a implantação do sistema de RFID nos processos. Desta forma, foi efetuado o cálculo do Payback, também chamado de período de retorno de investimento, que é um método de avaliação de investimentos que consiste em calcular o número de períodos (neste caso são meses) necessários para que se recupere um investimento feito. Conforme este estudo de caso, os cálculos do Payback são representados na (Tabela 3) abaixo:

Tabela 3: Dedução do investimento com payback.

\begin{tabular}{|c|c|c|c|c|}
\hline \multirow{2}{*}{$\begin{array}{l}\text { Período } \\
\text { Hoje }\end{array}$} & \multicolumn{2}{|c|}{ Redução das perdas } & \multicolumn{2}{|c|}{ Orçamento do investimento } \\
\hline & $\mathrm{R} \$$ & - & $-\mathbf{R} \$$ & $264.300,00$ \\
\hline 1ํMês & $\mathrm{R} \$$ & $13.633,53$ & $-\mathrm{R} \$$ & $250.666,47$ \\
\hline 2o Mês & $R \$$ & $13.633,53$ & $-\mathrm{R} \$$ & $237.032,94$ \\
\hline 3o Mês & $\mathrm{R} \$$ & $13.633,53$ & $-\mathrm{R} \$$ & $223.399,41$ \\
\hline 4ํo Mês & $R \$$ & $13.633,53$ & $-\mathrm{R} \$$ & $209.765,88$ \\
\hline 5o Mês & $\mathrm{R} \$$ & $13.633,53$ & $-\mathrm{R} \$$ & $196.132,35$ \\
\hline 6을 & $R \$$ & $13.633,53$ & $-R \$$ & $182.498,82$ \\
\hline 7oMês & $R \$$ & $13.633,53$ & $-\mathrm{R} \$$ & $168.865,29$ \\
\hline 8 Mês & $\mathrm{R} \$$ & $13.633,53$ & $-\mathrm{R} \Phi$ & $155.231,76$ \\
\hline 90 Mês & $R \Phi$ & $13.633,53$ & $-R \$$ & $141.598,23$ \\
\hline $10^{\circ}$ Mês & $R \$$ & $13.633,53$ & $-\mathrm{R} \$$ & $127.964,70$ \\
\hline 11을 & $\mathrm{R} \$$ & $13.633,53$ & $-\mathrm{R} \Phi$ & $114.331,17$ \\
\hline $12^{\circ}$ Mês & $R \$$ & $13.633,53$ & $-R \$$ & $100.697,64$ \\
\hline $13^{\circ}$ Mês & $R \$$ & $13.633,53$ & $-\mathrm{R} \Phi$ & $87.064,11$ \\
\hline 14으소s & $R \$$ & $13.633,53$ & $-\mathrm{R} \$$ & $73.430,58$ \\
\hline 15으소s & $R \$$ & $13.633,53$ & $-\mathrm{R} \$$ & $59.797,05$ \\
\hline $16^{\circ}$ Mês & $\mathrm{R} \Phi$ & $13.633,53$ & $-R \Phi$ & $46.163,52$ \\
\hline 17으 Mês & $\mathrm{R} \$$ & $13.633,53$ & $-R \Phi$ & $32.529,99$ \\
\hline $18^{\circ}$ Mês & $R \$$ & $13.633,53$ & $-\mathrm{R} \$$ & $18.896,46$ \\
\hline 19을 & $R \Phi$ & $13.633,53$ & $-R \Phi$ & $5.262,93$ \\
\hline 20 Mês & $R \$$ & $13.633,53$ & $R \$$ & $8.370,60$ \\
\hline 21ํMês & $R \$$ & $13.633,53$ & $\mathrm{R} \$$ & $22.004,13$ \\
\hline 220 Mês & $\mathrm{R} \$$ & $13.633,53$ & $\mathrm{R} \$$ & $35.637,66$ \\
\hline 23ํMês & $R \$$ & $13.633,53$ & $R \$$ & $49.271,19$ \\
\hline 24으ำs & $\mathrm{R} \$$ & $13.633,53$ & $\mathrm{R} \$$ & $62.904,72$ \\
\hline
\end{tabular}

Fonte: Elaborado pelos autores. 
$\mathrm{Na}$ tabela acima o valor do investimento orçado e a redução das perdas conforme o período de meses, iniciando-se no valor inicial do investimento, que é $\mathrm{R} \$ 264.300,00$ e abatendo de acordo com o valor estimado de redução das perdas que é $R \$ 13.633,53$.

Com a análise através do método de Payback calculado, foi previsto que o retorno do investimento se daria entre o $19^{\circ}$ e o $20^{\circ}$ Mês, a partir deste momento o investimento seria pago em relação ao risco do projeto. Neste caso foi utilizada uma postura conservadora e será considerado o arredondamento pior, então o resultado do Payback deste projeto seria 20 meses.

No Cálculo 1 demonstrado a seguir pode-se verificar de uma forma mais precisa o período em que haverá o retorno do investimento, o Payback.

\begin{tabular}{|l|l|l|}
\hline $\mathrm{R} \$ 264.300,00$ & $=$ & 19,39 Meses ou 20 Meses (Arredondamento) \\
\hline $\mathrm{R} \$ 13.633,53$ & & \\
\hline
\end{tabular}

Como foram observadas, as duas formas de se calcular o Payback se validam e demonstram o $20^{\circ}$ mês como o período em que realmente haverá o retorno do investimento.

Neste estudo foi considerado que o sistema de RFID não será substituído no mercado dentro dos próximos 20 meses, portanto, não ficará obsoleto enquanto a empresa ainda estiver pagando o seu investimento ou até mesmo num período médio de prazo de três anos, o investimento será aceitável para a empresa diante deste cenário.

\section{CONSIDERAÇÕES FINAIS}

O estudo buscou uma forma de inserir um novo sistema de controle de estoque que junto com o sistema atual SAP, trouxesse uma melhor gestão do estoque, com um custo de investimento financeira aceitável para empresa objeto de estudo. O primeiro desafio foi encontrar uma empresa de confiança que fornecesse esse tipo de serviço. O lado positivo de contratar um especialista é a garantia nos equipamentos e treinamento dos funcionários

O objetivo principal deste artigo que foi a redução dos custos através da implantação do sistema de RFID, de um modo geral foi alcançado, porque a partir do $20^{\circ}$ mês a empresa começará a obter lucros e os custos de implantação já estariam deduzidos. Ao analisar os resultados ficou comprovado que - sistema RFID para controlar estoques, mesmo com alto custo de implantação, traz ótimos resultados a médio prazo. O novo sistema reduzirá o quadro de funcionários em menos 1 conferente e as perdas em média $30 \%$.

A contribuição deste artigo foi trazer para empresa objeto de estudo um melhor controle dos itens de estoque fisicamente, principalmente os considerados críticos, para o meio acadêmico ficou por conta da análise realizada sobre $\mathrm{o}$ investimento $\mathrm{X}$ retorno ao longo do tempo.

Foi possível concluir que de fato o RFID traz grandes benefícios em médio prazo mesmo que seja utilizado em apenas parte dos ativos de uma organização. Isso inclusive pode representar uma limitação neste estudo, já que poderia ser implantado em todo o estoque, mas que poderá ser explorado em outra oportunidade futura. Uma segunda oportunidade de continuação de estudos ficou por conta da ferramenta Payback, pois embora seja considerado um cálculo simples, possui a deficiência de não considerar o valor do dinheiro no tempo, para isso deve ser utilizado o método do Payback descontado.

\section{REFERÊNCIAS}

[1]. ALVES, Paulo Roberto. Estudo exploratório da adoção da tecnologia RFID no controle de estoque de almoxarifado com base na opinião da área operacional de usinas sucroalcooleiras. Dissertação de Mestrado em Engenharia de Produção pela Faculdade de Engenharia de Bauru da Universidade Estadual Paulista "Júlio de Mesquita Filho". 2016. Disponível em: http://hdl.handle.net/11449/143806. Acesso em 04 abr. 2017. 
[2]. ALVES, Roberta; DOS SANTOS, José Airton Azevedo; SCHMIDT, Carla Adriana Pizarro. Aplicação dos princípios da teoria das restrições e de técnicas de simulação na gestão da dinâmica operacional de um pequeno restaurante: um estudo de caso. Revista ESPACIOSI Vol. 35 (№ 7) Año 2014, 2014. Disponível em: http://www.revistaespacios.com/a14v35n07/143507 21.html. Acesso em: 01 abr.2017.

[3]. BALLOU, Ronald H. Gerenciamento da cadeia de suprimentos. São Paulo: Ed. 2006.

[4]. BOWERSOX, Donald J. et al. Gestão logística da cadeia de suprimentos. AMGH Editora, 2013.

[5]. CRACO, Tania et al. Logística reversa usada como estratégia de fidelização. REN-Revista Escola de Negócios, v. 2, n. 1 jan/jul, p. 215-224, 2014. Disponível em: http://chamados.fadergs.edu.br/index.php/administ racao/article/view/64. Acesso em: 11 mar. 2017.

[6]. DE FARIA, Juliana Carvalho; SOARES, Leandro. GESTÃO DE MATERIAL EM UM ARMAZÉM E SUA IMPORTÂNCIA PARA A EMPRESA. Cadernos UNISUAM de Pesquisa e Extensão, v. 4, n. 1, p. 32-40, 2014. Disponível em:

[7]. http://apl.unisuam.edu.br/revistas/index.ph $\mathrm{p} /$ cadernosunisuam/article/view/604. Acesso em: 11 abr. 2017.

[8]. DE LIMA NUNES, Fabiano; MENEZES, Felipe Morais. SISTEMA HYUNDAI DE PRODUÇÃO E SISTEMA TOYOTA DE PRODUÇÃO: SUAS INTERAÇÕES E DIFERENÇAS. Revista Acadêmica São Marcos, v. 4, n. 2, p. 101-120, 2015. Disponível em:

http://www.saomarcos.br/ojs/index.php/rasm/article /view/79. Acesso em: 07 mar. 2017.

[9]. GIL, Antonio Carlos. Como elaborar projetos de pesquisa. São Paulo, v. 5, p. 61, 2002.

[10]. GUIDI, Rafael Rodrigues; BRAGA, Vanessa Caroline. Avaliação da qualidade de um sistema de gestão do armazém. 2015. Disponível em:

http://bd.centro.iff.edu.br/handle/123456789/627.

Acesso em: 27 mar.2017.

[11]. MIRANDA, R. F. Q., DUARTE, D. L., RIBEIRO, L. C. M., \& BZERRA, M. R. (2016). REDUÇÃO DA INACURÁCIA DAS INFORMAÇÕES DE ESTOQUE DE SOBRESSALENTES EM NAVIOS DE GUERRA COM A UTILIZAÇÃO DA TECNOLOGIA RFID. Blucher Marine Engineering Proceedings, 2(1), 113-124. Disponível em : http://pdf.blucher.com.br/marineengineeringprocee dings/spolm2015/139995.pdf. Acesso em: 04 jun. 2017
[12]. PEREIRA, Júlio César Brasil et al. SISTEMA AUTOMATIZADO DE VAGA VEICULAR PARA DEFICIENTES FÍSICOS E IDOSOS UTILIZANDO A TECNOLOGIA RFID. Nanbiquara, v. 5 , n. 2, 2016. Disponível em: http://periodicos.fametro.edu.br/index.php/nanbiqu ara/article/view/194. Acesso em: 26 mar. 2017.

[13]. RODRIGUES,F.E., et al. Logística Integrada Aplicada a um Centro de Distribuição: Comparativo do Desempenho do Processo de Armazenagem Após a Implementação de um Sistema de Gerenciamento de Armazém (wms). VIII SEGET, 2011. Disponível em : http://www.aedb.br/seget/arquivos/artigos 11/13514 97.pdf.Acesso em : 04 jun. 2017.

[14]. PRATES, M. L. (2016). Uso do Big Data na construção de valor no varejo: estudo de caso do Wal-Mart. Dissertação de Mestrado em Ciência da Computação PUC - São Paulo, 2016. Disponível em: https://tede.pucsp.br/handle/handle/19657. Acesso em: 04 jun. 2017.

[15]. PINTAUDI, S. M. (2017). MUDANÇAS NAS FORMAS DE COMÉRCIO VAREJISTA E A IMPLANTAÇÃO DOS SUPERMERCADOS NA GRANDE SÃO PAULO-SP-BRASIL. Boletim Paulista de Geografia, (66), 23-38. Disponível em: http://www.agb.org.br/publicacoes/index.php/boleti mpaulista/article/view/954. Acesso em: 04 jun. 2017

[16]. RIBEIRO, P. C. C., dos Santos Machado, M. D., Meyer, N. R. M., \& Romano, R. R. (2015). AVALIAÇÃO DA APLICAÇÃO DA RADIO FREQUENCY IDENTIFICATION NO VAREJO DE VESTUÁRIO NOS ELOS FORNECEDOR E CLIENTE. Iberoamerican Journal of Project Management, 6(2), 77-99. Disponível em: http://www3.fi.mdp.edu.ar/riipro/journal/index.php/l JOPM/article/view/243. Acesso em: 04 jun. 2017.

[17]. SILVA, Vanina Macowski Durski; PRADO, Jacqueline Ribeiro; BARROS, Thayse Dobis. Logística Colaborativa: um Estudo de Caso no Setor de Armazenagem e Logística. Encontro Nacional de Engenharia de Produção, v. 1, p. 1, 2013. Disponível em: http://www.aedb.br/seget/arquivos/artigos13/20218 131.pdf. Acesso em:26 mar. 2017

[18]. SOUZA, Caroline Santa Rosa; DE OLIVEIRA, Meire Ramalho. PROPOSTA DE GESTÃO DE ESTOQUE PARA UMA EMPRESA VAREJISTA EM ILHÉUS-BA. Revista Gestão Industrial, v. 12, n. 4, 2017. Disponível em: https://periodicos.utfpr.edu.br/revistagi/article/view/ 4701. Acesso em: 26 mar. 2017.

[19]. YIN, Robert K. Estudo de Caso: Planejamento e Métodos. Bookman editora, 2015. 


\section{Bapítulo 6}

\section{ESTUDO DE CASO: SIMULAÇÃO APLICADA NO PROCESSO DE RECEBIMENTO E EXPEDIÇÃO DE UM HIPERMERCADO}

\section{Peterson Rony Vicente de Matos}

\section{Cristovão Rocha Sousa}

\section{Roberto Ramos de Morais}

Resumo: O presente artigo se propõe, mediante os conhecimentos teóricos exibidos na revisão bibliográfica e a utilização do software de simulação, denominado Arena $\AA^{2}$, modelar e analisar o processo de organização, de separação e expedição, recebimento e armazenamento nas operações logística de uma rede de hipermercados, que se dá entre três unidades de vendas e seu Centro de distribuição, definindo os pontos críticos predominantes presentes nestes processos e apresentando sugestões que viabilize sua melhoria. No quesito obtenção dos dados objetivando a realização do presente estudo de caso, foram utilizados dados adquiridos mediante processos de entrevistas junto ao responsável do departamento de logística. Por meio destes dados foi possível averiguar que o Centro de Distribuição possui problemas no processo de separação de sortimentos e montagens dos paletes para envio às Unidades de Vendas, devido ao alto índice de ociosidade de seus recursos, o que reflete em forma de rupturas de gondolas, nas respectivas Unidades de vendas, ocasionando danos financeiros oriundos das perdas de vendas.

Palavras-chave: Centro de Distribuição. Unitização. Simulação. Arena®. 


\section{INTRODUÇÃO}

O Arena ${ }^{\circledR}$ é composto por um conjunto de blocos (ou módulos) utilizados para se descrever uma aplicação real e que funcionam como comandos de uma linguagem de programação. Os elementos básicos da modelagem em Arena® são as entidades que representam as pessoas, objetos, transações, etc. que se movem ao longo do sistema; as estações de trabalho que demonstram onde será realizado algum serviço ou transformação, e por fim, o fluxo que representa os caminhos que a entidade irá percorrer ao longo de estações. (PRADO, 1999)

Tal como a maioria dos softwares de simulação, o Arena ${ }^{\circledR}$ visualiza o sistema a ser modelado como constituído de um conjunto de estações de trabalho que prestam serviços aos clientes. O Arena $®$ tem sido utilizado para simular os mais diversos ambientes, desde linhas de produção, minas, tráfego nas ruas de uma cidade e diversos ambientes logísticos. Inicialmente, como as linguagens de programação Fortran, Basic, Pascal, etc. os sistemas de simulação foram desenvolvidos sobre linguagens de programação de propósito geral. No entanto, isso exigia um grande esforço para construção de modelos, além de programadores de computadores. Perante essa dificuldade é que começaram a surgir linguagens de programação, dedicadas à simulação, que solucionaram esse problema.

Foram desenvolvidas linguagens formadas por conjuntos de macro comandos das linguagens de propósito gerais como no caso de Gpss, Siman, Slam, Simscript, etc. Alguns dos simuladores da geração seguinte foram desenvolvidos sobre a plataforma dessas linguagens. Como exemplo tem-se o software Arena $₫$, implementado na linguagem Siman.

O Arena ${ }^{\circledR}$ foi lançado pela empresa americana Systems Modeling em 1982. O sistema possui um conjunto de blocos que funcionam como comandos de uma linguagem de programação (PRADO, 2010).

A execução do Arena ${ }^{\circledR}$ se baseia na lógica da programação fornecida pelo modelo (SANTOS e SANTOS, 2016). Segundo Prado (2006) o software Arena ${ }^{\circledR}$ é uma ferramenta para a simulação de eventos, análise de cenários e simular processos, como ele tem uma análise dinâmica e uma interação com elementos do sistema é possível verificar gargalos, melhorar condições de trabalho, controlar filas e funções de seus recursos é observar qual é o comportamento do sistema.

O objetivo deste trabalho visa apresentar possíveis propostas aos problemas encontrados nas operações logísticas de uma grande rede varejistas que atua no mercado nacional a mais de quarenta anos.

\section{EMBASAMENTO TEÓRICO}

Uma das aplicações mais comum da simulação está relacionada à diminuição de tempo que uma entidade consome nos sistemas. As entidades são itens processados no sistema podendo representar peças, pessoas ou qualquer outro recurso.

De acordo com Costa (2006) a simulação é um exemplo computacional que consegue demonstrar ocorrências reais, para que sejam analisados, avaliados e entendidos, dando a oportunidade das empresas uma opção para implantar novas estratégias que possam melhorar a operação.

Szymankiewci (1988) conceitua simulação da seguinte maneira: "simulação é uma das mais poderosas técnicas disponíveis para resolução de problemas, consiste na construção de um modelo matemático, correspondente ao sistema real, que pode ser experimentado e analisado, quando submetido a diversos cenários de ação".

Segundo Silva e Junior (2013) a modelagem dos processos é a análise e interpretação dos processos existentes, do mesmo modo que necessita o registro detalhado de todas as etapas necessárias para 0 seu funcionamento.

Conforme Oliveira (2008) existe uma série de vantagens em se utilizar a simulação computacional, salientando que a simulação permite verificar o funcionamento antes de sua construção, apoiando a análise financeira de um projeto, permitindo realizar testes nos processos sem que haja intervenção no processo, possibilitando identificar possíveis gargalos.

A utilização da simulação tem sido cada vez mais utilizada por ser uma técnica que permite as analistas verificarem ou encaminharem soluções desejadas para os problemas do dia a dia. Segundo Freitas Filho (2008) o estudo de simulação economiza tempo e recursos financeiros no desenvolvimento do projeto, oferecendo ganho na produtividade e qualidade. Os 
custos das análises se tornam insignificantes se comparado aos seus benefícios.

Este programa apresenta um ambiente gráfico integrado de simulação, que contém todos os recursos para modelagem, animação, análise estatística e análise de resultados e utiliza a abordagem por processos para execução da simulação. Essa técnica de simulação pode ser considerada uma situação onde elementos estáticos, formando um ambiente bem definido com suas regras e propriedades, interagem com elementos dinâmicos, que fluem dentro desse ambiente.

Ainda de acordo com os autores, o Arena $\AA$ trabalha através de fluxogramas o que permite maior interação e possui uma linguagem de interpretação fácil, o que permite que não haja a necessidade de se escrever linhas de códigos como o que ocorre em outros softwares.

\section{MATERIAL E MÉTODOS}

O processo na UL constitui de separar e expedir as mercadorias para cada UV mediante os pedidos enviados via sistema, quando os pedidos estão prontos, o transportador é requisitado a realizar a movimentação até a UV.

Uma vez esse caminhão nas docas da UV, o processo que segue é constituído de um fiscal de prevenção, que realiza todo o processo de verificação das documentações do caminhão e do motorista, além dos romaneios, uma vez esse processo concluído, o motorista é direcionado a uma das quatro docas existentes em cada uma das UVs.

Agora o processo que se segue é o descarregamento que deve levar em consideração alguns pontos importantes: a área de transito deve estar livre de paletes oriundos do caminhão anterior, a equipe azul deve ter realizado a "explosão" separação dos produtos e posteriormente unitiza-los por setor e categorias de produtos, para que a equipe vermelha possa armazena-los no endereço correto, permitindo a movimentação dos paletes recém-chegados.

\subsection{ESTUDO DE CASO}

Foram consideradas as operações logísticas entre uma UL (unidade logística) e três UVs (unidades de vendas) apresenta aqui como Loja um, Loja dois e Loja três que estão distantes a sendo suas distancias respectivamente $120 \mathrm{~km}, 100 \mathrm{~km}$ e $130 \mathrm{~km}$. Para efeito de cálculo de tempo consideramos uma velocidade de $80 \mathrm{~km} / \mathrm{h}$ para cada transportador. As operações logísticas na UL para envio de sortimentos às UVs ocorrem das $6 \mathrm{~h}$ às $23 \mathrm{~h}$ por dia e seis dias por semana, esta atua com 0 Transportador $X$ que efetua as entregas nas UVs. As operações logísticas nas UVs são realizadas de segunda a sábado no período das $6 \mathrm{~h}$ às $14 \mathrm{~h}$, com uma hora de refeição.

Considerando que tais pontos estejam concluídos a fiscalização é chamada para realizar o processo de abertura do baú, liberando a equipe vermelha para descarregamento dos paletes. Concluído este processo a equipe vermelha armazena esses paletes na área de transito para que na manhã seguinte a equipe azul possa realizar o processo de "explosão" dos paletes e o ciclo se renova.

\section{RESULTADOS E DISCUSSÃO}

Após a coleta dos dados, foi desenvolvido o modelo no software Arena $\AA$ para simular o cenário atual dos processos. 
Figura 1 - Relatório final do cenário atual.

\section{Indicadores Chaves de Performance}

\begin{tabular}{|ccc|}
\hline Número de Iterações & Unidade de Tempo & Número médio de Saídas do Sistema \\
\hline 5 & Minutos & 126 \\
\hline
\end{tabular}

Fonte: Os próprios autores (2018).

Figura 2 - Relatório final do cenário proposto.

\section{Indicadores Chaves de Performance}

\begin{tabular}{|ccc|}
\hline Número de Iterações & Unidade de Tempo & Número médio de Saídas do Sistema \\
\hline 150 & Minutos & 666 \\
\hline
\end{tabular}

Cenário atual: foram realizadas 5 iterações, num primeiro momento durante o período de trabalho de 8 horas obtivemos os seguintes resultados da presente situação no que tange aos processos de movimentação e armazenagem.

Ainda considerando esta primeira simulação, notamos uma fila com tempo médio de espera de 77,07 minutos no processo de armazenagem, caracterizando assim o nosso maior gargalo. Visando uma redução de 3\% ou superior deste valor, os cálculos para definir os números de iterações apontam que será necessário realizar uma simulação com um total de 786 iterações.

Contudo devido a restrições na capacidade do software gerar os relatórios, considerando o total de iterações citadas acima, foram consideradas 150 iterações, valor este encontrado a partir da redução de 50 iterações por tentativa, considerando as 786 iterações iniciais.

A porcentagem de utilização de cada recurso no processo de movimentação e armazenagem nota-se que há muita ociosidade nos recursos: Equipe da UL com $6,07 \%$ de utilização, já as equipes azuis na ordem dos $3,96 \%$ de utilização, por sua vez as equipes vermelhas estão mais ocupadas com uma média de utilização de 33,05\%, por sua vez os fiscais de prevenção estão sendo empregados em apenas $3,43 \%$ da sua capacidade total de trabalho. Tais números reforçam a tese de que há oportunidades de melhorias na utilização dos recursos.

Conforme primeiro cenário, considerando-se as três UV, há filas nos processos de armazenagem com foco na Loja três que está com um tempo médio de 48,73 minutos e um tamanho máximo de 19 entidades, por vez a loja dois está realizando a média de tempo em 34,22 minutos com um tamanho máximo de 15 entidades, contra a média de 31,32 minutos praticado pela loja 1 que possui um tamanho de fila de 11 entidades. 
Figura 3 - Simulação do cenário da estrutura logística da rede varejista Ltda.

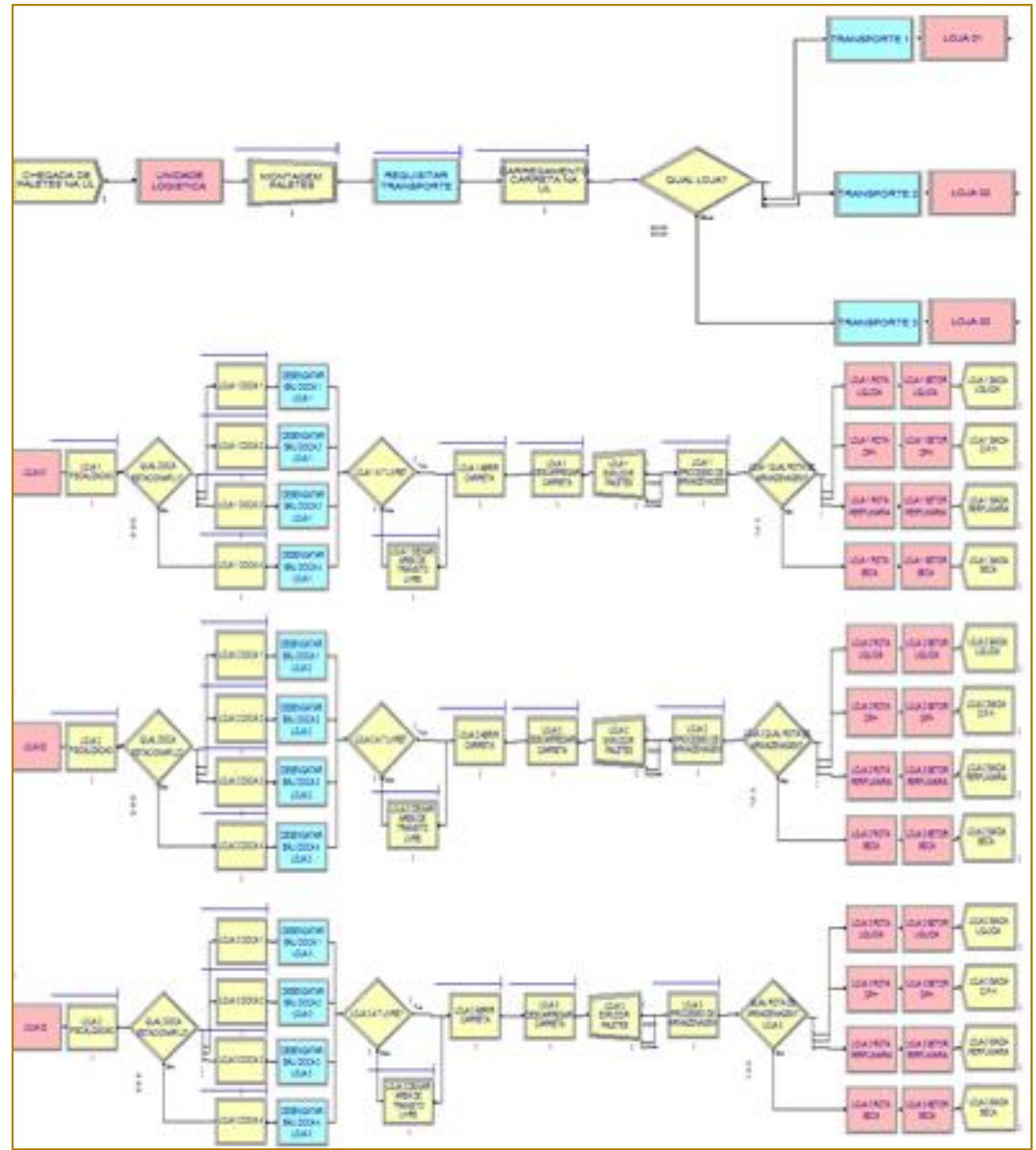

Fonte: Os próprios autores (2018).

Cenário proposto: Seguindo está linha, podese notar que há filas no processo de descarregamento e o foco novamente se direciona a loja três que realiza o processo com uma média de 23,31 minutos e tamanho máximo de fila na ordem das quatro entidades, onde o tempo médio praticado pela loja dois é de 14,26 minutos com um tamanho máximo de fila de três entidades, na contramão está a loja um que apresenta a menor média de tempo com 11,49 minutos, apresentando uma fila de duas entidades como valor máximo.

O processo de fiscalização de lacres para abertura dos baús acarreta pequenas filas que somadas geram uma média de 1,62 minutos e 1 entidade em espera. Os demais processos referentes à fiscalização não ocasionam filas.

Porém o processo de limpeza da área de trânsito apresenta uma fila de 71,24 minutos com 1 entidade em espera na loja dois, a loja três vem com o segundo maior tempo de espera com 28,42 minutos e apresenta o mesmo valor que a loja dois em entidades que aguardam atendimento, por outro lado a loja um apresenta o menor tempo de fila com apenas 2,69 minutos e 1 entidade em espera.

O processo de abertura das carretas apresenta uma fila de 8,22 minutos com 1 entidade em espera na loja três, a loja dois apresenta o segundo pior tempo de espera com 4,21 minutos e esta empatada com a loja dois em entidades que aguardam para ser 
atendida, por outro lado a loja um apresenta o menor tempo de fila com apenas 2,80 minutos e 1 entidade em espera.

Já na UL não há filas no processo de carregamento, porém há uma inversão quando olhamos o processo de montagem dos paletes que nesse primeiro momento está com média de 37,79 minutos com tempo máximo girando em torno de 118 minutos, praticando um tamanho médio de fila na ordem das 14,43 entidades e com máximo de 30 entidades.

Conforme a figura 2, as quantidades de paletes que saíram do processo aumentaram. O que antes era de 126 unidades passou para 666.

Após considerarmos diversas simulações de propostas e cenários, notou-se que o melhor seria intervir no modo como os paletes eram unitizados na UL, a presente proposta defende uma diminuição no tamanho de lote dos paletes/produtos de 93,33\%, ou seja, de 30 para $2 \mathrm{com}$ isso há uma diminuição na ociosidade da equipe UL que estavam atuando com $6,07 \%$ de sua capacidade total está alteração acarretou um acréscimo de $81,52 \%$ sobre a capacidade de trabalho deste recurso que agora atua em 32,84\%, dado este que reflete diretamente nas UVs, uma vez que proporciona um aumento de $81,08 \%$ nos envios de sortimentos as UV, contribuindo para que não haja rupturas devido à falta de sortimentos

A porcentagem de utilização de cada recurso no processo de movimentação e armazenagem nota-se que houve uma acentuada melhoria nos desempenhos das equipes vermelhas onde a equipe da loja um praticava $33,05 \%$ e atualmente $70,24 \%$ uma melhora de $52,95 \%$, por sua vez a equipe vermelha da loja dois estava com $60,11 \%$ de ociosidade, com a presente proposta esse percentual é de $28,72 \%$, ou seja, houve uma redução de 52,22\% na ociosidade desta. Contudo a equipe vermelha loja três apresentava 50,38\% de utilização do recurso, com esta proposta melhorou seu desempenho em $36,89 \%$, passando a praticar $79,83 \%$ da sua capacidade de recurso, sendo esta a melhor equipe em desempenho nos dois cenários analisados.

Tabela 1 - Tempos coletados e expressões

\begin{tabular}{|c|c|}
\hline Procedimento & Expressão \\
\hline CARREGAMENTO CARRETA NA UL & $\operatorname{NORM}(5.08,1.81)$ \\
\hline CHEGADA DE PALETES NA UL & $\operatorname{GAMM}(1.89,1.39)$ \\
\hline LOJA 1 ABRIR CARRETA & UNIF(3.5, 6.5) \\
\hline LOJA 1 DEIXAR AREA DE TRANSITO LIVRE & $52+33^{*} \operatorname{BETA}(0.904,0.864)$ \\
\hline LOJA 1 DESCARREGAR CARRETA & $\operatorname{UNIF}(75,120)$ \\
\hline LOJA 1 DOCA 1 & $3.47^{*} \operatorname{BETA}(1.81,2.11)$ \\
\hline LOJA 1 DOCA 2 & $0.02+3.48$ * $\operatorname{BETA}(1.76,2.43)$ \\
\hline LOJA 1 DOCA 3 & $0.08+5.6$ * $\operatorname{BETA}(1.63,1.86)$ \\
\hline LOJA 1 DOCA 4 & $0.01+5.99 * \operatorname{BETA}(1.72,2)$ \\
\hline LOJA 1 FISCALIZACAO & $11^{*} \operatorname{BETA}(1.19,1.33)$ \\
\hline LOJA 1 PROCESSO DE ARMAZENAGEM & $0.71+2.58$ * $\operatorname{BETA}(1.74,1.72)$ \\
\hline LOJA 1 ROTA DPH & $3.49 * \operatorname{BETA}(1.7,2.11)$ \\
\hline LOJA 1 ROTA LIQUIDA & 3.4 * $\mathrm{BETA}(1.76,2.34)$ \\
\hline LOJA 1 ROTA PERFUMARIA & $0.06+\operatorname{LOGN}(0.964,0.63)$ \\
\hline LOJA 1 ROTA SECA & $\operatorname{LOGN}(1.89,1.21)$ \\
\hline LOJA 2 ABRIR CARRETA & UNIF $(1.5,6.5)$ \\
\hline LOJA 2 DEIXAR AREA DE TRANSITO LIVRE & $67+46$ * $\operatorname{BET} A(0.955,1.01)$ \\
\hline LOJA 2 DESCARREGAR CARRETA & $71+53$ * $\operatorname{BETA}(1.13,1.05)$ \\
\hline
\end{tabular}


Tabela 1 - Tempos coletados e expressões

(continuação...)

\begin{tabular}{|c|c|}
\hline Procedimento & Expressão \\
\hline LOJA 2 DOCA 1 & $3.42{ }^{*} \operatorname{BETA}(1.56,2.17)$ \\
\hline LOJA 2 DOCA 2 & $4.67^{*} \operatorname{BETA}(1.69,2.15)$ \\
\hline LOJA 2 DOCA 3 & 5.87 * $\operatorname{BETA}(1.66,2)$ \\
\hline LOJA 2 DOCA 4 & 6 * $\operatorname{BETA}(1.83,2.02)$ \\
\hline LOJA 2 FISCALIZACAO & $12 * \operatorname{BETA}(1.43,1.51)$ \\
\hline LOJA 2 PROCESSO DE ARMAZENAGEM & 3.4 * $\operatorname{BETA}(3.52,2.41)$ \\
\hline LOJA 2 ROTA DPH & 3.49 * $\operatorname{BETA}(2.15,2.6)$ \\
\hline LOJA 2 ROTA LIQUIDA & $0.01+\mathrm{WEIB}(1.81,2.12)$ \\
\hline LOJA 2 ROTA PERFUMARIA & $0.04+\operatorname{GAMM}(0.324,3.01)$ \\
\hline LOJA 2 ROTA SECA & $0.01+3.99 * \operatorname{BETA}(1.71,1.76)$ \\
\hline LOJA 3 ABRIR CARRETA & UNIF(4.5, 9.5) \\
\hline LOJA 3 DEIXAR AREA DE TRANSITO LIVRE & UNIF(60, 84) \\
\hline LOJA 3 DESCARREGAR CARRETA & $91+42 * \operatorname{BETA}(0.955,0.882)$ \\
\hline LOJA 3 DOCA 1 & $3.44^{*} \operatorname{BETA}(1.28,1.82)$ \\
\hline LOJA 3 DOCA 2 & $0.02+3.51$ * $\operatorname{BETA}(1.78,2.26)$ \\
\hline LOJA 3 DOCA 3 & $0.04+5.6^{*} \operatorname{BETA}(1.68,2.17)$ \\
\hline LOJA 3 DOCA 4 & $0.11+4.89 * \operatorname{BETA}(1.65,1.23)$ \\
\hline LOJA 3 FISCALIZACAO & 11 * $\operatorname{BETA}(1.38,1.67)$ \\
\hline LOJA 3 PROCESSO DE ARMAZENAGEM & $0.71+2.59$ * $\operatorname{BETA}(1.89,1.69)$ \\
\hline LOJA 3 ROTA DPH & $0.06+\operatorname{ERLA}(0.477,3)$ \\
\hline LOJA 3 ROTA LIQUIDA & $3.48{ }^{*} \operatorname{BETA}(1.27,1.79)$ \\
\hline LOJA 3 ROTA PERFUMARIA & $5.72{ }^{*} \operatorname{BETA}(1.61,1.82)$ \\
\hline LOJA 3 ROTA SECA & 6 * $\operatorname{BETA}(1.87,2.2)$ \\
\hline
\end{tabular}

Fonte: Os próprios autores (2018).

Este mesmo relatório traz os seguintes dados sobre as equipes azuis onde podemos inquirir que a equipe azul da loja um no primeiro cenário praticava um percentual baixíssimo de ocupação que girava em torno de 3,96\% com a dada proposta esse percentual teve um aumento de $81,09 \%$, praticando $20,94 \%$ da capacidade, considerando os números apresentados pela equipe azul da loja dois que num primeiro instante apresentava uma taxa de utilização que beirava a casa dos $10 \%$ com 9,52\%, agora está praticando $37,52 \%$ uma aumento de $74,63 \%$ de produtividade. A equipe azul da loja 3 anteriormente estava trabalhando com apenas $5,24 \%$ de sua capacidade de trabalho, no presente momento este percentual é de $36,38 \%$ com uma progressão de $85,60 \%$ sobre o praticado anteriormente.

A fiscalização também foi beneficiada com a proposta simulada, estas equipes atuavam em média com $4,10 \%$ de sua capacidade de execução, com a já descrita proposta este cenário obteve uma melhora de $81,40 \%$, o que contribuiu para o aumento da média em $17,94 \%$ que atualmente gira em torno de 22,04\%, nesse cenário a equipe fiscalização da loja 1 praticava $3,43 \%$ e contribuiu com $83,77 \%$ de evolução ficando $21,13 \%$, com um aumento real de $17,70 \%$ sobre o período anterior, por sua vez a equipe fiscalização loja 
dois estava atuando com 4,06\% de sua capacidade de trabalho atualmente apresenta $20,37 \%$, figurando uma melhora de $80,07 \%$ e pôr fim a equipe fiscalização da loja três que anteriormente praticava $4,80 \%$ e no presente cenário está apresentando uma evolução de $80,50 \%$ atuando com $24,62 \%$. Onde a equipe da loja 1 figura com o melhor desempenho no evolutivo da média com $83,77 \%$ e a equipe da loja três com $24,62 \%$ de sua capacidade de trabalho.

O cenário proposto traz benefícios às operações considerando-se as três UV, há filas nos processos de armazenagem com foco na Loja três que está com um tempo médio de 52,48 minutos, esse valor representa um aumento de 3,76 minutos na média ou $7,16 \%$, o tamanho máximo da fila cresceu saindo de 19 para 42 entidades um aumento de $54,76 \%$, contudo houve um ótimo crescimento no número máximo de saída que anteriormente era de apenas 73 entidades, neste cenário esta saída é 256 entidades, ou seja, um aumento de 358,68\%.

Por sua vez a Loja dois com esta proposta está com um tempo médio de 30,28 minutos, esse valor representa uma redução de 3,94 minutos na média ou 11,51\%, por outro lado o tamanho máximo da fila subiu de 15 para 51 entidades um aumento de $340 \%$, contudo houve um ótimo crescimento no número máximo de saída onde no primeiro cenário ocorria à saída de apenas 68 entidades, com a presente proposta esta saída é 296 entidades, ou seja, um aumento de 435,30\%.

Já a loja um está com um tempo médio de 27,39 minutos, esse valor representa uma redução de 3,92 minutos na média ou $12,55 \%$, como ocorrido nas demais lojas da rede houve um aumentando do tamanho máximo da fila, que nessa loja representa $73,42 \%$, ou seja, havia 11 entidades e no presente momento 43 entidades, porém como também é percebido nas demais unidades houve um gigantesco crescimento no número máximo de saída onde se praticava uma saída de apenas 68 entidades, e atualmente esta saída é 287 entidades, ou seja, um aumento de 422,06\%.

Este cenário proposto também afetou a realidade dos processos de descarregamentos num primeiro instante notava-se que a loja três que realizava o processo com uma média de 23,31 minutos e tamanho máximo de fila na ordem das quatro entidades em espera, com número máximo de saída em 20 entidades atendidas, atualmente está praticando um tempo médio de processo de 39,87 minutos com um tamanho máximo de fila na ordem das nove entidades que aguardam o atendimento tendo 66 entidades atendidas como saída máxima, contra 20 entidades atendidas no primeiro cenário, considerando este último quesito, houve um aumento de $330 \%$, na quantidade de entidades atendidas, e em paralelo houve um aumento de $225 \%$ das entidades em espera, partindo de quatro entidades no primeiro momento para nove neste cenário.

A loja dois por sua vez também teve seu processo de descarregamento afetado frente a este novo cenário, para melhor compreensão vale salientar que está num primeiro instante realizava tal processo com tempo médio de 14,26 minutos com um tamanho máximo de fila que girava em torno de três entidades que aguardavam atendimentos, sendo que o número máximo de entidades atendidas era de 18 entidades. Atualmente está loja está praticando um tempo médio de processo de 22,06 minutos com um tamanho máximo de fila na ordem das 12 entidades que esperam por atendimento tendo 74 entidades atendidas como saída máxima, contra 18 entidades atendidas no primeiro cenário, fazendo um comparativo com este último, houve um aumento de $411,12 \%$, na quantidade de entidades atendidas, e simultaneamente ocorreu um aumento de $300 \%$ das entidades em espera.

A loja um teve seu processo de descarregamento afetado mediante a aplicação desta proposta, vale lembrar que tal loja apresentava um tempo médio para esse processo na ordem dos 11,49 minutos, tendo como tamanho máximo de fila duas entidades que aguardava atendimento, a isso podemos acrescentar que o número máximo de entidades atendidas era de 17. Atualmente está unidade está praticando um tempo médio de processo de 19,48 minutos com um tamanho máximo de fila na ordem das 10 entidades que aguardam atendimento e como saída máxima há um total de 72 entidades atendidas, realizando uma comparação com este último dado, houve um aumento de $423,53 \%$, na quantidade de entidades atendidas, e simultaneamente ocorreu um aumento de $500 \%$ das entidades em espera. Nesse cenário houve um considerável aumento nas quantidades de paletes movimentados entre a UL e as UV, o que 
sustentou um aumento no quadro de funcionários da equipe vermelha, para que pudesse dar conta do volume de mercadorias movimentadas.

O processo de fiscalização será analisado considerando a média das três UVs. Considerando que esse processo anteriormente a esta proposta, possuía uma média de tempo na ordem de 1,62 minutos, tendo como média uma entidade que esperava por atendimento como tamanho máximo de fila, a isso acrescentamos que a média no número máximo de entidades atendidas era de 19. Atualmente estas unidades estão praticando um tempo médio de processo de 46,31 minutos com um tamanho máximo de fila que gira em média 2,67 entidades que ainda aguardam por atendimento e como saída máxima há uma média total de 75 entidades atendidas, realizando uma comparação com este último dado, houve um aumento de 394,74\%, na quantidade de entidades atendidas, e simultaneamente ocorreu um aumento de $266,67 \%$ das entidades em espera.
O processo de limpeza da área de transito na loja dois apresentava uma fila de 71,24 minutos com 1 entidade em espera com um número total de saídas na ordem de 8 entidades e atualmente está apresentando um tempo de fila de 23,84 minutos, uma redução de $66,54 \%$ tendo 5 entidades em espera e com saída máxima de 24 entidades, cujo valor representa $300 \%$ de aumento no número de saídas, a loja três apresentava uma fila de 28,42 minutos com 1 entidade em espera com um número total de saídas na ordem de 9 entidades e atualmente está apresentando um tempo de fila de 16,83 minutos, uma redução de $40,78 \%$ tendo 4 entidades em espera e com saída máxima de 23 entidades, cujo valor representa $255,56 \%$ de aumento, a loja um apresentava uma fila de 2,69 minutos com 1 entidade em espera com um número total de saídas na ordem de 5 entidades e atualmente está apresentando um tempo de fila de 8,26 minutos, uma aumento de 67,43\%, tendo 3 entidades em espera e com saída máxima de 16 entidades, cujo valor representa $320 \%$ de aumento.

Figura 4 - Relatório da utilização de cada recurso no cenário atual.

\begin{tabular}{|c|c|c|c|c|c|c|}
\hline \multicolumn{7}{|l|}{ Recursos Utilizados } \\
\hline Utilização Instantânea & Média & $\begin{array}{c}\text { Intervalo de } \\
\text { Confiança }\end{array}$ & Média Minima & Média Máxima & Valor Minimo & Valor Máximo \\
\hline EQUIPE DAUL & 0.06076447 & 0 & 0.05876196 & 0.06451489 & 0.00 & 1.00 \\
\hline LOJA 1 EQUIPE AZUL & 0.03963657 & 0,04 & 0.00 & 0.07624252 & 0.00 & 1.00 \\
\hline LOJA 1 EQUIPE VERMELHA & 0.3305 & 0,14 & 0.2111 & 0.4542 & 0.00 & 1.00 \\
\hline LOJA 1 FISCAL PREVENCAO & 0.03439144 & 0,02 & 0.02049559 & 0.04880161 & 0.00 & 1.00 \\
\hline LOJA2 EQUIPE AZUL & 0.0952 & 0,07 & 0.02379963 & 0.1854 & 0.00 & 1.00 \\
\hline LOJA2 EQUIPE VERMELHA & 0.3989 & 0,05 & 0.3373 & 0.4289 & 0.00 & 1.00 \\
\hline LOJA 2 FISCAL PREVENCAO & 0.04062479 & 0,01 & 0.03405625 & 0.05005101 & 0.00 & 1.00 \\
\hline LOJA 3 EQUIPE AZUL & 0.05244972 & 0,02 & 0.03636482 & 0.07406328 & 0.00 & 1.00 \\
\hline LOJA 3 EQUIPE VERMELHA & 0.5038 & 0,15 & 0.3486 & 0.6592 & 0.00 & 1.00 \\
\hline LOJA 3 FISCAL PREVENCAO & 0.04796393 & 0,01 & 0.03482118 & 0.06157474 & 0.00 & 1.00 \\
\hline MOTORISTA UL 1 & 0.00088447 & 0 & 0.00014530 & 0.00165274 & 0.00 & 1.00 \\
\hline MOTORISTA UL 2 & 0.00112799 & 0 & 0.00 & 0.00300727 & 0.00 & 1.00 \\
\hline MOTORISTA UL 3 & 0.00189125 & 0 & 0.00131981 & 0.00299779 & 0.00 & 1.00 \\
\hline MOTORISTA UL 4 & 0.00284726 & 0 & 0.00111964 & 0.00532395 & 0.00 & 1.00 \\
\hline MOTORISTA UL 5 & 0.00119387 & 0 & 0.00 & 0.00259951 & 0.00 & 1.00 \\
\hline MOTORISTA UL 6 & 0.00296646 & 0 & 0.00037278 & 0.00432197 & 0.00 & 1.00 \\
\hline MOTORISTA UL 7 & 0.00290750 & 0 & 0.00125976 & 0.00434672 & 0.00 & 1.00 \\
\hline MOTORISTA UL 8 & 0.00269619 & 0 & 0.00110277 & 0.00480777 & 0.00 & 1.00 \\
\hline MOTORISTA UL 9 & 0.00101749 & 0 & 0.00088025 & 0.00125386 & 0.00 & 1.00 \\
\hline MOTORISTA UL 10 & 0.00238137 & 0 & 0.00108951 & 0.00446268 & 0.00 & 1.00 \\
\hline MOTORISTA UL 11 & 0.00180338 & 0 & 0.00 & 0.00375113 & 0.00 & 1.00 \\
\hline MOTORISTA UL 12 & 0.00337002 & 0 & 0.00186596 & 0.00546817 & 0.00 & 1.00 \\
\hline
\end{tabular}

Fonte: Os próprios autores (2018). 
Figura 5 - Relatório da utilização de cada recurso no cenário proposto.

\begin{tabular}{|c|c|c|c|c|c|c|}
\hline \multicolumn{7}{|c|}{ Recursos Utilizados } \\
\hline Utilização Instantânea & Média & $\begin{array}{c}\text { Intervalo de } \\
\text { Confiança }\end{array}$ & Média Minima & Média Máxima & Valor Minimo & Valor Máximo \\
\hline EQUIPE DA UL & 0.3284 & $<0,00$ & 0.3101 & 0.3516 & 0.00 & 1.00 \\
\hline LOJA 1 EQUIPE AZUL & 0.2094 & $<0,01$ & 0.04935402 & 0.3930 & 0.00 & 1.00 \\
\hline LOJA 1 EQUIPE VERMELHA & 0.7024 & $<0,01$ & 0.4975 & 0.9064 & 0.00 & 1.00 \\
\hline LOJA 1 FISCAL PREVENCAO & 0.2113 & $<0,00$ & 0.1459 & 0.2696 & 0.00 & 1.00 \\
\hline LOJA 2 EQUIPE AZUL & 0.3752 & $<0,02$ & 0.1420 & 0.7430 & 0.00 & 1.00 \\
\hline LOJA 2 EQUIPE VERMELHA & 0.7128 & $<0,01$ & 0.5618 & 0.9292 & 0.00 & 1.00 \\
\hline LOJA 2 FISCAL PREVENCAO & 0.2037 & $<0,00$ & 0.1524 & 0.2721 & 0.00 & 1.00 \\
\hline LOJA 3 EQUIPE AZUL & 0.3638 & $<0,01$ & 0.1674 & 0.5891 & 0.00 & 1.00 \\
\hline LOJA 3 EQUIPE VERMELHA & 0.7983 & $<0,01$ & 0.6208 & 0.9430 & 0.00 & 1.00 \\
\hline LOJA 3 FISCAL PREVENCAO & 0.2462 & $<0,00$ & 0.1856 & 0.3052 & 0.00 & 1.00 \\
\hline MOTORISTA UL 1 & 0.00825401 & $<0,00$ & 0.00360138 & 0.01560233 & 0.00 & 1.00 \\
\hline MOTORISTA UL 2 & 0.00762887 & $<0,00$ & 0.00302478 & 0.01673681 & 0.00 & 1.00 \\
\hline MOTORISTA UL 3 & 0.01412456 & $<0,00$ & 0.00356685 & 0.02433149 & 0.00 & 1.00 \\
\hline MOTORISTA UL 4 & 0.01411745 & $<0,00$ & 0.00548938 & 0.02660397 & 0.00 & 1.00 \\
\hline MOTORISTA UL 5 & 0.00756537 & $<0,00$ & 0.00321237 & 0.01311741 & 0.00 & 1.00 \\
\hline MOTORISTA UL 6 & 0.01051823 & $<0,00$ & 0.00433519 & 0.01793716 & 0.00 & 1.00 \\
\hline MOTORISTA UL 7 & 0.01424300 & $<0,00$ & 0.00634661 & 0.02564484 & 0.00 & 1.00 \\
\hline MOTORISTA UL 8 & 0.01484766 & $<0,00$ & 0.00633350 & 0.02805143 & 0.00 & 1.00 \\
\hline MOTORISTA UL 9 & 0.00761736 & $<0,00$ & 0.00321978 & 0.01407523 & 0.00 & 1.00 \\
\hline MOTORISTA UL 10 & 0.00797022 & $<0,00$ & 0.00339248 & 0.01513920 & 0.00 & 1.00 \\
\hline MOTORISTA UL 11 & 0.01296342 & $<0,00$ & 0.00437726 & 0.02698395 & 0.00 & 1.00 \\
\hline MOTORISTA UL 12 & 0.01535999 & $<0,00$ & 0.00689502 & 0.02392015 & 0.00 & 1.00 \\
\hline
\end{tabular}

Fonte: Os próprios autores (2018).

O processo de abertura de carretas na loja três apresentava uma fila de 8,22 minutos com 1 entidade em espera com um número total de saídas na ordem de 21 entidades e atualmente está apresentando um tempo de fila de 12,01 minutos, um aumento de $66,54 \%$ tendo 3 entidades em espera e com saída máxima de 73 entidades, cujo valor representa $347,62 \%$ de aumento no número de saídas, a loja dois apresentava uma fila de 4,21 minutos com 1 entidade em espera com um número total de saídas na ordem de 19 entidades e atualmente está apresentando um tempo de fila de 9,87 minutos, um aumento de $57,34 \%$ tendo 3 entidades em espera e com saída máxima de 77 entidades, cujo valor representa $405,26 \%$ de aumento, a loja um apresentava uma fila de 2,80 minutos com 1 entidade em espera com um número total de saídas na ordem de 17 entidades e atualmente está apresentando um tempo de fila de 9,64 minutos, uma aumento de $70,95 \%$, tendo 3 entidades em espera e com saída máxima de 75 entidades, cujo valor representa $441,18 \%$ de aumento.

A UL teve seus processos de carregamento e montagem de paletes afetado mediante a aplicação desta nova proposta, para melhor compreensão dos dados, primeiramente serão apresentados os tempos do processo de carregamento e posteriormente os tempos referentes à montagem dos paletes. Como proposto vale lembrar que o procedimento de carregamento no primeiro cenário não apresentava filas, com uma saída de 35,25 entidades atendidas, atualmente a UL apresenta um tempo médio para esse processo na ordem dos 1,36 minutos, tendo como tamanho máximo de fila sete entidades que aguardam atendimento, a isso podemos acrescentar que houve um considerável aumento no número máximo de entidades atendidas saindo de 35,25 para 186 entidades atendidas, ou seja, um crescimento de $531,43 \%$.

No tocante ao processo de montagem dos paletes está UL praticava um tempo médio de processo de 37,79 minutos com um tamanho máximo de fila na ordem das 30 entidades que aguardam atendimento, considerando os números apresentado mediante a apresentação da nova proposta, houve uma mudança no tempo médio de processo provocando uma redução de 36,48 minutos, ou seja, uma redução de $96,53 \%$ no tempo médio desse processo, já na quantidade entidades que aguardavam atendimentos houve uma redução de 28 entidades, que corresponde a 93,33\%. Em resumo isso mostra que a presente proposta proporcionou um maior envio de sortimentos às lojas. 


\section{CONSIDERAÇÕES FINAIS}

A partir dos relatórios notaram-se oportunidades de melhorias, pontos de estrangulamento (gargalos) que não foram notados anteriormente pelos tomadores de decisão, como no caso da unitização dos paletes na UL, onde o tamanho do lote estava gerando um alto percentual de ociosidade na equipe, e consequentemente refletindo nas UVs, que sofriam com um baixo fluxo de sortimentos. A partir da análise dos cenários propostos, notou-se que se houvesse uma redução no tamanho do lote unitizado pela equipe da UL, isso acarretaria uma melhoria no processo, tornando-o mais eficiente, impactando na redução do percentual de ociosidade dos recursos, na redução de filas e um aumento de entidades atendidas.

Vale aqui ressaltar que a análise final não representa a solução ótima para o problema, porém indica ao gestor de forma rápida quais são os pontos que requerem intervenção e a relação entre as diversas variáveis abordadas no processo.

\section{REFERÊNCIAS}

[1]. COSTA J. Otimizando sistemas, estudo de caso da empresa Biomecânica. (Tese de conclusão de curso de Logística, com ênfase em Transportes)- Faculdade de Tecnologia, Jahu, 2006.

[2]. FREITAS FILHO, P. J. Introdução à modelagem e simulação de sistemas. 2.ed. Florianópolis: Visual Books, 2008.

[3]. OLIVEIRA, C. S. Metodologia para utilização de simulação em projetos de manufatura enxuta. Dissertação - Escola de Engenharia da Universidade Federal de Minas Gerais, Belo Horizonte, 2008.

[4]. PRADO, D. Usando o Arena em Simulação. Belo Horizonte: Editora de Desenvolvimento Gerencial, 1999.
Desta forma conclui-se que o objetivo geral deste estudo foi alcançado, ou seja, a ferramenta fornece subsídios aos gestores no processo de tomada de decisão de um centro de distribuição e suas unidades de vendas.

Pode-se dizer que a simulação, através da ferramenta Arena $\circledast$, forneceu subsídios para o processo de tomada de decisão, por intermédio da análise de seus relatórios, indicadores e criação de cenários. Entretanto, no caso em estudo, há a necessidade de avaliar a viabilidade do cenário encontrado sobre o prisma da análise econômica e financeira para a empresa e também verificar se o arranjo físico atual suporta um aumento de equipamentos e de colaboradores.

Dessa forma, a fim de fazer uma análise mais detalhada, fica sugerido como trabalho futuro: um estudo que englobe os outros processos da organização onde os recursos utilizados no contrato analisado estão alocados. Podese também aumentar a complexidade da análise e investigar todo o processo produtivo da empresa.

[5]. PRADO, D. Usando o Arena em simulação. 3 ed. Belo Horizonte: Editora Falconi, 2010 .

[6]. PRADO, D. S. Teoria das Filas e da Simulação. Nova Lima (MG): INDG, 2006.

[7]. SANTOS, C. M. SANTOS, L. P. L. dos. Aplicação do método de simulação e software Arena em um processo de fabricação de displays para forno de micro-ondas. SIMPEP, 2016.

[8]. SILVA, E. M. L.; JUNIOR, J. L. R. Simulação de eventos discretos em projetos e processos: contribuições, desafios e limitações. In: XX Simpósio de Engenharia de Produção, BauruSP, 2013.

[9]. SZYMANKIEWCI, J., MCDONALD, J. \& TURNER, K., Solving business problems by simulation. Grã-Bretanha, McGraw-Hill Book Company, 1988. 


\section{Capítulo 7}

\section{A ESCALA SERVQUAL NA ANÁLISE DE QUALIDADE DA PRESTAÇÃO DE SERVIÇOS LOGÍSTICOS}

\section{Luciano da Silva Ferreira}

\section{Átila de Arruda Brito}

\section{Claudio Tadeu Pinheiro de Oliveira Roberto Kanaane}

Resumo: Este artigo tem como objetivo analisar o conhecimento dos profissionais de logística a respeito da Escala SERVQUAL, bem como identificar sua utilização pelas empresas nas quais atuaram ou atuam; buscou-se também verificar a importância das dimensões dessa escala para análise de qualidade na prestação de serviços logísticos. A partir de uma análise quanti-quali de uma Survey direcionada a profissionais de logística, pode-se considerar que há pouco conhecimento dos profissionais sobre a escala SERVQUAL; que existe restrito uso das cinco dimensões definidas na escala pelas empresas e que os profissionais concebem que as cinco dimensões deveriam ser utilizadas na análise de qualidade da prestação de serviços logísticos.

Palavras-chave: Sistemas Produtivos, prestação de serviços, qualidade, SERVQUAL. 


\section{INTRODUÇÃO}

Ofertar serviços com qualidade não é mais encarado como diferenciação, mas como condição de existência das organizações no mercado, não sendo mais tratada como estratégia de diferenciação; os programas de qualidade devem levar em consideração o significado de qualidade para o cliente. Compreender como os serviços são avaliados do ponto de vista do cliente também é de suma importância (SOUZA; GRIEBELER; GODOY, 2007)

O processo de avaliação é fator essencial nessa diferenciação, estudá-lo e propor o uso de melhores práticas passa a ser fator fundamental para a realização das atividades de prestação de serviços.

Callan (1994) afirma que existe uma dificuldade muito grande por parte do consumidor em especificar o nível de serviço exigido por ele; pois por vezes não há possibilidade de examiná-lo previamente e pode conter elementos profissionais que é difícil para o consumidor avaliar.

A avaliação da qualidade em serviços implica na análise de duas variáveis, ou seja: o serviço esperado e a expectativa do cliente com relação a ele, também é pautado o serviço percebido, o que foi entregue ao cliente no final do processo (GRÖNROOS, 1984). Uma das ferramentas reconhecidas para a análise da prestação de serviços é a escala SERVQUAL desenvolvida por Parasuraman, Zeithaml e Berry (1988), comparando a qualidade percebida com a qualidade esperada do serviço prestado.

Neste sentido questiona-se: A escala SERVQUAL é utilizada por empresas prestadoras de serviços Logísticos? Como modo de responder a essa pergunta, foi feita uma pesquisa quanti-quali que teve como instrumento uma Survey a profissionais que já atuaram ou ainda atuam na prestação de serviços logísticos com o objetivo de analisar o conhecimento dos profissionais de logística a respeito da Escala SERVQUAL, buscou-se também verificar se as empresas nas quais atuam ou atuaram fazem uso da escala e qual a relevância das dimensões dessa escala para análise de qualidade na prestação de serviços logísticos.

\section{REVISÃO DA LITERATURA}

Devido as suas características de muitas entradas e saídas intangíveis e por sua diversidade, os serviços são muito difíceis de serem definidos. Lovelock e Wright (1999) citam duas abordagens que capturam a essência da qualidade: a primeira é que o serviço envolve duas partes, onde há uma performance de uma ponta a outra, independentemente de estar vinculado ou não a um produto físico, pois o desempenho é intangível; a segunda define os serviços como atividades econômicas, as quais criam valor e fornecem benefícios aos clientes, ou seja, uma mudança desejada.

O serviço é normalmente de natureza intangível, inclui muitas variáveis que na maioria das vezes não podem ser controladas, tem como objetivo a busca pela satisfação do cliente, sendo esta a consequência da combinação de resultados sobre o que é entregue ao cliente mediante a experiência fornecida.

Toledo et al. (2017) destacam que conceituar serviços é um fenômeno complexo, dentre algumas definições, ressaltam que o serviço é um ato que uma parte oferece a outra (interface fornecedor serviço $x$ cliente ou bem de sua propriedade), de característica essencialmente intangível, vinculada ou não a um bem físico. Como existem serviços associados a bem físicos, o ideal é analisá-los através de uma escala de tangibilidade, pois alguns estão mais próximos ou não da intangibilidade. 
Figura 1 - Escala de Tangibilidade

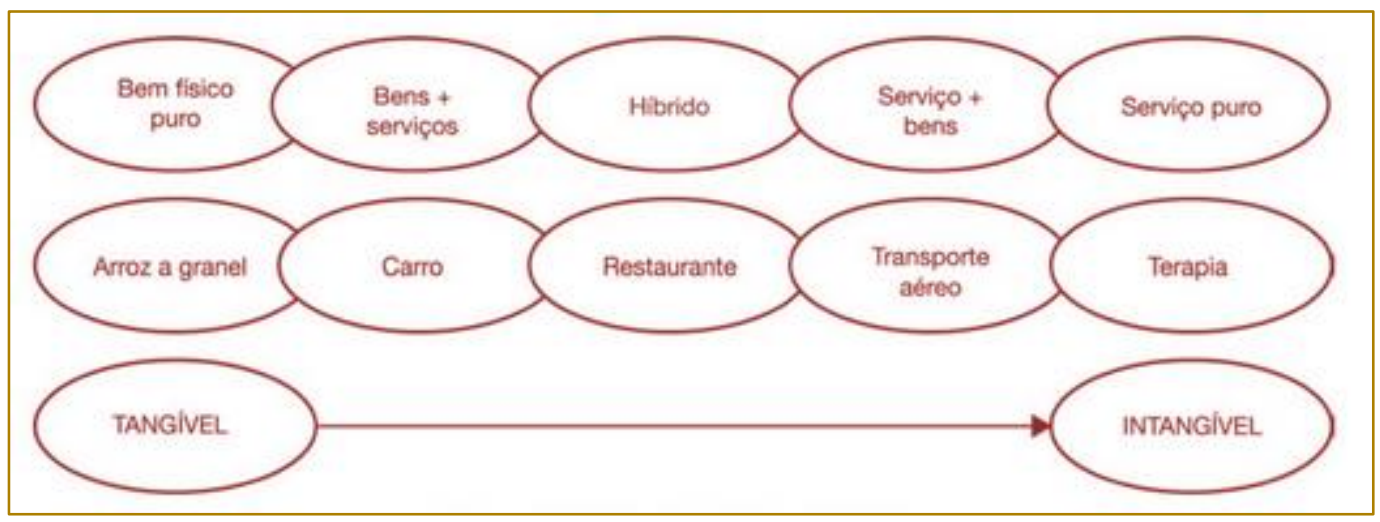

Fonte: Adaptado de Toledo (2017, p. 179)

Os serviços podem ser caracterizados como atos, ações, mesmo eles agregados ou não a um bem e sempre remetem a um sentimento por parte de seu consumidor, sua expectativa com relação ao serviço prestado. Eles podem ficar satisfeitos ou não, por isso, a qualidade em serviços deve levar em consideração o serviço em si e a percepção do cliente para com o mesmo (LAS CASAS, 2008).

A satisfação dos clientes está ligada à qualidade do serviço prestado, de acordo com Juran e Godfrey (1998) existem dois sentidos para a palavra qualidade, no primeiro 0 produto precisa atender as necessidades de seu cliente, nesse caso, a qualidade está focada na geração de renda e o objetivo é oferecer algo de qualidade maior, superior, com isso, será necessário (geralmente) um investimento acentuado, aumentando os custos, ou seja, maior qualidade, maior preço. No segundo a qualidade é orientada para custos, a qualidade tem o sentido de ser livre de deficiências, evitando falhas de campo, retrabalhos e reivindicações dos clientes, nesse caso, a qualidade superior custa menos.

A qualidade teve o seu início nas indústrias que sentiram, num primeiro momento, o peso da concorrência, do mercado acirrado, principalmente as que pensavam em exportação; posteriormente, o setor de serviços também se sentiu obrigado a investir em qualidade devido ao aumento de competitividade, porém com um intuito, a diferenciação, visando se destacar para os clientes.

Quando se fala em qualidade de um produto físico, ela pode ser mensurada através de indicadores variados, de muitas maneiras, já a qualidade no serviço enfrenta alguns obstáculos, pois se trata de natureza abstrata. Nos serviços, a identificação da qualidade se inicia antes da entrega do produto (serviço realizado), os clientes desenvolvem percepções durante todo processo de execução dos serviços e posteriormente comparam com suas expectativas (RUYTER, 1997).

A qualidade em serviços é percebida ao longo de sua prestação, não somente no final, isso pode envolver o atendimento, aspectos como aparência das pessoas envolvidas, cortesia, proatividade, entre outros. De acordo com o contato do cliente com as pessoas que the prestam serviços, pode haver vantagens e desvantagens, como exemplo é possível citar que quanto menor o contato, maior a possibilidade de "mecanização" dos serviços (serviços de telefonia, por exemplo), e quanto maior, existe a possibilidade de personalização.

Bolton e Drew (1991) afirmam que os clientes tendem a mudar sua avaliação global na qualidade do serviço em virtude das mudanças no desempenho ao longo do serviço prestado e também sofrem a influência de suas expectativas sobre o mesmo.

A expectativa de um cliente com relação ao serviço também sofre influências de experiências anteriores que tenha passado (GRÖNROOS, 1984), já a satisfação do cliente com o serviço prestado não está necessariamente relacionada a qualidade do serviço em si, ela possui influência maior nas intenções de compra do que a qualidade por si própria, como preço, o tempo de entrega ou a disponibilidade, por exemplo, podem aumentar a satisfação do cliente sem mudar 
sua percepção de qualidade do serviço (CRONIN e TAYLOR, 1992).

Parasuraman, Zeithaml e Berry (1988) entendem que a qualidade de um serviço pode ser medida comparando a qualidade percebida com a qualidade esperada do serviço prestado, para esta comparação eles desenvolveram uma escala chamada SERVQUAL, onde através de cinco dimensões poderia ser medida a qualidade da prestação de serviços.

Dimensões segundo a escala SERVQUAL, (PARASURAMAN; ZEITHAML; BERRY, 1988, p.23):

Elementos tangíveis: instalações físicas, equipamentos e aparência da equipe

Confiabilidade: capacidade de entregar o serviço prometido com confiança e precisão;

Utilidade: boa vontade para responder aos consumidores e oferecer um serviço rápido;

Segurança: competência e cortesia dos funcionários e sua capacidade de inspirar confiança;

Empatia: consideração, atenção individualizada que a empresa dá aos seus consumidores. (PARASURAMAN; ZEITHAML; BERRY, 1988, p.23)

Portanto, tais dimensões atuam como fatores facilitadores, visando apreender a essência dos serviços e a respectiva qualidade decorrente.

\section{DESENVOLVIMENTO DA TEMÁTICA}

Quanto aos fins, a presente pesquisa se caracteriza como descritiva, ao analisar o conhecimento dos profissionais de Logística sobre a escala SERVQUAL e analisar a efetividade do uso dessa escala por empresas na análise da prestação de serviços, mesmo que inconsciente, por meio da comparação de suas dimensões com o que é feito nas organizações. Conforme Vergara (2016) a pesquisa descritiva visa expor as características de um fenômeno ou de determinada população.

Essa pesquisa é caracterizada como uma pesquisa que contempla métodos mistos pois associa as formas qualitativa e quantitativa. É uma pesquisa quantitativa ao se utilizar métodos quantitativos para identificar a conhecimento das pessoas sobre o tema e posteriormente a utilização de métodos qualitativos na análise da utilização da escala pelas empresas.

Foi utilizada a técnica de coleta de dados denominada Survey, de amostra não probabilística e de característica acidental, com disponibilização por redes sociais da pesquisa, só foram consideradas as respostas de profissionais que atuam ou já atuaram na prestação de Serviços Logísticos. Obteve-se 38 respostas voluntárias e com aceite do termo de consentimento livre e esclarecido, dessas respostas 5 foram desconsideradas por não terem experiência profissional na área de Logística. A coleta de dados se deu no período entre 06/03/2018 e 05/04/2018.

A pesquisa contou com perguntas fechadas de modo a categorizar o público respondente, identificar se atuava ou já havia atuado na prestação de serviços logísticos, em qual área de atuação, se em suas atividades ou empresa havia a análise de qualidade, quais subitens das 5 dimensões de qualidade da escala SERVQUAL eram analisados, o conhecimento dos profissionais sobre a escala SERVQUAL, a importância da análise das dimensões e uma questão aberta para obter opiniões dos profissionais acerca do tema

\section{RESULTADOS E DISCUSSÃO}

A partir da análise das repostas ao questionário, foi possível identificar o conhecimento dos profissionais sobre o tema, - uso da escala SERVQUAL em suas atividades e a importância que eles atribuem às dimensões da qualidade definidas por essa escala. Os resultados da pesquisa são apresentados a seguir.

Quanto ao conhecimento sobre a Escala SERVQUAL, 6 dos respondentes ou seja 18\% da amostra (gráfico 1), conhecem essa escala, o que demonstra que a mesma é pouco difundida entre os profissionais de logística aqui no Brasil, pois a maioria $82 \%$ não a conhecem. 
Gráfico 1: Profissionais que conhecem a escala SERVQUAL:

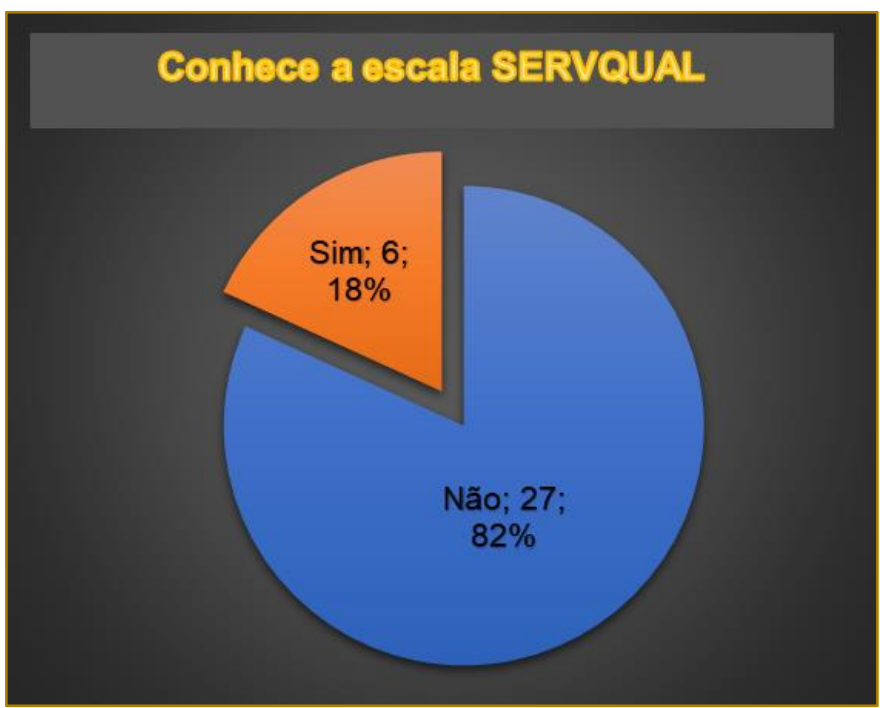

Fonte: Autores

Ao se estratificar o resultado por nível de escolaridade (gráfico 2), percebe-se que os profissionais que conhecem a escala SERVQUAL se concentram nos níveis de escolaridade de pós-graduação e ensino superior completo, o que pode indicar que o contato com esse tipo de avaliação ocorre na percepção de respondentes que possuem níveis superiores de ensino.

Gráfico 2: Estratificação por nível de escolaridade:

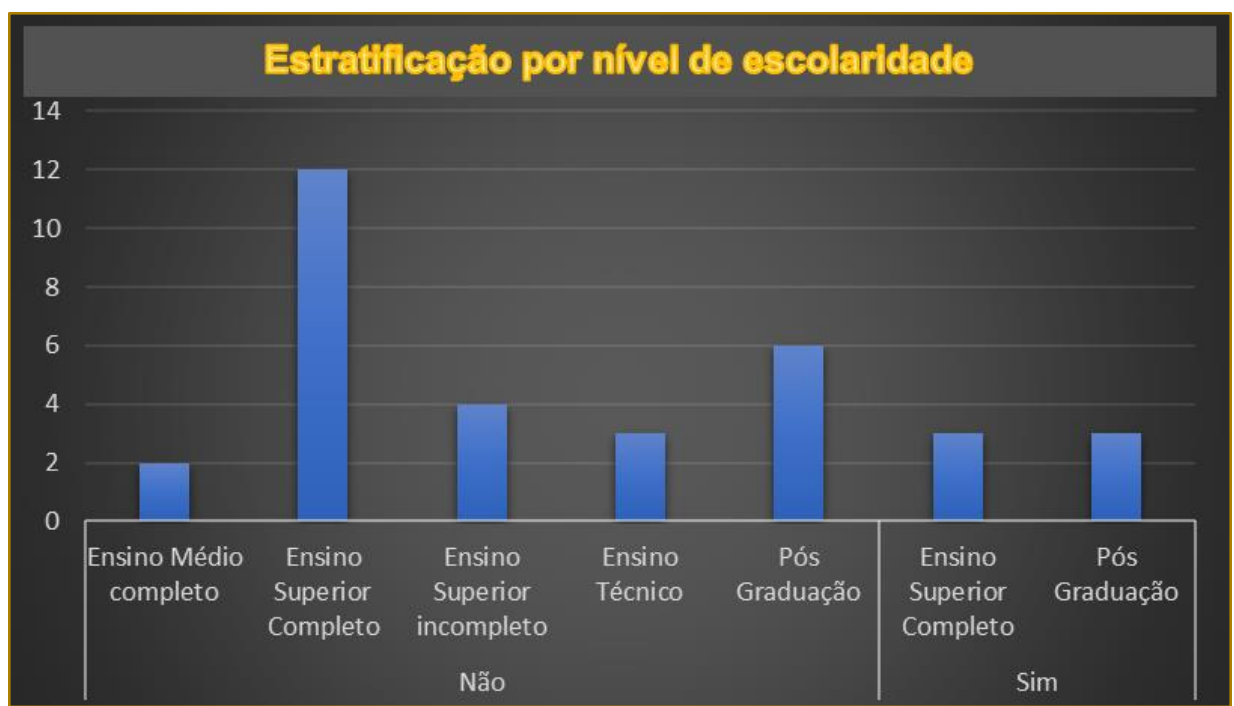

Fonte: Autores

Ao analisar as áreas de atuação dos profissionais na prestação de serviços logísticos (gráfico 3), identifica-se uma dispersão em 10 atividades diferentes, com uma concentração de profissionais nos setores de transporte, expedição e administrativo com um total de 21 respondentes 0 que equivale a aproximadamente $64 \%$ da amostra; pode-se deduzir com esses dados que os setores de atividades logísticas foram representados em sua maioria. 
Gráfico 3: Áreas de atuação dos profissionais:

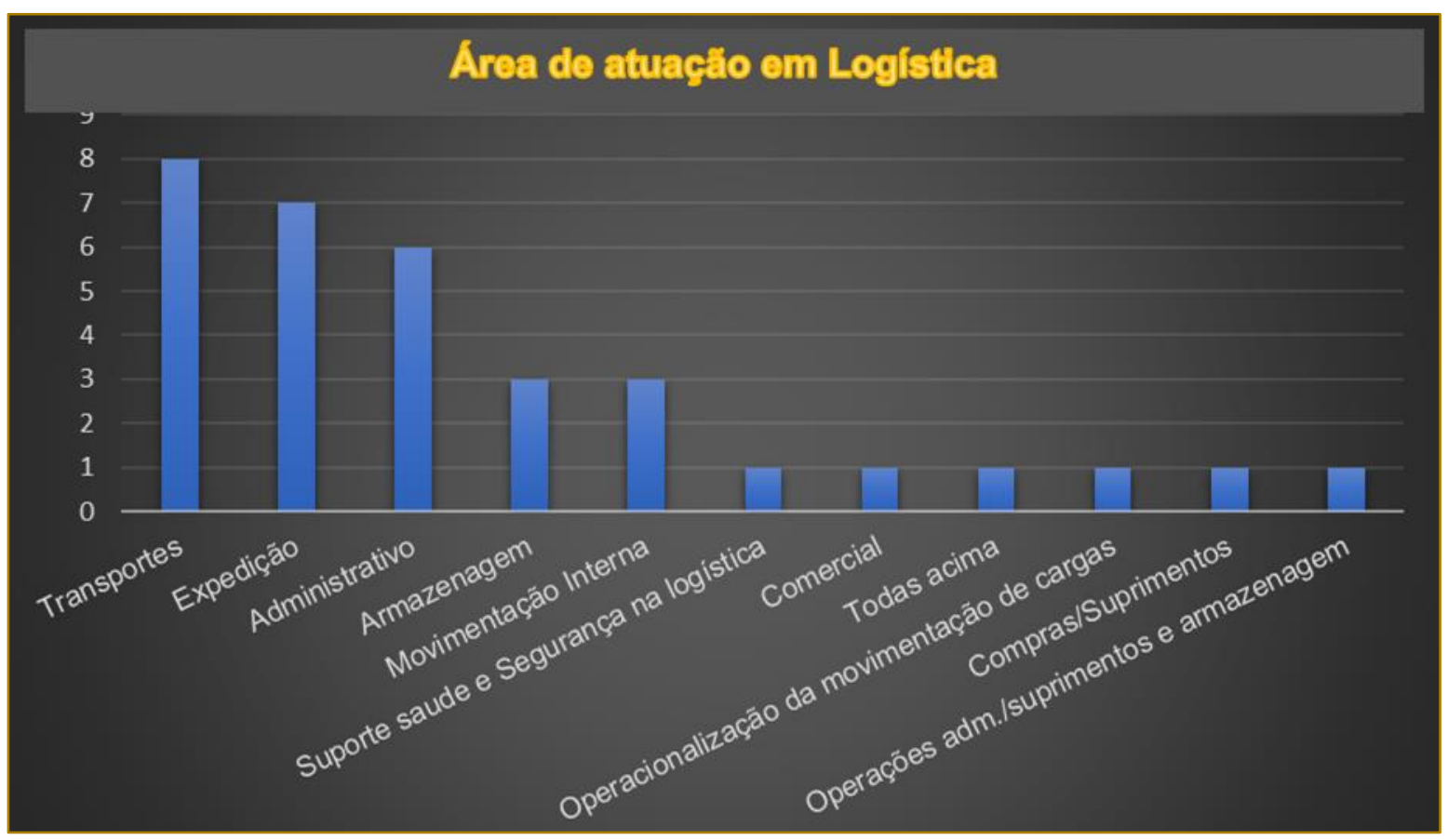

Fonte: Autores

Percebe-se ainda uma preocupação com a análise de qualidade dos serviços prestados (gráfico 4), $82 \%$ da amostra (27 respondentes) responderam que em suas atividades existe ou já existiu a análise da qualidade dos serviços logísticos.

Gráfico 4: Realiza ou realizou a análise de qualidade dos serviços

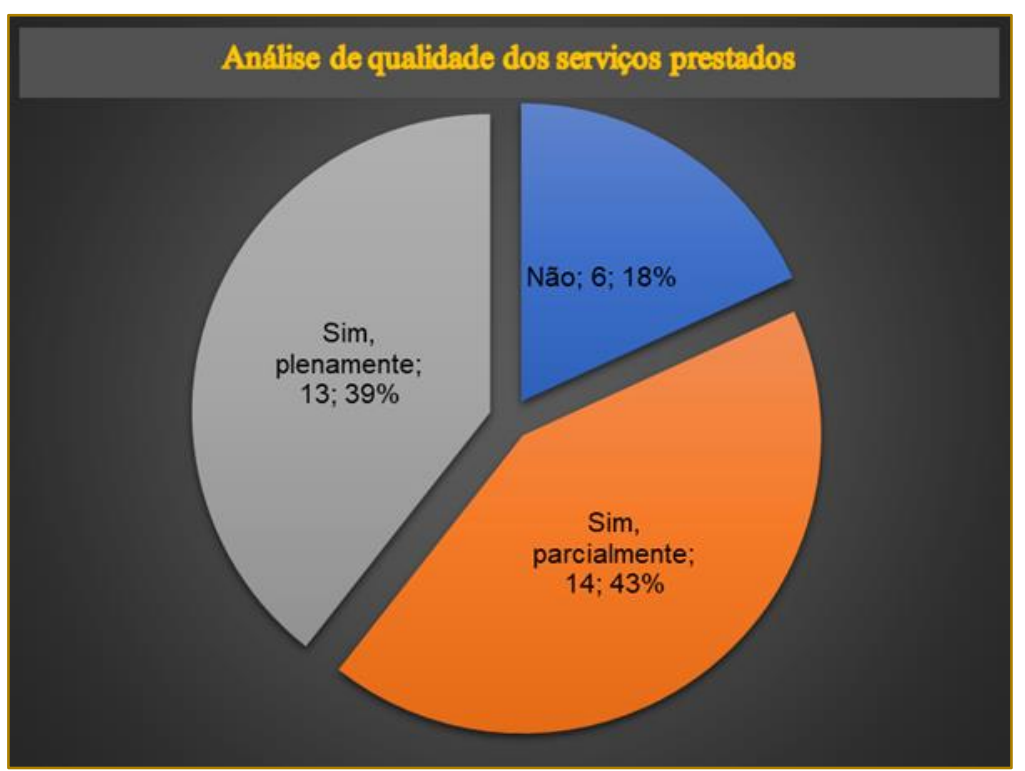

Fonte: Autores

Para verificar a possibilidade de uso da escala SERVQUAL na análise da prestação de serviços logísticos, as cinco dimensões dessa escala: Elementos Tangíveis; Confiabilidade; Utilidade; Segurança e
Empatia, foram subdivididas em subitens de análise da qualidade e submetidas para avaliação daqueles profissionais que responderam positivamente se faziam ou já 
haviam feito análise de qualidade dos serviços.

No gráfico 5 é analisada a dimensão Elementos Tangíveis, a partir dos subitens Aparência da equipe; Qualidade de equipamentos e Qualidade das instalações físicas. Percebe-se pelos resultados que há pouca preocupação com a análise dessa dimensão pelas empresas, com um índice baixo (26\% na melhor situação); dentre os subitens pode-se ainda inferir que há uma maior atenção com a qualidade de instalações físicas e equipamentos do que com a aparência da equipe.

Gráfico 5: Análise de Qualidade na dimensão Elementos Tangíveis

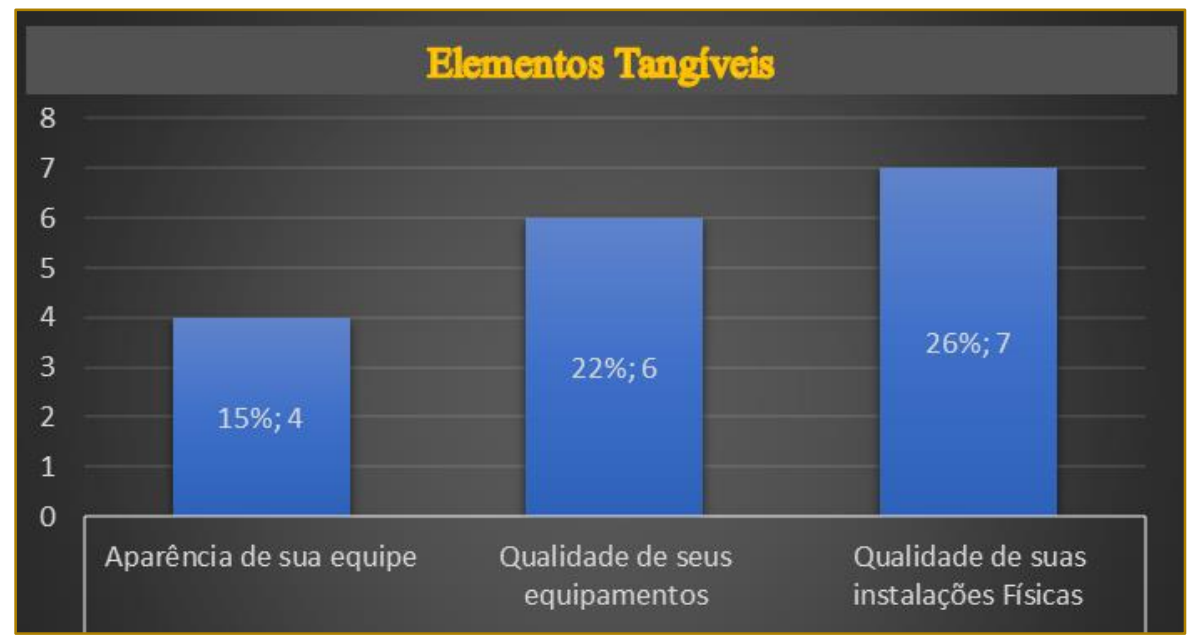

Fonte: Autores

Outra dimensão analisada foi a Confiabilidade, nela foram apreciados os subitens Condições de entrega de acordo com o solicitado pelo cliente e cumprimento do prazo de entrega combinado com o cliente, respectivamente obteve-se 59\% e $63 \%$ de respostas positivas quanto a análise desses subitens (gráfico 6), atestando a importância atribuída pelas empresas a essa dimensão.

Gráfico 6: Análise de Qualidade na dimensão Confiabilidade

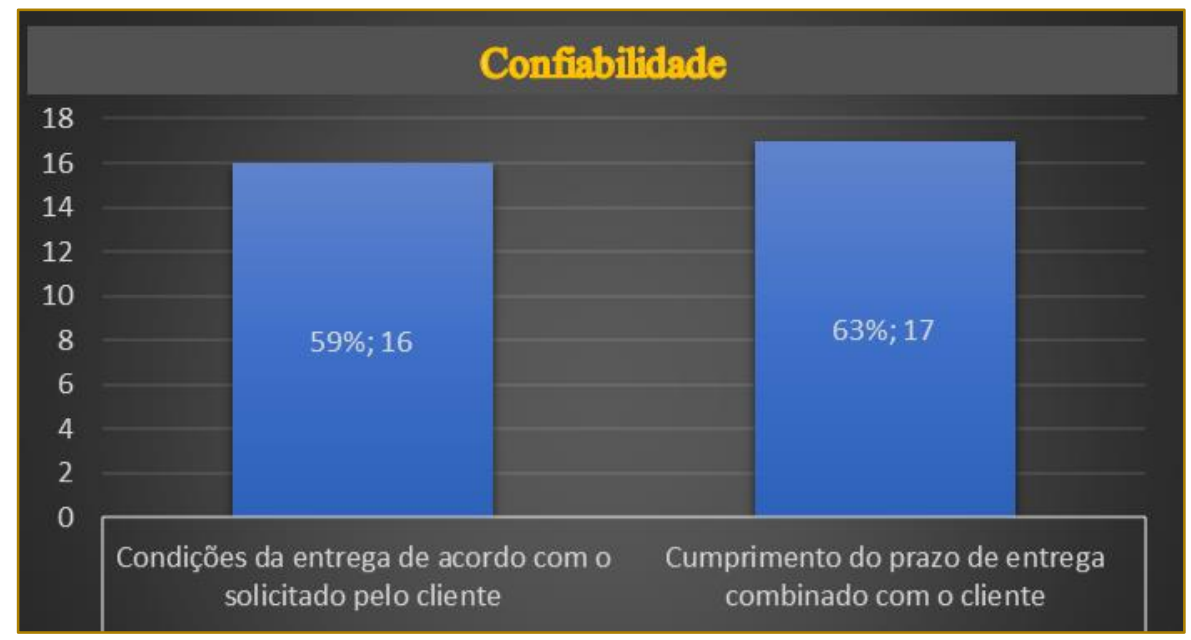

Fonte: Autores

Com os subitens Atenção dada ao cliente e Consideração dos funcionários pelo cliente, foi analisada a dimensão Empatia, percebe-se assim como na dimensão Elementos Tangíveis uma baixa análise dos subitens, com apenas $26 \%$ e $22 \%$ (gráfico 7 ). 
Gráfico 7: Análise de Qualidade na dimensão Empatia

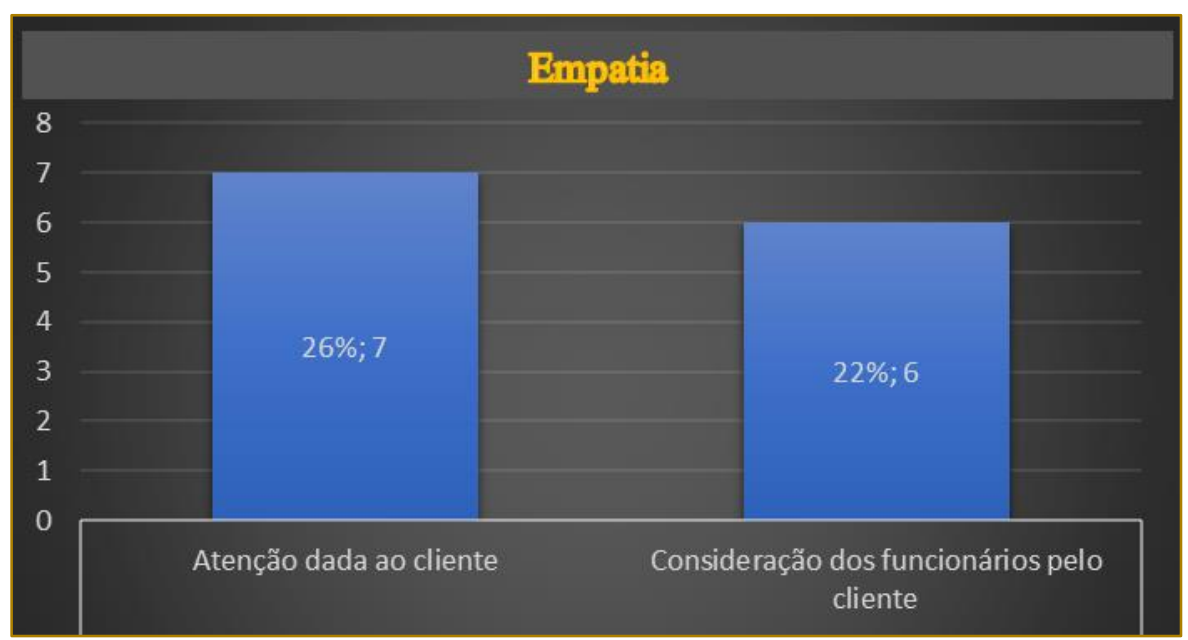

Fonte: Autores

No Gráfico 8 apresenta-se a análise dos subitens Capacidade dos funcionários em inspirar confiança, competência e cortesia dos funcionários, que fazem parte da dimensão Segurança na escala SERVQUAL.
Constatou-se que o elemento competência dos funcionários foi analisado em 30\% das respostas e que os outros dois subitens obtiveram um percentual muito baixo $(7 \%$ e $11 \%)$.

Gráfico 8: Análise de Qualidade na dimensão Segurança

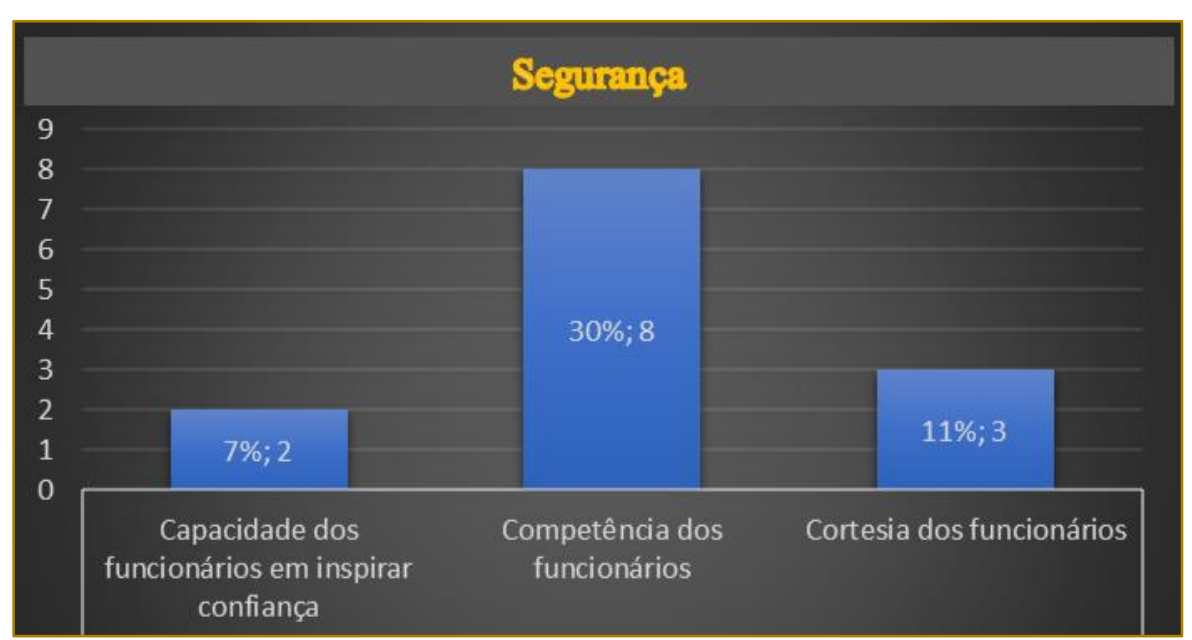

Fonte: Autores

A dimensão Utilidade também foi analisada (gráfico 9), evidenciando uma preocupação com a velocidade nas respostas/atendimento ao cliente por mais da metade dos respondentes $(59 \%)$ e de quase a metade quanto às respostas dadas ao cliente $(48 \%)$. 
Gráfico 9: Análise de Qualidade na dimensão Utilidade

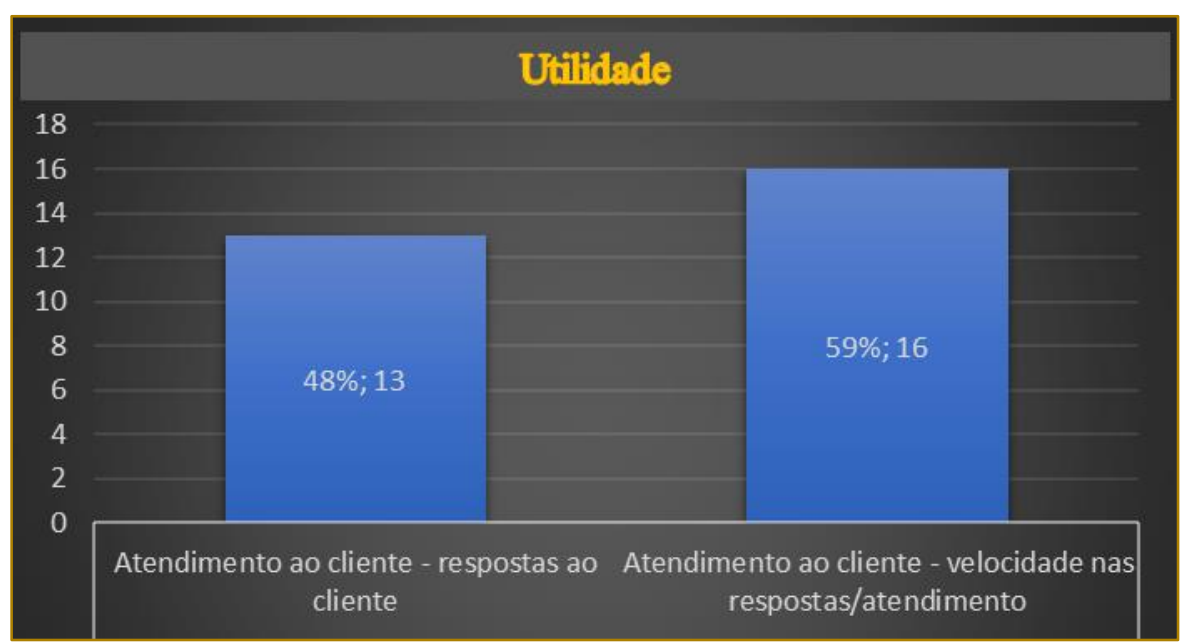

Fonte: Autores

Ainda foi verificado o quanto os respondentes entendem ser importante analisar a qualidade dos serviços logísticos a partir de cada uma das dimensões estudadas, utilizando-se de uma escala baseada na escala Likert com cinco dimensões, sendo a primeira não é importante e a última muito importante, todos os trinta e três inquiridos com respostas validas assinalaram a importância de cada uma das dimensões de acordo com os seus significados, conforme definição:

- Elementos tangíveis: instalações físicas, equipamentos e aparência da equipe

- Confiabilidade: capacidade de entregar o serviço prometido com confiança e precisão;

- Utilidade: boa vontade para responder aos consumidores e oferecer um serviço rápido;
- Segurança: competência e cortesia dos funcionários e sua capacidade de inspirar confiança;

- $\quad$ Empatia: consideração, atenção individualizada que a empresa dá aos seus consumidores. (PARASURAMAN; ZEITHAML; BERRY, 1988, p.23)

Percebe-se pela tabela 1 que todas as dimensões tiveram resultados acima de $88 \%$ considerando como importante ou muito importante sua análise, o que demonstra que os profissionais concebem que a análise de qualidade das 5 dimensões necessita ser feita pelas empresas que prestam serviços logísticos.

Tabela 1 - Análise da importância atribuída às dimensões da escala SERVQUAL

\begin{tabular}{|l|c|c|c|c|c|c|}
\hline & $\begin{array}{c}\text { Não é } \\
\text { importante }\end{array}$ & $\begin{array}{c}\text { Pouco } \\
\text { Importante }\end{array}$ & $\begin{array}{c}\text { Razoavelmente } \\
\text { Importante }\end{array}$ & $\begin{array}{c}\text { Muito } \\
\text { Importante }\end{array}$ & $\begin{array}{c}\text { \% importante e } \\
\text { muito importante }\end{array}$ \\
\hline Elementos Tangíveis & 1 & 2 & 1 & 14 & 15 & $88 \%$ \\
\hline Confiabilidade & 1 & 1 & 0 & 4 & 27 & $94 \%$ \\
\hline Utilidade & 1 & 1 & 1 & 9 & 21 & $91 \%$ \\
\hline Segurança & 1 & 1 & 2 & 11 & 18 & $88 \%$ \\
\hline Empatia & 1 & 1 & 1 & 13 & 17 & $91 \%$ \\
\hline
\end{tabular}

Fonte: Autores

Relacionando a Tabela 01 com os gráficos 5 a 9, dimensão Confiabilidade com 94\% de avaliação positiva na tabela, também é a dimensão mais utilizada com 59\% e 63\% de utilização (gráfico 6). 
É possível inferir a partir dos dados apresentados, que há pouco conhecimento sobre a escala SERVQUAL por parte dos profissionais de Logística, também constatase que apenas as dimensões Confiabilidade e Utilidade são utilizadas na análise de qualidade da prestação de serviços logísticos pelo público analisado, em contrapartida os profissionais entendem que todas as dimensões deveriam ser analisadas.

\section{CONSIDERAÇÕES FINAIS}

A análise da qualidade na prestação de serviços é algo rotineiro pelos profissionais de Logística, conforme identificado pela presente pesquisa onde $82 \%$ dos respondentes fazem ou já fizeram a análise da qualidade dos serviços logísticos prestados.

Respondendo à questão de pesquisa: A escala SERVQUAL é utilizada por empresas prestadoras de serviços Logísticos? Identificou-se que a escala SERVQUAL não é plenamente utilizada pelas empresas prestadoras de serviços logísticos, com dimensões como Elementos Tangíveis e Empatia com no máximo 26\% de utilização de seus subitens na avaliação de qualidade e ao analisar os subitens de todas as cinco dimensões encontra-se, por exemplo, a análise da capacidade dos funcionários em

\section{REFERÊNCIAS}

[1]. BOLTON, R. N.; DREW, J. H.; A Longitudinal Analysis of the Impact of Service Changes on Customer Attitudes. Journal of Marketing. Jan. 1991. p. 1-9

[2]. CALLAN R. J. Quality Assurance Certification for Hospitality Marketing, Sales and Customer Services, The Service Industries Journal. 1994. 14:4, 482-498.

[3]. CRONIN Jr, J. J.; TAYLOR S.; A. Measuring Service Quality: A Reexamination and Extension. Journal of Marketing. Jul. 1992. p. 55-68

[4]. GRÖNROOS, C..; A Service Quality Model and its Marketing Implications. European Journal of Marketing Vol. 18. 1984. P. 36-44.

[5]. JURAN, J. M.; GODFREY, A. B.; Juran's quality handbook 5 ed. New York, New York (USA). McGraw-Hill, 1998.

[6]. LAS CASAS, A. L.; Qualidade total em serviços: conceitos, exercícios, casos práticos -6 . ed. São Paulo (SP). Atlas, 2008. 223 p.

[7]. LOVELOCK, C. H.; WRIGHT, L.; Principles of Service Marketing and Management ed 2. Upper inspirar confiança que é um subitem da dimensão Segurança com apenas, $7 \%$ de aplicação.

Quanto aos objetivos da pesquisa em analisar o conhecimento dos profissionais de logística a respeito da Escala SERVQUAL e se as empresas com as quais atuam ou atuaram fazem uso da escala, mesmo que sem conhecimento da mesma e qual a importância das dimensões dessa escala para análise de qualidade na prestação de serviços logísticos, chegou-se à conclusão que apenas $18 \%$ dos profissionais de logística conhecem a escala SERVQUAL; por outro lado, as empresas fazem pouco uso das dimensões na análise de sua prestação de serviços logísticos, embora os profissionais consideram importante a análise das cinco dimensões da escala SERVQUAL.

Sugere-se a realização de pesquisas abrangendo um universo maior de respondentes comparando seus resultados com o da investigação atual, indica-se também a possibilidade de estudos sobre como utilizar empiricamente a escala SERVQUAL na análise de qualidade da prestação de serviços logísticos, possibilitando, dessa forma aferir eficiência nos serviços logísticos, denotando a qualidade como um atributo relevante.

Saddle River, New Jersey (USA). Prentice Hall, 1999.414 Páginas

[8]. PARASURAMAN, A.; BERRY, L. L. ; ZEITHAML, V.A. SERVQUAL: A Multiple-item Scale for Measuring Consumer Perceptions of Service Quality. Journal of Retailing, New York University, Spring, 1988, Vol64, Number 1, p. 12-40.

[9]. RUYTER K. Et al. Intern. Z of Research in Marketing 14. 1997. p 231-243

[10]. SOUZA, A. M.; GRIEBELER, D.; GODOY, L. P.; Qualidade na prestação de serviços fisioterápicos - estudo de caso sobre expectativas e percepções de clientes. Produção Vol. 17 n 3. 2007. P. 435-453.

[11]. VERGARA, S.C: Projetos e relatórios de pesquisa em administração.16 ed. São Paulo. Atlas, 2016

[12]. TOLEDO, J.C.; et al. Qualidade: gestão e métodos (reimp.). Rio de Janeiro (RJ). LTC, 2017. 397 


\section{Capítulo 8}

\section{ANÁLISE CRITTICA NO PROCESSO DE EMBARQUE DE PRODUTOS PERIGOSOS EM $U M$ AEROPORTO BRASILEIRO}

\section{Paulo Douglas Cavalcante da Silva}

\section{Eliacy Cavalcanti Lélis}

Resumo: Para a segurança e eficiência no fluxo de exportações de produtos perigosos, é de suma importância um conhecimento na regulamentação e normas pertinentes a esses embarques e o cumprimento das mesmas. Este artigo tem como objetivo analisar criticamente o embarque de produtos perigosos em um aeroporto brasileiro. A metodologia de pesquisa inclui pesquisa bibliográfica, documental e de campo com profissionais que lidam com consolidação de cargas e embarque de produtos perigosos em um aeroporto no Brasil. Foi constatado que há um número crescente de embarques rejeitados de produtos perigosos, também conhecidas popularmente na aviação como DG (Dangerous Good), devido a simples erros de posicionamento de marcações e etiquetas nos volumes. Foram indicadas informações e ações para orientar os embarcadores sobre a maneira correta de etiquetar e fazer a marcação desses produtos. Conclui-se que estas informações e ações indicadas podem minimizar ou evitar custos extras com o recheck é cobrado pelas companhias aéreas e reduzir o risco de eventual atraso do embarque por aguardar a correção da etiquetagem do volume, ocasionando a perda da reserva de espaço na aeronave para o devido embarque, no prazo pretendido inicialmente.

Palavras-chave: Artigos perigosos. Embarque. Transporte aéreo 


\section{INTRODUÇÃO}

A entrada, armazenagem, manuseio e principalmente 0 transporte de produtos perigosos em aeronaves civis ou cargueiras devem ser controladas em extrema precaução para que a segurança dos que estão a bordo e do meio ambiente sejam preservadas.

Com o crescimento na demanda do transporte aéreo nos últimos anos, torna-se cada vez mais complexa a sua fiscalização, ocorrendo maior frequência o armazenamento, manuseio e o transporte de forma irregular; que podem gerar acidentes, contaminação do meio ambiente, multas, processos judiciais e perdas financeiras, principalmente nos embarque de produtos perigosos.

É importante lembrar que produto perigoso é toda substância ou artigo que apresente características físicas e químicas que possam oferecer qualquer risco ou dano à saúde e segurança pública, ao estabelecimento e ao meio ambiente, conforme os critérios de classificação da ONU.

A segurança da carga, da tripulação e dos passageiros está diretamente ligado com os cuidados a serem tomados e seguidos conforme exige a International Air Transport Association (IATA), em português, Associação Internacional de Transportes Aéreo, com os artigos perigosos antes $e$ durante 0 carregamento, 0 embarque, 0 descarregamento e o manuseio do material. As recomendações aplicadas ao embarque de produtos perigosos nos aeroportos brasileiros precisam estar de acordo com as determinações da IATA, estando devidamente identificadas, classificadas, acondicionadas, embaladas, marcadas, etiquetadas, homologadas e com todos os documentos conforme estabelece o regulamento, para que imprevistos não ocorram. Sendo que, todos os envolvidos com atividade ficam responsáveis de certificar-se que as exigências e informações impostas foram cumpridas e se estão corretas e completas.

Esse artigo traz a reflexão sobre as dificuldades mais frequentes no processo de embarque de produtos perigosos quanto ao que diz respeito às marcações $e$ etiquetagens, exclusivamente para o transporte internacional aéreo. Nos casos de embarques rejeitados devidos a erros primários na disposição das etiquetas e marcações de produtos perigosos, o que pode ser feito para reduzir ou evitar esse problema, visando responder a seguinte pergunta: como reduzir os custos decorrentes de embarque rejeitado de produtos perigosos em um aeroporto brasileiro?

Para responder a esta pergunta, este artigo tem como objetivo geral realizar uma análise crítica dos embarques rejeitados de produtos perigosos em um aeroporto brasileiro visando a redução de custos decorrentes desse problema e a melhoria de desempenho desta atividade logística.

Os objetivos específicos desta pesquisa incluem: a) uma revisão bibliográfica sobre o transporte de produtos perigosos; b) a análise do processo de embarque em um aeroporto brasileiro realizado por uma empresa para identificação dos motivos da rejeição e dos custos decorrentes dessa rejeição; c) a recomendação de ações gerenciais e técnicas que podem reduzir ou evitar esse problema.

Devido ao aumento no fluxo de exportações de artigos perigosos, é de suma importância um conhecimento na regulamentação e normas pertinentes a esses embarques e o cumprimento das mesmas, pois, com a rapidez do transporte aéreo, cada vez mais tem sido utilizado esse modal para realizar o deslocamento de artigos perigosos.

Através desse artigo, pretende-se discutir a importância do cumprimento das formas mais corretas de realizar a devida etiquetagem e marcação, de maneira a promover o embarque de maneira segura, dentro dos padrões exigidos pela regulamentação IATA, dessa forma evitando acidentes e, consequentemente ajudando na preservação do meio ambiente, propriedades e seres humanos, assim, evitando também custos extras com os referidos embarques.

Os expedidores de cargas perigosas para o transporte internacional, poderão utilizar-se desse artigo como base de apoio, para tirar eventuais dúvidas mais comuns e frequentes, em relação as marcações e etiquetagem de artigos perigosos no modal aéreo.

\section{METODOLOGIA DE PESQUISA}

A metodologia adotada para 0 desenvolvimento desse estudo foi com a pesquisa com abordagem qualitativa e analítica na apresentação dos resultados, utilizando o método dedutivo. A análise e 
discussão considerou as teorias de referência da pesquisa bibliográfica e a pesquisa documental das normas e procedimentos com os produtos perigosos no transporte aéreo que são determinados IATA.

Foi conduzida uma pesquisa de campo em um aeroporto de São Paulo com o contato com profissionais de empresas de transporte aéreo e empresa consolidadora de cargas para exportação via aérea. A coleta de dados foi mediante realização de entrevista com o agente de cargas líder, responsável pelo controle de embarques de artigos perigosos de três grandes companhias aéreas e três colaboradores da empresa de consolidação de cargas, que por questões de discrição, não citaremos os nomes, afim de preservar os colaboradores e as empresas envolvidas.

\section{EMBASAMENTO TEÓRICO}

\subsection{LOGISTICA}

Segundo Novaes (2001), logística é o processo de planejar, agir, fazer e implementar um controle de forma eficiente do fluxo e a armazenagem de materiais, produtos ou mesmo serviços, sendo observado desde o seu ponto de origem até seu destino final. Portanto, o conceito de logística vem sendo aprimorado com o passar dos anos, as organizações vêm percebendo a importância de manter um processo logístico eficiente, investindo na capacitação de seus colaboradores, promovendo a competitividade frente ao mercado nacional e internacional.

Já para Dias (2009), logística é o sistema de administrar qualquer tipo de negócio de forma integrada e estratégica, com o planejamento e a coordenação das atividades para otimizar todos os recursos disponíveis e buscar o ganho global no processo no sentido operacional e financeiro.

Ballou (2006) explica que a logística considera todas as atividades de movimentação e armazenagem que estão relacionadas ao fluxo de produtos desde o ponto de aquisição da matéria-prima até ao ponto de consumo final.

Caixeta Filho e Martins (2001) dizem que os estudos na área de transportes são de fundamental importância na atual realidade da globalização, onde a logística tem um papel fundamental na política de desenvolvimento regional e nacional e na economia de um país.

De acordo Dias (2009), com a globalização dos mercados, cada vez mais o preço de venda, a qualidade do produto e a segurança são parâmetros com pouca faixa de "manobra", a competitividade estará em colocar o produto certo, ao menor preço, na qualidade correta, com total segurança para o cliente final. Essa cadeia de atendimento deverá estar integrada, de forma que seus custos não inviabilizem os negócios da empresa. Esse gerenciamento, que é a Administração de Materiais, está tomando uma forma mais ampla, com mais atribuições e responsabilidades, e vem sendo chamado de Logística.

\subsection{PRODUTOS PERIGOSOS}

O desenvolvimento econômico de uma sociedade conduz ao crescimento industrial de produtos perigosos, e o transporte é uma atividade fundamental para possibilitar a movimentação desses materiais (REAL apud ANDRADE NETO e OLIVEIRA NETTO, 2005).

De acordo Bellan e Pinto (2016), cargas perigosas são quaisquer cargas que, por serem explosivas, como os gases comprimidos ou liquefeitos, inflamáveis, oxidantes, venenosos, infectantes, radioativos, corrosivos ou poluentes, possam representar riscos aos trabalhadores, às instalações físicas e ao meio ambiente em geral, sendo pré-requisito essencial para a segurança do armazenamento, transporte e manuseio de cargas perigosas, a sua apropriada identificação, acondicionamento, etiquetagem, empacotamento e documentação.

Bellan e Pinto (2016) ainda citam que, produto ou artigo é considerado perigoso para o transporte quando o mesmo se enquadrar basicamente em uma das nove classes de produtos perigosos. Essa classificação é recomendada pela ONU - Organização das Nações Unidas, por isso é utilizada no mundo todo:

- $\quad$ Classe 1: explosivos;

- $\quad$ Classe 2: gases;

- Classe 3: líquidos inflamáveis;

- Classe 4: sólidos inflamáveis; substâncias sujeitas à combustão 
espontânea; substâncias que, em contato com a água, emitem gases inflamáveis;

- Classe 5: substâncias oxidantes; peróxidos orgânicos;

- Classe 6: substâncias tóxicas (venenosas); substâncias infectantes;
- Classe 8: corrosivos;

- Classe 9: substâncias perigosas diversas.

A Figura 1 mostra as etiquetas de risco pertinentes aos embarques de produtos perigosos.

- $\quad$ Classe 7: materiais radioativos;

Figura 1 - Etiquetas de risco

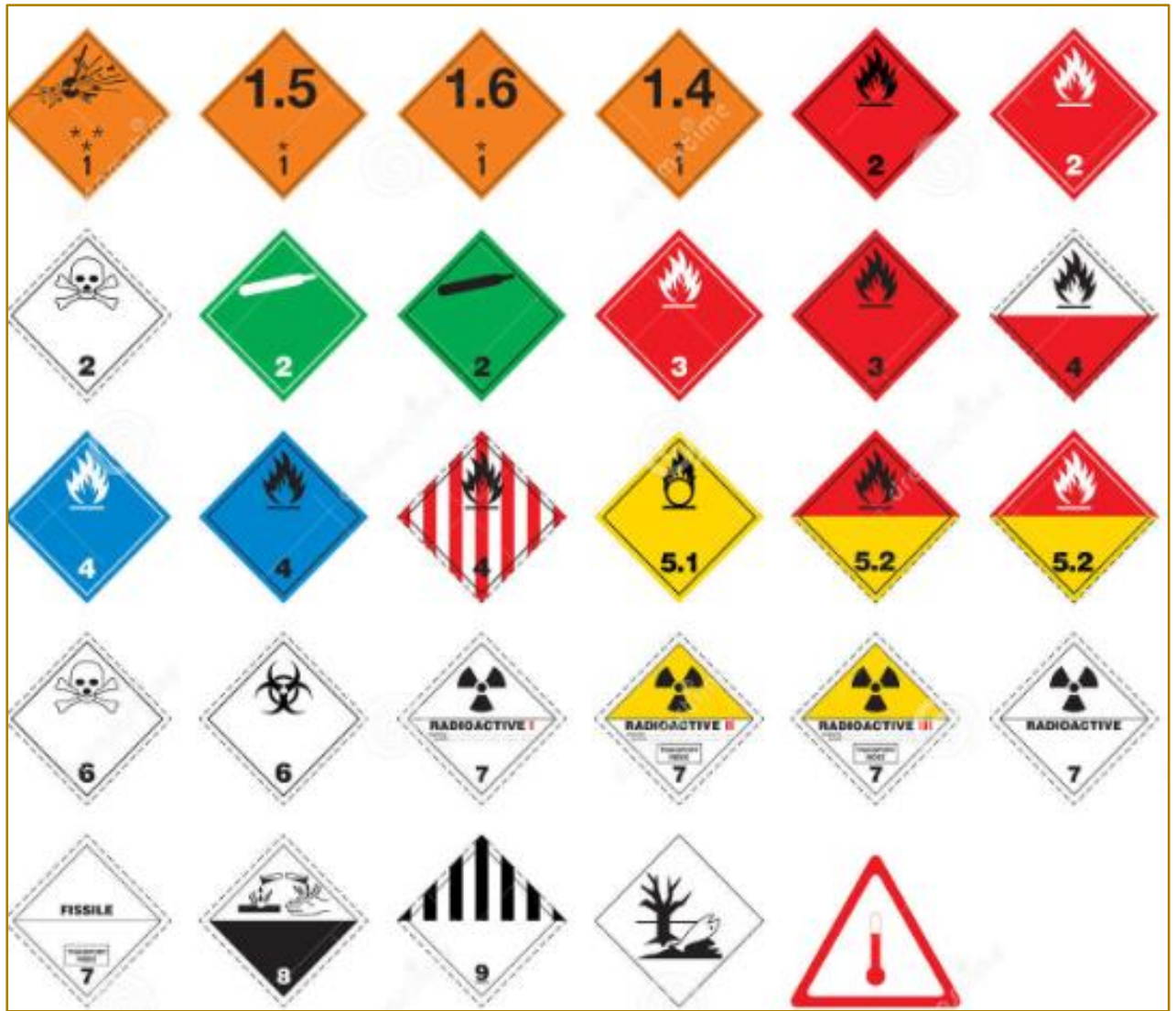

Fonte: Dreamstime (2018).

\subsection{REGULAMENTO DE PRODUTOS PERIGOSOS NO TRANSPORTE AÉREO}

$\mathrm{Na}$ década de 50, todas as linhas aéreas membros da IATA, perceberam a necessidade de aumentar o controle do transporte de mercadorias perigosas pelo ar, pois perceberam que caso não fossem controlados poderiam causar efeitos negativos na segurança de passageiros, tripulação e/ou aeronaves que transportavam esses artigos.

Experiências em outros modais de transportes já tinham demonstrado a possibilidade de transportar em segurança de substâncias ou artigos perigosos que estivessem propriamente embalados e a quantidade em cada embalagem. No transporte aéreo $70 \%$ dos incidentes ocorridos nos porões de aeronaves civis são provocados pelo transporte indevido de artigos perigoso, e destes, 30\% são diretamente relacionados à inadequalibilidade das embalagens, em descumprimento às normas internacionais da International Civil Aviation Organization (ICAO) e da IATA.

Segundo Ashford et al. (2015), a ICAO define norma da seguinte maneira: qualquer especificação de características físicas, materiais, de desempenho, de pessoal ou de procedimento, cuja aplicação uniforme é reconhecida como necessária para a segurança ou a regularidade da navegação 
aérea internacional e à qual os Estados contratantes se conformarão de acordo com a Convenção; no evento de impossibilidade de cumprimento, a notificação ao Conselho é compulsória segundo o Artigo 38. Normas, portanto, são especificações que são necessárias à navegação aérea internacional e, no caso de desvios, é compulsório notificar outros Estados contratantes. A ICAO define práticas recomendadas da seguinte maneira: Qualquer especificação de características físicas, de configuração, de material, de desempenho, de pessoal ou procedimento cuja aplicação uniforme é reconhecida como desejável e do interesse da segurança, regularidade ou eficiência da navegação aérea internacional, e a qual os Estados contratantes se esforçarão para cumprir, de acordo com a Convenção.

Práticas recomendadas, portanto, são consideradas especificações desejáveis que os Estados-membros se esforçarão para cumprir devidamente limitada. Usando as experiências de todos e o conhecimento das industrias envolvidas no transporte aéreo, a IATA desenvolveu a primeira regulamentação para o transporte de cargas perigosas via aérea. A primeira edição dessa regulamentação foi publicada em 1956.

A aplicação bem sucedida das regulamentações relativas ao transporte aéreo de artigos perigosos e a realização dos seus objetivos dependem da conscientização de todos os indivíduos, em relação aos riscos envolvidos nesse transporte. Isso somente poderá ser alcançado se forem mantidos os treinamentos para a formação inicial e periódica relacionados ao transporte de artigos perigosos para todos os envolvidos. Anac (2009).

O transporte de artigos perigosos é regulamentado por diversas legislações, sendo elas brasileiras e internacionais, conforme citado a seguir:

- Anexo 18 da Convenção de Chicago (1944) para a aviação civil da ICAOTransportes seguro de artigos perigosos via aérea;

- DOC 9284-AN/905 da ICAO Instruções técnicas para o transporte seguro de mercadorias perigosos pelo modal aéreo;

- Manual IATA - regulamentação aérea para o transporte de artigos perigosos (DGR);

- Regulamentos Brasileiros da Aviação Civil (RBAC) no 175 e suas Instruções
Suplementares da ANAC - Transporte de artigos perigosos;

- $\quad$ Código Brasileiro de Aeronáutica - Lei 7565 dezembro/86;

- $\quad$ Código Penal Brasileiro.

\section{PESQUISA DE CAMPO \\ 4.1 ANÁLISE DOS RESULTADOS}

A pesquisa da campo foi aplicada em abril de 2018 com profissionais de empresas expedidoras que consolidam a carga no transporte aéreo e o agente de cargas que trabalha no embarque de produtos perigosos de um aeroporto brasileiro.

A pesquisa foi iniciada com a seguinte pergunta ao agente líder da cia aérea:

Qual o principal erro encontrado para a recusa de embarque de artigos perigosos? Após uma consulta em seus arquivos de controle, ele destacou como principal motivo para as recusas desses embarques, os erros de etiquetagem e marcações nos volumes. 0 mesmo ainda cita que existem também erros na parte documental, todavia são menos frequentes.

Também foi perguntado qual era a empresa que apresentava o maior índice de embarques rejeitados devido a esses erros. A princípio o colaborador ficou um pouco relutante em divulgar esse dado, mas após darmos garantia que nenhum nome seria revelado, o mesmo nos apontou qual a empresa consolidadora apresentava o maior índice de recusas.

Entramos em contato com três colaboradores da referida empresa consolidadora e fizemos as seguintes perguntas: Você tem curso de artigos perigosos? Qual o principal motivo para a ocorrência de erros nesses embarques?

Dos três colaboradores entrevistados, o primeiro não tinha nenhum curso de cargas perigosas, o segundo tinha o curso mas estava vencido, e o terceiro tinha o curso em dia, mas o mesmo ressaltou que não tem muita vivencia com esse tipo de embarque e ainda encontra um pouco de dúvidas em algumas questões.

Em resposta a segunda pergunta, em geral os três colaboradores tiveram a mesma linha de resposta: Falta de conhecimento e vivencia mais constante com esse tipo de embarque e 
o fato de não ter manual IATA escrito na língua portuguesa. Os colaboradores disseram que seria de grande utilidade se existisse um material de apoio escrito em português.

Uma análise no processo de embarque revela que a crescente frequência das ocorrências desse tipo no último semestre pode estar trazendo perdas acumulativas significativas para a empresa, chamando a atenção para o impacto financeiro e para a imagem da organização.

As companhias aéreas que trabalham com produtos perigosos consultadas em um aeroporto brasileiro constataram um número crescente de embarques rejeitados de produtos perigosos, também conhecidas popularmente na aviação como Dangerous Goods (DG), devido a simples erros de posicionamento de etiquetas e marcações nos volumes.

Embora pareça um pequeno problema, ele traz impactos significativos para as empresas responsáveis por esse embarque, porque gera:

- aumento no tempo do lead time da entrega do produto;

- atraso no processo de entrega do produto;

- aumento dos custos logísticos com custos extras para os expedidores, com os referidos embarques, pois, cada vez que o operador aéreo vai checar um volume de artigo perigoso é cobrado a quantia de \$20 (vinte dólares), por grande maioria das companhias aéreas.

É preciso considerar, que em meio a tantas exigências, muitos profissionais que manuseiam artigos perigosos desconhecem este regulamento, acarretando então, na falta de cuidados a serem tomados com estes.

Eles estão sendo barrados pelas companhias aéreas devido à erros em marcações e etiquetagens nos produtos perigosos, cometido por seus colaboradores, impedindo o embarque desses volumes, uma vez que a regulamentação prega que todas as etiquetas e marcações devem estar em conformidade com a documentação entregue a cia aérea.

Mesmo quando as devidas alterações são realizadas no mesmo dia, esses embarques acabam ficando parados e perdendo suas reservas de espaços nas aeronaves, pois, quando o embarque é rejeitado pela companhia aérea existe um prazo préestabelecido de 24 horas para ser realizado o Re-check pela empresa. Além do fator tempo, esses problemas com etiquetagem e marcações acabam causando o aumento de custos para os embarques, pois, algumas cias aéreas cobram uma taxa de 20 dólares por cada vez que vão verificar se os volumes de artigos perigosos estão devidamente etiquetados.

Devido à abrangência do tema, pode -se constatar que podem existir algumas dificuldades quanto a interpretação dos regulamentos. Todavia com a utilização do manual IATA, pode-se notar que o mesmo buscou oferecer ao mercado uma publicação de fácil compreensão e manuseio, estabelecendo procedimentos tanto para o embarcador quanto para o transportador, visando dessa forma, garantir a segurança da aviação civil, em contrapartida temos o problema desses manuais somente serem impressos nos idiomas inglês, francês, alemão, russo, espanhol, chinês e japonês, o que acaba dificultando para alguns, por não ser nosso idioma nativo.

Vale ressaltar que parte do expedidores consultados não tinham nenhum curso para o devido manuseio e etiquetagem dos artigos perigosos, ou seus cursos estavam vencidos. O que pode explicar a tendência de erros nas respectivas marcações e etiquetagem dos volumes.

\subsection{RECOMENDAÇÕES PARA REDUZIR E EVITAR EMBARQUE REJEITADO}

É preciso investir na reciclagem dos conhecimentos sobre manuseio, movimentação e embalagem de produtos perigosos. O setor de recursos humanos da empresa expedidora poderia estabelecer uma programação periódica dos treinamentos para atualização profissional, incentivando os profissionais a manterem o nível de serviço logístico com o devido cumprimentos da legislação e das normas técnicas pertinentes.

O treinamento para reciclagem ou atualização deve evidenciar o processo de embarque e as informações específicas sobrea embalagem, etiquetagem, rotulagem e marcação dos produtos perigosos, seguindo diretrizes da IATA.

O não cumprimento dessas diretrizes pode estar associado à diferentes causas: 
- $\quad$ algum trabalhador não está seguindo as informações previstas nos procedimentos padrão de embarque;

- a empresa não fez investimento para a reciclagem e atualização dos treinamentos dos trabalhadores.

- o treinamento realizado com os trabalhadores não teve o efetivo resultado na qualidade do serviço prestado oferecido pela empresa.

Recomenda - se a criação de um check-list, em português, para os colaboradores utilizarem no momento que estão realizando as etiquetagens e marcações dos artigos perigosos, servindo como base de apoio, dessa forma facilitaria para aqueles que tem dificuldades com o idioma e entendimento do manual considerando os itens a seguir: embalagem, etiquetagem e marcação.

\section{A - Embalagem}

No transporte de cargas perigosas, é de máxima importância que seja realizada a embalagem de acordo as regulamentações, para que a movimentação do produto de um ponto ao outro aconteça com segurança. É fundamental considerar os potenciais efeitos adversos de temperatura, pressão e as variações de umidade, assim como o risco de danos, devido as vibrações e ao manuseio inadequado ao transportar por via aérea.

O transportador é responsável por todos os aspectos da embalagem das mercadorias perigosas, em conformidade com o Regulamento IATA para atender à diretrizes da ANAC (2018).

Ao preparar cada embalagem de mercadorias perigosas, o remetente deve cumprir um conjunto de requisitos adequados para o tipo de embalagem a ser utilizado, utilizar apenas as embalagens autorizadas pela instrução de embalagem aplicável especificado no manual mercadorias perigosas, restringir a quantidade total por embalagem para os limites especificados na Lista de Mercadorias Perigosas (conforme o caso) ou até o limite de design para o pacote que for mais restritivo.

Além disso, nas embalagens combinadas, o limite de quantidade por embalagem interior não deve exceder os limites especificados na instrução de embalagem aplicável, montar e proteger todos os componentes da embalagem exatamente da forma pretendida, assegurar que as superfícies externas da embalagem montada estão limpos de contaminação provenientes do processo de enchimento em si, ou contaminação a partir do ambiente circundante da área de enchimento / montagem, e garantir que as suas responsabilidades para com as embalagens são totalmente cumpridas quando o pacote é apresentado ao operador para o embarque.

\section{B - Etiquetagem e marcações}

A etiquetagem mostra a natureza de risco da carga, definindo o tipo de material que se encontra no volume, com as informações sobre armazenagem e manuseio de maneira segura. Cabe as envolvidos no despacho de produtos perigosos por via aérea, verificar se todas etiquetas foram aplicadas de forma corretas antes de aceitar a carga para embarque pois a correta aplicação de marcas e etiquetas em embalagens contendo artigos perigosos é elemento de segurança essencial, no processo de transporte.

Vale ressaltar que, o embarcador é responsável pela correta marcação e etiquetagem dos volumes contendo artigos perigosos, sendo dele a responsabilidade de garantir que a embalagem, ao ser entregue ao operador aéreo, não traga nenhuma marca ou etiqueta que não esteja devidamente relacionada ao embarque.

De acordo com a IATA (2018), existem dois tipos de etiquetas, são elas:

Etiquetas de Risco - Que são necessários na maioria dos produtos perigosos em todas as classes.

Etiquetas de Manuseio - Que são necessários quer isoladamente ou em conjunto com as etiquetas risco, para alguns produtos perigosos.

Todas as etiquetas de perigo e as etiquetas de manuseio utilizados em embalagens de produtos perigosos, e sobre embalagens contendo produtos perigosos devem estar de acordo, em forma, cor, formato, símbolo e texto, para os projetos de espécies reproduzidas pelo manual IATA, conforme indicado no quadro 1. 
Quadro 1 - Aspectos da etiquetagem nos produtos perigosos

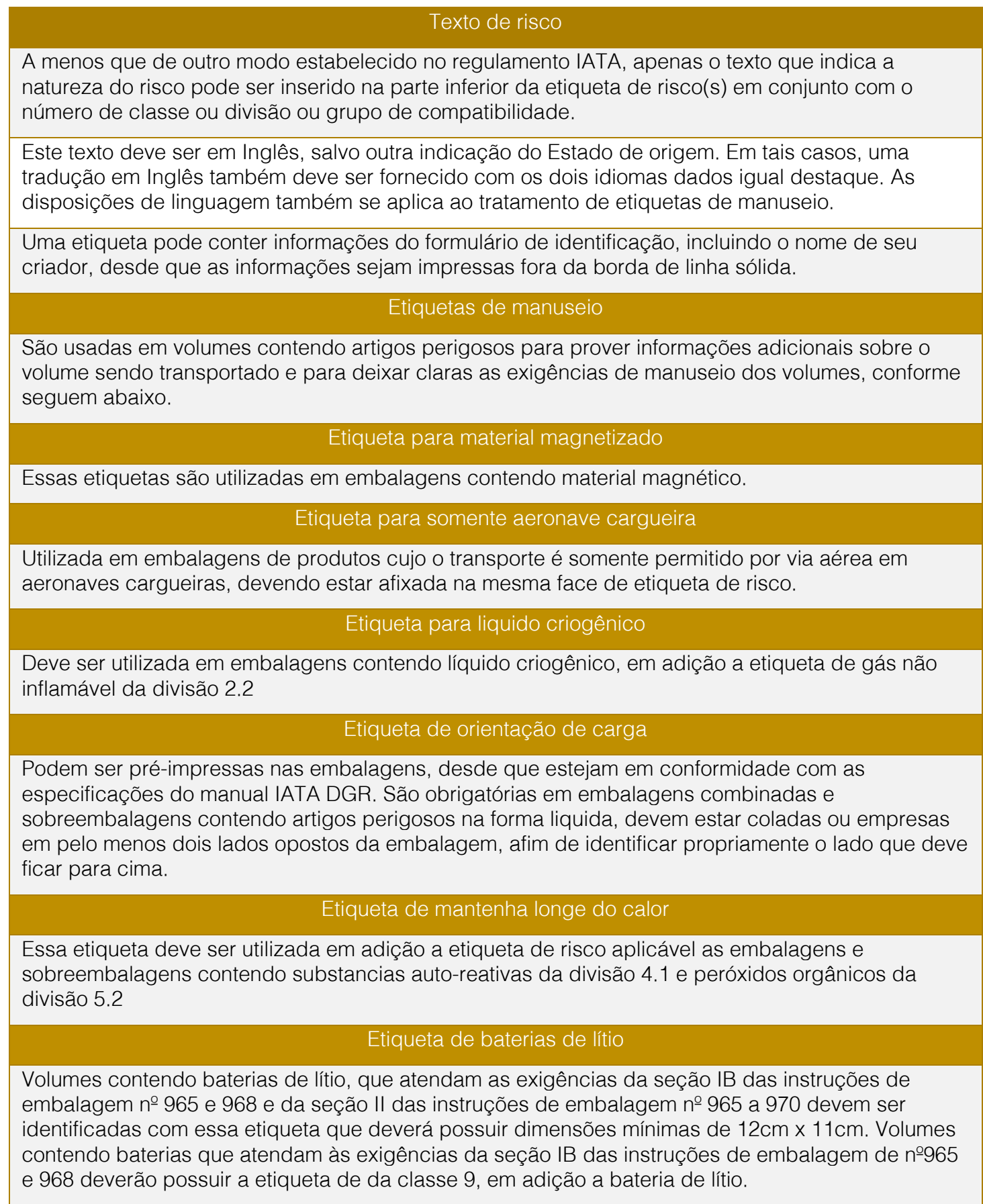

Fonte: adaptado do IATA (2018)

C - Marcações

De acordo com a regulamentação IATA (2018), existem dois tipos de marcas, são elas: as de certificação de embalagem e as de uso.

As marcações de certificação de embalagens apresenta informações sobre o tipo de embalagem, material de fabricação, marcação com o símbolo UN, que certifica que a embalagem passou pelos devidos testes, grupo de embalagens pertencente, ano de fabricação, pais onde a embalagem foi homologada, código ou nome do fabricante da embalagem e o órgão homologador da embalagem. Já as marcas de uso indica literalmente que uso foi dado aquela embalagem em particular. O Quadro 2 resume algumas recomendações importantes. 


\section{Quadro 2 - Recomendações para marcações nos produtos perigosos}

Marcas de uso para artigos perigosos deve possuir uma altura mínima de 12mm, com exceção para embalagens com capacidade de até $30 \mathrm{~kg}$ ou $30 \mathrm{~L}$, que podem ser feitas com $6 \mathrm{~mm}$ de altura.

Essas marcações devem ser duráveis, com capacidade de aguentar as exposições as intempéries sem deteriorar-se, estando claramente legíveis e visíveis e sempre com um fundo contrastante, facilitando assim, a devida visualização.

Deve ser informado na embalagem o número UN, o nome próprio para embarque e quando requerido pelo regulamento o nome técnico, nome e endereços completos do embarcador e do consignatário.

Quando o embarque tiver mais de um volume, sendo que, esses com pesos diferentes, a quantidade liquida de cada volume deve ser indicada e estar adjacente às informações de UN/nome próprio para embarque. Vale lembrar que caso caso o limite esteja informado no manual acompanhado de uma letra $G$, as embalagens devem indicar o peso bruto acompanhado de uma letra G. EX: $150 \mathrm{~kg} \mathrm{G}$

Quando o embarque tratar-se de gelo seco UN 1845, a quantidade liquida em cada embalagem deve ser informada, mesmo que seja apenas um volume.

Nos gases refrigerados liquefeitos, a posição correta da embalagem deve ser informada com as etiquetas de setas indicativas de direção, com as palavras Keep Upright (mantenha em pé), dispostas em intervalos de $120^{\circ}$ ao redor da embalagem cilíndrica, ou, em caso de caixa, em cada lado da embalagem. Também é obrigatório ter uma marcação clara com os dizeres Do Not Drop - Handle with care (Não deixe cair, manuseie com cuidado). São necessários instruções a serem seguidas em caso de emergência.

Para as substâncias infecciosas é necessário informar o nome da pessoa responsável pelo embarque e seu telefone de contato na embalagem.

Produtos biológicos da categoria B UN 3373(Figura 2) devem possuir marcação em formato de diamante com o número UN da substancia. Não existe a necessidade de informar o peso liquido na volume, todavia, se essa for refrigerada por gelo seco, deve-se informar a quantidade de gelo.

Equipamentos autônomos de respiração contendo geradores químicos de oxigênio, sendo transportados de acordo com a provisão especial A144 deverão trazer junto ao nome próprio para transporte a inscrição Air Crew Protective Breathing Equipment (Smoke Hood).

Nos embarques contendo explosivos é necessário mencionar a quantidade liquida de explosivos e o peso bruto dos volumes. O nome próprio para transporte poderá ainda ser complementado por um texto adicional indicando o nome comercial ou militar do explosivo.

Embalagens contendo substancias perigosas para o meio ambiente das UN's 3077 e 3082 devem apresentar a marcação especifica para poluentes Figura 3, em adição a etiqueta de classe 9 obedecendo as dimensões mínimas de $100 \mathrm{~mm} \times 100 \mathrm{~mm}$.

Embalagens para o transporte de cargas sob provisões de quantidade limitada devem possuir marca especifica para esse tipo de embalagem Figura 4 em dimensões mínimas de $100 \mathrm{~mm} \times 100 \mathrm{~mm}$

Fonte: adaptado do IATA, DGM, Arican, Hazshop (2018)

Figura 2 - Etiqueta de UN 3373

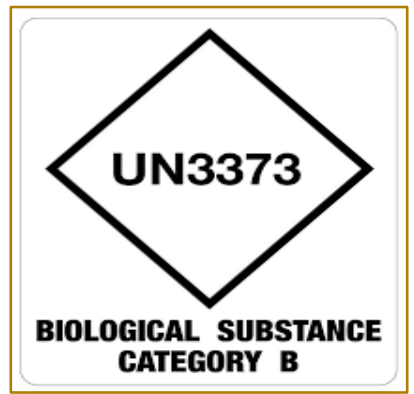

Fonte: DGM (2018) 
Figura 3 - Etiqueta de poluente para UN's 3077 e 3082

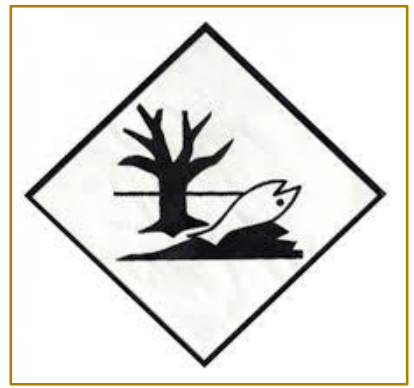

Fonte: Arican (2018)

Figura 4 - Etiqueta de Quantidade Limitada

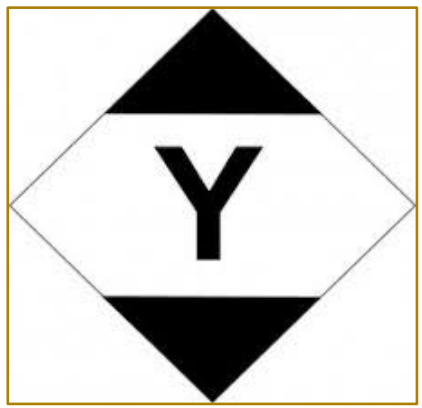

Fonte: Hazshop (2018)

\section{CONSIDERAÇÕES FINAIS}

Os resultados deste estudo indicam que apesar da complexibilidade do tema, acredita-se que os procedimentos incorretos quanto às etiquetagens e marcações em produtos perigosos devem-se principalmente à falta de treinamento dos envolvidos na operação. É importante salientar que é obrigação do expedidor de carga aérea ou de qualquer pessoa que atue como intermediário entre o expedidor e o operador de transporte aéreo, assegurar que todos os requisitos aplicáveis ao transporte aéreo, sejam cumpridos.

A ANAC deixa claro que o treinamento é um elemento essencial para a garantia da segurança do transporte de artigos perigosos por via aérea, sendo necessário que todo o quadro de pessoal envolvido na preparação e no transporte de artigos perigosos, bem como todos os envolvidos na cadeia do transporte aéreo em geral. Esta pesquisa amplia nosso conhecimento sobre etiquetas e marcações para artigos perigosos, porém, uma limitação desse estudo é que a regulamentação IATA é atualizada anualmente, podendo haver alterações e/ou exclusões, de determinadas regras abordadas.

Outro motivo que pode ter contribuído para o embarque rejeitado é a falta de um sistema de controle ou conferência após a consolidação da carga. O uso de um check list como procedimento obrigatório pode minimizar as ocorrências de embalagens ou etiquetagens incorretas ou não conformes no embarque.

Sendo assim, fica muito evidente que é de grande importância que os envolvidos nesse tipo de transporte tenham cursos periódicos pelo menos a cada dois anos, conforme recomenta a legislação e um maior controle de processo.

As considerações tratadas neste estudo estão limitadas ao contexto da pesquisa de campo e por isso não podem ser generalizadas.

Sugere-se estudos semelhantes em portos, terminais rodoviários e ferroviários que também lidam com embarque de produtos perigosos. 


\section{REFERENCIAS}

[1]. ANAC - Agência Nacional de Aviação Civil. Regulamentação de artigos perigosos. Disponível em $<$ http://www.anac.gov.br/assuntos/passageiros/arti goperigoso-1/regulamentacao-de-artigosperigosos> Acesso em 28, abr. 2018.

[2]. ANDRADE NETO, José Nicodemos de; OLIVEIRA NETTO, Sérgio Eduardo de. Transporte de produtos perigosos: diretrizes de regulação para embalagem. 2005. 71 f. Monografia (Especialização em Gestão da Aviação Civil)Universidade de Brasília, Brasília, 2005.

[3]. ARICAN. Rótulo de risco os 30x30 perigo ao meio ambiente. Disponível em https://www.arican.com.br/rotulo-de-risco-ps30x30-perigo-ao-meio-ambiente.html Acesso em 28, abr. 2018

[4]. ASHFORD, Norman J. et al. Operações aeroportuárias: as melhores práticas. 3a. ed. Porto Alegre: Bookman, 2015.

[5]. BALLOU, Ronald H. Gerenciamento da Cadeia de Suprimentos / Logística Empresarial. 5으 ed. Porto Alegre: Bookman, 2006.

[6]. NOVAES, Antônio Galvão. Logística e gerenciamento de distribuição. São Paulo: Campos, 2001.
[7]. BELLAN, Natália; PINTO, Terezinha de Jesus (coords.). Diretrizes do processo de regulamentação sanitária dos medicamentos no Brasil. São Paulo: Manole, 2016.

[8]. CAIXETA FILHO, J.V.; MARTINS, R.S. Gestão logística do transporte de cargas. São Paulo: Atlas, 2001.

[9]. DIAS, M.A.P. Administração de materiais: princípios, conceitos e gestão. 5. ed. 4. reimpr. São Paulo: Atlas, 2009.

[10]. DGM. Etiqueta "substancia biológica" CATB. Disponível em https://dgmspain.com/etiqueta-sustancia-biologica-categoria-b Acesso em 20, abr. 2018.

[11]. DREAMSTIME. Página principal. Disponível em https://pt.dreamstime.com/fotografiade-stock-royalty-free-pictograma-perigosos-sinaisdos-bens-image24427607 Acesso em 28, abr. 2018.

[12]. HAZSHOP. Quantidade limitada (IATA). Disponível em https://www.hazshop.com/br/100mm-hazardlabels/25-limited-quantities-iata.html Acesso em 28, abr. 2018.

[13]. IATA - International Air Transport Association,. Dangerous Goods Regulation 59a‥ ed. IATA,

2018. 


\section{Capítulo 9}

\section{ANÁLISE SOBRE AS CONDICIONANTES DA EXPORTACÃO DE CARNE DE FRANGO HALAL BRASILEIRA PARA PAISES DO ORIENTE MEDIO E ISLÂMICOS}

\section{Amanda Domingues \\ Ralph Felipe Alves Benites \\ Paulo Cesar Giuliani}

Resumo: O Brasil é líder e referência global na exportação da carne de frango Halal para países do Oriente Médio e muçulmanos. No entanto, existem condições que devem ser atendidas por parte das empresas produtoras do país, para garantir a atuação no mercado religioso, em específico, o islâmico. As condições são pautadas pela Lei Islâmica e os países importadores exigem uma certificação denominada Halal (lícita), que abrange um conceito importante presente no modo de vida dos muçulmanos e consequentemente no consumo. A certificação Halal assegura que toda a cadeia produtiva respeita e segue os parâmetros estabelecidos além de permitir que as empresas produtoras pratiquem o conceito de forma correta nos processos de embalagem, armazenagem e transporte da carne de frango Halal. Por intermédio das medidas de rastreabilidade, supervisão e controle é possível garantir que todo o processo antes e após o abate é lícito, desde a criação das aves, suprimentos necessários até o embarque para os países de destino final. Este artigo possui como objetivo analisar como um órgão de expedição de certificados Hala/no Brasil realiza o gerenciamento dos processos da cadeia de produção da carne de frango Halal e acompanha o cumprimento das especificidades com o devido rigor necessário e adequado para a produção Halal.

Palavras-chave: Mercado Internacional. Certificação. Cadeia Produtiva. 


\section{INTRODUÇÃO}

O Brasil é um dos maiores líderes no que tange a exportação de carne de frango Halal, devido a sua grande expertise de produção e abertura nas negociações com países muçulmanos (TEDESCO, 2016). Entretanto, os países importadores exigem que os alimentos sejam certificados por instituições e/ou organizações diretamente ligadas com a religião Islâmica e este tipo de certificação é denominada como Halal (FALCO ET AL, 2015). A certificação Halal abrange o modo como as aves devem ser abatidas e demais especificidades (CDIAL HALAL, 2017). Porém Halal não abarca somente de acordo com Tedesco (2016) a questão do abate, na verdade é um conceito amplo que serve para diversos domínios na vida de um muçulmano.

A palavra Halal tem sua origem na língua árabe e significa lícito ou liberado e quando uma empresa certifica seu processo e produto como Halal, isto significa que toda a sua cadeia produtiva deverá atender diversas condições pautadas pela Jurisprudência Islâmica (CDIAL HALAL, 2017). De acordo com Ribeiro (2014) o comércio de alimentos Halal vem se tornando de grande relevância no mercado global, logo a necessidade de oferecer a qualidade e segurança dos produtos que são exportados é de extrema importância para tornar o incentivo à produção ainda maior e beneficiar as exportações do país.

Consequentemente de acordo com ISLAMIC HALAL (2017) o conceito de rastreabilidade estará presente em toda cadeia produtiva Halal.

O objetivo deste artigo é analisar por intermédio de consulta com uma organização certificadora Halal como os processos de produção da carne de frango, embalagem, armazenamento e transporte são realizados. Os objetivos específicos concernem em abordar e explorar de que forma as exigências de exportação para países muçulmanos estabelecidas juntas a certificação Halal refletem na logística.

Com o intuito de atingir os objetivos propostos foram realizadas uma pesquisa bibliográfica e uma consulta com a organização certificadora visando embasar o conteúdo apresentado. O artigo possui caráter exploratório e qualitativo para assim propiciar o entendimento acerca dos processos logísticos ligados com a exportação da carne de frango Halal para o mercado islâmico.
A pesquisa exploratória possui como objetivo promover maior proximidade com a problemática, por meio do enfoque em transformá-la mais límpida durante o desenvolvimento das hipóteses (GIL, 2007). Este tipo de pesquisa de acordo com Gil (2007) costuma abranger o levantamento de bibliografia, entrevistas ou consultas com indivíduos experientes com relação ao problema de pesquisa e análise de exemplos para o entendimento. A abordagem de natureza qualitativa segundo Malhotra (2005) visa proporcionar melhor acesso e entendimento sobre a problemática.

Assim, há o levantamento de questões que norteiam os três importantes fatores, a função da certificação, as condicionantes do mercado Halal e a disposição do Brasil em atender o mercado muçulmano considerando suas exigências. Inicia-se o artigo com a explicação sobre o conceito Halal, a finalidade da certificação e como se caracteriza o abate Halal. Em seguida ocorrem a apresentação da organização certificadora, dos aspectos que abarcam a logística inicialmente e a análise sobre a diferenciação no que concerne aos processos logísticos existentes neste contexto de exportação. E também como os processos são realizados e controlados pelas certificadoras para assegurar a confiabilidade por parte dos países importadores.

\section{REFERENCIAL TEÓRICO}

\subsection{CONCEITO HALAL}

Halal do árabe, significa lícito, permitido ou autorizado e no que tange ao consumo humano trata-se daquilo que é liberado para o muçulmano (CDIAL HALAL, 2017). Em outro contexto o que é lícito pode ser entendido como padrão ético e moral de ações tidas como corretas socialmente, nas finanças, na alimentação e entre outros aspectos (FAMBRAS HALAL, 2017). De acordo com FAMBRAS HALAL (2017) ao contrário do que se acredita, o conceito não se restringe apenas à degola de um animal e ao ritual baseado nas tradições islâmicas, Halal é um conjunto de princípios e valores que visa beneficiar a humanidade.

Os padrões Halal abrangem uma ampla cadeia produtiva e comercial fundamentada por métodos de garantias, confiança, qualidade e ritualismo religioso para atender às necessidades e exigências dos 
consumidores muçulmanos, especificamente (TEDESCO, 2016). Conforme CDIAL HALAL (2017) as empresas praticantes do conceito Halal utilizam matérias-primas, insumos e auxiliares de processo 100\% Halal (lícito), fabricam alimentos e produtos que não afetam a saúde humana. Onde há transparência no processo produtivo, há uma conduta comercial correta e com justiça, além de realizarem boas práticas em seus processos fabris, agem com respeito ao meio ambiente e a sociedade como um todo.

A FAMBRAS HALAL (2017) enfatiza ainda a não utilização da mão de obra escrava e infantil e que tudo que é determinado pela legislação vigente é respeitado.

De acordo com CDIAL HALAL (2017) os alimentos Halal são aqueles cujo consumo é permitido para os muçulmanos e tendo como base as Leis Islâmicas, ou seja, todo tipo de alimento que não contenha ingredientes proibidos ou de animais que tenham sido abatidos respeitando as normas contidas no Alcorão Sagrado e ditadas pela Jurisprudência Islâmica e alimentos naturais que não tenham sua natureza modificada por algum insumo que é considerado Haram (ilícito).

Destaca CDIAL HALAL (2017) que os alimentos Haram (ilícitos) são o álcool e seus derivados, sangue animal e seus derivados, assim como a carne suína e seus derivados e são proibidos ao consumo do muçulmano.

\subsection{A CERTIFICAÇÃO HALAL}

A certificação Halal é um processo no qual uma agência controlada pelo governo e/ou uma organização islâmica reconhecida, certifica as indústrias para que pratiquem os procedimentos permitidos, produzir, armazenar e comercializar produtos destinados aos muçulmanos (FAMBRAS HALAL, 2017). O certificado Halal e o selo de garantia Halal são meios para que o consumidor muçulmano consiga consumir produtos Halal com certa confiabilidade (CIBAL HALAL, 2009). Conforme FAMBRAS HALAL (2017) o certificado Halal se trata de um documento emitido por uma organização certificadora, reconhecida por países muçulmanos, para garantir que a empresa, processo e produtos sigam os requisitos que são determinados. Para CIBAL HALAL (2009) o certificado é a garantia que o produto é lícito e que a produtora segue os procedimentos e requisitos conforme a lei Islâmica. Além disso ainda de acordo com CIBAL HALAL (2009) as empresas devem analisar o nível de reconhecimento mundial da instituição certificadora antes de adquirir o certificado, buscando os órgãos responsáveis de países islâmicos para saber quais certificadoras são reconhecidas.

Segundo Tedesco (2016), a dinâmica da certificação Halal possui relação com entidades de caráter internacional, principalmente de países muçulmanos, particularmente, situadas na Arábia Saudita, Egito e Iraque e também europeias.

Segundo Ribeiro (2016), para a obter o certificado, a empresa deve passar por um criterioso e rigoroso processo de investigação e fiscalização realizado durante 0 processamento do produto.

De acordo com Tedesco (2016) cada país impõe suas exigências e requisitos para obtenção da certificação com base naquilo que consideram como fundamentais, ou seja, existem regramentos que podem ser diferenciados. Entretanto, tudo sempre de acordo com a Jurisprudência Islâmica.

A certificação Halal conforme CIBAL HALAL (2009) agrega positivamente para a imagem dos produtos e das empresas; os consumidores muçulmanos associam confiabilidade com o produto quando ele é certificado e acompanhado pelo selo da organização certificadora de Halal. No Brasil de acordo com Tedesco (2016) existem grandes certificadoras e são todas envolvidas diretamente com o Islam e possuem forte nível de reconhecimento.

É perceptível o vínculo existente entre economia e mercados globalizados com a tangência religiosa e como é posto em escala ainda maior pelos meios empresariais (TEDESCO, 2016). Para Tedesco (2016) isso é perpetuado desde indústrias, comércios, organizações certificadoras, importadores e entre outros fatores dessa esfera.

\subsection{O ABATE HALAL DE AVES (FRANGOS)}

Antes de ocorrer o abate existem algumas exigências que não se limitam apenas ao setor de sangria, que vão desde a criação do pintinho (como os ovos são chocados e armazenados) até a ração utilizada para engordar o frango que possibilita as aves de se desenvolverem sem a utilização de 
anabolizantes (TEDESCO, 2016). O abate Halal em um frigorífico segundo CDIAL HALAL (2017), deve ser executado separadamente do não Halal e consiste em visar o bem-estar do animal e prezar a boa qualidade do alimento. Trata-se de acordo com Tedesco (2016) de uma atividade que requer muitos cuidados com a segurança, confiança e garantias de que as exigências serão devidamente cumpridas.

A técnica Halal de abate, determina que os frangos sejam abatidos com seus peitos direcionados para Meca (local sagrado para os muçulmanos e se encontra na Arábia Saudita) e com um corte em movimento de meia-lua no pescoço realizado por uma faca afiada com o animal já desperto (MESSAGI, 2014). Devem ser abatidos somente animais saudáveis, aprovados pelas autoridades e que estejam em ótimas condições físicas, utilizando equipamentos e utensílios exclusivos (CDIAL HALAL, 2017). O abate segundo CDIAL HALAL (2017) deve ser realizado por um muçulmano mentalmente sadio, que conheça os fundamentos do abate no Islam e a frase "Em nome de Allah, o mais bondoso, o mais Misericordioso" deve ser dita antes como forma de agradecimento e remissão pelo ato .

O sangue não pode ser consumido, logo, o processo de degola necessita permitir que ele seja totalmente eliminado (TEDESCO, 2017). Assim, a faca utilizada deve estar bem afiada para que 0 ato da sangria seja único $e$ minimize o sofrimento do animal, o corte visa atingir traqueia, esôfago, artérias e veia jugular fazendo com que o sangue seja escoado (CDIAL HALAL, 2017). Conforme FAMBRAS HALAL (2017) o inspetor muçulmano possui a responsabilidade de verificar se os animais são abatidos corretamente e de acordo com a Sharia (lei Islâmica).

Recentemente segundo a Câmara de Comércio Árabe-Brasileira (2018) o Brasil entrou em discussão com a Arábia Saudita sobre o padrão de abate Halal. Ainda de acordo com a Câmara de Comércio ÁrabeBrasileira (2018) o país árabe recusa o atordoamento de frangos por meio da prática de choques elétricos antes da degola, mas os brasileiros afirmam que o método atende às exigências religiosas e sanitárias.

\section{ANÁLISE SOBRE AS CONDICIONANTES E PAPEL DA CERTIFICADORA NOS PROCESSOS LOGÍSTICOS EXISTENTES}

\subsection{A CERTIFICADORA HALAL}

A partir de uma consulta com um colaborador da certificadora houve a oportunidade de compreender como ela surgiu e quais foram as suas motivações para desempenhar a atividade relacionada com a certificação Halal no Brasil.

No final da década de 80 , foi fundada uma organização que promove diversos congressos relacionados à comunidade islâmica internacional. Logo após, o fundador da organização recebeu uma solicitação para que fossem prestados serviços relacionados ao abate Halal no Brasil, assim foi criado um grupo que desenvolveu um sistema de abate e fiscalização da produção para os abatedouros.

Os governos de alguns países do Oriente Médio determinaram que a organização fosse a prestadora de serviços exclusiva de certificação Halal para alimentos, determinando parâmetros para os procedimentos das atividades.

A empresa está no segmento desde 1990 aproximadamente, é referência no mundo em certificação Halal e conta com diversas parcerias empresariais de caráter mundial e está localizada na cidade de São Bernardo do Campo no estado de São Paulo.

A organização conta com cerca de 500 colaboradores e certificações em 95 plantas de fábricas no Brasil. É uma das maiores fornecedoras de mão de obra especializada Halal, ou seja, muçulmana.

As atividades certificadas incluem desde o abate de aves, bovinos e também produtos industrializados.

A partir da consulta com o colaborador da organização certificadora foi possível entender melhor $\mathrm{e}$ analisar os aspectos $\mathrm{e}$ fatores que abarcam a relação comercial do Brasil com países do Oriente Médio e muçulmanos. E como funciona a exportação Halal, uma vez que são estabelecidas especificidades relacionadas ao contexto religioso no qual há a necessidade de atender os requisitos pautados pela Lei Islâmica (Sharia) presente no Alcorão (livro sagrado). 
O grande enfoque da consulta foi descobrir como os requisitos existentes em uma produção Halal, em específico, na de carne de frango destinada à exportação refletem em alguns processos da logística e como ela vai funcionar neste contexto.

\subsection{O MERCADO HALAL DE EXPORTAÇÃO}

Durante a consulta ficou claro que o mercado Halal está em constante crescimento e possui um enorme potencial. Trata-se de um mercado estimado em mais de $\cup \$ \$ 2,3$ trilhões de acordo com dados da organização certificadora, além disso os muçulmanos compõem grande parte da população mundial e moldam um dos grandes mercados de alimentos e bens para consumo em todo o mundo.

O segmento Hala/ não é limitado apenas aos produtos alimentícios e abrange outros domínios, como produtos farmacêuticos, cuidados pessoais, cosméticos, vestuário, serviços relacionados com finanças e turismo, logística e entre outros. Tornando a gama de consumidores maior, por não se restringir apenas aos muçulmanos, por possuir um selo de garantia Halal que é considerado como um símbolo de qualidade, saúde e respeito ao meio ambiente como um todo.

O Brasil é uma referência global no que tange ao fornecimento e como maior exportador de produtos Halal do mundo. Está na liderança de produção e exportação de carne Halal (aves e bovinos), o país exporta para diversos países islâmicos, porém objetiva ampliar ainda mais seu espaço no mercado Halal. O país começou no segmento com o intuito de atender a pequena demanda interna, porém houve a percepção de que havia um grande potencial do ramo no comércio exterior e hoje a expectativa é de que até 2020 cresça em até $60 \%$ segundo o colaborador.

Quanto ao tamanho dos frangos exportados nos foi informado que este é variável, cada importador possui uma demanda de mercado. Alguns países dão prioridade aos frangos inteiros, outros somente peitos e sobrecoxas, ou seja, os tamanhos e os cortes são diferentes e de acordo com cada demanda e preferência.

Arábia Saudita, Emirados Árabes, Egito e entre outros são alguns dos países que mais importam a carne de frango Halal brasileira que é certificada pela organização.
Mas de um modo geral de acordo com o colaborador Indonésia, Turquia, Paquistão, Malásia, Índia, Marrocos e outros países também integram o conjunto dos grandes mercados Hala/no mundo atualmente.

\subsection{CONGRESSOS SOBRE O MERCADO HALAL}

Destacou-se durante a consulta o fato de que a certificadora promove junto com outras expedidoras congressos sobre exportação, expectativas do mercado como um todo, medidas de expansão, relações comerciais entre o Brasil e os importadores e entre outros aspectos.

São tratados os fatores que são considerados de extrema importância como a padronização dos abates nos frigoríficos, a origem dos suprimentos utilizados, os métodos de destaque durante a embalagem (selo, etiquetas e outros) e armazenagem (câmaras de resfriamento exclusivas) dos produtos Halal e também o rastreamento das condições em que são transportados os produtos.

Além disso são debatidos os fatores pertinentes à confiabilidade e percepção que estão relacionados principalmente com a mão-de-obra que deve ser consciente sobre as normas Halal, a flexibilidade dos frigoríficos em atender os requisitos exigidos pelos importadores, o respeito ao ritual islâmico que permeia o processo produtivo diretamente e entre outros. O maior objetivo é manter o Brasil na liderança das exportações de produtos Halal e estimular as empresas a praticarem o conceito Halal, por meio da rentabilidade existente no mercado.

\subsection{CONSIDERAÇÕES INICIAIS SOBRE A LOGÍSTICA HALAL PARA EXPORTAÇÃO DA CARNE DE FRANGO}

Segundo o colaborador da certificadora analisada, os processos de produção, embalagem, armazenagem, certificação e embarque da carne Halal são executados separadamente da produção não Halal. Logo, as linhas Halal e as câmaras frias dispostas para a armazenagem da carne são exclusivas, há a presença de etiquetas e selos nas embalagens dos produtos para destacá-los e diferenciá-los para que não ocorram misturas e o transporte até os países 
de destino deve ser realizado em contêineres separados.

E todos esses procedimentos servem para evitar contaminação e mistura com outros produtos que não possuem natureza Halal. É de extrema importância ressaltar que as matérias-primas e suprimentos são monitorados, assim como a logística e os sistemas de transporte para que a empresa certificadora possa garantir a segurança e a confiabilidade dos produtos denominados Halal.

Com o propósito de executar esses processos e operações logísticas a empresa certificadora Halal desenvolve e utiliza procedimentos que serão abordados a seguir.

\subsection{PROCEDIMENTO, EMBALAGEM, ARMAZENAGEM E TRANSPORTE}

De acordo com o colaborador as exigências da prática do conceito Halal se iniciam na criação das aves. O solo no qual vão crescer deve ser analisado quimicamente, as rações devem ser balanceadas de modo que não seja necessária a utilização de anabolizantes e os tipos de vacina são diferenciados. Os frangos não podem ter contato com outros animais que não são destinados ao abate Halal e devem viver livremente em meio a natureza, não sendo privados de seu bem estar.

Nos frigoríficos ocorre uma vistoria para constatar se a estrutura da planta fabril corresponde aos procedimentos que serão realizados, as linhas são todas analisadas e supervisionadas, assim como os setores de embalagem e armazenagem. Deve estar presente nas linhas as escrituras do Alcorão Sagrado, para diferenciá-las das outras e demonstrar o respeito aos ritos islâmicos pertinentes ao conceito Halal.

Os abatedores utilizam um uniforme com o nome da certificadora caracterizando que eles atuam na linha produtiva Halal.

Antecedentemente ao abate o transporte dos animais deve ser realizado sempre promovendo o bem estar destes. No Brasil o modal mais utilizado para o transporte das aves até os abatedouros e frigoríficos é o rodoviário realizado por caminhões devidamente inspecionados e de acordo com as normas de transporte do Brasil. Salientando que estes veículos só devem ser utilizados para transportar os animais que são destinados ao abate Halal. Portanto, não pode ser realizado o transporte de outros animais para que não haja a ocorrência de uma contaminação cruzada. Explicou-se durante a consulta que a contaminação cruzada pode ser caracterizada pelo contato com tudo que não é Halal.

Todo este processo é fiscalizado pela certificadora Halal e são realizados relatórios que promovem o controle dos procedimentos.

É obrigatório observar se os animais estão com fome ou sede, eles deves ser devidamente saciados antes de serem abatidos.

Após o processo de abate é realizada uma supervisão para confirmar a morte dos animais e verificar as linhas de produção, tudo realizado por mão de obra muçulmana fornecida pela certificadora.

Duas das principais exigências estão relacionadas ao isolamento e destaque entre as produções Halal e não Halal, frisando que o destaque deve ser feito por intermédio da utilização de carimbos e etiquetas, as caixas devem conter o nome da certificadora com o intuito de não ocorrer a mistura com as produções não Halal. $O$ isolamento e o destaque possuem como função objetiva promover maior facilidade nos processos de armazenamento, carregamento e transporte.

Os locais de armazenagem ou câmaras frias dos produtos Halal também devem ser utilizados de forma única e exclusiva para os produtos Halal e se manterem livres de contaminantes. Após os locais de armazenagem serem vistoriados de acordo com os padrões estabelecidos pela certificadora, os produtos são retirados e transportados pelo modal rodoviário até os portos de Paranaguá e Santos, localizados no Paraná e em São Paulo respectivamente. Onde são embarcados os contêineres também segregados apenas para o embarque Halal que vão ser transportados de navio para os países importadores. Este processo também é fiscalizado de maneira rigorosa com o propósito de que se mantenha um padrão adequado no transporte dos produtos Halal e visando a integridade dos produtos.

Durante os processos de transporte é necessário seguir critérios e cuidados, os envolvidos devem se atentar até mesmo com a devida higienização das mãos, se tocarem 
em produtos não Halal é necessário lavar as mãos para então manusear a carga Halal.

O colaborador garante que sempre haverá algum inspetor em todos os processos da cadeia Halal, para assegurar que tudo é devidamente respeitado e seguido criteriosamente. Assim é possível manter a credibilidade e aumentar o nível de reconhecimento da certificadora.

Há uma estratégia na qual a certificadora e as empresas exportadoras da carne de frango Halal se esforçam em se fazer cumprir todas as condicionantes da exportação Halal.

\section{RESULTADOS E DISCUSSÃO}

Por intermédio das informações coletadas foi possível perceber que, a certificadora possui como responsabilidade frente aos países islâmicos importadores assegurar que a carne de frango Halal exportada é proveniente de uma cadeia lícita, desde os suprimentos até o transporte em navios aos destinos finais. Logo, o processo Halal deve ser devidamente cumprido em todos os pontos e supervisionado rigorosamente.

A supervisão deve ocorrer não somente para verificar as condições de abate, mas sim o controle da qualidade e todos os estágios da produção até o carregamento. Tudo é exclusivamente Halal para que assim se torne mais fácil garantir que não haja alguma mistura ou contaminação cruzada (contato com produto não Halal)

Os transportadores têm de se manter atentos quanto ao carregamento ou embarque dos produtos.

Qualquer falha nas operações pode ser identificada como um grande problema e refletir diretamente na confiabilidade dos importadores.

Existe um sistema de rastreabilidade em toda a cadeia que possibilita garantir a segurança dos produtos Halal e que é controlado pelo órgão certificador, para evitar problemas com os países nesse sentido. As empresas produtoras junto com a certificadora realizam uma excelente integração ao considerar as condicionantes da exportação para os países muçulmanos.

\section{CONSIDERAÇÕES FINAIS}

A credibilidade na exportação da carne de frango Halal brasileira depende do grande rigor necessário no processo de abate e uma potente supervisão em todos os pontos da produção. Além da separação correta durante a armazenagem dos produtos depois do abate e um sistema eficiente de rastreabilidade presente em toda a cadeia Halal. A certificação Halal faz com que todo este controle extremamente necessário seja realizado em conformidade com a Jurisprudência Islâmica e que ele não se torne um problema ou uma barreira de mercado, mas sim uma oportunidade.

E são certificadoras como a consultada no artigo que colaboram com a liderança do Brasil neste cenário de exportação e garantem a confiabilidade.

Todos os procedimentos realizados para garantir o cumprimento das especificidades da produção Halal são efetivos positivamente e dificilmente ocorrem problemas durante a exportação.

Vimos que a certificadora Halal analisada juntos com as demais existentes no Brasil objetivam tornar o país no maior exportador de produtos Halal do mundo, abrangendo diferentes setores.

E ao analisar as condicionantes e as particularidades da exportação da carne de frango Halal, também foi possível perceber como o conceito está em expansão em outros segmentos, além do alimentício. Logo, os setores farmacêutico, cosmético, de produtos industrializados e outros estarão incorporando a prática deste conceito. Além disso, existe também o crescimento do consumo de produtos Halal por não muçulmanos por ser visto como uma opção mais saudável de consumo.

Portanto, da mesma maneira que a certificação incorpora aspectos ligados com a religião e segurança alimentar, existem pontos críticos que norteiam a cadeia logística neste tocante. Para garantir a integridade dos produtos se faz necessário o desenvolvimento de sistemas de controle e supervisão em todos os pontos da produção. O papel da certificadora é garantir que todos os requisitos são atendidos.

Particularmente, há uma crescente ambição em assegurar a integridade dos produtos Halal ao longo de toda a cadeia. As empresas exportadoras se mostram bastante 
empenhadas em atender as condicionantes relacionadas à logística para exportar seus

\section{REFERÊNCIAS}

[1]. CÂMARA DE COMÉRCIO ÁRABEBRASILEIRA - CCAB. Brasil discute padrão de abate halal com Arábia Saudita. 2018. Disponível em: $\quad<$ http://www.ccab.org.br/pt/noticias/brasildiscute-padrao-de-abate-halal-com-arabiasaudita/>. Acesso em 25 de março de 2018.

[2]. CENTRO DE DIVULGAÇÃO ISLÂMICA DA AMÉRICA LATINA - CDIAL HALAL. O que é um produto Halal, 2017. Disponível em: $<$ http://www.cdialhalal.com.br/o-que-e-um-produtohalal/>. Acesso em 2 de março de 2018.

[3]. CENTRO DE DIVULGAÇÃO ISLÂMICA DA AMÉRICA LATINA - CDIAL HALAL. O que é um alimento Halal, 2017. Disponível: $<$ http://www.cdialhalal.com.br/o-que-e-umalimento-halal/>. Acesso em 2 de março de 2018. CENTRO DE DIVULGAÇÃO ISLÂMICA DA AMÉRICA LATINA - CDIAL HALAL. O abate Halal, $2017 . \quad$ Disponível em: $<$ http://www.cdialhalal.com.br/o-abate-halal/> Acesso em 2 de março de 2018.

[4]. CENTRAL ISLÂMICA BRASILEIRA DE ALIMENTOS HALAL- CIBAL HALAL. Halal: Tendência mundial para quem busca novos mercados. Revista Food Ingredients Brasil, n. 10, 2009.

[5]. FALCO, Bárbara Toledo; LUCENA, Gabriela Gaio; STTETINER, Caio Flávio; PAIVA, Donizetti Leonidas. Condicionantes das Exportações Brasileiras de Carne Bovina Halal, SADSJ - South American Development Society Journal, v.1, n.1, 2015.

[6]. FEDERACÃO DAS ASSOCIAÇÕES MUÇULMANAS DO BRASIL - FAMBRAS HALAL. Conceito Halal, 2017. Disponível em: < produtos, o que as tornam ainda mais atuantes no cenário.

http://www.fambrashalal.com.br/\#./conceito-halal/>. Acesso em 2 de março de 2018.

[7]. FEDERACÃO DAS ASSOCIAÇÕES MUÇULMANAS DO BRASIL - FAMBRAS HALAL. Como Certificar, 2017. Disponível em: <http://www.fambrashalal.com.br/\#./comocertificar/>. Acesso em 2 de março de 2018.

[8]. GIL, Antônio Carlos. Como elaborar projetos de pesquisa. 4. Ed. São Paulo: Atlas, 2007.

[9]. MALHOTRA, Naresh K. Introdução a Pesquisa de Marketing. São Paulo: Pearson Prentice Hall, 2005.

[10]. MESSAGI, Angelino. Princípios Básicos de Bem Estar Animal e Abate Humanitário de Frangos de Corte. 2014. Trabalho de Conclusão de Curso (Curso de Especialização em Produção, Tecnologia e Higiene de Alimentos de Origem Animal - Faculdade de Veterinária, Universidade Federal do Rio Grande do Sul, Porto Alegre, 2014.

[11]. RIBEIRO, Renata vaz. Abate Halal e Suas Principais Características. 2014. Monografia (Curso de Zootecnia) - Unidade Universitária São Luís de Montes Belos, Universidade Estadual de Goiás, São Luís de Montes Belos, 2014

[12]. ISLAMIC HALAL. Mercado. Disponível em: http://www.islamichalal.com.br/mercados.php Acesso em: Acesso em 2 de março de 2018.

[13]. TEDESCO, João Carlos. "Com a faca no pescoço": Trabalho, mercado e religião. A certificação Halal e os imigrantes nos frigoríficos de aves no sul do país. Revista Signos - UNIVATES, Lajeados, n. 2, p.157-177, 2016. 


\section{Gapítulo 10}

\section{APLICAÇÃO DA LOGÍSTICA AEROPORTUÁRIA NO ESTUDO COMPARATIVO ENTRE OS SISTEMAS DE CONTROLE MANUAL E AUTOMATTICO DO FLUXO DE VEICULOS NO TERMINAL DE CARGAS- ESTUDO DE CASO.}

\section{Thays dos Santos Vasconcelos \\ Samuel Victor Ricardo da Silva \\ Celia de Lima Pizolato}

Wanny Arantes Bongiovanni Di Giorgi

Resumo: Este trabalho aborda o estudo comparativo entre o controle manual e o controle automático do fluxo de veículos do terminal de cargas de uma companhia aérea no ambiente aeroportuário. A pesquisa é realizada com o objetivo de propor de maneira clara uma proposta de melhoria de gestão da mobilidade de veículos de carga no aeroporto. O problema identificado situa-se no tempo de registro manual do veículo que é superior ao seu tempo de permanência. A metodologia utilizada para a solução do problema apoia-se no levantamento da literatura sobre o tema e inclui a pesquisa de campo na forma de estudo de caso de uma empresa específica, que não será identificada por motivo de ética e confidencialidade. O estudo indica uma vantagem competitiva para o sistema de controle automático do processo.

Palavras-chave: Logística Aeroportuária. Fluxo de veículos no terminal de cargas. Sistemas de controle. 


\section{INTRODUÇÃO}

Os controles de acesso propriamente ditos são meios que estabelecem restrições a circulação e/ou acesso. Este tipo de controle é o que nos interessa, pois nele estão contidas, em conjunto com a ação humana, barreiras físicas que restringem acesso a determinadas áreas como cancelas, catracas, portas, portões e torniquetes. Essas barreiras físicas podem ser automatizadas de tal forma utilizando-se recursos de eletrônica, eletromecânica e programas de computadores de forma que a ação humana utilizada para controle das mesmas seja reduzida a um posto de monitoramento, uma vez que a solicitação de acesso é feita com a aproximação do cartão da pessoa que deseja acessar determinada área. (BRASILIANO, 2003, p.19)

Ao falarmos de controlador de acesso, temos que ressaltar sua importância para a administração da empresa, pois são esses dados diários que podem influenciar em melhorias a curto a e longo prazo na empresa, visando maior capacidade de atendimento, controle e segurança das pessoas que exercem esse serviço.

Um atendimento diferenciado pode garantir a fidelidade do cliente pela comodidade e rapidez no processo, sendo comprovado que essa fidelidade acarreta novas oportunidades de alcance a novos clientes e novos negócios, podemos dizer que investir em tecnologia para essa área da empresa pode ser muito favorável ao crescimento da corporação.

\subsection{PROBLEMÁTICA}

O problema identificado é:

"O controle manual do fluxo de veículos no terminal de cargas do aeroporto leva mais tempo do que o próprio fluxo de veículos. A falta de sincronia entre o tempo gasto no controle manual das operações e no tempo gasto pelo fluxo de veículos, culmina na formação de filas de espera de veículos para sair do terminal".

\subsection{HIPÓTESE}

A hipótese para a solução do problema é:

"Se o controle do fluxo de veículos no terminal de cargas do aeroporto for realizado com a utilização da tecnologia de informação automática, em substituição aos controles manuais vigentes, então o tempo de controle não atrasará o fluxo de veículos no terminal de cargas do aeroporto".

\section{JUSTIFICATIVA}

A logística empresarial trata de todas as atividades de movimentação e armazenagem, que facilitam o fluxo de produtos desde o ponto de aquisição da matéria prima ate o ponto de consumo final, assim como dos fluxos de informação que colocam os produtos em movimento, com o propósito de providenciar níveis de serviço adequados aos clientes a um custo razoável (BALLOU, 2006, Pg.27).

Fleury e Fleury (2000) complementa a definição de logística de Ballou (2006) classificando-a como um elemento diferenciador que oferece vantagem competitiva, destacando o surgimento do conceito de gerenciamento da cadeia de suprimentos e com isso o conceito da logística empresarial.

A Logística 4.0 aplica os princípios tecnológicos característicos da $4^{a}$ Revolução Industrial à estrutura da prestação de serviços logísticos, utilizando os seguintes princípios: operação em tempo real, virtualização, descentralização, micros serviços e modularidade que inclui: Big Data Analytics / Machine Learning e Segurança dos Dados (CHIQUETO, 2017. Pag. 01).

O autor comenta ainda que já estamos inseridos no contexto desta grande revolução industrial e logística, e que devemos ficar atentos à competitividade dos negócios, pois a Logística 4.0 já uma realidade.

Não se justifica a manutenção do sistema manual ao controle do fluxo de veículos no terminal aeroportuário de cargas, a menos que a empresa não queira ser competitiva no mercado.

\subsection{OBJETIVO GERAL}

O objetivo geral deste trabalho é apresentar o problema logístico de uma empresa de transporte de carga que opera no terminal aeroportuário e propor uma solução com apoio da tecnologia da informação. 


\subsection{OBJETIVOS ESPECÍFICOS}

- Os objetivos específicos incluem as etapas:

- Identificar as variáveis envolvidas no problema e na hipótese;

- Apresentar o aporte teórico existente sobre o tema;

- Realizar um estudo de caso real, porém com empresa não identificada;

- Apresentar possível solução para o problema;

- Identificar as limitações da empresa no tocante à mudança de método de controle;

- Indicar a continuidade da pesquisa.

\subsection{METODOLOGIA}

Este trabalho está estruturado em seis seções, sendo a primeira esta introdução seguida da justificativa, que apresenta os objetivos geral e específicos e os aspectos metodológicos que caracterizam o método de pesquisa que possibilitou gerar os resultados discutidos na quarta seção. A terceira seção apresenta o referencial teórico que aborda sucintamente conceitos fundamentais para 0 entendimento deste artigo, assim como o estudo de caso ilustrativo sobre o tema. Após o referencial teórico, apresentam-se na quarta seção os resultados e a discussão dos dados relativos ao estudo de caso. A quinta seção apresenta as considerações finais, seguidas pelas referências das obras consultadas no decorrer do desenvolvimento do trabalho.

\section{EMBASAMENTO TÉORICO}

A metodologia utilizada foi o estudo de caso através de uma pesquisa exploratória com relato de estudo de campo. Segundo Gil (2010, p.27), as pesquisas exploratórias têm como objetivo proporcionar maior familiaridade com o problema, com vistas a torná-lo mais explícito ou a construir hipóteses, porém foi feita uma observação em horário de serviço. Segundo Gil (2011, p. 100) "A observação apresenta como principal vantagem, em relação às outras técnicas, a de que os fatos são percebidos diretamente, sem qualquer intermediação." Duas formas distintas da observação: a natural , o observador pertence ao grupo que investiga; e a artificial, o observador se integra ao grupo com objetivo de realizar uma investigação.

Foi utilizado a pesquisa-ação para embasamento do estudo em campo, na pesquisa-ação as intervenções e a produção do conhecimento se inter-relacionam. Nesse sentido, Thiollent (2011 p. 19-39) recomenda, sempre que possível, um equilíbrio na definição de objetivos práticos, que conduzirão às soluções, e de objetivos de conhecimento, como a identificação de representações, habilidades, entre outros aspectos, que contribuirão, por sua vez, para esclarecer a problemática em evidência e melhor conduzir as ações transformadoras.

\section{RESULTADOS E DISCUSSÃO}

\subsection{FORMA DE REGISTRO ATUAL DA COMPANHIA ESTUDADA}

Segundo pesquisa feita em campo, os controladores de acesso desse terminal preenche em média 30 folhas diariamente, campo por campo, os mesmos informam a dificuldade dos registros e a fragilidade na segurança dos dados, já que as folhas ficam expostas abertamente.

Com isso o processo de controle se define na forma do seguinte algoritmo de fluxo de veículos no terminal aeroportuário:

O veiculo chega no terminal de cargas;

O controlador de acesso registra manualmente em folha impressa os seguintes dados: logo após o preenchimento do formulário de controle o veiculo é liberado para entrar no Terminal de Cargas;

Quando o motorista termina o seu trabalho, ele precisa esperar o controlador de acesso dar baixa no horário de saída dele, antes de ser liberado;

Por fim o motorista é liberado e o veiculo pode sair do Terminal.

\subsection{TEMPO NO REGISTRO NA ENTRADA}

O sistema de controle de acesso precisa ser rápido e seguro já que ele lida constantemente com chegadas e saídas de veículos e pessoas no local, para isso precisamos de uma estrutura tecnológica que seja capaz de administrar esse fluxo diariamente em tempo mínimo afim de evitar o formamento de filas na entrada da empresa. 
Figura 1. Formulário para controle manual do fluxo de veículos no Terminal de Cargas aeroportuário.

\begin{tabular}{|c|c|c|c|c|c|c|c|c|c|c|}
\hline Data & Entrada & Hora de saída & $\begin{array}{l}\text { Véculo / Numero } \\
\text { de Identificacão }\end{array}$ & Veículo Placa & Motorista & $\begin{array}{l}\text { Documento } \\
\text { RG/RNE }\end{array}$ & Empresa & \multicolumn{3}{|c|}{ Setor Procurado } \\
\hline 1 & $:$ & $:$ & & & & & & Embarque & Retira & Outros \\
\hline 1 & $:$ & $:$ & & & & & & 11 & 11 & 11 \\
\hline 1 & : & $:$ & & & & & & 11 & 11 & 11 \\
\hline 1 & $:$ & : & & & & & & ( ) & 11 & 11 \\
\hline 1 & $:$ & $:$ & & & & & & 11 & 11 & 11 \\
\hline 1 & $:$ & $:$ & & & & & & 11 & 11 & 11 \\
\hline 1 & : & $:$ & & & & & & 11 & 11 & 11 \\
\hline 1 & $:$ & $:$ & & & & & & 11 & 11 & 11 \\
\hline 1 & $:$ & $:$ & & & & & & 11 & 11 & 11 \\
\hline 1 & $:$ & $:$ & & & & & & 11 & 11 & 11 \\
\hline 1 & $:$ & : & & & & & & 11 & 11 & 11 \\
\hline 1 & $:$ & : & & & & & & 11 & 11 & 11 \\
\hline 1 & $\vdots$ & $:$ & & & & & & 11 & 11 & 11 \\
\hline 1 & $:$ & $:$ & & & & & & 11 & 11 & 11 \\
\hline 1 & : & : & & & & & & 11 & 11 & 11 \\
\hline
\end{tabular}

Fonte: Empresa que atua no Terminal de Cargas do aeroporto, 2018.

Feito uma observação na forma de atendimento da companhia aérea, foram verificadas falhas no processo de controle, pois sua forma de registro é feita manualmente pelos controladores em papel impresso. Segundo pesquisa em campo foi constatado que no dia-a-dia da empresa, ela recebe normalmente 1 Veiculo trazendo carga para despacho no terminal a cada um (1) minuto, nisso os controladores fazem esse registro manualmente preenchendo campos na folha impressa, sendo esse veiculo liberado somente após esse cadastro.
Esse tempo de atendimento dura em média 1 minuto e 30 segundos, se não houverem complicações no momento do preenchimento na folha, porém, como estamos falando de uma terminal de cargas, temos que ressaltar que constantemente chega veículos com carga para despacho, quando essa quantidade de veículos excede de 1 por minuto, o tempo de atendimento individual aumenta criando assim fila (gargalo) na porta do terminal e causando irritação por parte dos motoristas.

Figura 2. Formulário preenchido do fluxo de veículos no período amostral de 1 hora e 50 minutos

\begin{tabular}{|c|c|c|c|c|c|} 
Horário & $\begin{array}{c}\text { Quant. De } \\
\text { Veiculos }\end{array}$ & $\begin{array}{c}\text { Tempo de } \\
\text { atendimento } \\
\text { MIN }\end{array}$ & Horário & Quant. De Veiculos & $\begin{array}{c}\text { Tempo de } \\
\text { atendimento } \\
\text { MIN }\end{array}$ \\
\hline $09: 12$ & 1 & $00: 47$ & $10: 04$ & 1 & $00: 42$ \\
\hline $09: 15$ & 1 & $01: 02$ & $10: 06$ & 1 & $00: 41$ \\
\hline $09: 19$ & 1 & $01: 14$ & $10: 07$ & 1 & $00: 45$ \\
\hline $09: 20$ & 1 & $01: 03$ & $10: 13$ & 1 & $00: 50$ \\
\hline $09: 22$ & 1 & $01: 18$ & $10: 16$ & 1 & $00: 46$ \\
\hline $09: 28$ & 1 & $00: 55$ & $10: 19$ & 3 & $02: 30$ \\
\hline $09: 31$ & 1 & $01: 07$ & $10: 22$ & 1 & $00: 53$ \\
\hline $09: 33$ & 1 & $01: 32$ & $10: 23$ & 1 & $01: 00$ \\
\hline $09: 35$ & 4 & $04: 02$ & $10: 25$ & 1 & $01: 10$ \\
\hline $09: 38$ & 1 & $01: 02$ & $10: 27$ & 2 & $03: 30$ \\
\hline $09: 44$ & 1 & $01: 06$ & $10: 39$ & 1 & $01: 30$ \\
\hline $09: 52$ & 2 & $02: 20$ & $10: 41$ & 1 & $01: 30$ \\
\hline $09: 55$ & 3 & $03: 30$ & $10: 47$ & 1 & $01: 33$ \\
\hline $09: 59$ & 1 & $01: 20$ & $10: 48$ & 1 & $00: 50$ \\
\hline $10: 00$ & 1 & $00: 46$ & $10: 51$ & 2 & $01: 57$ \\
\hline
\end{tabular}

Fonte: Empresa que atua no Terminal de Cargas do aeroporto, 2018 


\subsection{TEMPO DE ESPERA PARA LIBERAÇÃO DA SAIDA}

No momento em que o controlador de acesso está registrando o veiculo para dar acesso ao terminal de cargas, os veículos que já estão dentro desse terminal ficam esperando essa liberação para que eles possam sair, pois o controlador precisa dar baixa na folha para registrar a saída do veiculo para administração da empresa. Quando isso acontece, é formado filas de veículos de grande e pequeno porte dentro do terminal, acarretando assim mais um tempo de espera por parte dos motoristas no momento da saída, essas filas acabam prejudicando quem tenta entrar pois a passagem fica bloqueada pelos veículos que estão saindo do terminal, influenciando mais uma vez um tempo de espera por parte dos motoristas que foram liberados.

\subsection{INFLUENCIA DO CLIMA NO CONTROLE DE ACESSO E SEGURANÇA DOS DADOS}

Devido o a forma de registro ser manual e em folha impressa, temos que ressaltar que o clima influencia ainda mais o tempo de atendimento, pois os controladores saem de seus postos e se dirigem até o veiculo para realizar o registro, ressaltando que o registro é feito em folha, em um dia chuvoso esse processo é totalmente prejudicado, pois o risco da folha molhar no momento é extremamente alto, requerendo do controlador uma atenção dobrada, por que se essa folha molhar ele pode perder todo o registro feito no dia e ainda não conseguir recuperar seus dados.

Podemos assim perceber que o controle de acesso é totalmente vulnerável, fato que não devia acontecer já que isso pode prejudicar a imagem da empresa, caso algum cliente requeira algum dado desse controle ou se até mesmo a empresa quiser fazer algum levantamento para tomada de decisão.

\subsection{VANTAGENS NA IMPLANTAÇÃO DE UM CONTROLADOR DE ACESSO ELETRONICO}

A implantação de um controlador de acesso eletrônico reduziria de forma significativa 0 tempo de atendimento aumentando a performasse da empresa, a competitividade com outras cias, já que esse atendimento seria diferenciado e traria comodidade aos motoristas e aumentaria de forma visível a capacidade de atendimento por minuto, sem diferenciação de modais. Reduziria o uso de funcionários, segundo (TEXEIRA 2011) não exige contato físico, dado que todo o processo se da totalmente de forma automática não há nenhuma necessidade de intervenção humana tanto no processo de entrada quanto no de saída. Os funcionários poderiam ser deslocados para uma área que precisasse de mais atenção.

Haveria maior segurança das informações coletadas já que somente pessoas autorizadas pela companhia teria acesso, maior controle em tempo real

\subsection{DIFICULDADES NA IMPLANTAÇÃO OBSERVANDO O ESTADO ATUAL DA COMPANHIA}

Para que a empresa tenha um controle de acesso eletrônico, ela precisa estar disposta a investir em infraestrutura tanto física como tecnológica. Essa estrutura requer um investimento e planejamento na sua implantação, pois, um terminal de cargas é atuante $24 \mathrm{hs}$ por dia tendo recebimento de cargas constantemente, interromper um horário de serviço ou um dia para que esse sistema fosse implantado já que a empresa não possui nem infraestrutura e nem tecnologia poderia ser Catastrófico para os clientes que dependem dos serviços da empresa. Nisso, a corporação teria que ter um planejamento logístico muito eficiente para deslocar os clientes para outra área da empresa para fazer o recebimento das cargas enquanto o sistema está sendo implantado. Outro fator muito relevante seria o treinamento dos funcionários para o uso desse novo sistema, evitando erros ou frustrações no momento da recepção, já que os clientes estão habituados ao registro de dados antigo.

\section{CONSIDERAÇÕES FINAIS}

Com base na pesquisa-ação, feitas em campo, foi considerado que a implantação de um sistema de controle de acesso eletrônico é viável, tendo em vista o segmento da empresa, em um terminal de cargas aeroportuário, com fluxos constantes de veículos, é de suma importância que essa forma de recepção seja simplificada afim de 
proporcionar maior objetividade e rapidez na liberação de entrada e saída de veículos.

Esse sistema traria maior segurança na recepção dos veículos e dos funcionários que exercem esse serviço e comodidade de uma recepção mais ágil, podemos ver que os investimentos feitos nessa forma de recepção mais tecnológica traria benefícios para ambas as partes, como maior capacidade de atendimento por minuto, diferenciação competitiva em relação a outras companhias trazendo atenção de novos clientes à corporação pela diferenciação e eficácia nesse fluxo e extinção do uso habitual de papel pelos funcionários.

A empresa não teria problemas com a meteorologia, já que o sistema eletrônico faria - registro automaticamente sem a interferência humana, deixando os funcionários em posições estratégicas em pontos que a empresa achar importante ou necessária. A inclusão de novas tecnologias abrirá novos olhares e ajudarão a companhia a se transformar em uma empresa mais tecnológica, trazendo novidades para seu dia-a-dia e conhecimentos que adicionaram ajustes em outras áreas da corporação futuramente.

\section{REFERÊNCIAS}

[1]. ANTHONY, Robert; GOVINDARAJAN, Vijay. Sistemas de controle Gerencial. São Paulo: AMGH, 2011.

[2]. BALLOU, R.H. Gerenciamento da cadeia de suprimentos/logística empresarial. $5^{\underline{a}}$ ed. Porto Alegre/SC: Bookman, 2006.

[3]. BOWERSOX, Donald; CLOSS, David. Logística empresarial: o processo de integração da cadeia de suprimentos. São Paulo: Atlas, 2011.

[4]. CHIQUETO, Gilson. TMS aplicado à Logística 4.0. (2017). Disponível em: < http://www.transpobrasil.com.br/2017/09/12/tmsaplicado-a-logistica-4-0/>. Acesso em: 12 fev. 2018

[5]. FLEURY, Afonso; FLEURY, Maria Tereza Leme. Estratégias empresariais e formação de competências. São Paulo: Atlas, 2000.

[6]. COSTA, Ariana de Sousa Carvalho; SANTANA, Lídia Chagas de; TRIGO, Antônio Carrera. (2015). Qualidade do Atendimento ao Cliente: um grande diferencial competitivo para as organizações. Disponível em <
O estudo demonstra que o controle manual do fluxo de veículos no terminal de cargas do aeroporto pode e deve ser substituído por um sistema integrado, automático, de forma a solucionar o problema de formação de filas de veículos na saída do terminal, validando a hipótese.

Como este trabalho se trata da comunicação de uma pesquisa que ainda está em andamento, os autores propõem a sua continuidade na elaboração de um projeto logístico para a implantação e implementação de um sistema integrado do controle do fluxo de veículos no terminal de cargas. O projeto terá início com um levantamento dos sistemas integrados existentes no mercado e a escolha de qual será o mais indicado, levando em consideração tanto o fornecedor quanto o custo de aquisição. Após a identificação do sistema, será estudada sua capacidade de funcionamento, e o cálculo do aumento da capacidade de atendimento do terminal, com consequente aumento da receita. A partir deste ponto do estudo, será possível determinar o tempo do retorno do investimento no sistema integrado, com a relação custo/benefício.

http://www.cairu.br/riccairu/pdf/artigos/2/10_QUAL/ DADE_ATEND_CLIENTE.pdf > Acesso em 12 abril. 2018.

[7]. SOUSA, Marcelo Barbosa de. Controle de Acesso: conceitos, tecnologias e benefícios. São Paulo: Sicureza, 2010.

[8]. TEIXEIRA, Sebastião. Gestão Estratégica. São Paulo: Escolar, 2011.

[9]. THIOLLENT, Michel Jean Marie; COLETTE, Maria Madalena. Pesquisa-ação, formação de professores e diversidade. (2011). Disponível em: < https://www.researchgate.net/publication/28506594 6_bPesquisa-

acao_formacao_de_professores_e_diversidade> Acesso em: 05 fev. 2018.

[10]. TRIPP, David. Pesquisa-ação: uma introdução metodológica. (2005) Disponível em: <http://www.scielo.br/pdf/ep/v31n3/a09v31n3.pdf>. Acesso em: 05 fev. 2018

[11]. THIOLLENT, M. Metodologia da pesquisaAção. 18. ed. São Paulo: Cortez, 2011. 


\section{Capítulo 11}

\section{CONCEITO COLABORATIVO NA LOGÍSTICA BRASILEIRA: UMA ANÁLISE SOBRE UM APLICATIVO COMO FERRAMENTA DE INTEGRAÇÃO ENTRE EMBARCADORES E TRANSPORTADORES AUTONNOMOS}

\section{Caio Fabio Ferraz, Santos}

\section{Marina Codo Andrade Teixeira}

Paulo Cesar Giuliani

Resumo: $O$ presente artigo tem por finalidade estudar o conceito colaborativo aplicado a logística brasileira, usando como objeto de estudo o aplicativo Truckpad, que atua desde 2013 no Brasil. Para atingir o objetivo de pesquisa acima descrito, foi feito um estudo teórico sobre a economia compartilhada, consumo colaborativo, logística colaborativa e a caracterização do transporte colaborativo de cargas. Após a pesquisa bibliográfica, foi realizado uma análise a respeito do surgimento do aplicativo, como ele funciona, os seus principais objetivos e como ele pode agilizar, diminuir os custos de operações logísticas e ainda diminuir alguns trâmites burocráticos tangentes a contratação de um serviço de frete. A partir das informações, foi possível confrontar a teoria estudada com a prática do aplicativo e efetuar uma análise do seu desempenho. Os resultados apontam que o uso da aplicação pode ser um escape para a vida dos embarcadores, tornando muito prático o processo de contratação de um frete, sendo esta contratação realizada diretamente entre as partes sem a necessidade de intermediários.

Palavras-chave: Economia compartilhada, logística colaborativa, transporte colaborativo de cargas. 


\section{INTRODUÇÃO}

O presente artigo tem por finalidade estudar - conceito colaborativo aplicado a logística brasileira, utilizando como objeto de estudo - aplicativo móvel brasileiro Truckpad, que está atuando desde 2013 no território nacional.

O aplicativo foi selecionado com base na sua tecnologia inovadora, números cada vez maiores de usuários, a recente "onda" por aplicativos móveis que tragam praticidade para consumidores e empresas, além de toda a experiência no transporte de cargas carregada pelo seu idealizador.

O conceito colaborativo é uma realidade cada vez mais presente no cotidiano das pessoas e das corporações. Os avanços tecnológicos na área de aplicações móveis estão fazendo surgir inúmeras soluções para problemas ou situações práticas em que indivíduos lidam na sociedade. A globalização e crescimento do número de usuários da internet tanto de aplicativos móveis, está fomentando em grande escala o desenvolvimento destas soluções. Pelo decorrer disso, passou a ser mais discutido, difundido e estudado o conceito de economia compartilhada, que está presente em aplicativos muito populares e presentes no dia-a-dia do brasileiro, como o Uber, Airbnb dentre outros.

Os usuários destas soluções estão interessados em utilizar serviços e adquirir produtos com conforto e comodidade, realizando apenas alguns toques nas telas de seus smartphones. E é justamente isto que o aplicativo a ser estudo tem por objetivo: gerar conforto e comodidade para seus usuários, que podem ser embarcadores ou transportadores autônomos, agilizando e beneficiando de um lado o prestador do serviço e do outro aquele que irá adquirir o serviço - serviço este que é o transporte de cargas, sem a necessidade de um intermediador nesta operação.

Pelo exposto acima, o tema justifica-se pela possível oportunidade de redução de custos, burocracia e aumento da agilidade dos processo envolvendo a compra de um frete. Com a pressão cada vez maior dos consumidores exigindo excelentes níveis de serviço, é apresentado o aplicativo Truckpad como possível escape para a vida dos embarcadores.
O método de pesquisa utilizado que embasa o artigo trata-se de um estudo de caráter qualitativo. $O$ estudo de caso segundo Voss, Tsikriktsis e Frohlich (2002 apud FREITAS E JABBOUR, 2010) é uma história de um fenômeno passado ou atual, elaborado a partir de múltiplas fontes de prova, que pode incluir dados da observação direta e entrevistas sistemáticas, bem como pesquisas em arquivos públicos e privados. Com isso, como o artigo retratará de uma única realidade de uma empresa - no caso, o Truckpad - sua categorização se adequa. Já a abordagem qualitativa ainda segundo os autores ocorre quando a finalidade é explicar ou descrever um evento ou uma situação sem a realização de tratamento estatístico. A pesquisa se enquadra nesse método de pesquisa por conta de sua análise ser feita com base em documentos e entrevistas.

Para atingir o objetivo de pesquisa, foi realizado um estudo teórico a respeito dos conceitos de economia compartilhada, consumo colaborativo, logística colaborativa e por fim a caracterização do transporte colaborativo de cargas. Após a pesquisa bibliográfica, foi realizado uma análise a respeito do surgimento do aplicativo, como ele funciona, os seus principais objetivos e como ele pode agilizar, diminuir os custos de operações logísticas e ainda diminuir alguns trâmites burocráticos tangentes a contratação de um serviço de frete. A partir das informações, foi possível confrontar a teoria estuda com a prática do aplicativo e efetuar uma análise do seu desempenho.

\section{REFERENCIAL TEÓRICO}

\subsection{A ECONOMIA COMPARTILHADA}

Denominamos de economia compartilhada ou colaborativa um recente movimento que por meio de tecnologias digitais de comunicação e informação fez surgir um conceito que objetiva reduzir desperdícios, aumentar a capacidade de eficiência na utilização dos recursos naturais e combater o consumismo extremo (FNQ - FUNDAÇÃO NACIONAL DA QUALIDADE, 2016). De acordo com Gansky (2011), a economia colaborativa e a rede formada por ela se fazem existir por intermédio do consumo consciente e do aproveitamento otimizado dos recursos disponíveis existentes, primordialmente por meio de organizações 
que conectam as pessoas umas às outras e que fornecem o acesso aos bens sem precisarmos adquiri-los. Acrescenta Gansky (2011) que o atrativo não está relacionado somente ao financeiro, mas também ao acesso a um serviço ou a um bem, de acordo com a necessidade.

Para a FNQ (2016), formas tecnologicamente inovadoras de negócios causam mudanças no contexto social e o surgimento de organizações, como o Airbnb (disposição de serviço colaborativo on-line que possibilita as pessoas de anunciarem, encontrarem e reservarem acomodações em lugares do mundo) e o Uber (empresa multinacional que promove a locomoção privada e transporte de passageiros).

Enfatiza Marin (2016) que as organizações brevemente citadas são ótimos exemplos de utilização do conceito compartilhado e/ou colaborativo e funcionam como estimuladores da conexão de pessoas desconhecidas com necessidades e interesses semelhantes.

Há também os negócios disruptivos que fazem com que os serviços já existentes e oferecidos sejam mais simples e de fácil acessibilidade, como o transporte de cargas, pessoas e contratação temporária de mão de obra (SILVEIRA, 2017). Silveira (2017) cita o TruckPad, Zipcar, 99taxis e entre outros negócios que compartilham, viabilizam e logram o valor dos bens e recursos.

\subsection{O CONSUMO COLABORATIVO}

A colaboração ocorre quando há indivíduos interagindo em qualquer atividade em conjunto, posto isso, a colaboração sempre se fez historicamente presente (FNQ, 2016). A tecnologia segundo Kotler, Kartajaya e Setiwaan (2010) viabiliza a propagação de informações, ideias e fornece espaço para os consumidores colaborarem com a criação de valor daquilo que consomem, impulsionando o crescimento do mercado criativo com uma visão mais dinâmica.

Ainda de acordo com Kotler, Kartajaya e Setiwaan (2010), conforme os consumidores se tornam cada vez mais colaborativos, culturais e espirituais, o caráter do mercado se modifica e isso é visível no marketing e nas mídias sociais.
A diferença entre o consumo colaborativo e a economia colaborativa é o intuito de cada um no final, enquanto um visa reduzir desperdício, combate ao consumismo e entre outros, o outro objetiva o compartilhamento de serviços e bens entre os indivíduos e maior consciência ao consumir (FNQ, 2016). Afirma Barros (2015) que a colaboração está em potencial crescimento, especialmente no segmento das mídias digitais.

De acordo com Kaufman e Roza (2013), a chave para o funcionamento dessa forma de consumo é o compartilhamento no qual os indivíduos procuram fazer uso de serviços e bens de forma distinta da tradicional com base na troca entre comprador e ofertador.

Segundo a Market Analysis (2015), cerca de $20 \%$ dos brasileiros conhecem o consumo colaborativo e que os moradores da região sudeste são os que menos estão familiarizados com a forma colaborativa de consumo.

A troca ou venda de produtos já utilizados são as mais comuns práticas, do mesmo modo que o compartilhamento de caronas e de serviços (MARKET ANALYSIS, 2015). Acrescenta Market Analysis (2015) que o Banco Itaú e OLX são destaques na memória do consumidor brasileiro com relação à empresas que já integram esse tipo de economia.

\subsection{LOGÍSTICA COLABORATIVA}

A logística colaborativa visa estabelecer um vínculo de colaboração entre os fornecedores, clientes, concorrentes e demais integrantes da cadeia logística por intermédio de uma relação de confiança entre eles (SILVA, PRADO E BARROS, 2013). Para Nicolini (2011), as ações logísticas que fomentam a integração dos participantes da cadeia por meio de tecnologias da informação e comunicação com o intuito de avançar estratégias e planos operacionais proporcionando benefícios aos consumidores com produtos e serviços melhores, acarretando vantagens competitivas para os participantes, integração em toda cadeia, troca de informações por intermédio do compartilhamento de recursos configuram a chamada logística colaborativa.

A logística colaborativa objetiva a redução dos custos de produção afim de reduzir o 
preço repassado ao cliente e para sua efetivação é primordial que haja a troca de informações, conhecimentos, competências e técnicas entre as organizações para potencializar sua competitividade com relação a concorrência (SILVA, PRADO E BARROS, 2013). Porém, segundo Silva, Prado e Barros (2013), atualmente a colaboração ainda é vista como algo complexo em decorrência da falta de confiabilidade entre organizações concorrentes, por fatores que dificultam a colaboração entre elas, como as diferentes culturas (tradições), recursos, instalações e nível de funcionários.

Um dos principais empregos da logística colaborativa é no transporte de cargas por meio do chamado transporte colaborativo que será abordado com maior ênfase adiante.

\subsection{TRANSPORTE COLABORATIVO DE CARGAS}

O transporte colaborativo trata do compartilhamento de um mesmo meio de transporte destinando à movimentação e distribuição de cargas (SILVA, ZAGO E COELHO, 2009). Esse é um dos principais pontos de ligação da logística colaborativa, pois abarca desde os fornecedores até os clientes, além disso, com a utilização do transporte colaborativo há chances de reduzir as ineficiências do transporte (SILVA, PRADO E BARROS, 2013). É importante enfatizar que as palavras de ordem da logística colaborativa, são compartilhar e colaborar, para que as estratégias diferenciadas possam engrandecer o desenvolvimento competitivo entre as concorrentes com benefícios maiores com relação às organizações que preferem agir de forma solitária.

De acordo com pesquisas realizadas pelo ILOS - Instituto de Logística e Supply Chain (2014), as empresas no Brasil gastam em média, $8,7 \%$ da receita líquida com os custos logísticos, tomando como pontos consideráveis gastos com transporte, estoque e armazenagem, fazendo com que haja um forte desejo de redução dos custos em questão. E ainda segundo o ILOS (2014) pode-se observar que, representando $55 \%$ dos custos, trata-se da maior conta de custos logísticos a de transporte, entre as principais contas.
Outro fator negativo com potencial para afetar os gastos, são as taxas altas de fretes de retorno vazios (PINTO et al., 2015). O que resulta em altos prejuízos financeiros, uma vez que há veículos de carga trafegando vazios ou parcialmente carregados. Essas viagens são dadas como perdidas aos proprietários de transportadoras (SECRETARIA DE TRANSPORTE DO ESTADO DE SÃO PAULO,

2006). Assim, conforme Botter, Tacla e Hino (2006), o transporte colaborativo possui potencial para se tornar uma grande ferramenta afim de alcançar objetivos relacionados a minimização de problemas referentes aos custos e prejuízos com transportes.

Como um meio de minimizar os problemas e otimizar o transporte, surgiu o CTM Collaborative Transportation Management, que é a gestão colaborativa de transporte, conceito que integra a nova onda da logística colaborativa (SILVA et al., 2009). De acordo com Pinto et al. (2015) visando reduzir ou eliminar as ineficiências nos processos de transporte, como o tempo de percurso, inventários, espaços, erros e distâncias, por meio da colaboração e compartilhamento de conhecimentos e informações. O conceito CTM passou a ser difundido em meados dos anos 2000 nos Estados Unidos, por meio do CPFR - Collaborative Planning, Forecasting and Replenishment.

No nível operacional o transporte colaborativo se dá ao aproveitar ou compartilhar o mesmo meio de transporte para um ciclo fechado ou circuito estático de movimentação e distribuição de cargas (BROWNING E WHITE, 2001). Logo, afim de gerar a carga de retorno, é necessário reunir os integrantes da mesma cadeia logística ou embarcadores que dispõem cargas complementares, cargas que possuam compatibilidade com o meio de transporte disponibilizado para a rota complementar (BOTTER, TACLA E HINO, 2006). Ainda destacam Botter, Tacla e Hino (2006) que planejamento estratégico, previsão de demanda, ressuprimento e execução física são as três categorias primordiais para a ocorrência de colaboração entre compradores, vendedores e transportadores.

A utilidade do CTM tem sido destacada por especialistas no que tange ao seu potencial de proporcionar redução nos custos das 
transações logísticas e riscos, aumento de desempenho no que se refere a serviço e capacidade, e tornar a cadeia de suprimentos mais plural e dinâmica (PINTO et al., 2015). Figueiredo e Eiras (2007) apontam os principais benefícios proporcionados pelo CTM: redução de trechos com veículos vazios e ociosos, aumento na consolidação da carga, redução nos tempos de carga e descarga, redução nos prazos de atendimento aos clientes (lead time) e aumento da disponibilidade dos produtos aos clientes.

\subsection{CUSTO DE TRANSPORTE E A TERCEIRIZAÇÃO COMO ALTERNATIVA DE REDUÇÃO DE CUSTO}

Uma das maiores preocupações para os profissionais de logística é o custo total das operações. A pressão por redução nos custos vem se tornando cada vez maior nas empresas e é necessário, dessa forma, encontrar soluções dentro de uma cadeia de suprimentos visando a redução destes custos. Um dos principais componentes dos custos logísticos é o custo relacionado a transporte. De acordo com Ballou (2009), o transporte normalmente representa o elemento mais importante dos custos logísticos de uma empresa, chegando a absorver de um a dois terços do custo logístico total. De acordo com Castiglioni e Nascimento (2014), destacam-se entre os elementos componentes do custo de transporte: depreciação do veículo, remuneração do capital, salário e gratificação de motoristas e ajudantes, seguro, combustível, lubrificação, pneus, entre outros.

Gerenciar estes custos não é uma tarefa fácil e muito menos previsível, desta forma, as empresas vem buscando alternativas para equacionar este problema. Uma das possíveis alternativas é a terceirização das operações logísticas. Segundo Silva, Gandolpho e Carniello (2015), a terceirização de operações logísticas representa uma grande oportunidade em alguns casos e um considerável risco em outros.

Contudo, não analisar devidamente os custos e benefícios dessa terceirização é o maior de todos os riscos. Ballou (2009) demonstra os principais benefícios da terceirização logística:

Custos reduzidos e menores
investimentos de capital;

- Acesso a tecnologias novas e a habilidade gerenciais; Vantagens competitivas como a
crescente penetração no mercado;

- $\quad$ Acesso incrementado à informação útil para o planejamento;

- Redução dos riscos e incerteza.

Ballou (2009) ainda afirma que as principais áreas de todas essas vantagens é a redução potencial dos custos de transporte e a liberação do nível de investimento em áreas não centrais do negócio, seguindo a redução de pessoal. O risco maior para a empresa se encontra em uma possível perda de controle sobre atividades logísticas com prejuízos capazes de anular as vantagens anteriormente relacionadas. Caberá a empresa analisar qual a melhor situação para ela.

\section{TRUCKPAD}

\subsection{O SURGIMENTO DO APLICATIVO}

Carlos Mira, CEO e fundador do aplicativo Truckpad - que mostra a caminhoneiros autônomos onde há oferta de cargas deixou para trás o cargo de PresidenteExecutivo da Mira Transportes (Empresa de sua família) e entrou no mundo das startups utilizando de toda a sua experiência de 30 anos no segmento de transportes. Em entrevista concedida a revista As Maiores do Transporte e as Melhores do Transporte (2015), o empresário conta que a ideia do aplicativo começou a ser construída após uma visita ao Vale do Silício em 2011, onde ouviu de um professor que o smartphone iria mudar o mundo dos negócios. Aquilo ficou na mente de Mira, que relacionou a frase dita pelo professor com Logística, Brasil e como isso poderia integrar embarcadores e caminhoneiros, sem a necessidade de um intermediário, como agenciadores, por exemplo.

Lançado em sua primeira versão simples no ano de 2013 na Google Play após consulta com caminhoneiros e ajuda de amigos especialistas, o aplicativo passou a acumular prêmios e novos adeptos. Em seus primeiros meses de vida, o aplicativo já contava com incríveis 10 mil caminhoneiros que utilizavam a plataforma. Em visita aos Estados Unidos, o aplicativo Truckpad recebeu um importante investimento do grupo LBS/Mobile (Da qual o aplicativo Maplink também faz 
parte), passando a deter $35 \%$ do Truckpad. Ainda segundo a entrevista de Mira a Maiores do Transporte e as Melhores do Transporte (2015), O Truckpad conta com uma base de aproximadamente 300 mil caminhoneiros autônomos e 8 mil empresas conectadas pelo aplicativo.

\subsection{ENTENDO COMO O APLICATIVO FUNCIONA}

Apelidado de "Uber dos caminhoneiros", o aplicativo Truckpad funciona de um modo bem simples, mostrando para o caminhoneiro autônomo onde há oferta de cargas disponíveis, para que ele se programe e evite retornar de viagens com o caminhão vazio (AS MAIORES DO TRANSPORTE E AS MELHORES DO TRANSPORTE, 2015).

Para poder trabalhar com a plataforma do Truckpad, o caminhoneiro deverá inicialmente realizar $\mathrm{O}$ seu cadastro, fornecendo o seu CPF e outros dados da qual são feitas checagens permitidas por lei. Do lado de embarcadores, como uma indústria por exemplo, é necessário o fornecimento de CNPJ, telefone fixo e e-mail corporativo. A partir destas informações, a equipe do Truckpad faz uma checagem completa para verificar se a empresa de fato existe. Dessa forma, percebe-se o quão segura é a plataforma do aplicativo. Podem se cadastrar na plataforma desde caminhoneiros autônomos até varejistas, comerciantes, indústrias e até mesmo agenciadores de carga.

Além de integrar embarcadores e transportadores, 0 aplicativo exibe para 0 caminhoneiro qual será o custo com pedágio, combustível e ainda traça a melhor rota possível. Do lado das empresas, quando realizado o cadastro é perguntado quais tipos de veículo que ela necessita e o principal estado de onde origina suas cargas para outros lugares. Ainda é possível que os caminhoneiros autônomos e as empresas que utilizam a plataforma deixem suas avaliações á respeito do serviço prestado pelo autônomo ou a maneira com que a empresa contratante atuou. O caminhoneiro recebe os documentos do transporte embarcados no aplicativo. É importante ressaltar que quando há uma oferta de carga, o caminhoneiro só poderá fazer uma contraoferta mais alta, evitando assim "leilões de frete" que de certa forma se torna um desserviço para os caminhoneiros, ressalta Mira (AS MAIORES DO TRANSPORTE E AS MELHORES DO TRANSPORTE, 2015).

○ caminhoneiro pode conversar com o contratante através do aplicativo em um chat: ele escreve pelo smartphone e a empresa responde pelo computador, economizando ligações telefônicas. Quando o caminhoneiro chega ao destino e descarrega a mercadoria ele faz um protocolo de entrega pelo celular, tira fotografia do comprovante de entrega e manda a fotografia pelo sistema para o embarcador (AS MAIORES DO TRANSPORTE E AS MELHORES DO TRANSPORTE, 2015).

\section{RESULTADOS E DISCUSSÃO}

Para realizar o transporte de seus produtos, as empresas podem optar por possuir a sua frota própria ou deixar para que um terceiro realize esta operação. Este terceiro pode ser um operador logístico, transportadoras ou até mesmo os TACs (Transportadores Autônomos de Cargas).

Este último - foco do aplicativo - tem sido a saída para muitas empresas, que procuram diminuir custos e evitar responsabilidades com vínculos empregatícios. Para a contratação de um TAC, as empresas precisam gerenciar uma série de questões. Serão descritos os processos e custos que o aplicativo pode otimizar:

- Negociação e localização de autônomos: Para realizar a contratação de um TAC, as empresas precisam procurar pelos autônomos e realizar a negociação (muitas vezes por telefone). Com a utilização do aplicativo, essa burocracia seria facilmente eliminada, visto que para procurar por autônomos, basta a empresa inserir no aplicativo a carga que deseja ser transportada, seu destino e outras especificações tangentes. Desse modo, tempo seria ganho e ainda haveria uma economia em relação as ligações telefônicas;

- $\quad$ Contratação e preço do frete: Com a contratação direta do autônomo, sem a necessidade de intermediários, o preço do frete tende a ser menor. De acordo com Mira, em entrevista realizada a revista As Maiores do Transporte (2015), quando empresas que necessitam intensamente do transporte contratam diretamente um transportador autônomo, ocorre uma 
economia de $50 \%$ no valor do frete. Além, é claro, do processo ser muito mais rápido, visto que não há intermediários, caracterizando uma contratação diretamente com o autônomo;

- Burocracia documental: O envio e recebimento de documentos de transporte é facilmente realizado na plataforma. O sistema permite o fluxo dos documentos entre os TACs e as empresas. Ainda, quando a entrega é realizada, o sistema solicita para que o transportador envie o protocolo de entrega, fotos dos documentos e das mercadorias.

Dessa forma, é possível perceber o quanto - aplicativo pode ser eficiente, tornando cadeias de suprimentos mais dinâmicas.

Após conhecidas as aplicações do Truckpad, é interessante conhecer também como o aplicativo mede a eficiência dos seus serviços. Como ele conhece a eficácia de sua plataforma e qual o principal Key Performance Indicator (KPI) utilizado?

Depois de consulta realizada com o Truckpad, foi possível descobrir que o melhor KPI utilizado para a medição do seu nível de serviço é o número de fretes fechados na plataforma. É com esse número que o aplicativo compreende que conseguiu satisfazer tanto o transportador autônomo quanto a empresa contratante. Ainda, outra métrica empregada é o número percentual de usuários que voltaram a usar a plataforma, sendo esta métrica atualizada todos os meses. Se um usuário acessou o Truckpad, fechou um frete e depois voltou para realizar mais negócios, significa que foi entregue o valor que o usuário buscava e que o aplicativo cumpriu o seu prometido.

\section{CONSIDERAÇÕES FINAIS}

Com base no trabalho que foi realizado, conclui-se que o conceito colaborativo é uma realidade cada vez mais crescente no contexto da logística brasileira. Analisando apenas a aplicação do Truckpad, foi possível perceber um número de 8 mil empresas que utilizam ativamente a plataforma e mais de 300 mil transportadores autônomos. Esse número de usuários cresce ano após ano, mostrando que empresas estão se atentando para novos conceitos de gestão.

Ainda, foi possivel perceber que o aplicativo Truckpad pode ser uma ferramenta capaz de tornar as vidas de empresas e transportadores autônomos práticas. A praticidade que 0 aplicativo oferece diz respeito principalmente a diminuição de etapas no processo de contratação de um frete, a qual é conseguida através da economia de tempo com ligações telefônicas e fluxo de documentos. A constatação a partir da análise do aplicativo, permitiu verificar que a plataforma é capaz de agilizar os processos, diminuir custos e eliminar barreiras burocráticas tangentes a contratação de um frete.

Este estudo tratou-se de uma análise superficial para a apresentação dos benefícios que a utilização do aplicativo pode ocasionar para as empresas. Para a implantação do uso desta aplicação, é necessária uma análise mais profunda levando em conta aspectos de viabilidade, já que são necessários para o seu uso a necessidade de um treinamento para aquele que irá realizar as contratações de autônomos na plataforma. Para futuros trabalhos referentes ao tema, sugere-se uma análise do aplicativo Truckpad sob a ótica do transportador

autônomo.

\section{REFERÊNCIAS}

[1]. AS MAIORES DO TRANSPORTE E AS MELHORES DO TRANSPORTE. São Paulo, 2015. Disponível em: <www.drive.google.com/file/d/OBBWC6fUoRuCVFFMR2p1a213QnM/view>. Acesso em 20 Outubro 2017. 17h40.

[2]. BALLOU, Ronald H. Gerenciamento da Cadeia de Suprimentos: Logística Empresarial. $5^{\underline{a}}$ ed. Bookman Editora, 2009.

[3]. BARROS, Ana Cirne Paes de. Uber: O Consumo Colaborativo e as Lógicas do
Mercado. São Paulo: Congresso Internacional Comunicação e Consumo, 2015. Disponível em: $<\quad$ http://www.anaiscomunicon2015.espm.br/GTs/GT5/24_GT5_BARRO S.pdf>. Acesso em: 4 Novembro 2017. $20 \mathrm{~h} 40$.

[4]. BOTTER, Rui Carlos; TACLA, Douglas; HINO, Celso Mitsuo. Estudo e aplicação de transporte colaborativo para cargas de grande volume. Pesquisa Operacional, v. 26, n. 1, p. 25-49, 2006. Disponível em: 
[5]. <http://www.scielo.br/pdf/pope/v26n1/2947 3.pdf >. Acesso em: 4 Novembro 2017. 21 h00.

[6]. BROWNING, B.; WHITE, A. Collaborative Transportation Management - A Proposal. EUA, 2001.

CASTIGLIONI, José Antonio de Mattos; NASCIMENTO, Francisco Carlos do.

[8]. Custos de processos logísticos. Érica, São Paulo, p. 5-136, 2014

[9]. FIGUEIREDO, R.; EIRAS, J. Transporte colaborativo: conceituação, benefícios e práticas (parte 1). ILOS, Instituto de Logística e Supply Chain, 2007. Disponível em: <http://xa.yimg.com/kq/groups/24690439/10766158 98/name/transporte_colaborativo_parte_1\%5B1\%5D .pdf>. Acesso em 5 Novembro 2017. 21h05.

[10]. FREITAS, WR de S.; JABBOUR, CJC. O estudo de caso (s) como estratégia de pesquisa qualitativa: fundamentos, roteiro de aplicação e pressupostos de excelência. XXX Encontro Nacional de Engenharia de Produção, São Carlos, $2010 . \quad$ Disponível em:

[11]. <http://www.abepro.org.br/biblioteca/eneg ep2010_tn_sto_122_790_15342.pdf>. Acesso em: 26 Novembro 2017. 21h30.

[12]. FUNDACÃO NACIONAL DA QUALIDADE - FNQ. Economia Colaborativa. São Paulo: FNQ, 2016. GANSKY, Lisa. Mesh: porque o futuro dos negócios é compartilhar. Alta Books Editora, 2011.

[13]. ILOS, Instituto de Logística e Supply Chain. Panorama ILOS, Custos Logísticos no Brasil. Rio de Janeiro, 2014. Disponível em: <http://www.ilos.com.br/web/custos- logisticos-nobrasil/>. Acesso em: 7 Novembro 2017. 21h11.

[14]. KAUFMAN, Dora; ROZA, Erick. Empresas e consumidores em rede: um estudo das práticas colaborativas no Brasil. São Paulo: Annablume, 2013

[15]. KOTLER, Philip; KARTAJAYA, Hiermawan; SETIWAAN, Iwan. Marketing 3.0: as forças que estão definindo o novo marketing centrado no ser humano. Elsevier, 2010.

[16]. MARIN, Evandro. R. Economia Compartilhada e o Mercado Segurador. Revista Cadernos de Seguro. Escola Nacional de Seguros, Julho, 2016

[17]. MARKET ANALYSIS. O consumo colaborativo e consumidor brasileiro. Florianópolis, 2015. Disponível em: <http://marketanalysis.com.br/wpcontent/uploads/2017/04/2015-Market-Analysis-Oconsumo-colaborativo-e-o consumidorbrasileiro.pdf>. Acesso em: 6 Novembro 2017. $20 h 42$.

[18]. NICOLINI, M. A. S. Logística Colaborativa - Como a evolução dos conceitos contribui para a otimização e integração dos processos logísticos. Universidade Candido Mendes. Rio de Janeiro, 2011. Disponível em: <http://www.avm.edu.br/docpdf/monografias_public adas/k217399.pdf>. Acesso em 6 novembro 2017. $21 \mathrm{~h} 41$.

[19]. PINTO, Jefferson dos santos; OLIVEIRA, Arlisson da Costa; COSTA, Herivan Sanches; VILHENA, Joecy Pereira. Collaborative Transportation Management (CTM): Seus Benefícios e Atuais Práticas. XXXV Encontro Nacional de Engenharia de Produção. Fortaleza, 2015. Disponível em: < http://www.abepro.org.br/biblioteca/TN_STO_206_2 22_28234.pdf>. Acesso em 12 Fevereiro 2018. $21 \mathrm{~h} 21$.

[20]. SECRETARIA DE ESTADO DOS TRANSPORTES DE SÃO PAULO. Pesquisa de Origem e Destino do Transporte Rodoviário e Aéreo do Estado de São Paulo. São Paulo, 2006.

[21]. SILVA, Juliana Lopes Da; GANDOLPHO, Marcelo Renato; CARNIELLO, Monica Franchi. Comparação dos custos entre frota própria e terceirizada em uma transportadora do Vale do Paraíba-SP. Revista de Ciências Gerenciais, v. 16, n. 24, 2015. Disponível em:

http://www.pgsskroton.com.br/seer/index.php/rcger/ article/view/1949/1853>. Acesso em 12 Fevereiro 2018. $21 \mathrm{~h} 41$

[22]. SILVA, V. M. D.; ZAGO, C. A.; ABREU, L. F.; COELHO, A. S.; GONCALVES, M. B. La influencia de la gestión del transporte colaborativo para la eficiencia de la cadena de suministros. Anales del XIV International Conference on Industrial Engineering and Operations Management (ICIEOM), Salvador, 2009. Disponível em: < http://www.abepro.org.br/biblioteca/enegep2009_TI _ST_091_617_13692.pdf >. Acesso em 13 Fevereiro 2018. 14h21.

[23]. SILVA, Vanina Macowski Durski; ZAGO, Camila Avozani; COELHO, Antônio Sérgio. "COLLABORATIVE TRANSPORTATION MANAGEMENT"(CTM): UM NOVO CONCEITO LOGÍSTICO PARA AUMENTAR A EFICIÊNCIA DA CADEIA DE

[24]. SUPRIMENTOS.

Perspectivas Contemporâneas, v. 4, n. 2. Campo Mourão, 2009. Disponível em: <http://revista.grupointegrado.br/revista/index.php/ perspectivascontemporaneas/articl e/view/584/287>. Acesso em 13 Fevereiro 2018. $21 \mathrm{~h} 25$.

[25]. SILVA, Vanina Macowski Durski; PRADO, Jacqueline Ribeiro; BARROS, Thayse Dobis. Logística colaborativa: um Estudo de Caso no Setor de Armazenagem e Logística. Simpósio de Excelência em Gestão e Tecnologia, 2013.

em: 
<http://www.aedb.br/seget/arquivos/artigos 13/2021 8131. pdf >. Acesso em 14 Fevereiro 2018. $16 \mathrm{~h} 47$.

[26]. SILVEIRA, Alexandre Borba Da. Economia Colaborativa: reflexões a partir da literatura. Desenvolve Revista de Gestão do Unilasalle, Canoas, v. 6, n. 2, 2017. Disponível em: $<$ http://revistas.unilasalle.edu.br/index.php/desenvol ve/article/view/3378/0>. Acesso em 14 Fevereiro 2018. $21 \mathrm{~h} 56$. 


\section{Capítulo 12}

\section{CONTRIBUIÇÕES DOS SISTEMAS LEAN PARA A CRIACÃO DE PROCESSOS DE UM EXPERIMENTAL DE DESIGN}

\section{Edney Eboli dos Santos}

\section{Gabriel José Barbosa}

Marília Macorin de Azevedo

Antonio César Galhardi

\section{Daiane Belchior}

\section{Atila Brito.}

Resumo: O objetivo deste artigo é identificar as contribuições da aplicação de conceitos dos sistemas Lean como recomendações para a criação de fluxos de processos em um estúdio experimental de design a partir da metodologia de produção enxuta aplicada a serviços. Este método é denominado Lean Services. O tema apresenta relevância, uma vez que se busca cada vez mais otimizar processos para a condução de serviços com foco em redução de custos, tempo e outras possíveis perdas. A metodologia adotada foi de análise qualitativa, utilizando pesquisa-ação com base em entrevistas com os responsáveis do estúdio, análise bibliográfica e análise documental. A partir do material coletado, se entendeu o cenário e os fluxos de processos do estúdio. A análise dos dados permitiu identificar potenciais melhorias no fluxo de processos a partir da contribuição dos sistemas Lean. A análise concluiu que a utilização dos sistemas Lean contribui com a eficácia no desenvolvimento de projetos acadêmicos num estúdio experimental de design.

Palavras-chave: Lean, Lean Services, Lean Office, Estúdio Experimental, Design. 


\section{INTRODUÇÃO}

A criação de um Estúdio Experimental de Design para cursos de graduação em Design de Produto e Design Gráfico atende a uma recomendação das diretrizes curriculares do MEC.

O objeto de estudo deste artigo é um Estúdio experimental de Design em fase de conceituação, que irá funcionar como um escritório de projetos acadêmicos em atividades extracurriculares optativas por alunos dos cursos de Bacharelado em Design de Produto, Bacharelado em Design Gráfico e Tecnologia em Design Gráfico oferecidos por um Centro Universitário privado cujo campus dos referidos cursos localiza-se no bairro da Vila Mariana, cidade de São Paulo.

O projeto do Estúdio Experimental de Design conta com um regulamento que foi criado por professores da instituição, com o apoio e acompanhamento da coordenação pedagógica dos cursos de Design e da diretoria da Escola de Educação, Comunicação, Artes, Design e Moda.

O sistema Lean foi criado com o objetivo de eliminar desperdícios e aumentar o rendimento econômico das empresas. O Lean services é um desdobramento deste sistema que tem por objetivo o ganho de qualidade e eficiência pela aplicação de conceitos do pensamento Lean no setor de serviços, área em que se enquadra um Estúdio experimental de Design.

A partir do que se verificou na utilização dos métodos Lean no setor de serviços, este estudo visa responder ao questionamento: Há contribuição do sistema Lean na criação de fluxos de processos mais eficazes para o desenvolvimento de Projetos acadêmicos em um Estúdio Experimental de Design?

Para responder a esta questão de pesquisa, foi definido como objetivo geral da pesquisa a identificação das contribuições na aplicação de conceitos dos sistemas Lean como recomendações para a criação de fluxos de processos em um estúdio experimental de design. Como objetivos específicos, busca-se entender os fluxos de processos a serem utilizados no desenvolvimento de projetos acadêmicos de um estúdio experimental de design, identificar em quais etapas ou atividades dos processos é possível aplicar os conceitos dos sistemas Lean de forma a aumentar sua eficácia, projetar novos fluxos de processos para desenvolvimento de projetos acadêmicos de um estúdio experimental de design e identificar as contribuições dos sistemas Lean na criação de fluxos de processos eficazes para este estúdio.

\section{FUNDAMENTAÇÃO TEÓRICA}

\subsection{SISTEMA LEAN}

O sistema de manufatura enxuta foi desenvolvido pelo executivo da Toyota, Taiichi Ohno, na tentativa de encontrar uma solução para o colapso das vendas que fez com que houvesse uma demissão em massa na empresa (WOMACK; JONES, 2004). Este colapso mostrou que o sistema de produção em massa não funcionaria no Japão como funcionava na fábrica da Ford, em Detroit, o que objetivou a busca por um modelo que fizesse a indústria automobilística japonesa ser competitiva ante os concorrentes americanos e europeus. Segundo Womack e Jones (2004), este modelo de manufatura enxuta recebeu o nome de Toyota Production System (TPS) e somente nos anos 90 foi identificado como Lean.

O modelo propunha como objetivo a eliminação de perdas, que otimizaria os processos, aumentando o rendimento econômico. De acordo com Womack e Jones (2003), os princípios do modelo são: especificação de valor, mapeamento do fluxo de valor, otimização de fluxo, sistema de produção "pull' (produção direcionada pela demanda) e perfeição ou melhoria contínua.

Segundo Ohno (1997), os tipos de perdas identificadas foram:

- Transporte: Movimentar produtos que não são requisitados para o processo;

- Inventário: Todos os componentes, trabalhos em processo e produto acabado não estão sendo processados;

- Movimento: Pessoas ou equipamentos sendo movimentados mais do que o necessitado;

- $\quad$ Espera: Espera pelo próximo passo da produção;

- $\quad$ Superprodução: Produção à frente da demanda;

- Superprocessamento: Resultado de uma ferramenta pobre ou design de produção criando atividades; 
- Defeitos: esforço envolvido na inspeção e na reparação de defeitos.

\subsection{LEAN SERVICE}

O setor de serviços tem grande relevância dentro da cadeia econômica em qualquer país do mundo (ASIF et al., 2010) e, por consequência, as empresas que atuam no setor buscam cada vez mais otimizar seus processos e fluxos de trabalho para aumentarem os ganhos ou reduzirem desperdícios de tempo, mão-de-obra, recursos entre outros. Com isto, a utilização de técnicas ou ferramentas que possam contribuir para o sucesso desta otimização se torna necessária e, analisando a utilização dos sistemas Lean na manufatura, cada vez mais se percebe a oportunidade de aplicação destes no setor de serviços.

A utilização da metodologia Lean na manufatura trouxe mudanças para o setor pela filosofia de reduzir desperdícios, gerando assim ganhos pela economia de diversos aspectos dentro dos processos. A ideia de empregar esta filosofia também no setor de serviços gerou estudos que contribuíram com a adaptação dos conceitos que eram utilizados na manufatura para a realidade do setor de serviços.
O conceito central em Lean Services é remover as perdas nos processos de serviços. Womack e Jones (2003) classificaram as tarefas em três tipos:

- Aquelas que adicionam valor (transformando diretamente o produto na forma desejada pelo usuário);

- $\quad$ Aquelas que não agregam valor, mas são necessárias com métodos de produção atuais;

- $\quad$ Aquelas que não agregam valor e são desnecessárias.

Os resíduos nos serviços podem ser tangíveis e intangíveis (ASIF et al., 2010), e a intangibilidade dos resíduos dificulta a gestão. Por exemplo, o excesso de estoque de produtos físicos é considerado um desperdício nos processos de fabricação. No entanto, os conceitos convencionais de estoque e redução de estoque não se aplicam prontamente aos processos de serviços. Portanto, os tipos de resíduos e sua gestão são fundamentalmente diferentes nos serviços.

Segundo Bicheno e Holweg (2009), o comparativo entre as perdas identificadas na manufatura e as perdas identificadas em serviços está demonstrado no Quadro1.

QUADRO 1 - Comparativo entre desperdícios em manufatura e em serviços

\begin{tabular}{|l|l|}
\hline Desperdícios em manufatura & \multicolumn{1}{c|}{ Desperdícios em serviços } \\
\hline Superprodução & Duplicação de processos, dados etc. \\
\hline Transporte & Oportunidade perdida de reter ou ganhar consumidores \\
\hline Inventário & Inventário incorreto \\
\hline Movimento & Movimento desnecessário \\
\hline Defeitos & Erros nas transações \\
\hline Superprocessamento & Comunicação não clara \\
\hline Espera & Atraso para a entrega do serviço \\
\hline \multicolumn{2}{|c|}{ Fonte: os autores, adaptado de Bicheno e Holweg (2009) } \\
\hline
\end{tabular}

Para os princípios do Lean Services, Womack e Jones (2003) indicaram o seguinte:

- Resolva completamente o problema do cliente garantindo que todos os bens e serviços funcionem e trabalhem juntos;

- $\quad$ Não desperdice o tempo do cliente;

- Forneça exatamente o que o cliente deseja;
- Forneça o que é desejado exatamente onde é desejado;

- Forneça o que é desejado, onde é desejado, exatamente quando é desejado;

- Agregue soluções continuamente para reduzir o tempo e o aborrecimento do cliente. 


\subsection{LEAN OFFICE}

O Lean Institute com sede no Brasil define o Lean Thinking (Pensamento Lean) como uma ferramenta que busca a maximização de valor dos processos pela contínua eliminação de desperdícios. Desta forma, define que o cliente é quem define o que é valor, e não a empresa. Defende um mapeamento de fluxo de valor categorizando os processos em três níveis: os processos que geram valor, os processos que não geram valor, mas são importantes (e devem ser mantidos), e os processos que não geram valor e devem ser eliminados. O Lean Institute recomenda a criação de fluxos contínuos para se obter maior fluidez nos processos.

O Lean Office avançou na década de 1970 para o setor de serviços na economia mundial com foco na qualidade, eficiência e produtividade dos serviços.

Nas empresas, em que diversos processos são integrados, a aplicação do Lean Office é recomendada para se eliminar desperdícios e acelerar a velocidade dos processos.

Das ferramentas do Lean, ao menos três delas podem ser aplicadas para análise e verificação de aplicação de contribuições para os processos do Estúdio Experimental de Design:

- VSM (Value Stream Mapping) ferramenta utilizada para visualização dos processos, fluxos de materiais e de informações. Com esta ferramenta podemos caracterizar o estado atual do fluxo, definindo possíveis problemas e causas para se desenhar o estado futuro desejado do fluxo de valor. Esta ferramenta possibilita uma análise do fluxo da informação identificando desperdícios.

- $\quad$ Fluxo puxado (Pull) - ferramenta para avaliação dos processos pela perspectiva de um fluxo puxado das informações com o objetivo de organizar o trabalho para que o fluxo de informações aconteça sem paradas ou estoques, evitando concentração de trabalho ou sobreposição de atividades.

- FIFO (First-In First-Out) - método que define que todas as informações devem ser processadas seguindo sua ordem de entrada no fluxo.

A análise do fluxo de processos do Estúdio Experimental de Design utilizará como referência os desperdícios encontrados em ambientes administrativos citados por Lareau
(2002), que catalogou trinta desperdícios administrativos dos quais seis são aplicáveis ao objeto de estudo deste artigo.

\section{A PESQUISA}

Esta pesquisa foi aplicada com objetivo exploratório de abordagem qualitativa utilizando como procedimentos os métodos análise bibliográfica e pesquisa-ação a partir de entrevistas, observação participante, questionário e análise documental.

Mello et al. (2012) definem que, na pesquisaação, o pesquisador, utilizando a observação participante, interfere no objeto de estudo de forma cooperativa com os participantes da ação para resolver um problema e contribuir para a base do conhecimento.

Como procedimento para a pesquisa, foi realizada uma pesquisa bibliográfica sobre a utilização do Lean em serviços e escritórios de projetos, além de análise documental do regulamento que rege o estúdio alvo da pesquisa. $\mathrm{Na}$ sequência, foram aplicadas entrevistas de contextualização com os professores idealizadores do estúdio para entendimento dos fluxos de processos propostos. A partir disto, fez-se uma análise dos processos e levantamento das oportunidades de contribuição do Lean nos processos apresentados, concluindo com a reformulação dos processos a partir das ferramentas Lean.

A partir de uma análise documental do regulamento do Estúdio Experimental de Design e de entrevistas semiestruturadas aplicadas aos professores idealizadores foi possível conhecer a missão, os objetivos, valores, métodos, frentes de atuação, estrutura e fluxos de trabalho, idealizados para iniciar a implementação dos serviços de atendimento e orientação a projetos de alunos a partir do primeiro semestre letivo de 2018.

Os procedimentos utilizados nesta pesquisa (entrevistas, observação participante, questionários e análise documental) justificam-se pelo fato de um dos autores deste artigo atuar como docente na orientação de projetos acadêmicos de design junto ao grupo de professores idealizadores do Estúdio Experimental, o que permitiu a aplicação do método pesquisa-ação.

A análise documental possibilitou 0 entendimento do propósito do Estúdio, que visa a criação de um laboratório de projetos 
que complemente a formação dos alunos dos cursos de Design a partir da vivência prática pelo desenvolvimento de projetos com base nos conceitos teóricos discutidos em sala de aula. Esta prática extracurricular colabora na qualificação profissional do aluno, que vivencia situações reais da rotina profissional. O documento esclarece também que a idealização do Estúdio Experimental de Design surgiu da necessidade percebida de transição da vida acadêmica ao ambiente profissional. Desta forma, por meio da vivência em projetos interdisciplinares aplicados, o estúdio oferecerá a oportunidade de desenvolver atividades de transição que oportunizam o debate não só de questões relativas ao campo do saber, mas também às práxis diárias do futuro profissional, postura frente a desafios, capitalização de portfólio, relacionamento interpessoal, entre outras competências solicitadas pelo mercado de trabalho que complementarão sua formação profissional.

\section{COLETA DOS DADOS}

A partir da filosofia Lean, foi analisado o fluxo de processos proposto pelos professores idealizadores do estúdio Experimental de Design com o objetivo de identificar possíveis contribuições da aplicação dos conceitos Lean e apontar recomendações para a criação de um fluxo de processos mais enxuto, eliminando potenciais perdas e desperdícios de tempo, aumentando a eficácia dos serviços prestados.

A partir de um levantamento feito por Gronovicz et al. (2013) sobre os principais desperdícios existentes em um escritório de projetos, fez-se uma correlação destes dados com as atividades inerentes ao Estúdio experimental de design, conforme mostra o Quadro 2.

QUADRO 2 - Desperdícios em ambientes administrativos e sua relação com o Estúdio Experimental de Design

\begin{tabular}{|c|c|c|}
\hline Desperdício & Definição & Relação com o objeto de estudo \\
\hline $\begin{array}{l}\text { Alinhamento de } \\
\text { objetivos }\end{array}$ & $\begin{array}{l}\text { Relacionado à estratégia gasta por pessoas } \\
\text { trabalhando com objetivos mal-entendidos e o } \\
\text { esforço necessário para corrigir o problema e } \\
\text { reproduzir o resultado esperado. }\end{array}$ & $\begin{array}{l}\text { Reuniões presenciais são importantes para dirimir dúvidas em } \\
\text { ambientes de projetos de design devido à natureza da informação } \\
\text { discutida (desenhos, sketches, croquis, ilustrações) }\end{array}$ \\
\hline Espera & $\begin{array}{l}\text { Recurso perdido enquanto pessoas esperam por } \\
\text { informações, reuniões, assinaturas, retorno de uma } \\
\text { ligação e assim por diante. }\end{array}$ & $\begin{array}{l}\text { Relação entre o agendamento prévio das reuniões presenciais } \\
\text { com o tempo de desenvolvimento de entregáveis do projeto pelo } \\
\text { aluno }\end{array}$ \\
\hline Agenda & $\begin{array}{l}\text { Má utilização de horários e agendas dos } \\
\text { participantes }\end{array}$ & Necessidade de agendamentos e de reuniões presenciais \\
\hline $\begin{array}{c}\text { Revisões } \\
\text { desnecessárias }\end{array}$ & Esforço usado para inspeções e retrabalhos & $\begin{array}{l}\text { Análise do fluxo de processos relacionados às necessidades de } \\
\text { revisões de projeto e avaliações }\end{array}$ \\
\hline $\begin{array}{l}\text { Falta de } \\
\text { integração }\end{array}$ & $\begin{array}{l}\text { Esforço necessário para transferir informações } \\
\text { dentro de uma organização que não estão } \\
\text { completamente integradas à cadeia de processos } \\
\text { utilizados. }\end{array}$ & $\begin{array}{l}\text { Análise de potencial melhoria de integração das informações entre } \\
\text { alunos e professores }\end{array}$ \\
\hline Transporte & $\begin{array}{l}\text { Todo o transporte de materiais e informações, } \\
\text { exceto aqueles utilizados para entregar produtos e } \\
\text { serviços a clientes. }\end{array}$ & $\begin{array}{l}\text { Análise de como serão feitas as entregas de desenhos, memoriais } \\
\text { e relatórios do projeto }\end{array}$ \\
\hline
\end{tabular}

Fonte: os autores, adaptado de Gronovicz et al. (2013)

A partir de entrevistas semiestruturadas que ocorreram entre os dias 26/10/17 e 31/10/17 com os dois professores idealizadores do Estúdio, pôde-se conhecer em detalhes as fases necessárias para a implementação dos serviços de atendimento e orientação de projetos, considerando: fase de divulgação do Estúdio aos alunos, abertura das inscrições de candidatos, seleção de alunos e projetos, planejamento dos projetos, conceituação, desenvolvimento, revisões, avaliações, formas de registro, conclusão e apresentação.

Por meio de reuniões presenciais, ligações telefônicas e trocas de informações por emails e aplicativos de smartphones entre os dias 14/09/17 e 31/10/17, com a participação dos pesquisadores e dos professores idealizadores do estúdio, foi possível o levantamento dos dados que contribuíram para a cocriação de um fluxo de processos preliminar necessário à implementação do estúdio. Esse esboço preliminar do fluxo de 
processos foi validado pelos professores idealizadores considerando apenas as necessidades expostas e a experiência desses professores como orientadores de projetos acadêmicos de design, sem qualquer interferência do pensamento Lean. A análise desse fluxo preliminar possibilitou aos autores entenderem os processos inerentes ao desenvolvimento de projetos acadêmicos de um estúdio experimental de design.

Os fluxos de processos preliminares desenhados preliminarmente pelos idealizadores do estúdio, sem a aplicação dos conceitos Lean, são apresentados nos quadros 3 a 6 .

Os quadros apresentam: os fluxos dos processos; uma descrição simplificada de cada atividade; e uma legenda que identifica os envolvidos em cada uma das atividades dos processos a partir da nomenclatura $\mathrm{A} / \mathrm{B} / \mathrm{C} / \mathrm{D} / \mathrm{E}$

A - Secretaria: corresponde ao canal formal de relacionamento entre $o$ aluno $e$ a instituição, responsável por protocolar documentos, atender às diversas solicitações burocráticas dos alunos e dirimir dúvidas quanto a processos internos da instituição.

B - Aluno: no âmbito de nosso estudo, corresponde ao aluno devidamente matriculado em qualquer um dos cursos de bacharelado ou tecnológico em Design que, por iniciativa própria se candidata a participar como orientando dos professores no Estúdio
Experimental de Design com o objetivo de realizar projetos de design optativos ao programa oficial curricular, a fim de desenvolver competências profissionais a partir das vivências de um projeto aplicado real, seja solicitado por um cliente externo (exemplos: concursos de design ou projetos para Organizações não governamentais) ou sugerido pelos professores para formação e incremento do portfólio do aluno.

C - Professor Estúdio Experimental: corresponde ao professor que dará suporte ao aluno como orientador do projeto de design, contribuindo para a tomada de decisões de projeto, escolhas de alternativas, discutindo propostas e avaliando o aluno em cada etapa do projeto.

D - Coordenação do Curso: responsável por acompanhar e validar as atividades do estúdio experimental, garantindo que as atividades complementem os componentes curriculares de forma a agregar valor à formação do aluno.

E - Cliente Externo: demandante de um projeto de design, seja uma ONG (Organização Não Governamental), um concurso de design ou ainda áreas internas da instituição.

O quadro 3 refere-se ao Processo de Inscrição e Seleção de discentes, primeiro fluxo de atividades previsto para viabilizar as atividades do Estúdio. 
QUADRO 3 - Processo de Inscrição e Seleção de discentes

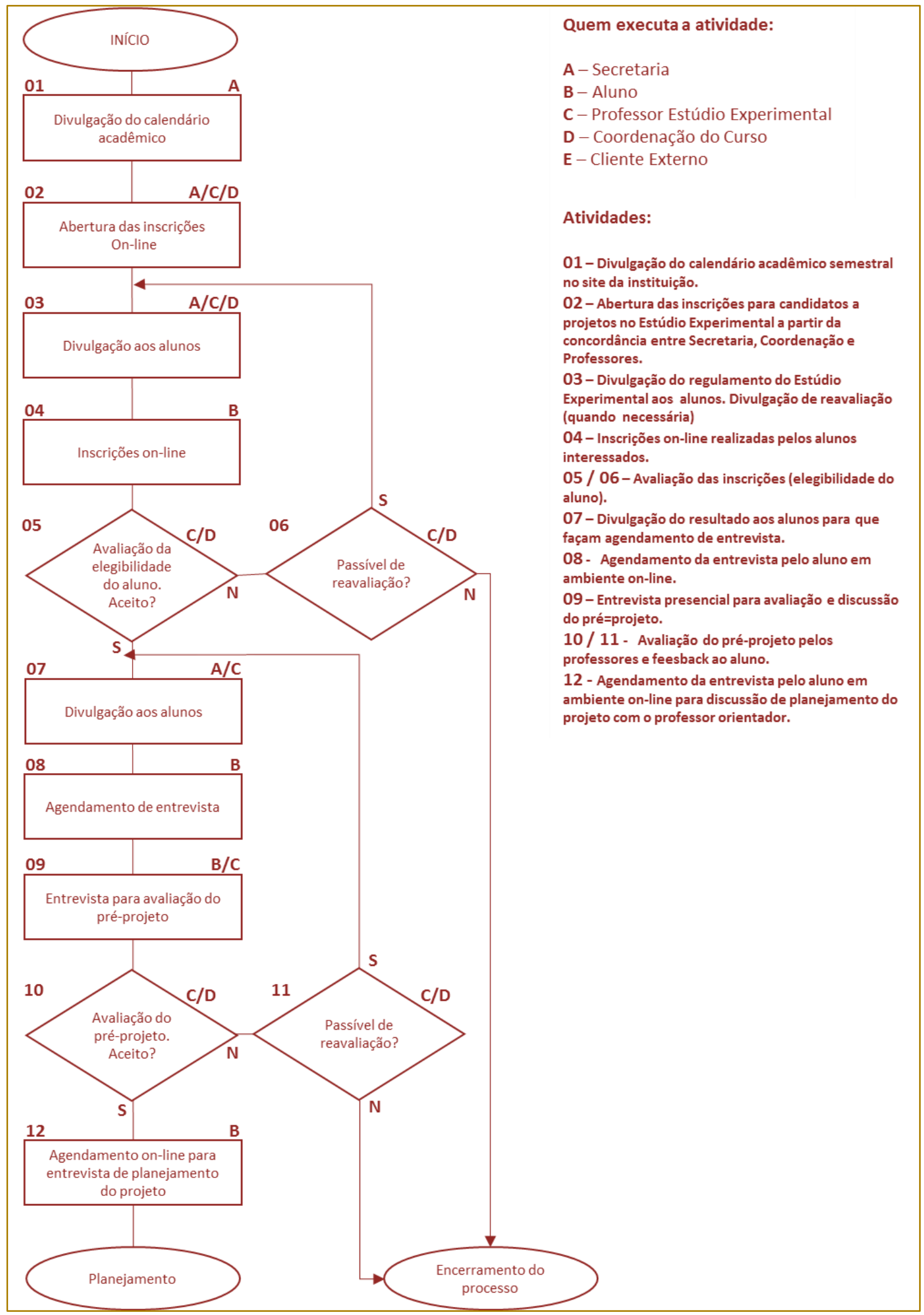

Fonte: Regulamento do Estúdio Experimental de Design (2017)

Este quadro apresenta o fluxo de como será feita a divulgação dos serviços do estúdio experimental, as inscrições e a seleção dos alunos. Sua importância está relacionada à garantia da qualidade dos serviços prestados no que se refere ao planejamento da 
capacidade de atendimento (número de projetos inscritos versus da capacidade de atendimento semestral).

O quadro 4 apresenta o Processo de Planejamento do Projeto e detalha as primeiras atividades desenvolvidas entre os professores orientadores e alunos com o objetivo de desenvolver o planejamento do projeto e delinear o briefing que norteará o desenvolvimento.

QUADRO 4 - Processo de Planejamento do Projeto

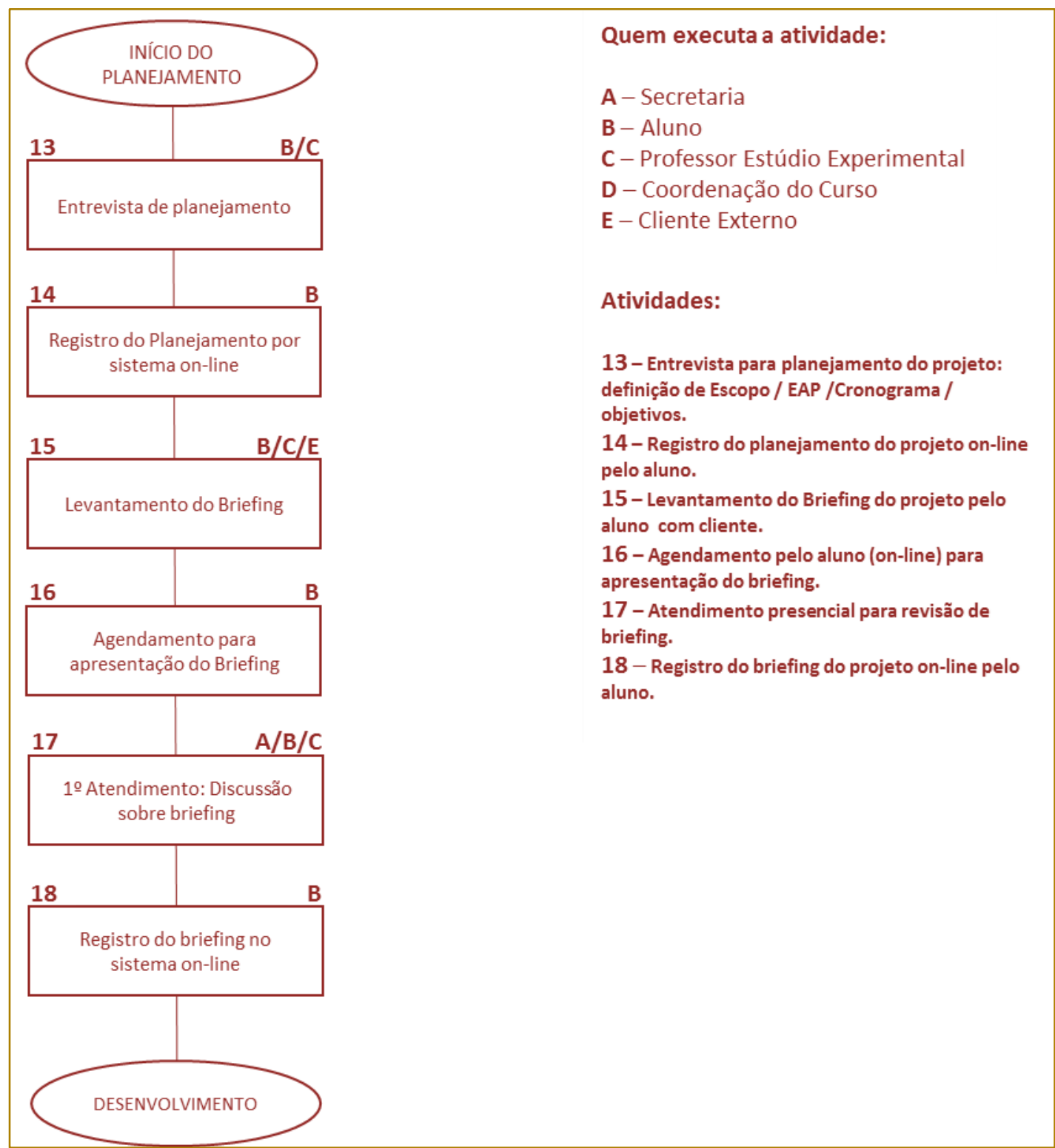

Fonte: Regulamento do Estúdio Experimental de Design (2017)

A importância deste fluxo está relacionada à definição clara dos objetivos do projeto, elaboração e registro dos requerimentos e premissas.

O quadro 5 traz o processo relativo à Conceituação de Design, ou seja, das atividades relacionadas às pesquisas que levarão ao desenvolvimento de propostas que atendam à problemática definida pela síntese das pesquisas. 
QUADRO 5 - Processo de Conceituação de Design

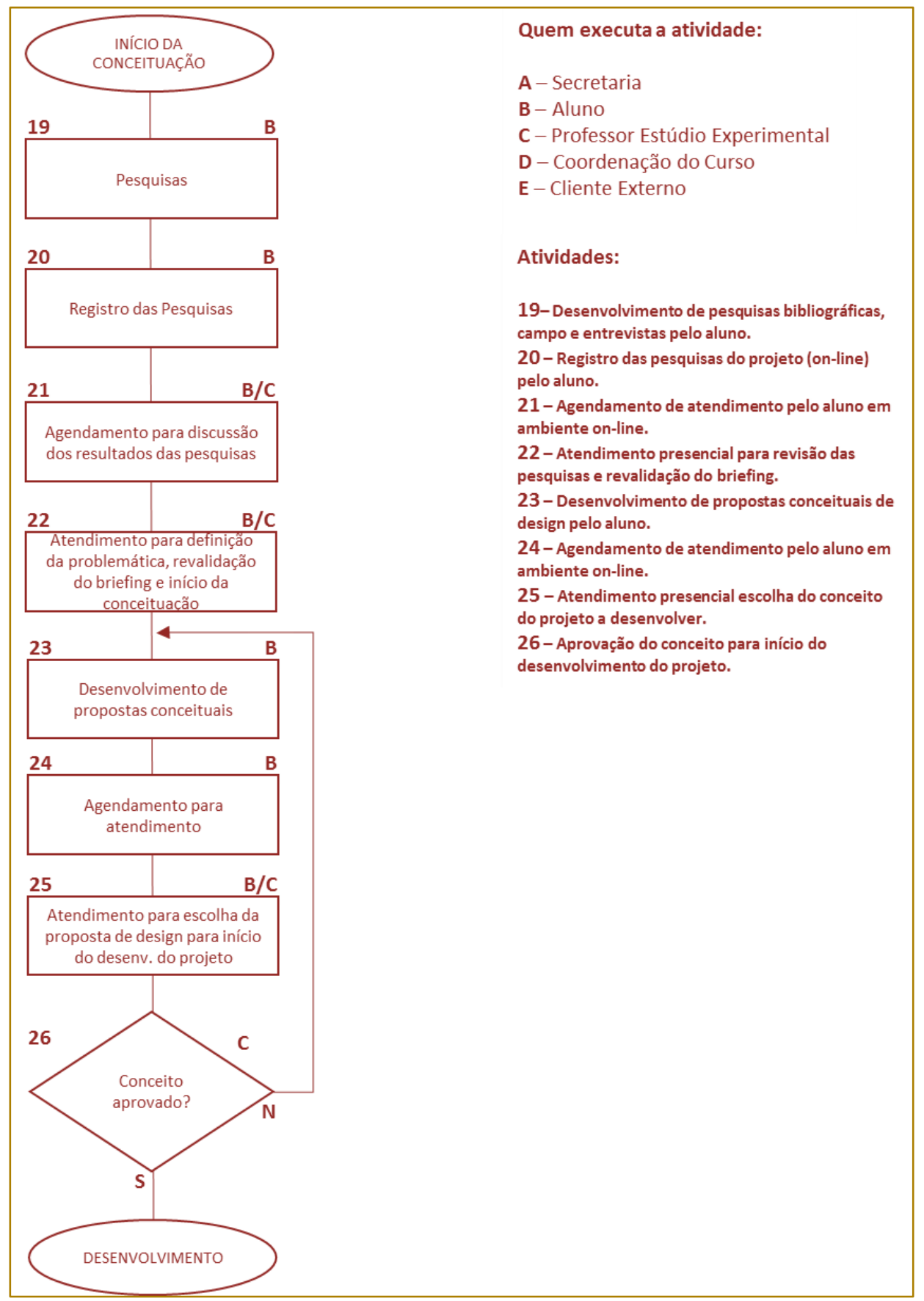

Fonte: Regulamento do Estúdio Experimental de Design (2017)

A importância deste fluxo está relacionada à definição clara da problemática a ser solucionada no projeto e ao registro documental do conceito de design a ser desenvolvido.
O quadro 6 demonstra o Processo de Desenvolvimento do Projeto e Apresentação. 
QUADRO 6 - Processo de Desenvolvimento do Projeto e Apresentação

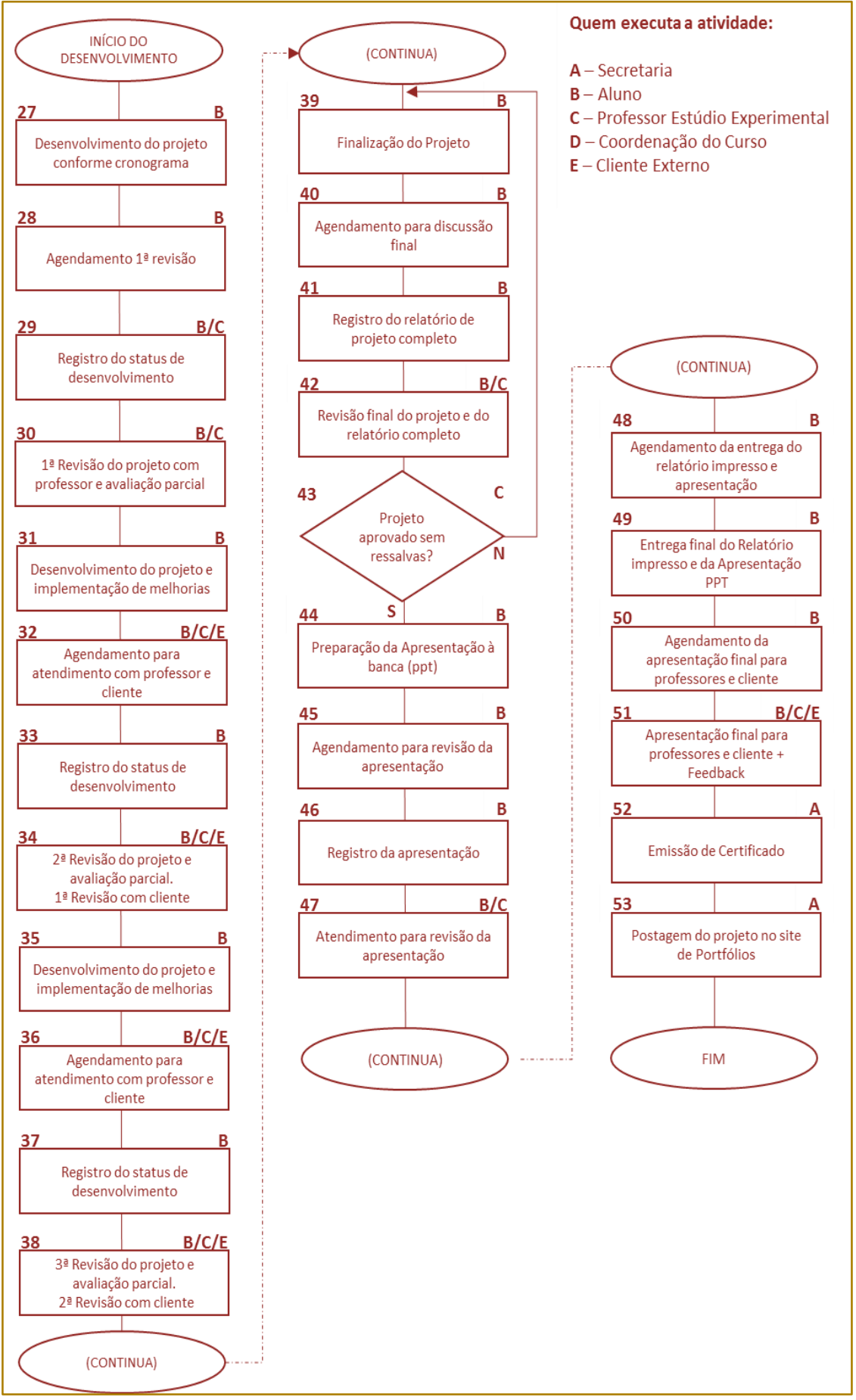

Fonte: Regulamento do Estúdio Experimental de Design (2017) 
QUADRO 6 - Processo de Desenvolvimento do Projeto e Apresentação (continuação)

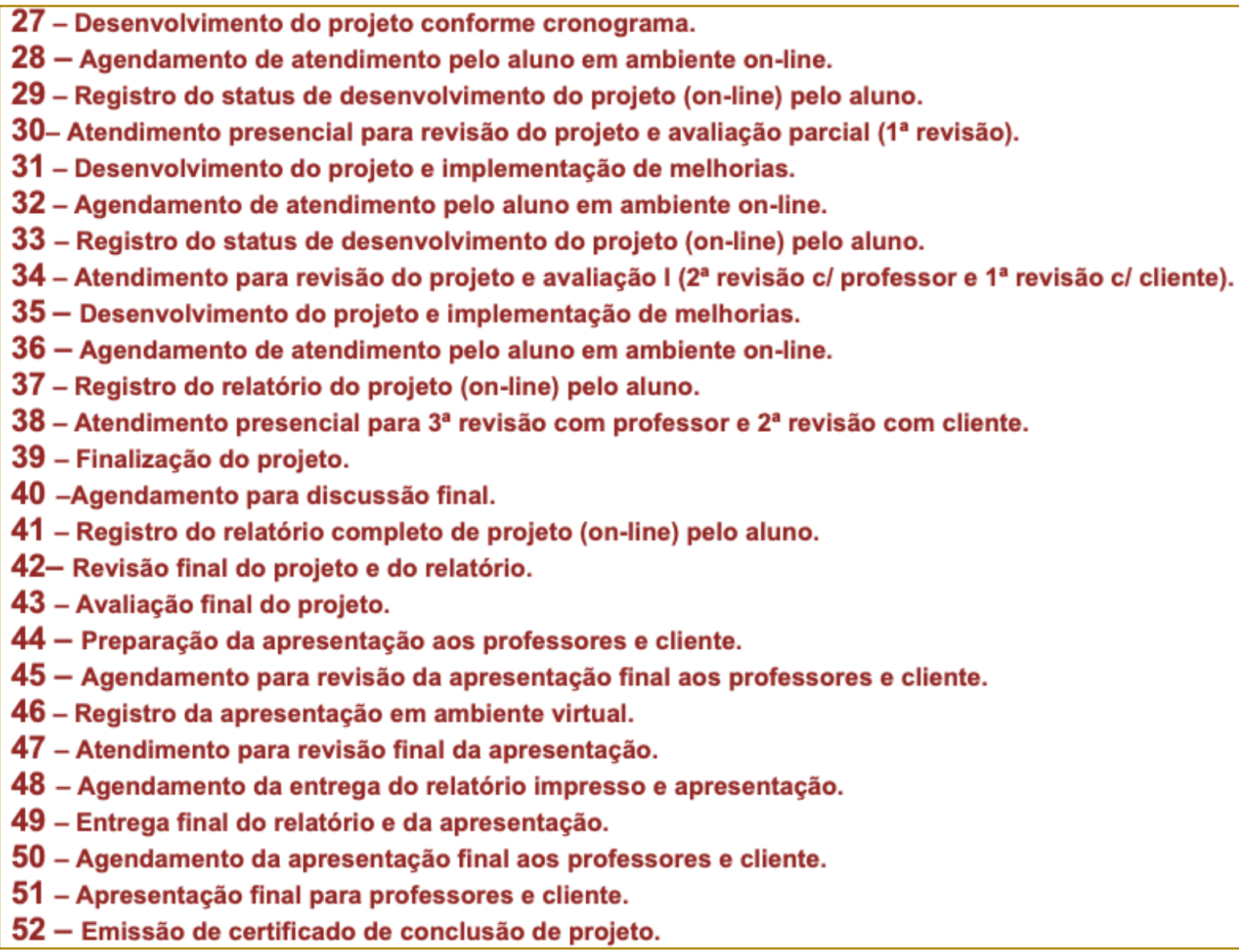

O fluxo apresentado no quadro 6 reflete todo o processo de desenvolvimento do projeto idealizado preliminarmente pelos professores do estúdio, até a fase de finalização, apresentação final e encerramento das atividades.

\section{RESULTADOS E DISCUSSÕES}

O fluxo de processos apresentado pelos professores idealizadores do Estúdio Experimental de Design utiliza-se de um conceito de agendamento de reuniões e entrega de materiais em plataforma digital (sistema on-line utilizado pela instituição) que agiliza 0 fluxo de informações entre professores, alunos, coordenação e secretaria e, desta forma, minimiza a probabilidade de desperdícios com transporte, movimentações desnecessárias, extravio de material e esperas. Entretanto, para garantir a eficácia deste modelo, é essencial que, ao agendar reuniões ou fazer up-load de qualquer material de projeto a ser entregue ao professor pelo sistema on-line, ambos (professores e alunos) recebam confirmação eletrônica a fim de evitar erros de entendimento sobre agendamentos e erros na entrega de material de avaliação nas diferentes fases do projeto.

Outra vantagem dos agendamentos on-line de reuniões é a visualização das agendas de professores, alunos e instituição (pela utilização do Outlook do Office 365), o que possibilita o sincronismo no agendamento de atendimentos, evita reuniões duplicadas, auxilia no controle e planejamento de reuniões e horários e na verificação de disponibilidade dos participantes. Esta ferramenta está relacionada ao conceito Lean por proporcionar maior controle dos horários e do planejamento evitando perdas de tempo, filas e estoques de informações na medida em que o aluno faz o agendamento a partir da finalização de suas tarefas de projeto, ou seja, não precisa esperar por uma reunião préagendada caso finalize uma tarefa antes do previsto, otimizando tempo de projeto. 
O modelo de condução do projeto proposto pelos professores idealizadores, a partir de reuniões presenciais de atendimento, são essenciais no desenvolvimento de um projeto de Design, devido à sua natureza: composto por ilustrações, desenhos, detalhes técnicos, sketches e croquis, a discussão destes itens é mais eficaz quando realizada em reuniões presenciais entre professores, alunos e clientes.

A partir da aplicação da ferramenta Lean VSM (Value Stream Mapping) e dos desperdícios identificados em Serviços por Cronovicz et al.
(2013), foi possível analisar os fluxos idealizados para o Estúdio Experimental de Design e verificar as contribuições do pensamento Lean no desenho de novos fluxos, mais eficazes e enxutos. Os quadros 7 , 8, 9 e 10 apresentam o resultado desta análise em cada um dos fluxos de processos avaliados.

O quadro 7 apresenta os resultados da classificação de cada atividade a ser realizada na fase de Inscrição e Seleção dos alunos a partir da análise de valor agregado.

QUADRO 7 - Análise da relevância das atividades do fluxo de Inscrição e Seleção

\begin{tabular}{|c|c|c|c|c|c|}
\hline \multicolumn{6}{|c|}{ FLUXO DE INSCRIÇÃO E SELEÇÃO } \\
\hline 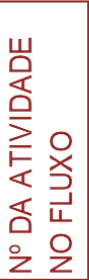 & DESCRIÇÃO DA ATIVIDADE & 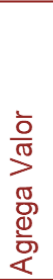 & 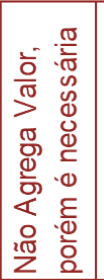 & 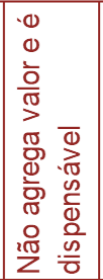 & 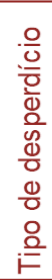 \\
\hline 1 & Divulgação do calendário acadêmico & $x$ & & & \\
\hline 2 & Abertura das inscrições on-line & & $x$ & & \\
\hline 3 & Divulgação aos alunos & & $\mathrm{x}$ & & \\
\hline 4 & Inscrições on-line & & $\mathrm{x}$ & & \\
\hline 5 & Avaliação de elegibilidade do aluno & $x$ & & & \\
\hline 6 & Análise sobre a possibilidade de reavaliação & $x$ & & & \\
\hline 7 & Divulgação aos alunos & & $x$ & & \\
\hline 8 & Agendamento de entrevista & & $x$ & & \\
\hline 9 & Entrevista para avaliação do pré-projeto & $\mathrm{x}$ & & & \\
\hline 10 & Avaliação do pré-projeto & $\mathrm{x}$ & & & \\
\hline 11 & Análise sobre a possibilidade de reavaliação & $\mathrm{x}$ & & & \\
\hline 12 & Agendamento on-line $\mathrm{p} /$ entrevista de planejamento & & $\mathrm{x}$ & & \\
\hline
\end{tabular}

Fonte: os autores

O quadro apresenta as atividades que agregam valor ao processo, as atividades que não agregam valor (mas são necessárias ao processo), e as atividades que não agregam valor e poderiam ser eliminadas do fluxo.
O quadro 8 apresenta os resultados da classificação de cada atividade a ser realizada na fase de Planejamento a partir da análise de valor agregado. 
QUADRO 8 - Análise da relevância das atividades do fluxo de Planejamento

\begin{tabular}{|c|c|c|c|c|c|}
\hline \multicolumn{6}{|c|}{ FLUXO DE PLANEJAMENTO DO PROJETO } \\
\hline 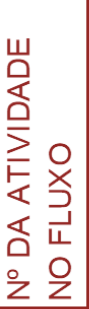 & DESCRIÇÃO DA ATIVIDADE & $\begin{array}{l}\frac{\overline{0}}{\pi} \\
\stackrel{0}{0} \\
\frac{\sigma}{0} \\
\frac{0}{2}\end{array}$ & 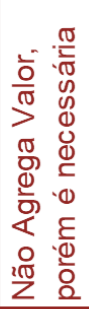 & 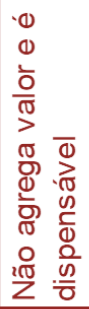 & 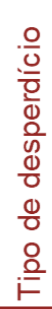 \\
\hline 13 & Entrevista de planejamento & $\mathrm{x}$ & & & \\
\hline 14 & Registro do planejamento por sistema on-line & & $\mathrm{x}$ & & \\
\hline 15 & Levantamento do briefing & $\mathrm{x}$ & & & \\
\hline 16 & Agendamento para apresentação do briefing & & $x$ & & \\
\hline 17 & $1^{\circ}$ atendimento: discussão sobre o briefing & $x$ & & & \\
\hline 18 & Registro do briefing no sistema on-line & & $\mathrm{x}$ & & \\
\hline
\end{tabular}

Fonte: os autores

O quadro apresenta as atividades que agregam valor ao processo, as atividades que não agregam valor (mas são necessárias ao processo), e as atividades que não agregam valor e poderiam ser eliminadas do fluxo.
O quadro 9 apresenta os resultados da classificação de cada atividade a ser realizada na fase de Conceituação a partir da análise de valor agregado.

QUADRO 9 - Análise da relevância das atividades do fluxo de Conceituação

\begin{tabular}{|c|c|c|c|c|c|}
\hline \multicolumn{6}{|c|}{ FLUXO DE CONCEITUAÇÃO DE DESIGN } \\
\hline 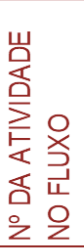 & DESCRIÇÃO DA ATIVIDADE & 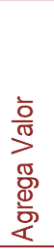 & 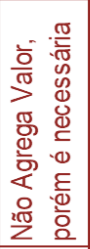 & 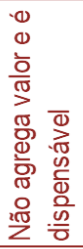 & 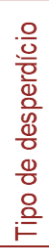 \\
\hline 19 & Pesquisas & $x$ & & & \\
\hline 20 & Registro das pesquisas & & $\mathrm{x}$ & & \\
\hline 21 & Agendamento para discussão dos resultados & & $\mathrm{x}$ & & \\
\hline 22 & $\begin{array}{l}\text { Atendimento para definição da problemática, revalidação do } \\
\text { briefing e início da conceituação }\end{array}$ & $\mathrm{x}$ & & & \\
\hline 23 & Desenvolvimento de propostas conceituais & $\mathrm{x}$ & & & \\
\hline 24 & Agendamento para atendimento & & $x$ & & \\
\hline 25 & $\begin{array}{l}\text { Atendimento para escolha da proposta de design e início do } \\
\text { desenvolvimento do projeto }\end{array}$ & $\mathrm{x}$ & & & \\
\hline 26 & Avaliação e aprovação do conceito & $\mathrm{x}$ & & & \\
\hline
\end{tabular}

Fonte: os autores

O quadro 10 apresenta os resultados da classificação de cada atividade a ser realizada na fase de Desenvolvimento e
Apresentação a partir da análise de valor agregado. 
QUADRO 10 - Análise da relevância das atividades do fluxo de Desenvolvimento e Apresentação

\begin{tabular}{|c|c|c|c|c|c|}
\hline \multicolumn{6}{|c|}{ FLUXO DO DESENVOLVIMENTO E APRESENTAÇÃO } \\
\hline 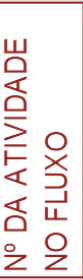 & DESCRIÇÃO DA ATIVIDADE & $\begin{array}{l}\frac{\overline{0}}{\pi} \\
\overbrace{}^{\circ} \\
\frac{\pi}{0} \\
\frac{0}{4}\end{array}$ & 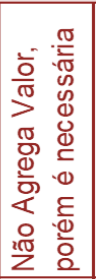 & 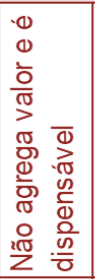 & 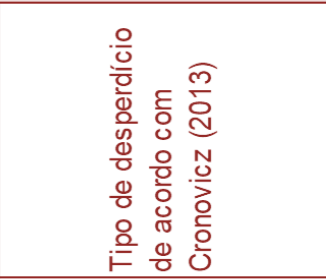 \\
\hline 27 & Desenvolvimento do projeto conforme cronograma & $\mathrm{x}$ & & & \\
\hline 28 & Agendamento $1^{\text {a }}$ revisão & & & $x$ & Revisão desnecessária \\
\hline 29 & Registro do status de desenvolvimenteo & & & $x$ & Revisão desnecessária \\
\hline 30 & $1^{\text {a }}$ revisão do projeto com professor e avaliação parcial & & & $\mathrm{x}$ & Revisão desnecessária \\
\hline 31 & Desenvolvimento de projeto e implementação de melhorias & & & $x$ & Revisão desnecessária \\
\hline 32 & Agendamento para atendimento com professor e cliente & & & $x$ & Revisão desnecessária \\
\hline 33 & Registro do status de desenvolvimento & & & $\mathrm{x}$ & Revisão desnecessária \\
\hline 34 & $\begin{array}{l}2^{a} \text { revisão do projeto, avaliação parcial e } 1^{\text {a }} \text { revisão com } \\
\text { cliente com cliente }\end{array}$ & & & $\mathrm{x}$ & Revisão desnecessária \\
\hline 35 & Desenvolvimento de projeto e implementação de melhorias & & & $x$ & Revisão desnecessária \\
\hline 36 & Agendamento para atendimento com professor e cliente & & & $x$ & Revisão desnecessária \\
\hline 37 & Registro do status de desenvolvimento & & & $\mathrm{x}$ & Revisão desnecessária \\
\hline 38 & $\begin{array}{l}3^{a} \text { revisão do projeto, avaliação parcial e } 2^{a} \text { revisão com } \\
\text { cliente com cliente }\end{array}$ & & & $\mathrm{x}$ & Revisão desnecessária \\
\hline 39 & Finalização do projeto & & & $x$ & Revisão desnecessária \\
\hline 40 & Agendamento para discussão final & $x$ & & & \\
\hline 41 & Registro do relatório de projeto completo & $\mathrm{x}$ & & & \\
\hline 42 & Revisão final do projeto e do relatório completo & $x$ & & & \\
\hline 43 & Aprovação final do projeto & $x$ & & & \\
\hline 44 & Preparação de apresentação à banca & $\mathrm{x}$ & & & \\
\hline 45 & Agendamento para revisão da apresentação & & $\mathrm{x}$ & & \\
\hline 46 & Registro da apresentação & & $\mathrm{x}$ & & \\
\hline 47 & Atendimento para revisão da apresentação & $x$ & & & \\
\hline 48 & Agendamento da entrega do relatório impresso+apresentação & & $\mathrm{x}$ & & \\
\hline 49 & Entega final do relatório impresso e da apresentação & & $\mathrm{x}$ & & \\
\hline 50 & Agendamento da apresentação final para professores e cliente & & $x$ & & \\
\hline 51 & Apresentação final para professores e cliente & $x$ & & & \\
\hline 52 & Emissão de certificado & & $\mathrm{x}$ & & \\
\hline 53 & Postagem do projeto no site de portfólio & $\mathrm{x}$ & & & \\
\hline
\end{tabular}

Fonte: os autores

O quadro apresenta as atividades que agregam valor ao processo, as atividades que não agregam valor (mas são necessárias ao processo), e as atividades que não agregam valor e poderiam ser eliminadas do fluxo.

A partir da aplicação dos conceitos Lean foram realizadas análises dos fluxos iniciais propostos pelos professores do Estúdio experimental, $\mathrm{O}$ que permitiu alguns apontamentos.

O Processo de Inscrição e seleção dos discentes (Quadro 3) foi analisado e apontamse:

Atividade 2 (Abertura das inscrições on-line): recomenda-se que conste no conteúdo do site a data de término das inscrições para que não haja mal entendimento quanto aos prazos limites de inscrição.

Decisões de aceitação (Atividades 5, 6, 10 e 11 - Avaliação da elegibilidade do aluno e do pré-projeto): recomenda-se que os critérios de aceitação sejam esclarecidos no site de inscrição, se estipule um número limite de reavaliações possíveis e informe o estudante a fim de que tenha ciência da possibilidade de não aceitação no programa.

O Processo de Planejamento (Quadro 4) atende aos preceitos Lean por considerar atividades que definem parâmetros essenciais do projeto, como o planejamento (escopo, EAP, Cronograma, Riscos, 
Qualidade entre outros) e a definição de um Briefing (conhecimento das expectativas dos stakeholders, público alvo, expectativas da empresa e investidores entre outros). Recomenda-se que o escopo do que deve ser entregue como planejamento de projeto e o que deve constar no Briefing de projeto sejam informados ao aluno e revisados nas reuniões de planejamento para que todas as eventuais dúvidas possam ser dirimidas antes do início das atividades do projeto, garantindo sua qualidade e evitando desperdício de tempo por uma comunicação ineficaz.

O Processo de Conceituação de Design (Quadro 5) se apresenta com atividades de pesquisa que agregam valor ao projeto pois são essenciais para validação do briefing inicialmente levantado pelo aluno. No caso de o aluno chegar a novas descobertas pelas pesquisas bibliográficas, pesquisas de campo e entrevistas, oriundas da atividade "Pesquisas", o processo de conceituação permite uma revisão de Briefing para que o conceito de Design atenda melhor às necessidades dos stakeholders, aumentando o potencial de qualidade do projeto final.

O Processo de Desenvolvimento

Apresentação do projeto (Quadro 6) e estabelece um fluxo de atividades básicas de projeto e não considera as diferenciações, por exemplo, entre projeto de Design Gráfico e projeto de Design de Produto. Desta forma, recomenda-se que os professores esclareçam aos alunos sobre as atividades exclusivas de cada tipo de projeto a fim de que não haja mal entendimentos em relação a quais entregáveis o aluno deve executar em cada projeto.

Em relação ao fluxo do Processo de Desenvolvimento e Apresentação, percebe-se que um bloco de atividades sequenciais se repete em quatro momentos, indicados no Quadro 11 pelas letras "A", "B", "C" e "D", e que constituem uma sequência lógica de:

- Realização e finalização de uma atividade;

- Agendamento de uma reunião de apresentação, revisão ou aprovação;

- Postagem do material finalizado no sistema on-line; e

- Reunião de apresentação e orientação. 
QUADRO 11 - Blocos de repetição de revisões

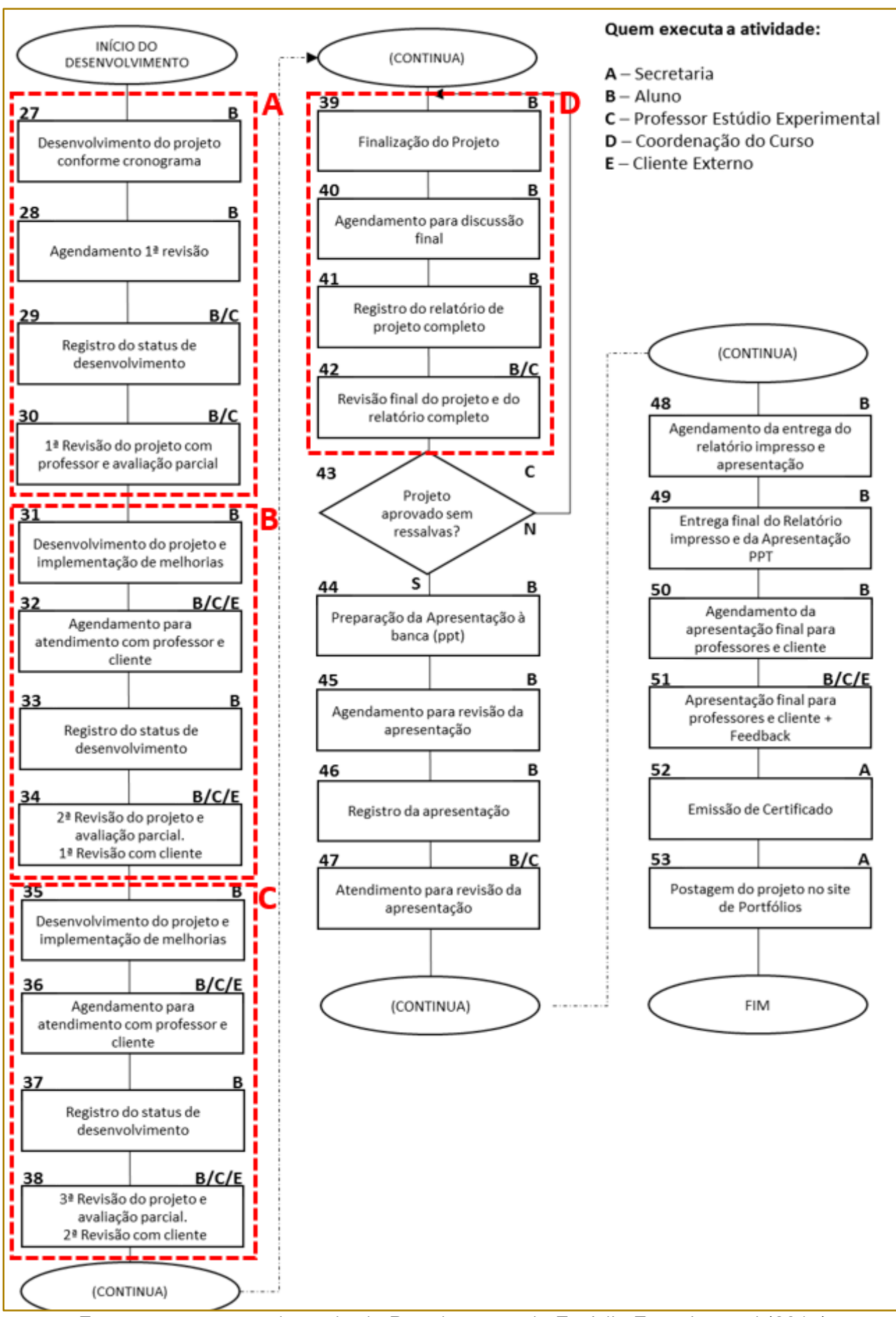

Fonte: os autores, adaptado de Regulamento de Estúdio Experimental (2017)

O quadro 11 apresenta fluxos repetidos com potencial de otimização pela aplicação dos conceitos Lean.

A experiência de um dos autores deste artigo na orientação de projetos em cursos de graduação de design levou a um questionamento durante a análise do fluxo de processos objeto deste estudo: É possível o desenvolvimento de diferentes projetos de design (de variados temas e níveis distintos de complexidade projetual) com o mesmo número de revisões de projeto? Pela natureza e complexidade dos projetos de Design, caracterizados por múltiplas variáveis e diferentes expectativas dos stakeholders, entende-se que é difícil pré-definir 
quantitativamente um número exato de loops de revisão, e ajustes são necessários em cada projeto. Isso implica em assumir que a quantidade de revisões necessárias em cada projeto pode variar. Há projetos que não necessitam de mais que uma revisão, outros que exigem mais de três revisões para que tenham qualidade. A partir desta lógica e da aplicação do conceito Lean e a ferramenta
VSM (Value Stream Mapping) para se evitar perdas e desperdícios, sugere-se que esses blocos de atividades projetuais e revisões tenham maior flexibilidade no fluxo de processos, evitando perdas de tempo quando revisões adicionais não são necessárias. Considerando esta contribuição, um novo fluxo de processos sugerido é ilustrado no Quadro 12.

QUADRO 12 - Sugestão de Fluxo de Processos de Desenvolvimento e Apresentação

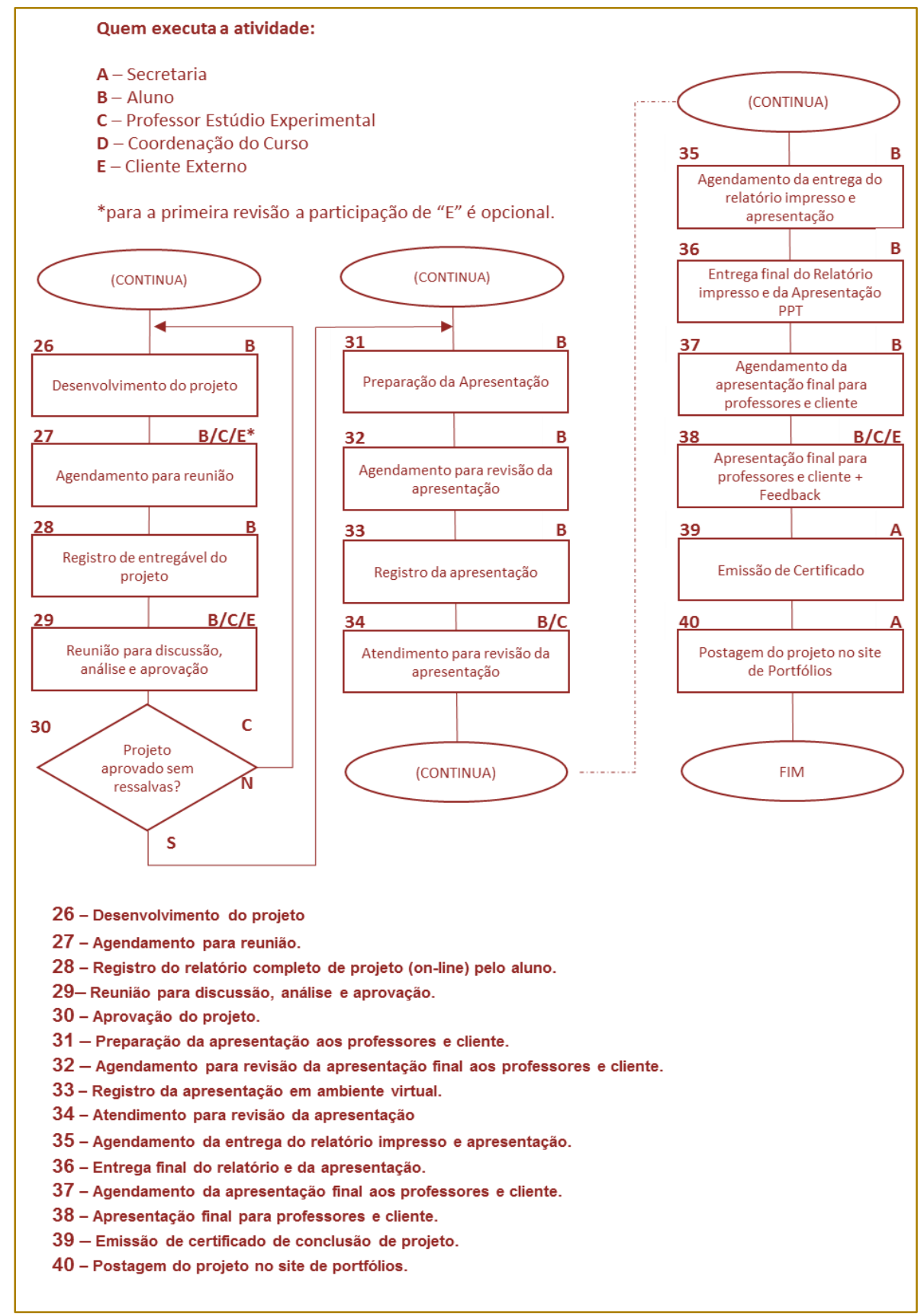

Fonte: os autores, adaptado de Regulamento de Estúdio Experimental (2017)

O quadro 12 apresenta a otimização sugerida a partir da aplicação dos conceitos Lean para o fluxo dos processos relacionados às fases de Desenvolvimento e Apresentação. 


\section{CONCLUSÕES}

A partir das pesquisas realizadas, tendo como objeto de pesquisa um Estúdio Experimental de Design, utilizando-se de análise documental, entrevistas e reuniões, foi possível entender os objetivos e a dinâmica deste tipo de serviço oferecido por meio de orientação a alunos de Design em uma instituição de ensino superior.

A partir do entendimento de todas as fases que compreendem este serviço (inscrição, processo seletivo, planejamento, conceituação, desenvolvimento do projeto e finalização), conclui-se que os Sistemas Lean podem contribuir para maior eficácia nos serviços prestados a partir de duas abordagens:

- $\quad$ pelo uso da ferramenta Lean de Fluxo Puxado (Pul/), pôde-se analisar como as informações fluem no fluxo de processos proposto e sugerir como contribuição, maior foco na forma e aos detalhes com que as atividades serão desenvolvidas entre alunos, professores e instituição, sobretudo nas relações de comunicação entre estes agentes, com foco no alinhamento de informações e no cuidado em garantir a exata interpretação e feedback das atividades desenvolvidas. Estas recomendações foram apontadas principalmente para as atividades

\section{BIBLIOGRAFIA}

[1]. ASIF, M; LOWIK, S.; WEUSTHOF, W; DE BRUIJIN, E. J. Challenges in Lean Implementation in Knowledge-Intensive Services. Proceedings of the 15th Cambridge International Manufacturing Symposium. Cambridge: set/2010, pp. 1-17.

[2]. BICHENO, J; HOLWEG, M. The Lean Toolbox: The Essential Guide to Lean Transformation. Buckingham: Picsie Books, 2009.

[3]. GRONOVICZ, M. A; BITTENCOURT, M. I. P. de; SILVA, S. B. G. da ; FREITAS, M. C. D.; BIZ, A. A. Lean Office: Uma Aplicação Em Escritório De Projetos. Gestão \& Conhecimento, v. 7, n.1, jan.jjun. 2013: Pág. 48 - 74.

[4]. LAREAU, W. Office kaizen: transforming Office operations into a strategic competitive advantage. USA: ASQ, Quality Press:2002. das fases de Inscrição e seleção e nos processos de Planejamento do projeto.

- pela aplicação da ferramenta Lean VSM (Value Stream Mapping) pôde-se analisar o fluxo atual de processos e sugerir melhorias, essencialmente na etapa de desenvolvimento e apresentação, pela recomendação de ajustes no fluxograma a fim de evitar revisões desnecessárias de projeto e desperdício de tempo.

Percebeu-se também que, ainda que de forma inconsciente, os professores idealizadores já aplicaram conceitos Lean que aumentam a eficácia dos processos ao optarem por:

Ferramentas digitais para agendamentos - o que possibilita agilidade, praticidade e controle no planejamento de reuniões;

Arquivamento digital de materiais dos alunos o que minimiza a estoques de desenhos e documentos físicos.

Ante o exposto, verificou-se que a questão de pesquisa foi respondida. Conclui-se que a aplicação dos sistemas Lean em um estúdio experimental de design contribui no desenvolvimento de projetos acadêmicos num escritório de design a partir da criação de fluxos de processos mais eficazes.

[5]. LEAN INSTITUTE DO BRASIL. A filosofia Lean. Disponível em:<http://www.Lean.org.br/>. Acesso em: 03 nov. 2017.

[6]. MELLO, C.H.P. Modelo para projeto e desenvolvimento de serviços. Tese (Doutorado em Engenharia). Escola Politécnica da Universidade de São Paulo. São Paulo: Escola Politécnica da Universidade de São Paulo, 2005, p.332.

[7]. OHNO, T. O Sistema Toyota de Produção: Além da Produção em Larga Escala. Porto Alegre: Editora Bookman, 1997.

[8]. WOMACK, J. P.; JONES, D. T. A Máquina que Mudou o Mundo. Rio de Janeiro: Editora Campus, 2004.

[9]. Lean Thinking: Banish Waste and Create $\overline{\text { Wealth }}$ in Your Corporation. Nova York: Simon and Schuster Ed. 2003. 


\section{APÊNDICE 1 - ROTEIRO DE ENTREVISTA - CONTEXTUALIZAÇÃO DO OBJETO DE ESTUDO}

Questionário aplicado aos professores Idealizadores do estúdio experimental de design.

Nome:

Idade:

Disciplinas em que atua:

1. Quais são os objetivos do estúdio experimental de design?

2. A quem se destina os serviços prestados?

3. Quais serviços serão prestados pelo estúdio?

4. Quais os principais processos necessários para a execução dos serviços prestados?

5. Por sua experiência como docente orientador de projetos de design, é possível prever algum risco de espera ou gargalos nos atendimentos? Se sim, em qual parte do processo?

6. Como se pretende efetuar os registros das atividades/processos do estúdio (desde o primeiro contato com o cliente até a finalização do projeto)?

7. No caso de a demanda se apresentar maior do que a capacidade de atendimento, o que poderia ser feito para minimizar as esperas?

8. Como serão realizados os registros de inscrição, seleção, acompanhamento, avaliações e conclusão dos projetos (em ambientes virtuais ou fichas e relatórios físicos)?

9. Como se pretende realizar a dinâmica dos atendimentos para acompanhamento dos projetos (local, frequência, duração, registro de atividades)?

10. Como serão executados os sistemas de avaliação e aprovação dos projetos (periodicidade, critérios, duração, feedback)?

11. Há algum conhecimento de processos de outros estúdios que possam contribuir como "lessons learned"na criação deste estúdio experimental de design? 


\section{Capítulo 13}

\section{ESTUDO DE CASO SOBRE A REDUCÃO DE LEAD TIME EM ATIVIDADE DE SEPARAÇÃO E EXPEDIÇÃO}

\section{Leandro de Souza Santos}

\section{Paulo Cesar Giuliani}

Resumo: Este trabalho analisa os obstáculos enfrentados pela separação e expedição de produtos em uma indústria têxtil, cujas falhas nesses processos têm impacto no lead time de entrega ao cliente. Tal abordagem é relevante, pois mostra a aplicação de ferramentas de racionalização industrial para tornar a logística da empresa mais enxuta. Para tanto é necessário fazer um planejamento que alcance uma expedição mais eficiente. A análise foi desenvolvida por meio de estudo de caso realizado através de coletas de dados, em que foram evidenciados os problemas enfrentados pela empresa quanto à expedição de produtos. O propósito dessa pesquisa é analisar os conceitos de técnicas na operação logística da empresa, fazendo com que a separação e a expedição dos produtos aconteçam conforme planejado, buscando assim, reduzir o lead time de entrega, e com isso aumentar a satisfação do cliente. A partir das evidências será proposto um conjunto de ações, nos quais, proporcionam redução de atividades desnecessárias e de melhorias nos processos. O artigo apresenta, finalmente, os efeitos da análise do estudo de caso seguido da discussão de seus resultados e conclui que através das técnicas utilizadas no estudo, a empresa alcançaria uma redução no lead time de entrega, tendo a execução de suas operações de separação e expedição de forma mais eficiente.

Palavras-chave: Estoque. Mapeamento. Produto. Cliente. 


\section{INTRODUÇÃO}

Nos dias de hoje as empresas buscam melhorar seus desempenhos, para serem competitivas. As empresas precisam de: melhor desempenho e agilidade no lead time de separação, expedição, satisfação dos clientes, custos baixos, processos mais lucrativos, dessa forma as empresas investem em técnicas de gestão que permitem sobressair no mercado atuante. Na busca da competitividade a empresa analisada iniciou estudo sobre os obstáculos enfrentados pela separação e a expedição de capas de bancos para carros em uma indústria de fabricação de produtos automotivos, onde falhas nesse processo têm impacto direto no lead time de entrega ao cliente, acreditando que uma melhoria no setor, melhore o resultado da empresa. Esse artigo tem como objetivo analisar a eficácia das técnicas de gestão na otimização do tempo de separação e expedição, buscando a melhoria do processo e uma maior satisfação do cliente, reduzindo o lead time de entrega e consequentemente aperfeiçoando o potencial competitivo da empresa. O universo da pesquisa é uma empresa que fabrica e distribui revestimento interno para veículos automotivos (capas para bancos de carro zero $\mathrm{Km}$ ) para fornecedores de bancos de carro as principais montadoras de veículos automotivo do país. Os maiores problemas visto nesse meio, que gera um maior lead time de entrega, é quanto à separação e a expedição dos produtos, pois devido à demanda diária, falta de padronização, e a grande variedade de produtos, alguns processos são falhos e desnecessário. À analise foi desenvolvida a partir de uma pesquisa bibliográfica e documental em artigos científicos e livros direcionado ao tema com a finalidade de obter base para a realização do estudo de caso. O referêncial teórico iniciará com uma breve introdução à logística lean, seguido da apresentação de ferramentas de controle, finalizando com definição de lead time e a importância de atendimento ao cliente.

\section{REFERÊNCIAL TEÓRICO}

\subsection{JUST IN TIME}

O just in time é uma abordagem que visa aprimorar a produtividade global e eliminar os desperdícios. Ele possibilita a produção eficaz em termos de custos, assim como, obter apenas as quantidades necessárias, na quantidade correta, e no momento e locais corretos utilizando o mínimo das instalações, equipamentos, materiais e recursos humano. Ele é alcançado através da aplicação de elementos que requer um envolvimento total dos funcionários e trabalho em equipe. (SLACK et. al. 2009).

"A produção em lotes pequenos, feitos na hora certa que são demandados pelo cliente, leva a estoques menores, quer seja de matéria prima, de materiais semiprocessado, quer seja, de produtos acabados. (MOREIRA p.509, 2005).

Para Slack assim como, para Moreira as quantidades de materiais em processo devem estar nas quantidades corretas que são demandadas, fazendo com que, todo o processo seja, mais eficaz e com menos desperdícios, sendo ele, de tempo, de produção ou utilização dos recursos. E isso se faz, com total envolvimento da equipe.

\subsection{ESTOQUES}

"Estoques são acumulações de matérias primas, suprimentos, componentes, materiais em processo e produtos acabados, figuram normalmente em lugares como armazéns, pátios e chão de fábrica". (BALLOU p. 271, 2006).

Ainda segundo Ballou (2006). Gerenciar estoques é também equilibrar a disponibilidade dos produtos; um objetivo primário do gerenciamento de estoques é garantir que o produto esteja disponível no tempo e nas quantidades necessárias.

É muito comum as pessoas ficarem desapontadas, e ao mesmo tempo fascinadas, quando encontram elevados níveis de estoques, quer seja de matériasprimas, produtos em trânsito ou acabados. Mensurar os níveis de estoque ajuda a medir o lead time, indicador muito importante. (FERRO 2005).

\subsection{EMBALAGEM DOS PRODUTOS}

A maioria dos produtos é distribuída com algum tipo de embalagem. São várias as razões na qual se incorre na despesa com embalagem. A motivação pode ser a de:

- Facilitar a armazenagem e manuseio;

- Promover melhor utilização do equipamento de transporte; 
- Dar proteção ao produto;

- Promover a venda do produto;

- Alterar a densidade do produto;

- Facilitar o uso do produto.

Nem todos esses objetivos são alcançáveis por meio do gerenciamento logístico. Entre tanto, a mudança da densidade do produto e a embalagem protetora são preocupações desta área. (BALLOU 2006).

Ainda segundo Ballou a embalagem protetora é uma dimensão especialmente importante do produto para o planejamento logístico. Em muitos aspectos, a embalagem precisa ser 0 foco do planejamento, é a embalagem que tem forma volume e peso.

\subsection{PARETO OU 80/20}

Normalmente uma empresa mantém centenas e, com frequência milhares de item em estoque. Gerenciar os estoques de todo esses itens com a mesma atenção e os mesmo métodos pode ser bastante custoso, obrigando a que encontre alguma forma de dar atenção diferenciada a certos itens. Para isso, é necessário que adote um critério, que permite distinguir claramente a importância da mercadoria seguindo esse critério. (MOREIRA 2008).

Uma forma comum de discriminar entre diferentes itens de estoques é classificá-los pelo seu valor de consumo (taxa de consumo multiplicado pelo valor). Em geral, uma proporção relativamente pequena do total de itens contidos num estoque será responsável por grande proporção do valor total do consumo. Esse fenômeno é conhecido como o Pareto, ou regra 80/20 é chamado assim por que $80 \%$ das vendas de uma operação são causadas por $20 \%$ de todos os tipos de itens estocados. (SLACK et. al. 2013).

\subsection{MAPEAMENTO DE PROCESSOS}

"O mapeamento de processos é definido como o envolvimento de atividades que se relacionam dentro do processo". (SLACK et. al 2009). Para Slack, Chambers e Johnston a vantagem do mapeamento de processo é que envolve toda atividade dentro do sistema, tornando-as visíveis para identificar e aprimorar o processo.

\subsection{MAPEAMENTO DE FLUXO DE VALOR}

Segundo Ferro (2005) a metodologia de Mapeamento do Fluxo De Valor (MFV) é capaz de gerar uma visão horizontal dos processos que agregam valor. Segundo o autor isso significava romper com a perspectiva tradicional de examinar departamentos ou funções e enfatizar as atividades, ações e suas conexões no sentido de criar valor e fazê-lo flui, desde os fornecedores até os clientes finais. É importante que a ferramenta seja aplicada de forma concreta, pois fazer por fazer não a torna uma estratégia válida. Isso irá assegurar que estados futuros de melhoria aconteça salientado no fluxo atividades que agregam valor ao processo.

Para Moreira (2010) O Mapeamento do Fluxo de Valor (MFV) é um método muito útil e tem sido um dos mais utilizados no universo de aplicações da filosofia lean em empresas industriais. Permite identificar as atividades que acrescentam valor, as que não acrescentam valor, mas são necessárias e as desnecessárias. Partindo desta análise consegue-se elaborar um novo fluxo, mas com menos desperdícios.

\section{METODOLOGIA}

O artigo a ser desenvolvido a partir de uma pesquisa exploratória com 0 intuito de recolher informações que permitam apresentar um estudo de caso relacionado às técnicas e estratégias no setor de separação e expedição em uma empresa de produtos automotivos. A partir disso, foi desenvolvido um estudo a fim de reduzir o lead time de entrega e atender de forma mais rápida o pedido do cliente. O estudo foi realizado através da análise do fluxo de operações, seguido da medição do tempo de cada atividade até a expedição do produto, onde foi realizado o mapeamento do processo atual e proposto o processo futuro, com redução de atividades desnecessárias.

\section{A EMPRESA E SUA SITUAÇÃO ATUAL}

A empresa em questão é uma multinacional que busca satisfazer às necessidades de seus clientes com eficiência, está em constante crescimento no mercado de revestimento automotivo por isso ela emprega a filosofia de melhoria continua de seus processos. O processo de separação e 
expedição de produtos feitos pela empresa estudada possui uma alta complexidade, visto que os produtos têm diferentes embalagens e as atividades são manuais. A empresa possui um amplo estoque, há diferentes tipos de embalagens, sendo caixas e pacotes com quantidade de peças variadas. $O$ fluxo do processo pesquisado e desenvolvido envolve desde o recebimento de ordem para faturamento até a expedição do mesmo, buscando o melhor atendimento. $\mathrm{O}$ mapeamento de processo descrito no apêndice A (ideal ao processo) identifica quais os setores envolvidos nesse meio, bem como as atividades a serem desenvolvidas por eles até o destino final dos produtos. 0 esquema descrito no mapeamento de processo envolve o setor de expedição da empresa, compreendendo atividades do administrativo e operacional, onde a perfeição na execução de cada um é essencial, visto que um bom atendimento ao cliente torna a empresa mais competitiva no mercado. Com base no cenário atual foi possível observar há dificuldade, desperdício de tempo e movimento, uma vez que para cada processo de retirada e realocação de material, os produtos são mal distribuídos e alocados nos corredores sem a devida atenção para a importância de cada item. No próximo tópico, serão analisadas as medições dos tempos para a execução de cada atividade deste processo.

\section{COLETA DE DADOS COM MEDIÇÃO DE TEMPO}

Para entender e identificar os gargalos na separação e expedição dos produtos acompanhamos todo o processo, desde o recebimento da ordem para faturamento até a expedição dos produtos para o cliente, a fim de mensurar quais atividades poderiam ser melhoradas ou até mesmo eliminadas do processo. A análise foi realizada partir de um pedido cujas informações estão destacadas na tabela abaixo. A mão de obra envolvida no processo foi: 1 faturista (Faturamento), 1 operador de empilhadeira (Operação), 1 operador de conferencia (Operação), além de 2 pessoas da transportadora para conferencia e carregamento.

TABELA 1 - Dados do Roteiro

\begin{tabular}{|l|c|}
\hline Quantidade de códigos & 97 \\
\hline Quantidade de volumes & 390 \\
\hline Quantidade de peças & 6010 \\
\hline Quantidade de paletes & 50 \\
\hline Quantidade de paletes completos & 20 \\
\hline Quantidade de paletes separados & 30 \\
\hline Total de volumes completos & 20 \\
\hline Total de volumes separados & 370 \\
\hline
\end{tabular}

Fonte: O autor (2018)

As atividades realizadas atualmente para separar e expedir os produtos da empresa estudada, bem como o tempo gasto em cada uma delas está descrito na tabela abaixo, onde conseguiremos identificar de forma claras possíveis melhorias para o processo. 
TABELA 2 - Dados do Roteiro

\begin{tabular}{|l|c|c|}
\multicolumn{1}{|c|}{ SEQUÊNCIA DAS ATIVIDADES } & $\begin{array}{c}\text { TEMPO } \\
\text { (min) }\end{array}$ & SETOR \\
\hline 1. Criar lista de separação & 10 & FATURAMENTO \\
\hline 2. Preparação para separação dos itens da lista & 6 & OPERAÇÃO \\
\hline 3. Verificar na lista os endereços de separação & 3 & OPERAÇÃO \\
\hline 4 Separação dos itens da lista & 180 & OPERAÇÃO \\
\hline 5 Empilhadeira baixa os paletes da separação & 40 & EMPILHADEIRA \\
\hline 6 Movimentação dos paletes para as docas & 6 & OPERAÇÃO \\
\hline 7. Gerar nota fiscal & 30 & FATURAMENTO \\
\hline 8. Conferência do material X nota via sistema & 10 & FATURAMENTO \\
\hline 9. Conferência da transportadora & 30 & TRANSPORTADOR \\
\hline 10. Carregamento & 30 & TRANSPORTADOR \\
\hline Tempo total da operação & 334 & \\
\hline
\end{tabular}

Fonte: O autor (2018)

A tabela abaixo demonstra o lead time encontrado após o acompanhamento da execução de todas as atividades e mensuração dos tempos, obtendo um total de 06h49min horas para separação e expedição do pedido analisado.

\section{TABELA 3 - Dados do Roteiro}

\begin{tabular}{|l|l|l|}
\hline \multicolumn{1}{|c|}{ Tempo total da operação } & $04: 34: 00$ & Horas \\
\hline Tempo de conferencia e carregamento do transportador & $01: 00: 00$ & Horas \\
\hline Tempo total da operação + carregamento & $05: 34: 00$ & Horas \\
\hline Lead time total (horário de refeição + café) & $06: 49: 00$ & Horas \\
\hline Fonte: O autor (2018) & &
\end{tabular}

Com todos os dados de atividades e tempos coletados, foi realizado o mapeamento de fluxo de valor (MFV) atual, onde identificamos de forma clara os processos que agregam valor (Faturamento) e os que não agregam valor (operações, empilhadeira, transportador), encontrando os resultados descritos na figura abaixo.

Figura 1 - Dados do Mapeamento de Fluxo de Valor.

\begin{tabular}{|l|l|}
\hline $\mathbf{1 7 , 6 1 \%}$ & $\begin{array}{l}\text { Não agrega valor: } 4,73 \\
\text { horas }\end{array}$ \\
$\mathbf{8 2 , 3 9 \%}$ & \\
& Agrega valor: 0,83 horas \\
\hline
\end{tabular}

Fonte: O autor (2018)

No próximo tópico serão abordadas possíveis soluções para o caso apresentado, a fim de melhorar os processos da empresa, com o propósito de obter maior rapidez na separação e expedição dos produtos e consequentemente um melhor atendimento ao cliente. 


\section{PLANO DE AÇÕES}

Com o resultado da medição e análise das atividades foram identificadas possíveis melhorias, onde foi proposto planos de ações que possibilitariam reduzir atividades desnecessárias e pontos de melhoria para execução eficiente. A tabela abaixo demonstra os principais pontos que foram propostos para diminuição do tempo de separação e expedição.

TABELA 4 - Proposta

\begin{tabular}{|l|l|}
\hline 1 & ORGANIZAÇÃO DOS PRODUTOS DE SOLO MAIS PROXIMOS DAS DOCAS \\
\hline 2 & SEPARAÇÃO DA LISTA POR ORDEM SEQUENCIADA \\
\hline 3 & AUMENTO DE NUMERO DE PEÇAS POR MULTIPLO \\
4 & ORGANIZAÇÃO DOS PACOTES EM LOTES PADRÃO DE 60 PEÇAS POR CAIXA \\
5 & VERIFICAR LENTIDÃO NO SISTEMA DE FATURAMENTO \\
\hline 6 & COORDENAÇÃO DA SEPARAÇÃO DOS PRODUTOS CHÃO E ALTO \\
\hline 7 & DILUIR VENDAS NA SEMANA INTEIRA \\
\hline
\end{tabular}

Fonte: O autor (2018)

\section{RESULTADOS E DISCUSSÃO}

Em decorrência do que foi apresentado na seção 5, uma comparação dos dois resultados revela pontos de melhoria identificados, foi apresentado o mapeamento do fluxo de valor (MFV) futuro demonstrado no apêndice (B), com a suposta aplicação dos pontos destacados acima. A figura abaixo se refere ao resultado do MFV futuro, o que tornaria o processo mais eficiente.

Figura 2 - Dados do Mapeamento de Fluxo de Valor Futuro. (Apêndice B).

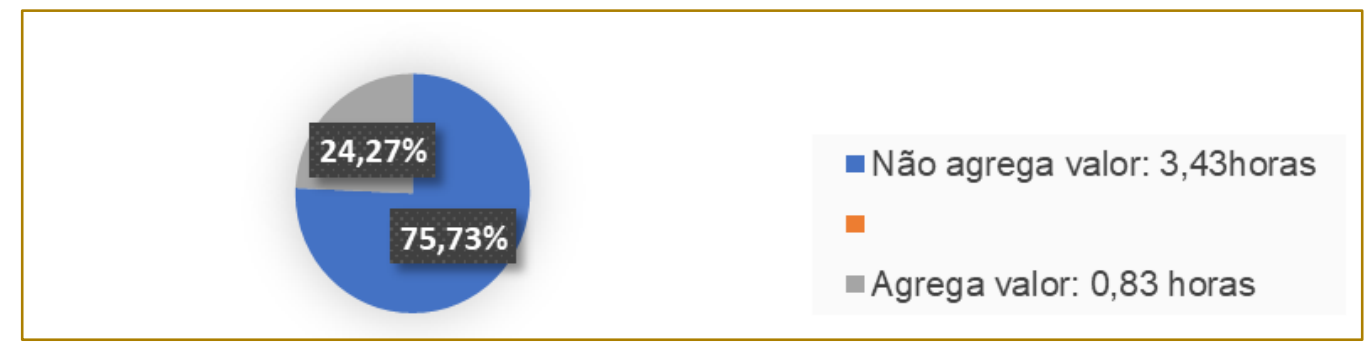

Fonte: O autor (2018)

Com intuito de realizar uma análise comparativa do MFV atual e futuro, realizamos a tabela a seguir, onde evidenciamos as porcentagens de melhoria. Com isso, identificamos que com a aplicação das melhorias propostas reduziríamos o lead time em $23 \%$.

Tabela 5 - Análise comparativa Comparação entre MFV atual e futuro

\begin{tabular}{|c|c|c|c|}
\hline Estado atual: & \multicolumn{3}{|c|}{ Estado futuro: } \\
\hline $\begin{array}{c}\text { Tempo total } \\
\text { operação+ carregamento }\end{array}$ & $05: 34: 00$ & $\begin{array}{c}\text { Tempo total } \\
\text { operação+ carregamento }\end{array}$ & $04: 16: 00$ \\
\hline Tempo eliminado & $01: 18: 00$ & Ganho & $23 \%$ \\
\hline
\end{tabular}

Fonte: O autor (2018) 
Além das melhorias identificadas no MFV, o estudo realizado propõe uma distribuição de acordo com a classificação de Pareto (apêndice C), alocando os produtos de classe A (de maior prioridade) em locais de fácil acesso, em seguida produtos de classe $B$ (de media prioridade) e classe $\mathrm{C}$ (de baixa prioridade) no mesmo nível da rua, facilitando o acesso a todos eles e evitando que os produtos fiquem alocados em ordem errada. Contudo, para a aplicação do estudo a empresa deve estar disposta a investir nas melhorias apresentadas, que é vantajoso a longo prazo, pois além da redução no lead time de entrega para o cliente, a empresa estaria melhorando seus processos internos e reduzindo seus custos

\section{CONSIDERAÇÕES FINAIS}

A utilização de técnicas lean no gerenciamento, adequadas à realidade da empresa, possibilitam meios de redução nas operações de expedição e separação evitando movimentação desnecessária desde o recebimento das ordens para faturamentos até a expedição dos produtos, proporcionando agilidade no atendimento aos clientes. Este estudo mostrou que existem

\section{REFERÊNCIAS}

[1]. BALLOU, R. H. Gerenciamento da cadeia de suprimentos / logística empresarial. 5. Ed. Porto Alegre: Bookman, 2006 reimpressão 2010.

[2]. FERRO, José R. A essência da ferramenta Mapeamento do Fluxo de Valor, 2005. Disponível em <https://www.lean.org.br/artigos/61/a-essenciada-ferramenta-mapeamento-do-fluxo-devalor.aspx> Acesso em: 19 março 2018.

[3]. MOREIRA, Filomena. Mapeamento de Fluxo de valor (ValueStreamMapping), 2010. Disponível em: <https://www.portalgestao.com/artigos/6172-mapeamento-do-fluxo-devalor-value-stream-mapping.html>. Acesso em: 20 março 2018. atividades desnecessárias envolvidas no sistema que ocasionam em tempos longos de atendimento de um pedido e insatisfação por parte do cliente, fazendo com que empresas percam sua credibilidade e colocação no mercado. Para garantir a rapidez na entrega de um pedido ao cliente, o estudo propôs a aplicação de técnicas como Mapeamento de Processo (MFV), cronoanálise e Pareto ou 80/20 no setor de logística, onde através da identificação das atividades e tempos envolvidos no processo, foi realizado planos de ação para eliminação daquelas que não agregam valor, no qual revelou através do MFV futuro que a empresa alcançará uma significativa melhora no lead time de entrega. É importante destacar que além de melhorar o atendimento ao cliente, a aplicação deste estudo trará eliminação de desperdícios como transporte interno, espera por parte do colaborador, movimentação, bem como retrabalho por parte dos colaboradores da empresa. Portanto a aplicação de técnicas de gestão logística é capaz de conduzir empresas a executar suas operações de separação e expedição de uma maneira mais eficiente.

[4]. SLACK, Nigel; CHAMBERS, Stuart; JOHNSTON, Robert. Administração da produção. São Paulo: Atlas, 2009.

[5]. SLACK, Nigel; CHAMBERS, Stuart; JOHNSTON, Robert; BETTS, Alan. Gerenciamento de operações e de processos: princípios e práticas de impacto estratégico 2.ed. Porto Alegre: Bookman, 2013.

[6]. MOREIRA, Daniel Augusto Administração da produção e operações. 2. Ed. rev. e ampl. - São Paulo: Cengage Learning,2015. 
APÊNDICE A

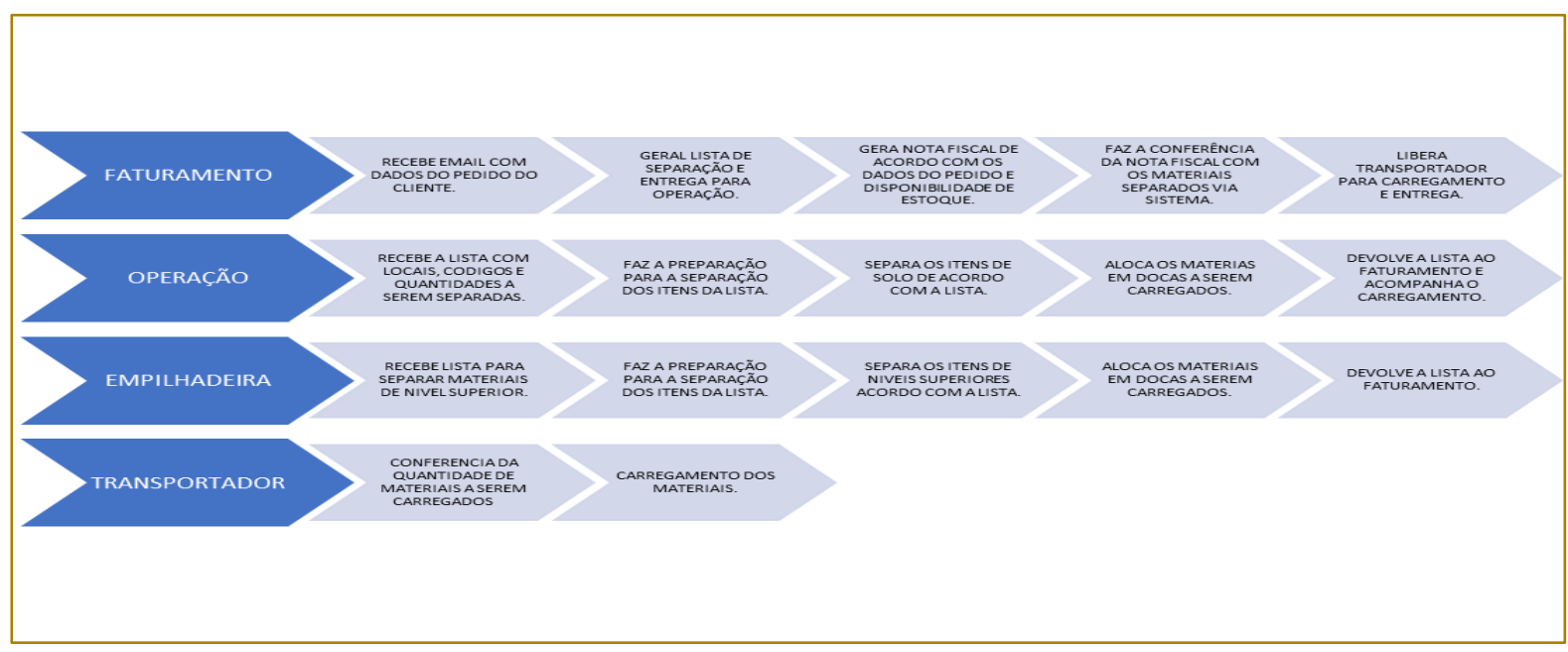

APÊNDICE (B)

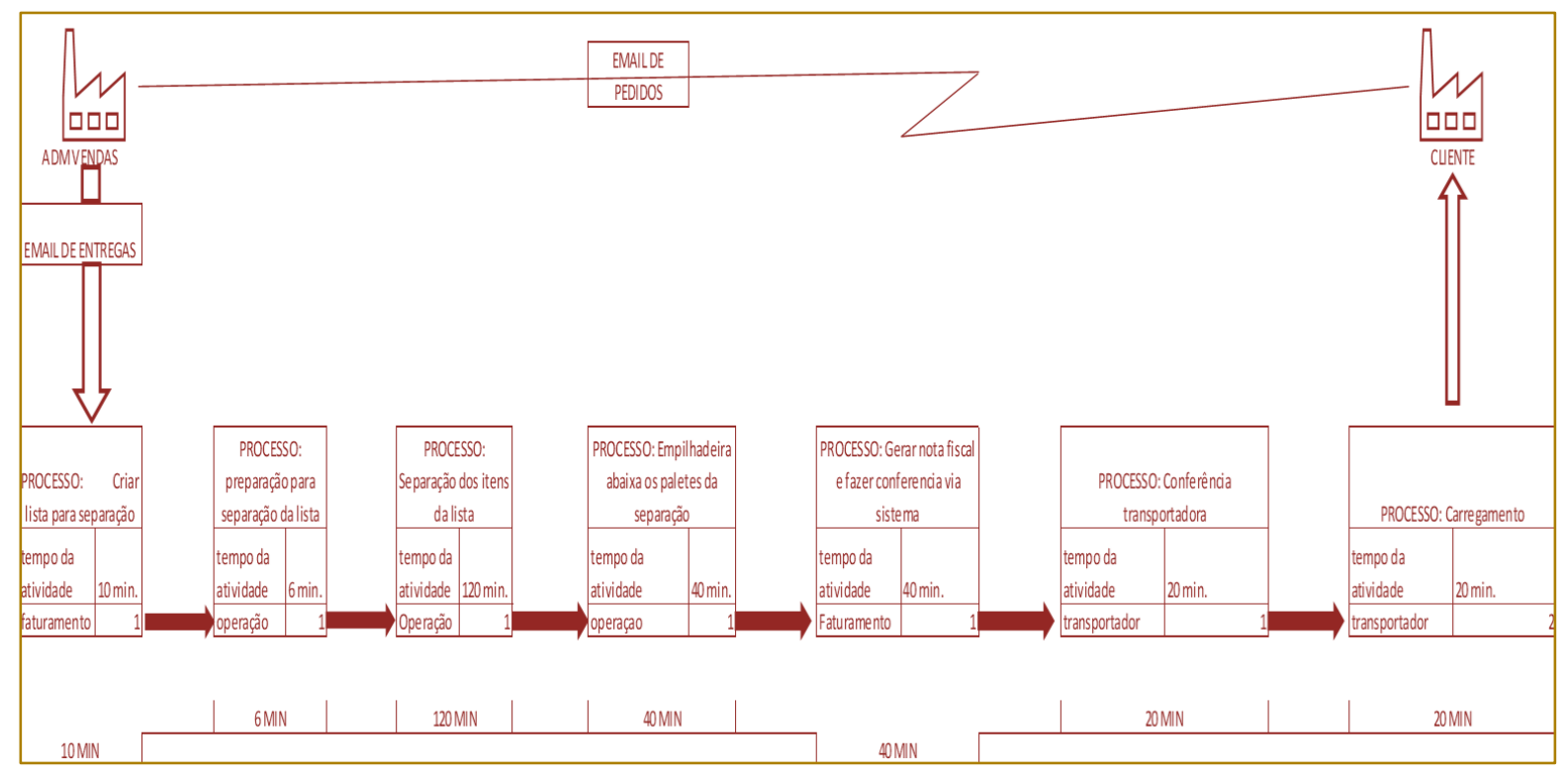


APÊNDICE (C)

Antes

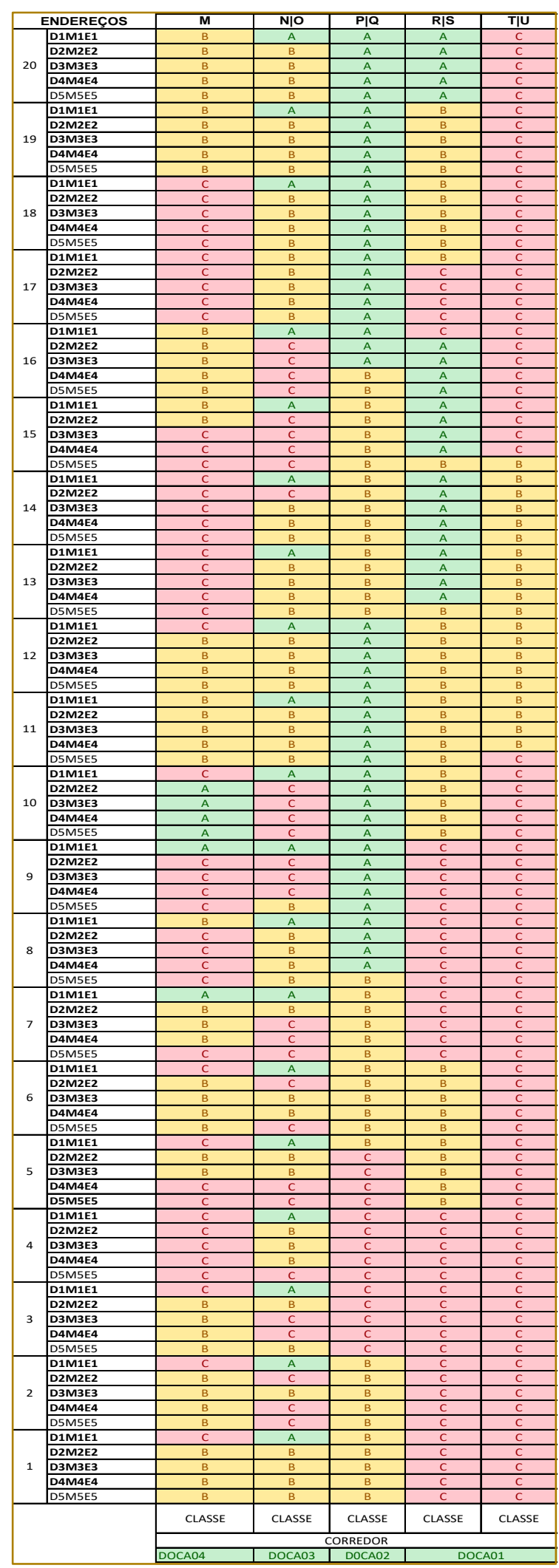

Depois

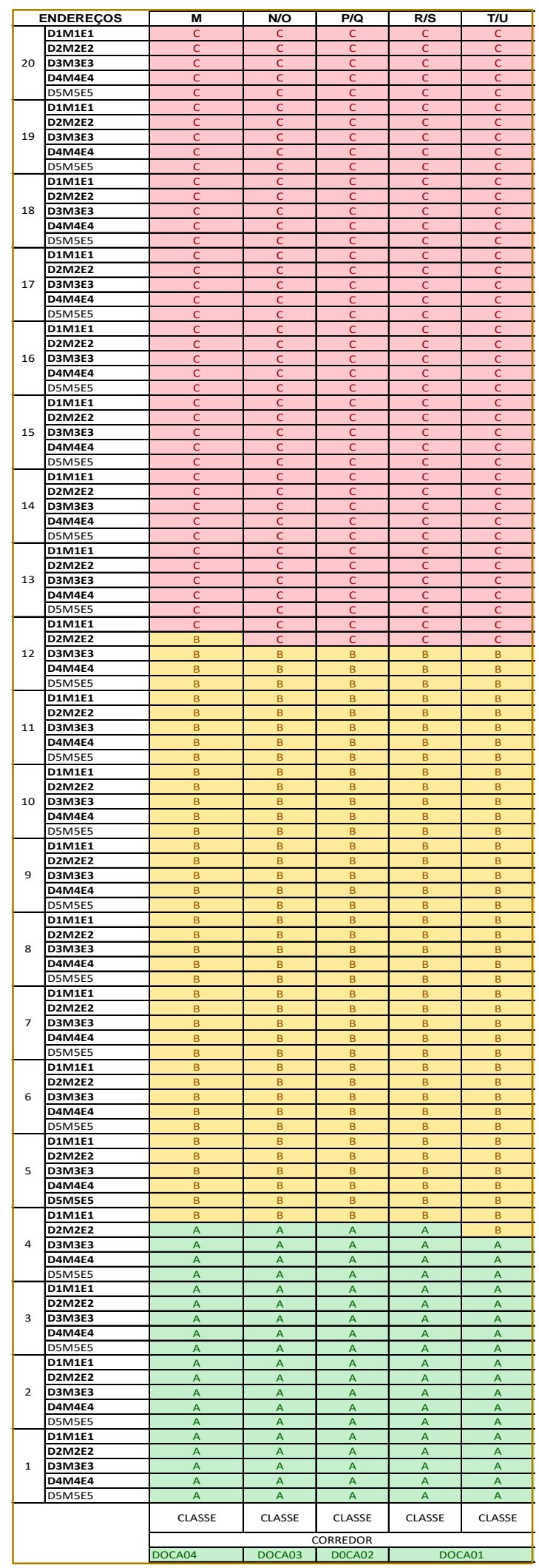




\section{Gapítulo 14}

\section{MELHORIA DO TRÂNSITO EM UM CRUZAMENTO DE VIAS SINALIZADO POR SEMÁFORO SOB A ÓTICA DA PESQUISA OPERACIONAL}

\section{Luciana Vasques Sanches Cardoso}

\section{João Carlos Teixeira dos Santos}

Resumo: Percebemos que o crescimento populacional tem impactado na qualidade de vida da população das metrópoles que vivem em regiões mais periféricas. $\mathrm{O}$ amplo debate sobre a questão da mobilidade urbana busca trazer luz a uma questão que vai muito além da oferta de serviços públicos de qualidade ou de condições de deslocamentos mais eficientes e sustentáveis, mas que, principalmente, está ligado ao modelo de desenvolvimento social, econômico e cultural que desejamos ver implementado no país, uma vez que traduz as relações dos indivíduos com o espaço e com outros indivíduos. A mobilidade urbana é um direito garantido pela Constituição Federal, uma via de equidade e acessibilidade social, por onde todos podem usufruir dos benefícios e das riquezas geradas pelo desenvolvimento econômico. É inclusive, o resultado do produto de um processo histórico das características culturais da sociedade, mas é principalmente, um dos princípios da cidadania. O presente trabalho, uma pesquisa exclusivamente bibliográfica, busca mostrar que os métodos e ferramentas da Pesquisa Operacional auxiliam nas decisões relacionadas à mobilidade urbana, gerando ações concretas e eficazes, com vistas à melhoria das condições de trânsito nos horários de pico na cidade de Sorocaba, na Praça Lions, cruzamento das Avenidas Dom Aguirre com Dr. Afonso Vergueiro. Ainda são investigadas soluções aplicadas à melhoria da mobilidade e da qualidade de vida no Brasil e no mundo. Valorizando esse estudo, propomos um novo olhar de como, a partir das soluções que já foram implantadas e obtiveram sucesso, podem ser aplicadas aos diversos cenários urbanos pelo país.

Palavras-chave: Pesquisa Operacional 1. Teoria das Filas 2. Mobilidade Urbana 3. 


\section{INTRODUÇÃO}

Quando falamos em trânsito nas metrópoles e grandes cidades, vemos que essa é uma questão de ordem social que tem ampla influência na mobilidade das pessoas. Ações de ir e vir motivadas por trabalho, escola, saúde, lazer, prestação de serviços e atividades logísticas têm se acentuado na medida em que os locais de moradia estão mais distantes dos espaços comerciais, empresariais e culturais.

A administração pública, organizações não governamentais e associações de classe são os principais envolvidos na busca pela melhoria no deslocamento urbano. E se entramos nessa questão, percebemos que existem impactos na qualidade do ar, no consumo de combustíveis, na saúde pública, no tempo de deslocamento, enfim, em gastos via políticas públicas e investimentos privados, para atenuar esses efeitos. Porém nos perguntamos: quais seriam as soluções para otimizar o fluxo de pessoas, maximizando a mobilidade e reduzindo a circulação de veículos nas vias urbanas, levando-se em conta, ainda, os horários de maior circulação?

Inicialmente, o processo de crescimento de uma cidade, mesmo que desordenado, não representava grande problema e, portanto, não foi acompanhado de estudos ou de análises da projeção do crescimento demográfico.

Segundo destaca Ascher (2010), "O crescimento das cidades esteve correlacionado, ao longo da história, com o desenvolvimento dos meios de transporte e armazenamento dos bens necessários para abastecer populações crescentes [...]".

Por volta do século XX, com o início do êxodo rural, atrelado e consolidado pela geração de empregos e renda na região urbana, ocorre a primeira fase da expansão territorial das cidades. Principal responsável pelo crescimento desordenado dos centros urbanos, agravado ainda pela falta de oferta de moradia e serviços públicos, muitas cidades experimentaram o efeito da conurbação, situação onde os limites dos municípios não estão facilmente definidos ou identificáveis por meio de marcos físico ou geográficos.

Já a concepção de mobilidade urbana sustentável é relativamente nova (BOARETO, 2003). Índices de velocidade média dos veículos, aspectos culturais de utilização de transporte particular e público, eventos culturais e climáticos entre outros, são hábitos particulares de uma cidade ou mesmo de um bairro, e geralmente não se reproduzem em outras regiões. Dessa forma, novas soluções devem ser provadas e evoluídas em ambiente virtual, para se obter o melhor em cada cruzamento e cidade.

O objetivo desse trabalho, uma pesquisa bibliográfica, foi identificar como as ferramentas e métodos da Pesquisa Operacional, quando voltadas para questões de tráfego nas grandes metrópoles, podem proporcionar melhoria na gestão, representada pela maior segurança e conforto aos usuários, redução dos acidentes de trânsito, do tempo de trajeto, das emissões de poluentes e dos custos.

Já o objetivo específico foi demonstrar que as ferramentas e métodos da Pesquisa Operacional são apropriados para a otimização do fluxo de pessoas, maximizando a mobilidade e reduzindo o tempo de circulação de veículos na região da Praça Lions, na cidade de Sorocaba, no cruzamento das Avenidas Dom Aguirre com Dr. Afonso Vergueiro, sob a ótica dos horários de maior circulação nessa via arterial.

\section{EMBASAMENTO TEÓRICO}

Nosso estudo é de cunho exclusivamente bibliográfico, o que nos permitiu buscar e analisar conhecimentos já construídos sobre o assunto e depois, reelaborá-los (LOPES; CERDAS, [20--]).

Para darmos conta de nossa proposta de pesquisa, fizemos a leitura de publicações e textos de teóricos que tratam de Mobilidade Urbana, Sustentabilidade, Trânsito nas Metrópoles, Pesquisa Operacional, Teoria das Filas e Cruzamentos de vias controlados por semáforos.

Enquanto as cidades ocupam 2\% da superfície do planeta, produzem até $70 \%$ da emissão de dióxido de carbono, o principal gás de efeito estufa. A população urbana representa metade da humanidade vivendo nas cidades.

Da mesma forma como questões de poluição sonora, visual, do ar, acidentes e congestionamentos são uma crítica realidade em países desenvolvidos, também são 
potenciais fontes de problemas para países em desenvolvimento.

Matéria do jornal O Globo (2016) relata:

[...]milhões de pessoas fugiram da fome e da miséria no campo apenas para encontrar um outro tipo de miséria nas grandes cidades. Segundo a ONU, hoje quase 900 milhões delas vivem em favelas espalhadas por todo mundo, com acesso restrito a serviços básicos, como saneamento e alimentação, e mais suscetíveis a problemas de saúde. Situação que tende a piorar, já que a perspectiva é de que esta população que vive nestes e outros tipos de assentamentos precários dobre até 2050.

Metrópoles são extensas áreas densamente povoadas e apresentam problemas de mobilidade e logística. Muitas cidades possuem formas complexas devido à má distribuição de empregos, de serviços públicos e de moradias, mas também como resultado de planejamento urbano e de transporte público, além da geografia e da malha viária. Fundadas há várias décadas ou séculos, possuem um sistema viário sem dimensionamento e que não atendem ao volume de tráfego.

Follador (2011) defende que a carência de integração entre política e gestão de transportes, além do uso e ocupação do solo e meio ambiente, têm estimulado a formação de um meio urbano insustentável. Segundo Faria e Lima (2016), "a facilidade oferecida pela existência de linhas de transporte coletivo pode motivar a implantação de novos loteamentos, aumentando o território urbanizado".

Os autores Wee, B. Van; Handy (2016), afirmam que $\mathrm{O}$ desenvolvimento, 0 planejamento e uso do solo devem objetivar a redução de viagens motorizadas, pois podem influenciar positivamente os usuários no uso de bicicleta ou deslocamentos a pé. Já Hrelja (2015), evidencia a necessidade de integrar o transporte sustentável ao transporte coletivo e público.

O automóvel permite inicialmente maior mobilidade, porém gera congestionamentos. Essa é uma problemática significativa na proposição de soluções por meio de políticas públicas (PENG; ZHU; SONG, 2008), incentivando $O$ transporte público, não motorizado e propondo alternativas ao transporte individual.
Para os autores Crozet; Lopez-Ruiz (2013), a mobilidade sustentável está ligada à mudança de comportamento dos usuários do transporte coletivo.

Sustentabilidade é fator preponderante quando se fala em mobilidade urbana, pois a crescente preocupação com o consumo de energia está diretamente ligada à racionalização do transporte público e a mobilidade (SUSNIENÉ, 2012).

Conforme afirma Kepaptsoglou et al. (2012), sistemas de transporte público têm despertado interesses em acadêmicos e desenvolvedores de sistemas de tráfego, pois soluções de mobilidade e funcionalidade das cidades estão integradas.

Integrante da área do conhecimento científico Management Science, a Pesquisa Operacional (PO), utilizando as operações lógico-científicas, auxilia no processo de tomada de decisão através da análise combinatória de grande número de variáveis do sistema em estudo.

Já para Desaulniers e Hickman (2007), a PO tem obtido sucesso em propor soluções voltadas ao transporte público e mobilidade. $O$ interesse da PO se justifica devido ao impacto que as soluções geram na qualidade de vida das pessoas e aos desafios propostos pela complexidade das operações.

A simulação, uma das ferramentas da $\mathrm{PO}$, é a reprodução de evento real durante espaço de tempo definido, em ambiente virtual. São alterados parâmetros de forma sistemática, prevendo impactos reais. Determinam-se regras e limites de referência. Valores subjetivos são processados pela ferramenta, pois na maior parte dos casos, limites e variáveis são exclusivos para cada situação de estudo.

Por outro lado, a Teoria das Filas é uma ferramenta para gerir e auxiliar decisões estratégicas, e pode ser utilizada para analisar questões relativas aos tempos de abertura e fechamento dos cruzamentos, otimizando o fluxo de pedestres e veículos.

De acordo com Taha (2008), o estudo de filas trata da quantificação do fenômeno da espera em filas, usando medidas representativas de desempenho como o comprimento médio de uma fila, o tempo médio da espera em fila e a média de utilização da instalação. Filas irão acontecer sempre que a demanda for superior à capacidade de fornecimento do serviço. 
Já Moreira (2010) afirma que, a Teoria das Filas são estudos por cálculos probabilísticos voltados aos fenômenos das filas. Nem sempre as filas se formam em função da capacidade de atendimento, porém, variabilidade entre chegadas e tempo no atendimento representam índices com grande influência sobre o sistema.

Villalobos (2017) afirma que, um dos modelos matemáticos de teoria das filas para cruzamento controlado por semáforo é o M/M/1. E reforça: "O uso da Teoria de Filas é uma ferramenta útil para avaliar a operacionalidade do sistema, tais como intensidade do tráfego no cruzamento, número médio e tempo de espera de veículos aguardando passar a luz verde e outras respostas que permitam informar se a interseção analisada está sob controle, se os resultados obtidos foram satisfatórios com a realidade observada no cruzamento analisado".

Zanchin; Araújo; Chin (2017) afirmam, com base nos conceitos da teoria das filas, que houve redução da ordem de $13 \%$ a $55 \%$ na fila máxima, além da redução no tempo de espera média da ordem de $29 \%$ a $67 \%$, em determinado cruzamento de 4 vias, após reformulação do ciclo semafórico, alterando as durações dos tempos de verde e vermelho. Para simplificar os cálculos foi considerado o tempo de amarelo como tempo de verde.

\section{DESENVOLVIMENTO DA TEMÁTICA}

Fundada por volta de 1654 como Povoado de Nossa Senhora da Ponte de Sorocaba, Sorocaba desenvolveu-se em diversos ciclos econômicos, do ouro ao tropeirismo, pecuária e indústria têxtil, culminando no forte período de industrialização de 1950 a 1980.

Censo de 2017 do Instituto Brasileiro de Geografia e Estatística (IBGE, 2017) estima a população do município em 659.871. Terceiro município mais populoso do interior paulista (menor que Grande São Paulo e Campinas) e quarto mercado consumidor do Estado, é considerada uma metrópole.

Ao longo dos últimos 12 anos, intensificaramse revitalizações, urbanização de ruas e avenidas, disponibilização de cinquenta quilômetros de ciclovias, preparando-se para uma expressiva circulação de veículos, inclusive de outras cidades, e efetuaram-se estudos de viabilidade para implantação de Ônibus de Trânsito Rápido - Bus Rapid Transit (BRT) nas vias de maior demanda por transporte público $(\mathrm{G} 1,2015)$.

Muitos problemas de mobilidade enfrentados vêm de características históricas e econômicas, com estratégicas equivocadas ou implantadas de forma tardia, gerando perda de oportunidades e a criação de verdadeiras lacunas de difícil resolução técnica ou economicamente inviáveis.

Corrobora com essa perspectiva Merlin e Choay (2005) ao afirmar que:

[...] A forma de uma cidade é sempre a forma de uma época da cidade: ela se apresenta ao mesmo tempo com uma espessura histórica, resultado de sua evolução no local, e como uma extensão geográfica, consequência de sua expansão no espaço [...].

A figura 1 ilustra o desenvolvimento da ocupação urbana de Sorocaba a partir da década de 50, e apresenta a projeção de crescimento para os próximos anos.

Figura 2 - Evolução da Ocupação Urbana de Sorocaba a partir de 1950 e Vetores de Crescimento

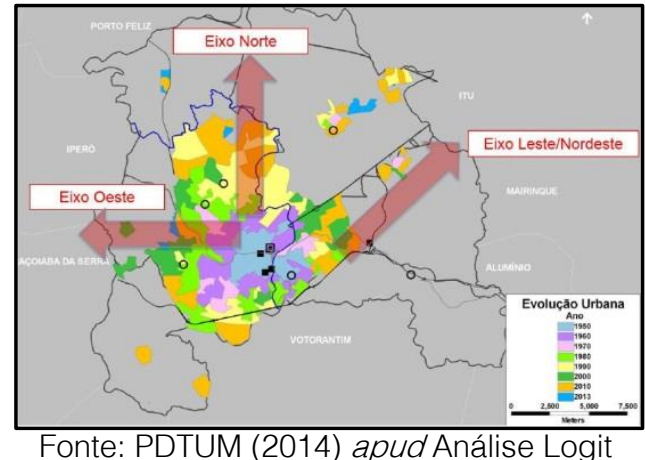


Segundo o Plano Diretor de Transporte Urbano e Mobilidade (PDTUM, 2014), a expansão contínua da ocupação do solo implica em políticas e ações que deem suporte à infraestrutura e demais serviços, conforme análise em seguida:

Eixo Norte: aceleração da ocupação das áreas adjacentes à Av. Itavuvu e ao Eixo Norte na direção tanto de Itu quanto de Porto Feliz devido à Toyota, suas auxiliares e o Parque Tecnológico de Sorocaba;

Eixo Oeste: expectativa no aumento de moradias populares e de médio padrão e implantação de Centro Hospitalar Regional;

Eixo Leste/Nordeste: implantação de indústrias e de loteamentos populares em direção à Itu e Mairinque. Contará com estímulo visando adensamento maior de moradias nas áreas próximas a Zona Industrial, reduzindo distâncias entre o emprego e o domicílio.
Eixo Sul: não configura vetor de crescimento, está consolidado e apresenta limites de expansão devido à conurbação com o Município de Votorantim.

\section{RESULTADOS E DISCUSSÃO}

Para Acker (2016), as escolhas do modo de viagem são uma rede complexa, e a forma como as pessoas vivem, trabalham ou interagem socialmente alteram as diretrizes e decisões relacionadas a definição do modo de deslocamento urbano.

Dados do PDTUM (2014) reforçam essa afirmação: "Em 11 anos a frota de Sorocaba aumentou $157 \%$ e a taxa de motorização (auto + moto) passou de 30 para 64 veículos por grupo de 100 habitantes, sendo o automóvel o maior responsável por esse efeito, conforme Figura 2. O aumento da frota e a evolução da taxa de motorização indicam um aumento significativo do número de viagens por veículo individual".

Figura 3 - Evolução da Frota de veículos em Sorocaba e Taxa de Motorização

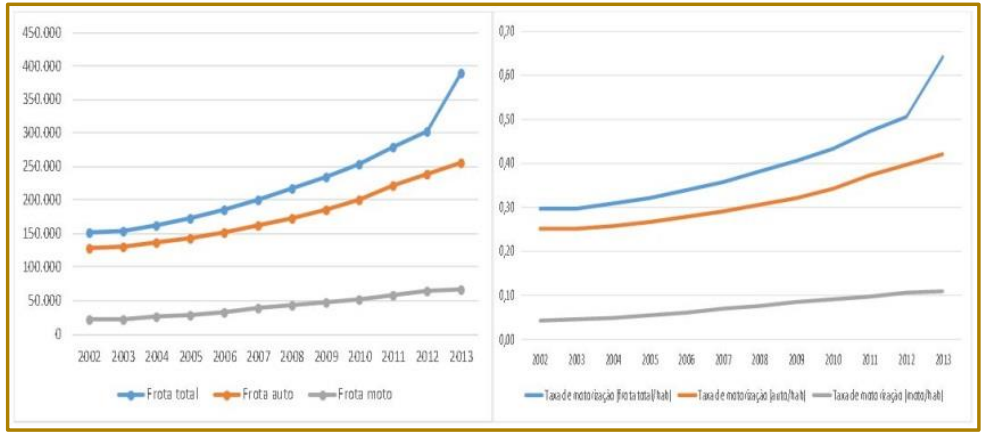

Fonte: PDTUM (2014) apud Denatran, 2013/Análise Logit

Por outro lado, Vargas e Sidotti (2008) afirma que a mobilidade está diretamente ligada ao contexto urbano, uma vez que "Mobilidade urbana é definida como a capacidade de deslocamento de pessoas e bens no espaço urbano para a realização de suas atividades cotidianas, num tempo considerado ideal, de modo confortável e seguro".

Dessa forma, o transporte público tem importante função na mobilidade e está associado a um modelo de desenvolvimento que, do ponto de vista da sustentabilidade, pode ou não estar alinhado com os princípios do viés sustentável.

O Plano de Mobilidade de Sorocaba foi idealizado pela Prefeitura de Sorocaba, através da Empresa de Desenvolvimento Urbano e Social de Sorocaba (URBES) entre os anos de 2012 e 2013. Segundo a Lei 12.587/12, artigo 4을 inciso II, mobilidade urbana é "condição em que se realizam os deslocamentos de pessoas e cargas no espaço urbano" (PDTUM, 2014). Nele estão as orientações para o município coordenar ações em transporte coletivo, individual e não motorizado.

O PDTUM (2014) do município de Sorocaba, está alinhado com as políticas, ações, princípios, diretrizes e objetivos da Lei Federal de Mobilidade Urbana, e cita: "Aproximadamente $68 \%$ das viagens realizadas são por meios motorizados (automóvel, táxi, moto ou ônibus) e 32\% das 
viagens são realizadas a pé ou de bicicleta. Das viagens motorizadas $62 \%$ são de modos individuais e $38 \%$ de modos coletivos (serviços de ônibus, incluindo fretado e rodoviário). Em relação aos modos não motorizados, cerca de $31 \%$ das viagens são realizadas a pé e menos de $1 \%$ das viagens são realizadas de bicicleta", conforme Figura 3.

Figura 4 - Divisão Modal de um dia útil em 2013

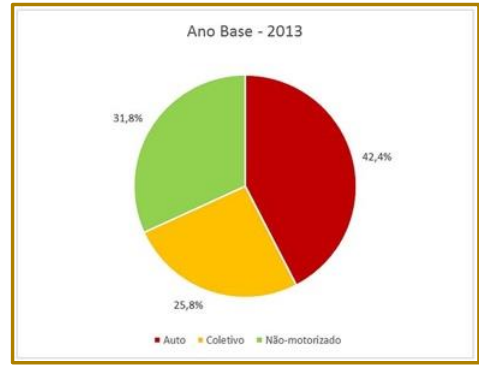

Fonte: PDTUM apudPODD

Sorocaba 2013/Análise Logit

Uma das variáveis que compõe a mobilidade sustentável é a eficiência no uso do espaço urbano. Esse indicador pode ser medido pelo cálculo da razão entre o espaço ocupado por pessoa e o espaço ocupado pelo veículo que as transporta.
De acordo Empresa Brasileira de Comunicação (EBC, 2017) Figura 4, temos que o transporte público por ônibus articulado, tem razão mais eficaz frente aos demais tipos de transporte urbano disponíveis atualmente.

Figura 5 - Mobilidade Sustentável

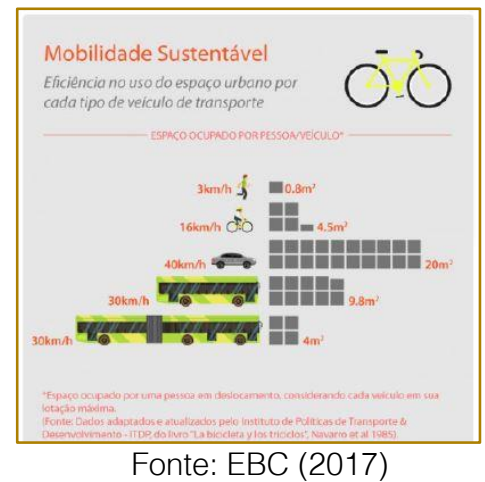

Já Kepaptsoglou et. al. (2012) aponta que mobilidade urbana, diferente de um pacote de padronizações aplicadas para buscar soluções, reivindica atitudes diferenciadas e inovadoras, abordagens e pontos de vista envolvendo questões como cidadania, humanização dos serviços e sustentabilidade. Políticas públicas estão atreladas à importância que governantes e planejadores dispensam sobre a relação entre mobilidade, às práticas de urbanismo e os impactos socioambientais, e têm fundamental papel na sustentabilidade.

Vemos com preocupação o disposto no PDTUM (2014) no que se refere ao eixo Leste/Nordeste, especificamente em relação ao estímulo e permissão de adensamento maior, uma das principais problemáticas para se manter a mobilidade.

Admitimos ainda a necessidade de nova postura dos órgãos públicos, privados e da sociedade, pois todos têm papel decisivo na busca e proposição de soluções que venham distribuir, de forma igualitária entre os integrantes da metrópole, os benefícios conquistados por essa visão transformadora.

Paralelamente, esses questionamentos e a busca por melhorias no sistema e na gestão devem ser práticas constantes, objetivando uma antecipação frente às crescentes 
demandas sociais e de desenvolvimento sustentável.

\section{CONSIDERAÇÕES FINAIS}

Nosso estudo teve como objetivo mostrar que as ferramentas e técnicas da Pesquisa Operacional, podem ser aplicadas para obter um sistema de tráfego mais homogêneo e funcional. Buscamos ainda, comprovar que essas técnicas são instrumentos organizacionais, estratégicos e de auxílio na tomada de decisão.

Vimos que é inegável o impacto do trânsito sobre os indicadores de saúde e qualidade de vida da população das metrópoles. Além de questões de poluição do meio ambiente, custos de saúde e seguridade social, estão tempo de percurso, custos logísticos e consumo de combustíveis.

Pesquisas apontam redução significativa nos índices de poluição e de acidentes, quando adotadas ações que privilegiam a mobilidade através do transporte público e não motorizado. Já nas cidades onde as ações e políticas públicas estiveram voltadas para uso do transporte individual, os problemas se intensificaram.

É certo que poderíamos mostrar muitos outros detalhes sobre de qual forma a versatilidade e recursos da Pesquisa Operacional auxiliam na tomada de decisão voltadas a mobilidade, assunto que estudamos, e que poderíamos tê-la examinado sob outros enfoques, o que legamos a outras pesquisas que virão.

É certo ainda que há, no Brasil, inúmeros desafios políticos, econômicos e sociais para otimizar a mobilidade urbana. Quanto ao uso de tecnologia para aprimoramento dos veículos, houve melhora significativa na eficiência em relação à queima de combustível fóssil ou na alteração da matriz energética motriz. Torná-los menos poluentes representa um grande passo para diminuir os impactos relativos à externalização dos prejuízos ambientais relacionados ao transporte individual.

No entanto, o espaço que cada veículo ocupa e necessita para circular, não poderá ser reduzido drasticamente a ponto de alterar as altas taxas de ocupação das malhas viárias. Cabe aos cidadãos inovar e em parceria com instituições de ensino e poder público, buscar soluções para o desenvolvimento sustentável e para a mobilidade urbana, culminando na melhoria da qualidade de vida.

Tecnologias presentes nos dispositivos móveis, a crescente disponibilização desses recursos nos veículos automotores, o aperfeiçoamento e expansão dessas tecnologias, podem ser ferramentas para simplificar a decisão dos usuários quanto à melhor opção de transporte, auxiliando na gestão da acessibilidade e disponibilidade do transporte público.

Por fim, vemos que questões relacionadas à mobilidade urbana ainda estarão sujeitas às mesmas deficiências, até que sejam revistos e alterados os modelos adotados, na maior parte dos municípios, de mobilidade urbana que, com raras exceções, têm privilegiado o transporte motorizado individual em detrimento ao transporte coletivo ou ao não motorizado.

\section{REFERÊNCIAS}

[1]. ACKER, Veronique. VAN; GOODWIN, Phil.; WITLOX, Frank. Key research themas on travel behavior, lifestyle, and sustainable urban mobility. International Journal of Sustainable Transportation, V.10, n.1, p.25-32, 2016. Disponível em: < https://www.researchgate.net/publication/28580200 5_Key_Research_Themes_on_

[2]. Travel_Behaviour_Lifestyle_and_Sustainab le_Urban_Mobility>. Acesso em: 19 out. 2017.

[3]. ASCHER, F. Os novos princípios do urbanismo. Coleção RG bolso. São Paulo: Romano Guerra, 2010.

[4]. BOARETO, R. A mobilidade urbana sustentável. Revista dos Transportes Públicos, n.100 - ANTP, São Paulo, 2003.

[5]. CROZET, P. Y.; LOPEZ-RUIZ, H. G. Macromotives and microbehaviors: Climate change constraints and passenger mobility scenarios for France. Transport Policy, v. 29, p. 294-302, 2013. ISSN 0967-070X. Elsevier. Disponível em: < https://doi.org/10.1016/j.tranpol.2012.07.002>. Acesso em: 10 set. 2017

[6]. DESAULNIERS, G.; HICKMAN, M. D. Handbook in OR \& MS. v.14, cap.2, Elsevier, 2007.

[7]. EBC - Empresa Brasil de Comunicação. Mobilidade urbana: um desafio para as cidades 
brasileiras. 2017. Disponível em: < http://www.ebc.com.br/especiais/mobilidadesustentavel>. Acesso em: 08 nov. 2017.

[8]. FARIA, Helena Mendonça; LIMA, Cristina de Araújo; Andar a pé mobilidade urbana e sustentabilidade nas regiões metropolitanas brasileiras. In: RUA [online]. no. 22. Volume 1, p. 125-149 - ISSN 1413-2109 - Junho/2016. Consultada no Portal Labeurb - Revista do Laboratório de Estudos Urbanos do Núcleo de Desenvolvimento da Criatividade. Disponível em: $<$ http://www.labeurb.unicamp.br/rua/>. Acesso em: 26 out. 2017.

[9]. FOLLADOR, Débora Pinto. Constituição do plano diretor de transporte e da mobilidade: estudo comparativo Belo Horizonte e Curitiba. PUC-PR, dissertação mestrado, Curitiba- PR 2011.

[10]. G1. Obras para implantação do BRT em Sorocaba. Disponível em: <http://g1.globo.com/sao-paulo/sorocabajundiai/noticia/2015/01/obras-para-implantacao-dobrt-em-sorocaba-devem-comecar-em-

agosto.html>. Acesso em: 20 out. 2017.

[11]. HRELJA, R. Integrating transport and landuse planning? How steering cultures in local authorities affect implementation of integrated public transport and land-use planning. Transportation Research Part A: Policy and Practice, v. 74, p. 1-13, 2015. ISSN 0965-8564. Elsevier Ltd. Disponível em: < https://doi.org/10.1016/j.tra.2015.01.003>. Acesso em: 02 set. 2017

[12]. IBGE - INSTITUTO BRASILEIRO DE GEOGRAFIA E ESTATÍSTICAS. Censo Demográfico, 2017. Disponível em: <https://cidades.ibge.gov.br/brasil/sp/sorocaba/pa norama>. Acesso em: 22 set. 2017.

[13]. KEPAPTSOGLOU, K.; MEERSCHAERT, V.; NEERGAARD, K.; PAPADIMITRIOU, S.; RYE, T.; SCHREMSER, R.; VLEUGELS, I. Quality management in mobility management: a scheme for supporting sustainable transportation cities. International Journal of Sustainable Transportation. v.6, n.1, p.235-256, 2012

[14]. LOPES, Eduarda Escila Ferreira; CERDAS, Luciene (Ors.). Metodologia do trabalho científico. Araraquara: Centro Universitário de Araraquara UNIARA/Núcleo de Educação a Distância - NEAD, [20--]. Disponível em: $<$ http://ead.uniaraonline.com.br/moodle/mod/resour ce/view. php?inpopup=true\&id=38218 >. Acesso em: 21 ago. 2017.

[15]. MERLIN, Pierre; CHOAY, Françoise Dictionnaire de l'urbanisme et de l'aménagement. Paris: Presses Universitaires de France, 2005, (1 1 ed. 1988).
[16]. MOREIRA, D. A. Pesquisa Operacional: Curso Introdutório. 3. ed. ver. eatu. São Paulo: Cengage Learning, 2010. 356 p.

[17]. O GLOBO. Conferência Habitat III, da ONU: cidades são a chave para o desenvolvimento sustentável. Disponível em: $<$ https://oglobo.globo.com/sociedade/populacaourbana-global-passou-de-38-55-do-total-em-40anos-20319443>. Acesso em: 03 nov. 2017

[18]. ONU. Departamento de Informações Públicas das Nações Unidas. RIO+20. Rio de Janeiro, Brasil. Junho 2012. Disponível em:< http://www.onu.org.br/rio20/cidades.pdf>. Acesso em: 03 nov. 2017.

[19]. PDTUM. Plano Diretor de Transporte Urbano e Mobilidade, 2014. Disponível em: < https://www.urbes.com.br/pdtum>. Acesso em: 08 nov. 2017

[20]. PENG, Z.; ZHU, Y.; SONG, S. Mobility of the Chinese urban poor: a case study of Hefei City. The Chinese Economy, v.41, n.1, p.36-57, 2008

[21]. SUSNIENÉ, D. Quality approach to the sustainability of public transport. Transport. v. 27, n. 1, p.102-110, 2012

[22]. TAHA, Hamdy A. Pesquisa Operacional. 8ed. São Paulo, Pearson, 2008.

[23]. URBES. Empresa de Desenvolvimento Urbano e Social de Sorocaba. Ranking das vias com maior incidência de acidentes de trânsito. 2017. Disponível em: < https://www.urbes.com.br/incidencia-vias>. Acesso em: 21 ago. 2017.

[24]. VARGAS, H.C.; SIDOTTI, C. Mobilidade e Adensamento Urbano. Uma publicação da Associação Viva o Centro. Ano XII, n.47, p.8 e 9, 2008 .

[25]. VILLALOBOS, Luz Delicia Castilho. Uso da teoria de filas na avaliação da operacionalidade de uma interseção sinalizada por semáforo. UTFPR. Paraná, 2017

[26]. WEE, Bert van; HANDY, Susan. International Journal of Sustainable Transportation: Key research themes on urban space, scale, and sustainable urban mobility. V. 10, n. 1, p. 18-24, $2016 . \quad$ Disponível em: <http://www.tandfonline.com/doi/full/ 10.1080/15568318.2013.820998>. Acesso em: 20 set. 2017

[27]. ZANCHIN, Marlon Muriel; ARAÚJO, Renato Gonçalves Vieira; CHIN, Shih Yung. Reprogramação semafórica de um cruzamento com base na teoria de filas e métodos estocásticos e simulação. Disponível em < http://www.aprepro.org.br/conbrepro/2017/down.ph p?id=2977\&q=1 > . Acesso em: 28 jan 2018. 


\section{Bapítulo 15}

\section{METODOLOGIA ATIVA COMO FERRAMENTA DE ENSINO E APRENDIZAGEM EM CURSOS DE LOGÍSTICA}

\section{Juliana Ferreira de Vales}

Julio Cesar Ferreira dos Passos

José Carlos Redaelli

Orlando Fontes Lima Junior

Resumo: A mudança do perfil comportamental dos alunos junto com uma maior disponibilidade de conteúdos demanda maior participação ativa no processo de aprendizagem. A questão principal deste trabalho é saber como utilizar as metodologias ativas no ensino de disciplinas como a logística. Na literatura existem poucas informações específicas do uso de metodologias ativas em logística. Objetivo deste artigo é apresentar e analisar aplicações de três técnicas de metodologia ativa (GO-GV, Grupo de observação e de verificação, GO Grupo de oposição e Flipped Classroom, aula invertida) em situações reais no ensino da logística. Seguindo a metodologia de estudo de casos múltiplos foram realizadas três experimentos em uma disciplina de serviços logísticos no curso da faculdade de engenharia civil, FEC-UNICAMP. As técnicas mostraram-se muito adequadas ao uso no ensino de logística e abre oportunidade para novas aplicações quer seja em situações presenciais quanto virtuais ou mistas

Palavras-chave: Metodologia ativa, Logística, Intervenções, Aprendizagem, Ensino. 


\section{INTRODUÇÃO}

Nas últimas décadas, houveram mudanças significativas no perfil do aluno. A instituição de ensino também mudou e sobrevive em um contexto socioeconômico que impõe expectativas de desempenho cada vez mais elevadas. Os professores já aceitam a situação que os alunos estão cada vez menos interessados pelos estudos e reconhecendo menos a autoridade do professor (SANTOS; SOARES,2011). No Brasil convivemos com diversos contextos educacionais que vão desde instituições onde os alunos ocupam grande parte do seu tempo copiando texto até instituições que disponibilizam para os seus professores e alunos os recursos mais modernos da informação e comunicação (NEVES,2014).

Para reduzir tais falhas, as instituições vêm adotando novas formas de ensinoaprendizagem na perspectiva de integrar a teoria e a prática, com destaque para as metodologias ativas de aprendizagem. Estas "têm o potencial de despertar a curiosidade, à medida que os alunos se inserem na teorização e trazem elementos novos, ainda não considerados nas aulas ou na própria perspectiva do professor" (BERBEL, 2011, p.28).

Atualmente as metodologias ativas vêm contribuir para formar profissionais como sujeitos sociais, desenvolvendo competências éticas, políticas técnicas, potencializando o uso do conhecimento, do raciocínio crítico e analítico associado à responsabilidade $e$ sensibilidade para as questões da vida e da sociedade.

O objetivo do trabalho é analisar o uso da aprendizagem ativa no ensino da logística através do uso de 3 técnicas de metodologia ativa (GO-GV, Grupo de Observação e de Verificação, GO, Grupo de Oposição e Flipped Classroom, aula invertida).

Para desenvolver a análise do uso das metodologias ativas foi realizado um estudo de caso em disciplina de logística envolvendo alunos de graduação e pós-graduação do curso de engenharia civil da FEC-Unicamp.

\section{METODOLOGIAS ATIVAS NA LITERATURA}

As metodologias precisam acompanhar os objetivos pretendidos. Se o objetivo é que o aluno seja proativo, precisam-se adotar metodologias em que os alunos se envolvam em atividades mais complexas para que tenham que tomar decisões e avaliar resultados. Alguns teóricos como Dewey (1950), Freire (2009), Rogers (1973), Novack (1999) entre outros, enfatizam a importância de superar a educação bancária, tradicional e focar a aprendizagem no aluno, envolvendoo, motivando-o e dialogando com ele.

Porém por muitos anos, o modelo tradicional de educação teve como foco, o ensino, com o poder do professor sobre o estudante (NAGAI; IZEKI,2013). Por este motivo, devese abandonar os métodos tradicionais de transmissão do conhecimento atual e o professor assumir um papel de facilitador e técnico no processo de aprendizagem.

Aprendizagem ativa ocorre quando o aluno interage com o assunto em estudo- ouvindo, falando, perguntando, discutindo, fazendo e ensinando - sendo estimulado a construir o conhecimento ao invés de recebê-lo de forma passiva do professor. Em um ambiente de aprendizagem ativa, o professor atua como orientador, supervisor, facilitador do processo de aprendizagem e não apenas como fonte única de informação e conhecimento (BARBOSA; MOURA,2013, p.55).

Assim em oposição, a aprendizagem passiva e bancária, o aluno assume uma posição mais ativa, na qual ele resolve problemas, desenvolve projetos e com isso cria oportunidades para a construção do conhecimento. A seguir serão apresentadas 3 intervenções aplicadas na disciplina de logística do curso de pós-graduação em engenharia, com os seus objetivos e resultados.

Há uma grande necessidade de formar professores que aprendam a pensar, a correlacionar teoria e prática, a buscar, de modo criativo e adequado às necessidades da sociedade, na resolução de problema do cotidiano. Além de tudo, professores aptos a agregar para si transformações em suas práticas pedagógicas.

Desta forma Paulo Freire (2006), explica que a metodologia ativa é uma concepção educativa que estimula processos construtivos de ação-reflexão-ação, ou seja, o estudante tem uma postura ativa em relação ao seu aprendizado, em uma situação prática, por meio de problemas que estimulem sua ação, permitindo que realize pesquisa e descobrindo soluções aplicáveis a realidade. 
Faz-se necessário o desenvolvimento do corpo discente das instituições de ensino, também no uso da tecnologia de informação e comunicação (TIC). Esta possibilita o acesso a ferramentas que de uma forma autorregulada podem-se buscar conhecimentos no mundo virtual, como também interagir com alunos e mediadores de cursos.

Estas ferramentas possibilitam a autonomia dos alunos quanto a aprendizagem, promovendo atitudes proativas e eficientes na procura de conhecimento para a formação. Sendo a interação com professores, tutores e colegas de sala de aula uma ação relevante na aprendizagem, os alunos introvertidos encontram um espaço livre no ambiente de Ensino à Distância $(\mathrm{EaD})$ para se expressarem.
A modalidade EaD tem se mostrado uma poderosa ferramenta de inclusão social. Neste sentido, é também uma alternativa para aqueles que precisam conciliar os estudos com outras tarefas. Muitas questões e discussões são ainda levantados quanto ao uso de jogos eletrônicos voltados para o desenvolvimento cognitivo e aprendizado dos alunos.

\section{METODOLOGIA}

Para este trabalho a metodologia utilizada foi a de estudo de casos múltiplos. Segundo Yin (2009) o estudo de caso é útil para investigar novos conceitos, bem como verificar como são aplicados e utilizados na prática elementos de uma teoria. A Figura 1 ilustra as etapas do método bem como os passos a serem realizados durante as aulas.

Figura 1 - Etapas do método estudo de caso aplicado.

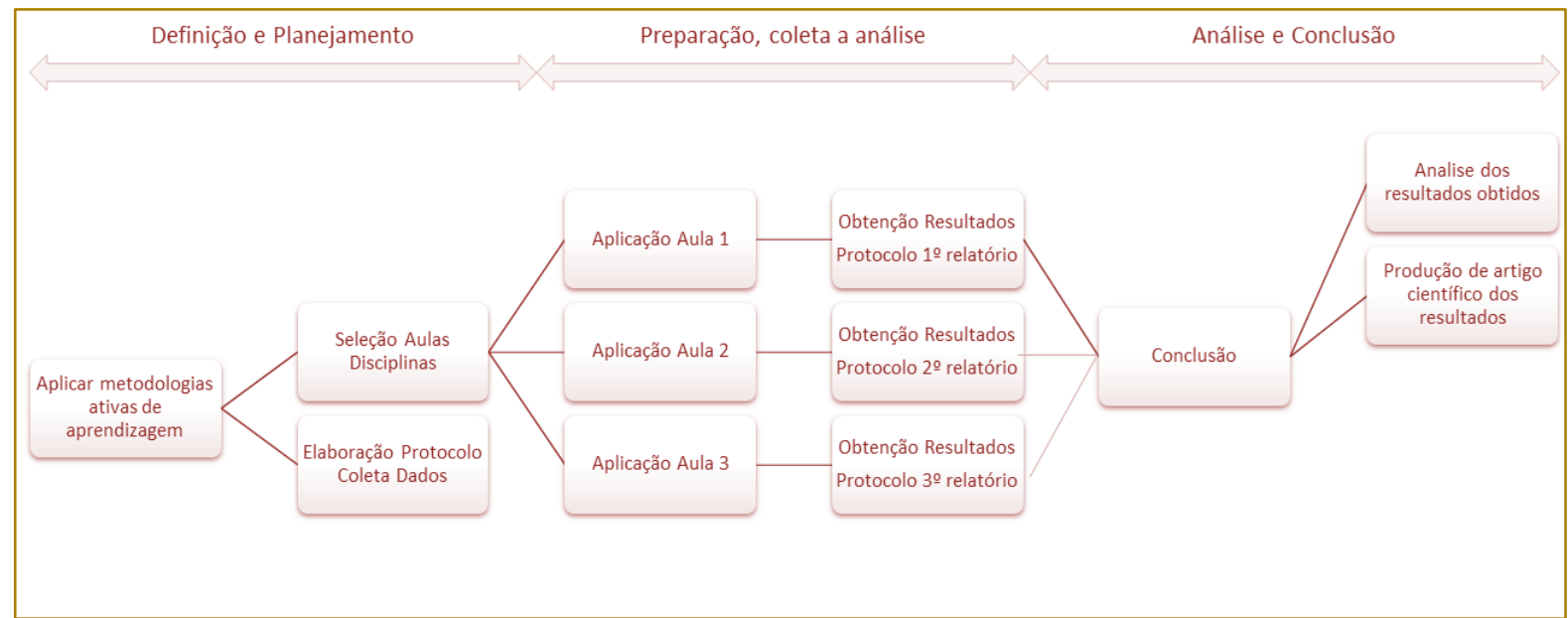

Fonte: Yin (2009).

As etapas de definição e planejamento direcionara a pesquisa para aplicar as metodologias ativas de aprendizagem, a seleção da disciplina e as aulas bem como a elaboração dos protocolos para coleta de dados.

$\mathrm{Na}$ etapa de preparação e coleta de dados, foram realizadas as aplicações nas aulas selecionadas que contaram também com a obtenção dos resultados observados das metodologias ativas.

Finalmente, na etapa de análise e conclusão, foram realizados estudos dos resultados obtidos das aplicações e a produção do presente artigo científico.
Para aplicação do método foram desenvolvidos protocolos de aplicação. Para Yin (2005) o protocolo de um estudo de caso é mais do que um instrumento. O protocolo contém o instrumento, mas também contém os procedimentos e regras gerais que deveriam ser seguidas ao usar os instrumentos.

A aplicação do estudo de caso foi realizada nas turmas da disciplina "Fundamentos de Serviços Logísticos" na pós-graduação do curso de Engenharia Civil da Universidade Estadual de Campinas (FEC-UNICAMP). Foram planejadas e realizadas 3 intervenções 
junto às turmas com teorias relacionadas aos conceitos de logística e transportes.

\section{APLICAÇÃO PRÁTICA}

$\mathrm{Na}$ aplicação prática foram realizadas 3 intervenções presenciais durante as aulas no curso de pós-graduação de Engenharia Civil disciplina Fundamentos Logísticos.
A primeira intervenção ocorreu na primeira aula, com o tema: "What is supply chain?'. Utilizou-se a dinâmica "Flipped Classroom" (sala de aula invertida), onde o objetivo da dinâmica seria favorecer o trabalho em grupo (alunos ainda não se conheciam), sedimentar os conhecimentos estudados em sala e testar se o texto enviado antecipadamente, foi lido pelos alunos. Nesta aplicação foi utilizado o Protocolo 1 apresentado na Figura 2.

Figura 2 - Protocolo de aplicação da primeira aula.

\begin{tabular}{|c|c|}
\hline \multicolumn{2}{|c|}{ Protocolo de Direcionamento - Atividade Pedagógica } \\
\hline \multicolumn{2}{|c|}{ Informaçōes Preliminares } \\
\hline Dinâmica: Flipped Classroom & Modalidade: Presencial \\
\hline Recursos Utilizados: 1 texto (inglés) & $\begin{array}{l}\text { Quantidade Alunos presentes: } 33 \\
\text { Quantidade alunos participaram: } 27\end{array}$ \\
\hline Disciplina: Fundamentos de Servicos Logísticos & Tema Aula: What is Supply Chain \\
\hline Data de Aplicaçăo: 16/03/2017 & $\begin{array}{l}\text { Materiais Utilizados: } 1 \text { texto no idioma inglés de } 4 \\
\text { parágrafos, } 5 \text { questöes. }\end{array}$ \\
\hline \multicolumn{2}{|l|}{ Objetivos } \\
\hline \multicolumn{2}{|c|}{$\begin{array}{l}\text { - Favorecer o trabalho em grupo entre os estudantes. } \\
\text { - Sedimentar os conhecimentos estudados na aula. } \\
\text { - Testar se o texto enviado antecipadamente foi lido. }\end{array}$} \\
\hline \multicolumn{2}{|l|}{ Desenvolvimento } \\
\hline \multicolumn{2}{|c|}{$\begin{array}{l}1^{\circ} \text {. Săo enviados aos alunos, via drive ou e-mail, com antecedéncia de } 48 \text { horas o assunto da aula } \\
\text { contendo: } 1 \text { texto no idioma inglês de } 4 \text { parágrafos; } \\
2^{\circ} \text {. Com o assunto previamente estudado, os alunos são separados em grupos de no máximo } 5 \\
\text { alunos; } \\
3^{\circ} \text {. Com os grupos estabelecidos, aplicam-se das } 5 \text { questões, somente a pergunta de } 1 \text { a } 4 \text { (deixando } \\
\text { a } 5^{2} \text { sem resposta), a respeito dos materiais previamente enviados; } \\
4^{\circ} \text {. Em seus grupos os alunos discutem por } 15 \text { minutos o que entenderam do conteúdo e respondem } \\
\text { as } 4 \text { questões; } \\
5^{\circ} \text {. Após as discussões e respostas os alunos de cada grupo são nomeados em número de } 1 \text { a } 5 \text {. } \\
6^{\circ} \text {. Com a nomenclatura estipulada os alunos são novamente divididos em novos grupos de seus } \\
\text { respectivos números; } \\
7^{\circ} \text {. Em seus novos grupos, os alunos discutem novamente e respondem a } 5^{2} \text { pergunta; } \\
8^{\circ} \text {. Ao final, os alunos realizam a devolução das questões respondidas. } \\
9^{\circ} \text {. Avaliação: solicitar aos participantes que expressem seus comentários sobre a dinâmica. } 0 \text { que } \\
\text { acharam da dinâmica, seus objetivos, etc. }\end{array}$} \\
\hline \multicolumn{2}{|l|}{ Referências } \\
\hline \multicolumn{2}{|c|}{$\begin{array}{l}\text { Bergmann, J. \& Sams, A. (2012). Flip Your Classroom: Reach Every Student in Every Class Every Day. } \\
\text { International Society for Technology in Education. }\end{array}$} \\
\hline \multicolumn{2}{|c|}{$\begin{array}{l}\text { Bergmann, J. \& Sams, A (2016) Sala de Aula Invertida - Uma Metodologia Ativa de Aprendizagem', } \\
\text { traducäo de Afonso Celso da Cunha: Editora LTC. }\end{array}$} \\
\hline
\end{tabular}

Fonte: Os autores (2017).

A segunda intervenção foi aplicado o com o tema: "Supply Chain performance: Achieving strategic fit and scope", que utilizou a dinâmica GO, Grupo de Observação, Grupo de Verbalização. O grupo que estava posicionado em verbalizar deveria retomar os pontos importantes da matéria disponibilizada e o grupo de observação somente se manifestaria caso algo não estivesse correto ou faltando algo. Nesta aplicação foi utilizado o Protocolo 2 apresentado na Figura 3. 
Figura 3 - Protocolo de aplicação da segunda aula.

\begin{tabular}{|c|c|}
\hline \multicolumn{2}{|c|}{ Protocolo de Direcionamento - Atividade Pedagógica } \\
\hline \multicolumn{2}{|c|}{ Informaçỏes Preliminares } \\
\hline Dinämica: GOVGV (observaçäalverbalizaçäo) & Modalidade: Presencial \\
\hline $\begin{array}{l}\text { Recursos Utilizados (TIC): Bloco de Notas, } \\
\text { Cadernos, Canetas, Lousa. }\end{array}$ & Quantidade Alunos: 40 \\
\hline $\begin{array}{l}\text { Discipling: Fundamentos de Servipas } \\
\text { Logísticos }\end{array}$ & $\begin{array}{l}\text { Tema Aula: SUPPLY CHAIN } \\
\text { PERFORMANCE: ACHIEVING STRATEGIC } \\
\text { FIT AND SCOPE }\end{array}$ \\
\hline Data de Aplicaçäo: 23/03/2017 & $\begin{array}{l}\text { Materiais Utilizados: Video Aula Chopra } 10 \\
\text { questỗes no formato de Quis. }\end{array}$ \\
\hline
\end{tabular}

Objetivos

- Desenvolver a capacidade de ouvir o outro.

- Desenvolver a capacidade de manifestar-se na vida.

- Contribuir para a ampliação do conhecimento do outro.

- Exercitar a elaboração de síntese.

Desenvolvimento

1. Dividir a turma em dois subgrupos, que formaräo dois círculos. O círculo interno será o da verbalização, que tem como tarefa, a discussăo de um tema proposto. O círculo extemo será o de observaç̃o. A ele cabe a tarefa de observar o processo de discussão e o conteúdo da mesma;

2. Coordenador lança uma pergunta sobre o tema (capaz de provocar uma discussão). Somente o grupo interno poderá responder, discutindo o assunto.

3. Durante a discussão, o grupo de observaçẫo, apenas registra ideias esquecidas pelo grupo de verbalização, anota dúvidas, e outros pontos que gostariam de falar.

4. Após 10 minutos de discussão, inverter os grupos.

5. Coordenador formula a mesma questão ou outra para que o grupo, de observaçäo agora na posiçãá de verbalizaçâo, possa expressar ideias, completar ideias do grupo anterior. exemplificar, etc.

B. Após 10 minutos formar uma grande círculo:

a) Fazer uma síntese dos pontos discutidos;

b) Fazer uma avaliação.

7. Observação:

- E responsabilidade do coordenador cuidar de:

1- Formular bem as perguntas:

2- Ficar atento para que todos participem;

3- fazer com que o grupo de verbalizaçäo se expresse de maneira clara para que todos possam ouvir suas opiniões;

4- fazer com que o grupo de observação fique absolutamente calado durante a discussão do grupo de dentro;

5- Marcar o tempo e determinar a troca de posiçốes;

Q- Abrir o debate final no grupão;

7- Fazer a síntese final da discussão.

\section{Referências}

Masetto, Marcos Tarcisio (2012). Competēncia pedagógica do professor universitärio. Säo Paulo, Summs

Fonte: Os autores (2017).

A terceira intervenção foi aplicado o tema: "Networking Design in the Supply Chain designing distribution network and Balanced Score Card". Nesta aula foi utilizada a dinâmica "Grupo de Oposição" onde a sala foi dividida em dois grupos, onde o primeiro grupo deveria contrapor e o segundo defender a metodologia. Nesta aplicação foi utilizado o Protocolo 3 apresentado na Figura 4. 
Figura 4 - Protocolo de aplicação da terceira aula.

\begin{tabular}{|c|c|}
\hline \multicolumn{2}{|c|}{ Protocolo de Direcionamento - Atividade Pedagógica } \\
\hline \multicolumn{2}{|c|}{ Informaçōes Preliminares } \\
\hline Dinâmica: Grupo de Oposiçẵo & Modalidade: Presencial \\
\hline $\begin{array}{l}\text { Recursos Utilizados (TIC): } 1 \text { Computador, } 1 \\
\text { Câmera, Software YouTube ao Vivo (Hangouts), } \\
\text { Software. }\end{array}$ & Quantidade Alunos: 40 \\
\hline Disciplina: Fundamentos de Serviços Logísticos & $\begin{array}{l}\text { Tema Aula: Network Design in the Supply Chain . } \\
\text { Designing Distribution Network and The Balanced } \\
\text { Scorecard }\end{array}$ \\
\hline Data de Aplicação: 30/03/2017 & $\begin{array}{l}\text { Materiais Utilizados: } 1 \text { vídeo Youtube (Autor } \\
\text { Robert S. Kaplan). }\end{array}$ \\
\hline
\end{tabular}

Objetivos

- Desenvolver a capacidade de argumentar,

- Desenvolver a capacidade de debater e produzir argumentos;

- Participar direta ou indiretamente de uma discussäo:

- Exercitar a elaboração de defender ou atacar determinadas teorias e posições;

- Verificar as reaçóes dos alunos em posiçöes inversas.

Desenvolvimento

10. São enviados aos alunos, via e-mail, com antecedência de 3 dias o link da vídeo aula do autor Robert S. Kaplan: "The Balanced Scorecard";

$2^{\circ}$. Com o assunto previamente estudado, os alunos são orientados a se dividirem em 2 grupos;

$3^{\circ}$. Os mediadores determinam um grupo para defender a metodologia BSC e outro grupo para atacar (demonstrar desvantagens) da metodologia BSC; Ao grupo que defenderá a metodologia BSC será orientado a construir argumentos para defesa do assunto; Ao grupo que atacará a metodologia BSC será orientado a construir argumentos para criticar o sssunto;

$4^{0}$. Será concedido a ambos os grupos o tempo de 10 minutos para construir argumentos e ataques da metodologia BSC;

$5^{\circ}$. Será concedido aos grupos o tempo de 10 minutos para debate entre defesa e ataque;

$6^{\circ}$. Após as discussões seräo invertidos as posições de defesa e ataque da metodologia BSC (Quem atacava, defenderá e quem defendia stacará):

$7^{\circ}$. Será concedido 10 minutos para a atividade de debate;

$8^{\circ}$. Aplicar perguntas que levem 05 grupos a refletirem sobre argumentação, defesa e ataque a determinada opiniâo.

$9^{\circ}$. Acatar e promover reflexão sobre a dinâmica, pontos positivos, negativos e sugestão de melhorias.

\section{Referèncias}

Bergmann, J. \& Sams, A. (2012). Flip Your Classroom: Reach Every Student in Every Class Every Day. International Society for Technology in Education.

Masetto, Marcos Tarciso - Competência Pedagógica do Professor Universitário 2012. Editora SUMMUS.

Fonte: Os autores (2017).

\section{RESULTADOS OBTIDOS}

$\mathrm{Na}$ aplicação da primeira intervenção, dos 33 alunos presentes, 27 alunos responderam os questionários, representando $81 \%$ dos alunos que efetuaram a dinâmica. Dos 27 alunos que responderam o questionário, 17 alunos responderam que realizaram a leitura do texto antecipadamente e 10 alunos responderam que não leram. Isso representa que 62,96\% efetuaram a leitura. Com esse resultado, foi verificado que a maior parte dos alunos efetuou a leitura do texto antecipadamente e isso representa uma parcela boa. Sobre as perguntas sobre o conhecimento obtido através do texto e da explicação feita em sala, grande parte dos alunos elogiaram essa metodologia de ensino e aprendizagem relatando que não foram surpreendidos pela aula, visto que eles já sabiam o conteúdo a ser estudado. Desta forma essa metodologia 
"Flipped Classroom" foi validada com sucesso.

$\mathrm{Na}$ segunda intervenção estiveram presentes 28 alunos (presencial) com a sala dividida em 2 grupos. O grupo menor, GV, Grupo de Verbalização, foi o grupo que ficou no meio da sala e teve como tarefa a discussão do tema proposto pelo coordenador em um tempo de 15 minutos. Todos os alunos participantes tiveram que expor as suas opiniões em relação ao tema proposto. A discussão ocorreu muito bem, e os próprios integrantes se ajudavam. O grupo que estava maior, GO, Grupo de Observação, apenas observou e anotou o que gostaria de falar ou - que não ficou claro. Depois de terem passado 15 minutos, a pergunta foi feita para - Grupo de Observação, questionando se faltou alguma coisa o se eles gostariam de complementar com outras perguntas. Esse grupo também foi bem participativo. Foi estipulado mais 15 minutos nesse formato. Após o tempo determinado, o coordenador uniu os dois grupos para fazer a discussão final, onde cada um pode expor as suas dúvidas e comentários, e houve um fechamento pelo coordenador verificando se ainda restavam dúvidas. Foi perguntado se o grupo gostou da dinâmica e todos relataram que sim, significando que a imersão sobre o tema é maior e a compreensão também. Desta forma essa metodologia (GO-GV) foi validada com sucesso.

Na aplicação da técnica Grupo de Oposição, estiveram presentes na sala um total de 20 alunos. Foram divididos em dois grupos de 10 alunos. Para um grupo foi determinado que este defenderia a metodologia BSC e para o outro grupo foi determinado que eles atacariam a metodologia. A mediação orientou que eles se preparassem por cinco minutos discutindo as ideias antes do início do debate. Após este tempo iniciaram os debates. Cada grupo teve 10 minutos para primeiramente defender as suas ideias e depois mostrar as vantagens e desvantagens da metodologia BSC, que acabaram usando mais 10 minutos. Após esse determinado tempo foram invertidas as posições de defesa e ataque e a mediação ocorreu em mais 10 minutos. Depois desse tempo a mediação finalizou a dinâmica levantando os aspectos positivos e negativos. Quando questionados como foi a dinâmica, os alunos deram respostas muito positiva. Os relatos foram sobre a dificuldade de encontrarem as desvantagens de uma metodologia que todos acreditam. Eles também relatam a dificuldade de mudarem de opinião rapidamente.

\section{CONCLUSÕES}

Segundo Masetto (2012) as pessoas aprendem na relação com o outro e com o mundo. Algumas técnicas facilitam muito a interação do grupo e o processo de aprendizagem. As 3 técnicas de metodologia ativa abordadas neste artigo, GO-GV, Grupo de Observação e de Verificação, GO, Grupo de Oposição e Flipped Classroom aula invertida, confirmam esta afirmação.

Durante aplicação das técnicas, ficou claro que as atividades desenvolvidas em grupo tem relação totalmente diferente de atividades desenvolvidas individualmente. Já as atividades pedagógicas coletivas trazem contribuições mais significativas do que as individuais.

Muitos são os exemplos de atividades pedagógicas coletivas: seminário, excursões, atividades em grupos das mais diversas, como GO-GV, painel integrado, grupos de oposição, pequenos grupos de formular questões ou solucionar casos, projetos.

Neste estudo, as 3 técnicas utilizadas mostraram-se bastante eficientes no processo de aprendizagem de conteúdos na área de logística. $\mathrm{Na}$ aplicação da metodologia Flipped Classroom ou aula invertida, a transmissão de conteúdo torna-se mais dinâmica e explora bem o trabalho em grupo, pois o aluno torna-se mais ativo no processo de aprendizagem obtendo conhecimento prévio com o material disponibilizado para estudo.

Com relação a metodologia Grupos de Oposição, o principal destaque volta-se para provocar no aluno a necessidade de argumentação e de reflexão para debater e discutir assuntos estudados durante a aula.

Finalmente, a aplicação da dinâmica de Grupo de Observação e de Verificação, destaca-se o potencial de desenvolver no aluno a capacidade de ouvir o outro, provocar a argumentação e discussão de conteúdos e elaboração de síntese.

Conclui-se indicando fortemente o uso de metodologias ativas no ensino presencial de logística e vislumbra-se uma oportunidade a se explorar relacionada a estudos 
misto.

\section{REFERÊNCIAS}

[1]. BARBOSA, E. F.; MOURA, D. G. de. Metodologias ativas de aprendizagem na educação profissional e tecnológica. Boletim Técnico Senac, 39 (2), p. 48-67, 2013.

[2]. BERBEL,N.N.: "Problematization" and Problem Based Learning: diferente word so diferente ways? Interface Comunicação,Saúde,Educação,v.2,n.2,1998.

[3]. DEWEY, J. Vida e Educação. São Paulo: Nacional. 1950a.

[4]. FREIRE, A.M.A. Paulo Freire: Uma História de vida. $1^{\underline{a}}$ Edição Editora Villa das Letras. Indaiatuba, SP. 2006.

[5]. FREIRE, P. Pedagogia da Autonomia. 36. ed, São Paulo: Paz e Terra, 2009.

[6]. MASETTO, Marcos Tarcísio. Competência pedagógica do professor universitário. São Paulo, Summs (2012).

[7]. NAGAI,W.A.\& IZEKI,C.A. Relato de experiência com metodologia ativa de aprendizagem em uma disciplina de programação básica com ingressantes dos cursos de Engenharia da Computação, Engenharia De

Controle e Automação e Engenharia Elétrica. Revista RETEC, v-4,p.1-10, 2013.

[8]. NEVES JÚNIOR, I. J. et al. METODOLOGIAS DE ENSINO: um estudo sobre o uso da aula expositiva e o método de caso aplicado à disciplina de Perícia Contábil. Rev. UCB Brasília. Brasília, 2014.

[9]. NOVAK, J. D.; GOWIN, D. B. Aprender a aprender. 2. ed. Lisboa: Plátano Edições Técnicas. 1999

[10]. ROGERS, C. Liberdade para Aprender. Belo Horizonte: Ed. Inter livros, 1973.

[11]. SANTOS, C. P. \& SOARES, S. R. Aprendizagem e relação professor-aluno na universidade: duas faces da mesma moeda. Est. Aval. Educ., São Paulo, v. 22, n. 49, p.353-370, maio/ago. 2011.

[12]. YIN, Robert K. Estudo de Caso: Planejamento e métodos. $3^{\underline{a}}$ ed. Porto Alegre Bookman, 2005.

[13]. Yin, R.K. Case study research, design and methods (applied social research methods). Thousand Oaks. California: Sage Publications (2009). 


\section{Gapítulo 16}

\section{TRANSPORTE URBANO DE CARGAS: UMA INDICACÃO OPERACIONAL PARA FAVORECER A MOBILIDADE URBANA ATRAVÉS DO VLT BAIXADA SANTISTA}

\section{Larissa Donato Leite}

\section{Lucas Mateus de Araujo}

\section{Denilson Luiz de Carvalho}

Resumo: O transporte urbano de cargas, apesar da sua enorme importância para o desenvolvimento econômico e social do país, é também um grande obstáculo para a organização e planejamento nas movimentações das cidades. O excesso de caminhões em vias urbanas é um dos motivos para tantos congestionamentos, acidentes e desperdício de tempo, fato que afeta diretamente as operações logísticas das empresas. Em razão da situação enfrentada nos centros urbanos, a pesquisa tem como objetivo explorar a operação de carga e descarga, utilizando o VLT (Veículo leve sobre trilhos) da Baixada Santista como base para o estudo a fim de favorecer a mobilidade urbana e beneficiar empresas em seu entorno. Para elaboração da pesquisa acadêmica foi adotada a metodologia exploratória, utilizando se de métodos qualitativos e apoiado por revisão bibliográfica.

Palavras-chave: Transporte de cargas. Veículo leve sobre trilhos. Mobilidade Urbana. 


\section{INTRODUÇÃO}

Uma tendência para o futuro é o deslocamento de pessoas pelo modal aéreo. Já existe, um exemplo é Dubai, "drones" taxiando pessoas de um ponto ao outro. Porém, nos países subdesenvolvidos e em desenvolvimento esse futuro tende a demorar algumas dezenas de anos e, são justamente esses que precisam arrumar soluções prementes para a mobilidade urbana e redução dos impactos negativos nos deslocamento de cargas e pessoas.

O transporte urbano, por sua enorme importância para o crescimento socioeconômico, e pela existência, cada vez maior, de grandes e médias cidades, vem sendo cada vez mais estudado e valorizado. Os impactos causados pelos transportes na qualidade de vida, principalmente da população urbana, faz com que áreas como a Engenharia Urbana e o Urbanismo, por exemplo, utilizem o estudo da mobilidade urbana como estruturador da construção das cidades (MOTTA 2013).

A Lei n. 12.587/12 - Lei de Mobilidade Urbana divide o transporte urbano em dois grupos: motorizado e não motorizado, onde os serviços de transporte são classificados quanto ao objeto de passageiros e cargas, a característica do serviço: coletivo e individual e quanto à sua natureza: público ou privado.

Mobilidade urbana é definida pelas formas e meios em que as cidades oferecem á população para a circulação entre diferentes áreas, e este é um dos maiores desafios tanto para o Brasil quanto para outros países. A Lei de Mobilidade Urbana exige a integração de políticas de planejamento e de mobilidade nas cidades brasileiras, com o objetivo de integrar os diferentes modos de transporte e a melhoria da acessibilidade e mobilidade das pessoas e cargas no território do Município

Para Sanches Junior (2008) as dificuldades das movimentações urbanas estão relacionadas ao crescimento expressivo do uso do automóvel, aliado a um sistema deficiente de transporte coletivo e de massa, e a impactos negativos provocados pela circulação de cargas em vias urbanas, tornando -se um grande desafio para a organização e planejamento das cidades.

Bergman e Rabi (2005, p. 10) afirmam que:

O sistema de mobilidade urbana pode ser considerado como um conjunto estruturado de métodos, redes e infraestruturas que garante o deslocamento de bens e pessoas nas cidades e que mantém fortes interações com as demais políticas urbanas.

O ambiente físico e social é diretamente afetado pelo grande fluxo de caminhões nas cidades. Consequentemente os níveis de poluição, tanto sonora como de gases tóxicos, elevam-se continuamente (LIMA JUNIOR, 2003). A grande frota de caminhões em vias urbanas reduz a capacidade de tráfego dos automóveis, devido ao tamanho e aceleração lenta, ocasionando diversos entraves durante o trajeto.

Para elaboração desta pesquisa / sugestão, as informações foram divididas em blocos. Inicialmente apresenta definições de mobilidade e transporte urbano de cargas, enfatizando suas deficiências. No segundo bloco exibe uma exploração para o transporte de cargas no VLT da Baixada Santista. Por fim busca mencionar a importância da implantação de melhorias para mobilidade urbana, focado ao transporte de cargas nas cidades. Farão parte da proposta conceitos importantes da logística: Milk Run, Cross Docking, Dropshipping, Gestão da armazenagem em trânsito FIFO (First in First out) e LIFO (Last in First out) de acordo com as características da transportação.

\section{REFERENCIAL TEÓRICO}

O capítulo que segue apresenta importantes conceitos relacionados ao transporte urbano de cargas, que servirão de base para sustentar o estudo. Primeiramente aborda conceitos relacionados a atividades logísticas em vias urbanas. Em seguida, conceitua operações logísticas pertinentes e ajustada aos sistemas de distribuição e armazenagem da sugestão aqui proposta.

\subsection{TRANSPORTE URBANO DE CARGAS}

Para Caixeta e Martins (2011), o enfoque, no que tange a problemática do transporte de cargas em vias urbanas, requer uma abordagem diferenciada perante os obstáculos que o setor de cargas enfrenta.

De acordo com a Lei no. 12.587/12, Art. 4º , o transporte urbano de cargas é definido pelo serviço de transporte de bens animais ou mercadorias.

Historicamente, o transporte de cargas sempre teve grande influência para o sistema 
econômico e desenvolvimento da sociedade, tornando se absolutamente essencial para a civilização moderna (CAIXETA; MARTINS 2011).

Segundo Dablanc (2007), conceitualmente, a distribuição urbana de cargas pode ser entendida como resultado de vários fluxos constantes de cargas, entrando, atravessando e saindo das áreas urbanas (apud VILELA; PESSINI, 2013).

\subsection{MILK RUN}

O Milk Run ou Milk pick-up é a programação de roteiros pré desterminados de coleta e dristribuição de vários produtos localizados próximos entre si e de seu destino. O sistema Milk Run tem o benefício de aumentar a frequência de entrega e aproveitar a capacidade de carga do veículo (BALLOU, 2006).

\subsection{CROSS-DOCKING}

A definição básica do cross-docking é o roteamento de mercadorias que são recebidas atráves de fornecedores e entregue aos clientes, sem a necessidade de estocagem, conforme apresentado na Figura 1.

De acordo com Barroso (2001), Crossdocking é um sistema em que produtos são recebidos em uma dependência, eventualmente junto com outras mercadorias de mesmo destino, são encaminhados na primeira oportunidade, sem uma armazenagem prolongada. A sincronização entre 0 recebimento e entrega de mercadorias é essencial para que a operação seja realizada com qualidade e eficiência.

Figura 1: Sistema Crossdocking

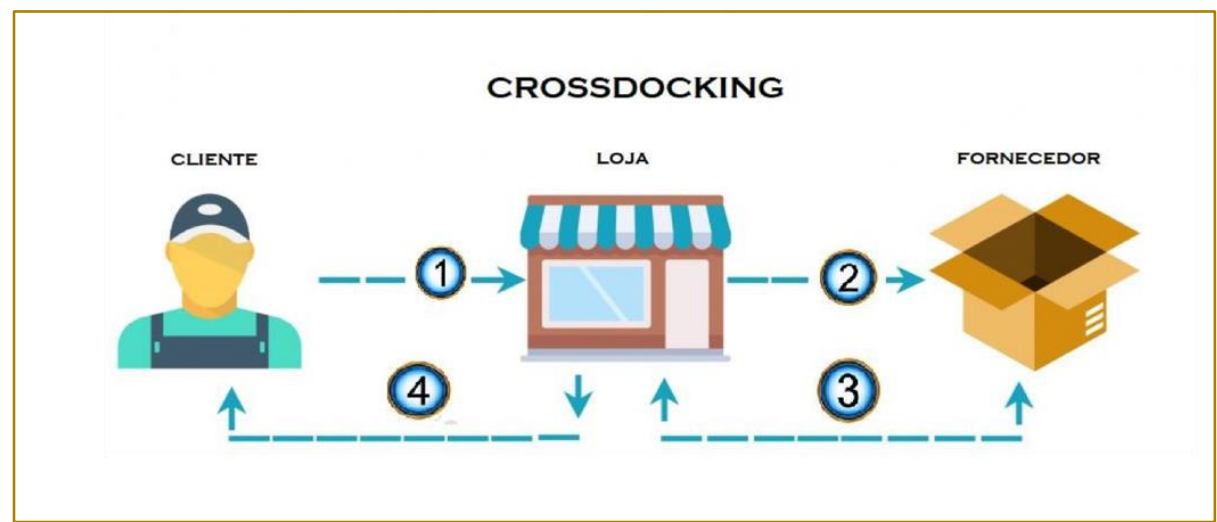

Fonte: Adaptada de Btstc-cluny (2018).

\subsection{DROPSHIPPING}

$\mathrm{Na}$ literatura, a operação logística dropshipping é definida como um sistema de distribuição onde dos produtos vendidos não passam por um intermediário, seguindo diretamente do fornecedor, ao cliente final.
O dropshipping é um sistema de atendimento onde uma loja não mantém seus produtos em estoque. Em vez disso, quando uma loja vende um produto, ela encaminha a ordem de compra para um terceiro e este o envia diretamente para o cliente final, ilustrado na Figura 2. Como resultado, o revendedor não tem acesso e não manipula 0 produto (HAYES, YOUDERIAN, p.1; 2013) 
Figura 2: Sistema DropShipping

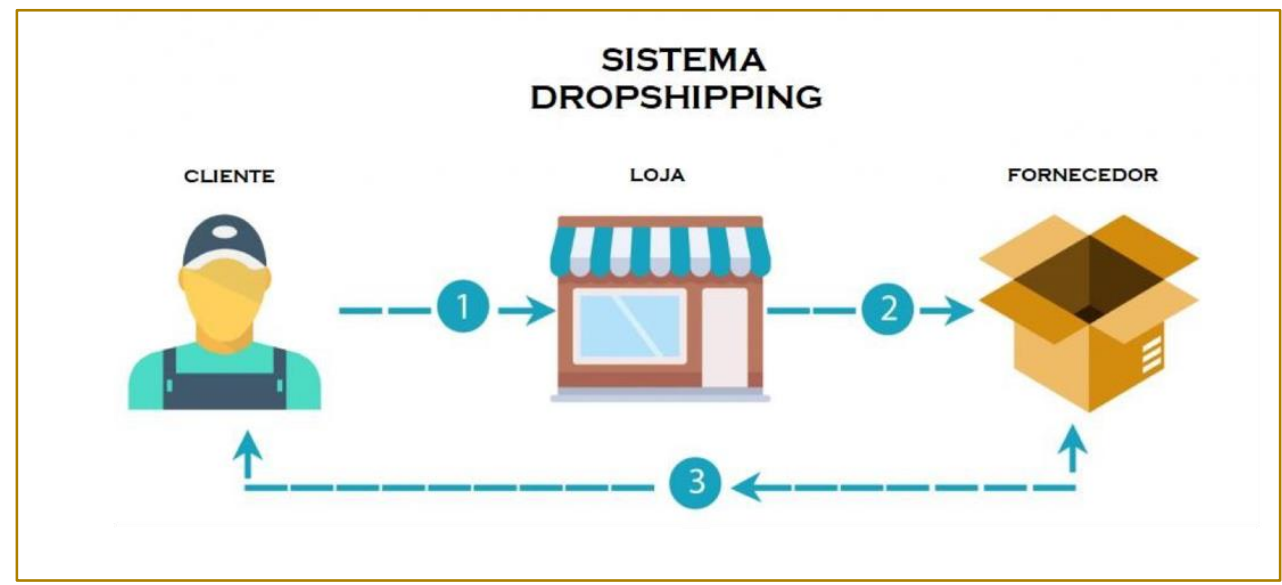

Fonte: Adaptada de Btstc-cluny (2018).

\subsection{SISTEMA DE ARMAZENAGEM - FIFO}

Ferreira (2007, p. 33) define FIFO como:

FIFO (first-in, first-out) apura que os primeiros artigos que entrarem no estoque, vão ser aqueles que vão sair em primeiro lugar, deste modo o custo da matéria prima deve ser considerado pelo valor de compra desses primeiros artigos.

O método FIFO (First in, First out) ou PEPS é a avaliação feita pela ordem cronológica das entradas de produtos em determinado estoque. Sai o material que primeiro adentrou ao estoque, sendo substituído pela mesma ordem em que foi recebido (DIAS, 2009).

\subsection{SISTEMA DE ARMAZENAGEM - LIFO}

No método LIFO (Last-in, First out), as mercadorias que entram por último no estoque, são as primeiras que sairão no momento da venda.

De acordo com Basso (2011), o método LIFO ou UEPS, último que entra é o primeiro que sai, refere-se ao mecanismo no qual também se faz necessário o controle de forma sucessiva como no PEPS, mas neste caso o custo será avaliado, considerando se os preços de custo e ordenando os produtos dos últimos para os primeiros, isto é, o ultimo que entra é o primeiro que sai.

Para o projeto apresentado, devido às mais sortidas particularidades, possivelmente 0 sistema de armazenagem em trânsito será uma mescla de ora FIFO ora LIFO.

\section{METODOLOGIA}

A metodologia adotada é exploratória, com revisão bibliográfica e adoção de métodos qualitativos. Para realização do estudo, foi utilizado como cenário de pesquisa o VLT da Baixada Santista.

As estações "Milk Run" foram definidas conforme concentração de estabelecimentos comerciais de todo o tipo e visando uma operacionalização com destinos bem abrangentes.

\section{DESENVOLVIMENTO DA TEMÁTICA}

A maior parte dos veículos utilizados para transporte de cargas urbanas são caminhões, de acordo com Caixeta e Martins (2011). Em virtude do aumento da frota destes veículos em vias urbanas, surgem inúmeras consequências, tais como: acidentes, congestionamentos, poluição ambiental, sonora e principalmente o desperdício de tempo, fato que atinge diretamente a operação logística das empresas.

Diante deste cenário, está proposta a ideia de implementação do transporte de cargas utilizando um último vagão do VLT (que será adicionado à composição com layout moldado para o transporte de cargas, evitando diminuir o espaço dos usuários) que poderá ser acrescentado na composição. As estações de carga e descarga deverão ser moldadas / idealizadas para esses fins.

Três importantes fatores são definidos: estações de "Milk Run", armazenagem em trânsito e o método adotado para carga e descarga (esse último talvez seja o mais 
crítico desta sugestão, pois não poderá atrapalhar / aumentar o tempo de parada). Para o presente estudo, utilizou-se como exemplo o VLT da Baixada Santista.

\subsection{ESTAÇÕES MILK RUN}

Para realização desta operação, foi de extrema importância a escolha correta das estações Milk Run (carga e descarga).Os pontos foram estrategicamente escolhidos levando em consideração a direta influência aos estabelecimentos em seu entorno. llustrado na Figura 3.

Figura 3: Estações Milk Run

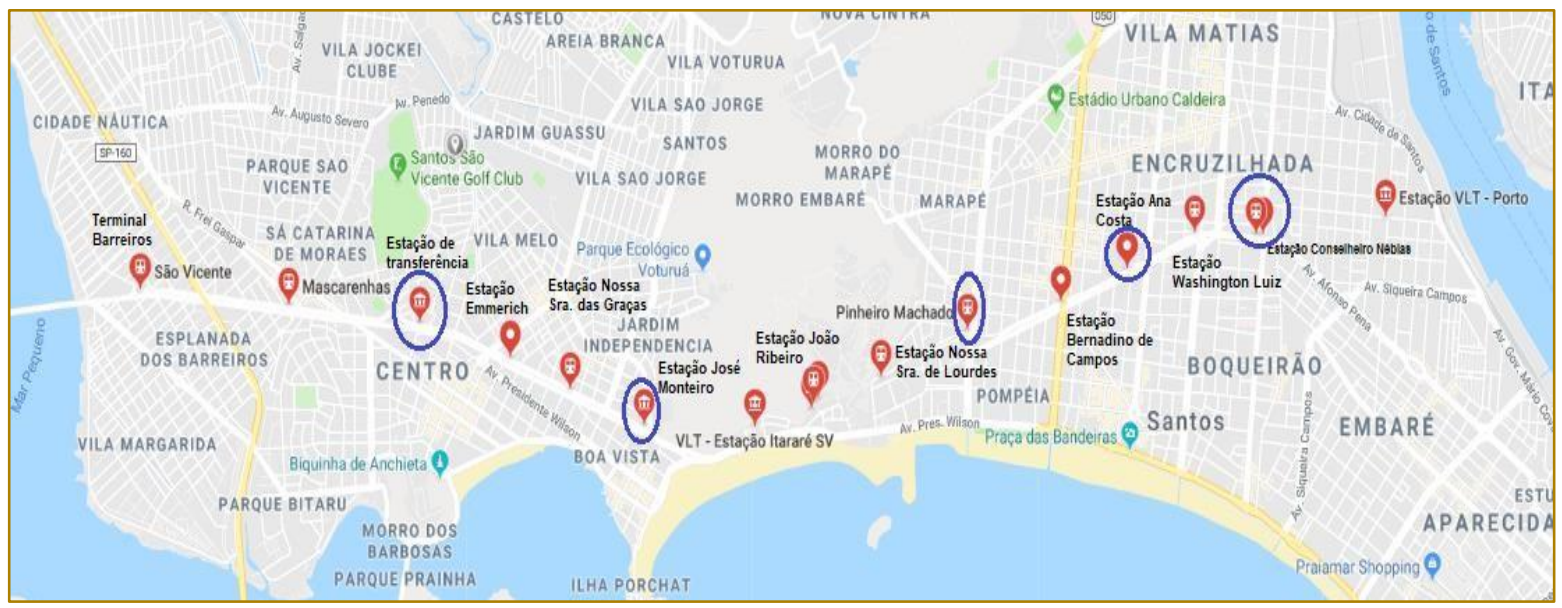

Fonte: Google Maps (2018)

Conforme identificadas na figura 3 , as estações foram selecionadas devido à abrangência de áreas de comércio, dentre elas estão: Estação de Transferência S.V; Estação José Monteiro; Estação Pinheiro Machado; Estação Ana Costa, por fim a Estação Conselheiro Nébias.

Ao redor das estações selecionadas, foi possível observar a presença de uma considerável concentração de estabelecimentos atuantes em diversos segmentos. Os ramos em que serão possíveis atingir são dos mais variados, dentre eles: Supermercados, bares e restaurantes, hospitais, lojas de departamento, postos de gasolina e farmácias.

\subsection{CARGA E DESCARGA}

A operação de carga e descarga deverá estar sincronizada paralelamente ao tempo préestabelecido de embarque e desembarque de passageiros, sendo um lado apenas para entrada e o outro para a saída de cargas, a fim de não interferir e atrasar o percurso. Essa sincronização é que indicará / ratificará a viabilidade desta proposta.

\subsection{OPERACIONALIZACCÃO INTERNA: ARMAZENAGEM EM TRÂNSITO}

É certamente impossível definir apenas um método para carga e descarga, pois produtos serão carregados nas estações definidas "Milk Run" para os mais diversos destinos. Um produto poderá percorrer $100 \%$ do trajeto, enquanto outros poderão ser descarregados uma estação após a carga. Para ajustar a operacionalização aos conceitos logísticos pode-se ratificar que será utilizada uma mescla de dois métodos já fundamentados FIFO e LIFO. A organização interna ficará a cargo de pessoa(s) treinadas para a operação. As principais atribuições dessa(s) pessoa(s) será organizar e controlar o fluxo de entrada e saída dos materiais, e principalmente otimizar o espaço útil do vagão.

\subsection{DISTRIBUIÇÃO}

Para a operação de distribuição, poderá ser adotado tanto o sistema cross- docking (os produtos saem do vagão para outro veículo coletor, unitizando a carga para um único 
destino) como o dropshopping (o próprio destinatário retira a mercadoria).

\subsection{RESULTADOS E DISCUSSÃO}

Em decorrência do que foi apresentado, pode-se destacar como ponto positivo deste projeto / sugestão, a melhoria na circulação de veículos dos centros urbanos, em função da redução de caminhões de cargas nas cidades (principalmente ao referenciar o VLT da Baixada Santista, pois seu trajeto está definido fora do centro da cidade). Outros aspectos importantes que devem ser considerados são: a diminuição da emissão de poluentes, devido ao VLT utilizar apenas energia elétrica, o tempo e custo desta operação logística poderão ser

reduzidos e o principal, há a possibilidade de favorecer a mobilidade urbana (os PGTs ${ }^{1}$ que deverão ser plenamente planejados estarão no entorno das estações Milk Run). Por outro lado, pode-se ressaltar como pontos negativos a limitação de capacidade de carga, tipos de produtos (somente cargas pequenas e de pouco peso) e o raio de alcance para os estabelecimentos em torno das estações Milk Run.

\section{REFERÊNCIAS}

[1]. BALLOU, R.H. Gerenciamento da cadeia de suprimentos/logística empresarial. 5aㅡ ed. Porto Alegre/SC: Bookman, 2006.

[2]. BARROSO, F. A Operação de Cross
Docking. <http://www.ilos.com.br/web/a-operacao-de-crossdocking> Acesso em 31 mar.2018 BASSO, I. P. Contabilidade Geral Básica. 4ª .ed. Brasil :Unijuí, 2011

[3]. MINISTÉRIO DAS CIDADES. Mobilidade e política urbana: subsídios para uma gestão integrada. Disponível em: <http://www.mobilize.org.br/midias/pesquisas/mobi lidade-e-politica-urbana.pdf> Acesso em 24 mar. 2018.

[4]. BTSTC-CLUNY. Start a Drop Shipping Business from Home. Disponível em: <http://btstccluny.org/start-a-drop-shipping-business-fromhome> Acesso em: 21 mar. 2018.

[5]. CAIXETA FILHO V. J.; MARTINS S. R, Gestão Logística do Transporte de Cargas. São Paulo: Atlas S.A, 2011.

[6]. CNT. Transporte Rodoviário de Passageiros em Regime de Fretamento 2017. Disponível em <http://www.cms.cnt.org.br> Acesso em 15 mar. 2018.

\section{CONSIDERAÇÕES FINAIS}

O objetivo principal do presente estudo foi sugerir a implementação do transporte de cargas em veículo leve sobre trilho, utilizando como estudo de caso o VLT da Baixada Santista. A pesquisa demonstra a importância e viabilidade de se desenvolver planos logísticos para o transporte urbano de cargas, direcionado, principalmente às empresas localizadas em torno das estações do VLT. Foi possível notar que através de implantações de sistemas de distribuição e armazenagem, a operação em questão pode se tornar uma ferramenta logística de extrema importância no que tange mobilidade urbana. Diminuição da frota de veículos de carga, redução de poluentes e principalmente as possíveis reduções do tempo e custo estão entre os benefícios desse sistema.

Por fim, esta pesquisa permitiu explorar melhorias para o transporte de carga em centros urbanos, o que poderá contribuir para estudos futuros que buscam 0 aperfeiçoamento dessas operações em vias urbanas, favorecendo as condições de mobilidade urbana em uma visão geral.

[7]. DIAS, M.A.P. Conceitos Administração de materiais: princípios e gestão. 6 ed. São Paulo: Atlas, 2009

[8]. DUTRA, N.G.S. Novos Conceitos e Tecnologias na Distribuição Urbana de Mercadorias. Disponível em: <http://www.clubbrasil.org/downloads/Dutra,\%20N ovaes,\%20Moreira\%20(2006).pdf> Acesso em 5 mar. 2018.

[9]. JUNIOR, O.F.L. A carga na cidade: Hoje e amanhã. Disponível em: <http://www.emdec.com.br/ciclo2012/downloads/1 0_08_AGO_ArtigoFuturoTransport eCargas.pdf> Acesso em : 02 mar. 2018.

[10]. JUNIOR, P.F.S. Logística de Carga Urbana: uma análise da realidade brasileira. Disponível<http://www.clubbrasil.org/downloads/Sa nches\%20Junior\%20\%282008\%2 9.pdf> Acesso em: 19 mar. 2018

[11]. MEIOS DE TRANSPORTE. Transporte Coletivo. Disponível em<http://meios-detransporte.info/transporte-terrestre/transportecoletivo.html> Acesso em 28 mar. 2018.

[12]. MOTTA, M. W. V. O Veículo Leve sobre Trilhos: Considerações sobre seus atributos como justificativa para implantação. Dissertação (Mestrado em Engenharia Urbana. Disponível em: 
<http://www.dissertacoes.poli.ufrj.br/dissertacoes/d issertpoli981.pdf> Acesso em 20 mar. 2018.

[13]. PLANALTO. Lei № 12.587, De 3 De Janeiro De 2012. Disponível em: <http://www.planalto.gov.br/ccivil03/ato20112014/2 012/lei/l12587.html> Acesso em: 30. Mar. 2018

[14]. TECMUNDO. Dubai testa primeiro drone para serviço de "táxi aéreo sem piloto". Disponível em:

$<$ https://www.tecmundo.com.br/produto/122421-

dubai-testa- primeiro-drone-servico-taxi-aereopiloto.htm> Acesso em: 05. Abril. 2018

[15]. VILELA, O.V. et al .Transporte Urbano De Cargas: reflexões à luz da geografia dos transportes. Disponível

em: $<$ http://www.observatorium.ig.ufu.br/pdfs/5edicao/n 14/06. > Acesso em 2 mar. 2018 


\section{Capítulo 17}

\section{LOGÍSTICA NO E-COMMERCE: \\ CONSUMIDOR}

\section{Cibelle William Costa}

Suellen Yañes da Silva

\section{Edna Veloso de Medeiros}

Resumo: O objetivo do artigo é analisar a relação da logística no e-commerce e a visão do consumidor. A partir de uma pesquisa exploratória e bibliográfica, um modelo de hipótese foi elaborado, para teste de uma pesquisa descritiva. Foi feito o levantamento de campo através de um questionário estruturado que foi disponibilizado na internet, e que resultou em uma amostra de cinquenta e seis respondentes. Nos resultados, foram verificados que é possível admitir que muitas pessoas ainda compram através de sites online, devido a sua facilidade de pesquisa e comparação de preços do produto desejado, ou seja, mesmo com todas as dificuldades existentes, o e-commerce ainda é um meio de compras muito utilizado, que fornece praticidade e comodidade ao consumidor, o que é um fator importante atualmente.

Palavras-Chave: Logística. E-commerce. Consumidor. 


\section{INTRODUÇÃO}

Com o avanço da Internet e de todas as tecnologias disponíveis no mercado, surgiu uma nova demanda que se consolidou e vem crescendo constantemente: o mercado do comércio eletrônico. Com a ampliação desse mercado e suas infinitas possibilidades, houve a necessidade de repensar as estruturas logísticas desse comércio para atender seus clientes com qualidade. Além disso, verificou-se a necessidade de calcular os custos quanto ao frete e considerar o tempo de entrega dos produtos.

Assim, utiliza-se a logística como um meio para propor as devidas soluções para esses e outros problemas que ainda assolam 0 mercado do e-commerce no Brasil.

A logística, atualmente é considerada como o principal fator de sucesso para um ecommerce Borges (2003), uma vez que ela tem influência direta na satisfação do consumidor. Desta forma, é preciso investir em processos logísticos adequados e eficazes, pois afetam diretamente no desempenho dos níveis de serviços oferecidos aos clientes e, sabe-se que, o nível de contentamento do cliente com o serviço prestado está diretamente relacionado com a fidelização deste com a marca ou empresa em questão. Portanto, a logística tornou-se primordial para as empresas, principalmente as que vivem no modo "on-line".

Este estudo tem o objetivo de analisar a relação da logística no e-commerce e a visão do consumidor.

Os dados para este estudo foram coletados por meio de um levantamento bibliográfico acerca do tema abordado, como também, por meio de uma pesquisa de campo com questões disponibilizadas na internet, dando um caráter descritivo e quali-quantitativo a esta análise.

\section{REVISÃO DA LITERATURA}

O comércio eletrônico no Brasil originou-se no final da década de 90, como consequência do avanço da internet levando as organizações vislumbrarem uma enorme possibilidade de transações neste mercado em virtude de um público cada vez maior. (SOUZA, 2013)

Sabe-se que este tipo de mercado tem inúmeras vantagens, dentre elas a redução do tempo de compra, pesquisa em tempo real, busca pelo melhor preço, praticidade e a busca por informações do produto desejado ou da empresa em questão. Já sob o ponto de vista das empresas, esse meio possibilita redução de custos e a oportunidade de conseguir novos clientes com maior rapidez e facilidade. (FAM, 2008)

De forma clara e ampla, o comércio eletrônico pode ser definido como:

O comércio eletrônico é a realização de toda a cadeia de valor dos processos de negócio num ambiente eletrônico, por meio da aplicação intensa das tecnologias de comunicação e de informação, atendendo aos objetivos de negócio. Os processos podem ser realizados de forma completa ou parcial, incluindo as transações negócio-a-negócio, negócio-a- consumidor e intra-organizacional, numa infra-estrutura predominantemente pública de fácil e livre acesso e baixo custo. (ALBERTIN, 2000, p. 108)

Para Kotler (2000), o e-commerce é realizado tanto por empresas físicas ou exclusivamente virtuais que efetuam ou facilitam a venda de produtos e serviços on- line.

O comércio eletrônico, hoje, não é mais uma tendência e sim uma realidade e no Brasil pode-se dizer que a sua maior vantagem seja o encurtamento de barreiras demográficas. Com a utilização do e-commerce pode-se negociar com o mundo todo em instantes. Segundo o Ebit, maior site sobre as informações do mercado de comércio eletrônico no Brasil, o ano de 2016 encerrou com $R \$ 44,4$ bilhões contra $R \$ 41,3$ bilhões em 2015 e a tendência é que esse valor aumente em $12 \%$ no faturamento do ecommerce brasileiro. (ISTO É, 2017)

\subsection{VANTAGENS NO COMÉRCIO ELETRÔNICO}

O mercado de comércio eletrônico através da Internet viabilizou inúmeras operações e benefícios em relação ao comércio tradicional, aquele realizado pessoalmente. 0 e-commerce traz algumas vantagens como a facilidade e agilidade na transferência de informações entre clientes e fornecedores, aumentando $\mathrm{o}$ fluxo de transações e reduzindo o tempo entre elas. (SILVA, 2003)

Silva (2003), ainda acrescenta como vantagem a diminuição do tempo do ciclo de pedidos e eliminação de erros. Já, Borges 
(2003), cita o melhor atendimento e suporte ao cliente, assim como, a comodidade e o conforto em receber seus produtos em casa. Além da pesquisa e comparação dos melhores preços em tempo real, tem como um fator relevante a redução de custos quanto às despesas de uma loja física. (DINIZ, 1999)

\subsection{LOGÍSTICA}

Para Ballou (1993), a logística é o estudo de como a administração pode melhorar o nível de rentabilidade nos serviços de distribuição aos clientes e aos consumidores, tendo em vista o planejamento, a organização e controle para as atividades como a movimentação e armazenagem, que facilitam o fluxo de produtos. Novaes (1989), diz que a logística tem como objetivo solucionar problemas,

tais como na área de setor produtivo (transporte, suprimentos, entre outros), na distribuição de produtos acabados e semiacabados (armazenagem, distribuição, processamento de pedidos e etc.), localização dos armazéns entre outros. Deste modo, procurando compreender os seus tipos de restrições, tanto de ordem espacial (deslocamento de produtos) e de ordem temporal (prazos de entrega, confiabilidade operacional, dentre outros).

Logística pode ser entendida também como:

A parte do processo da cadeia de suprimentos que planeja, implementa e controla de forma eficiente e eficaz, a expedição, o fluxo reverso e a armazenagem de bens e serviços, assim como do fluxo de informações relacionadas, entre o ponto de origem e o ponto de consumo, com o propósito de atender às necessidades dos clientes. (FARIA; COSTA, 2009, p. 16)

Como esta não é de uma definição exata, é possível ser identificado diversas discussões a respeito de seu conceito. A conceituação é realizada por muitos autores e teoricamente estuda-se como otimizar os recursos de produção. A logística é primordial para uma organização que queira obter sucesso, porque ela redireciona a empresa para um melhor desempenho, tendo potencial para alcançar seus objetivos e atingir metas.

\subsection{LOGÍSTICA EMPRESARIAL}

A logística empresarial pode ser entendida como a logística que cuida de todas as atividades de movimentação, armazenagem, distribuição, com objetivo de traçar serviços adequados para os clientes e consumidores. Ela estuda como uma boa administração pode melhorar o nível de desempenho da organização, para assim trazer os resultados positivos em seu serviço.

Para Pozo (2010), apud Pozo (2015, p.1):

A logística empresarial trata de todas as atividades de movimentação e armazenagem que facilitam o fluxo de produtos desde o ponto de aquisição da matéria-prima até o ponto de consumo final, assim como dos fluxos de informação que colocam os produtos em movimento, com o propósito de providenciar níveis de serviço adequados aos clientes a um custo razoável.

Quando a logística empresarial é bem compreendida, ela ajuda na melhoria da estrutura organizacional e também com qualidade do fluxo de bens dentro do processo produtivo. Quando a organização está interessada em melhorar o grau de sua eficiência, deve estar ligada as mudanças decorrentes no ambiente, devido aos grandes avanços da tecnologia e também da economia. Ou seja, ela nasceu da importância de redução de custos e também para tornar a empresa mais eficiente e competitiva.

\subsection{LOGÍSTICA E E-COMMERCE}

A logística é um dos principais pontos para o sucesso do comércio virtual, e ela possui a mesma definição para qualquer tipo de comércio, ou seja, ela é responsável por todo o planejamento, controle do armazenamento e distribuição dos produtos, do seu ponto de origem até o destino final. (SEBRAE, 2016)

Em um ambiente virtual, ele possui características únicas, como por exemplo o seu funcionamento 24 horas por dia, a sua disponibilização de informações, a divulgação para poder ter visibilidade etc. É muito importante a sua troca de informações com o cliente, por exemplo informações sobre o produto, o seu preço, o prazo de entrega e como ele será feito, avaliações de clientes e um site de fácil utilização. (SEBRAE, 2016)

O Sebrae (2017) mostra as principais etapas de um comércio eletrônico:

a) Preparar o pedido: o comprador precisa escolher o produto, mas antes disso 
é necessário que no site tenha disponível as informações do produto, como por exemplo: o valor, o tamanho, a cor etc., e assim ele irá tomar a decisão da compra. Diante disso, deve aguardar a autorização da transação financeira e transmitir o seu pedido para 0 site.

b) Processamento do pedido: Quando o pedido é feito pelo cliente, o pagamento passa por um processo de análise para ser combatida qualquer fraude. Esse processo é feito por empresas especializadas, como administradora de cartões de crédito e empresas antifraudes. Após a conclusão desta análise, o pedido é validado com o risco de fraude eliminado, passando para o financeiro e assim concluindo o processo de confirmação de pedido.

c) Confirmação do pedido: após ser aprovado a transação financeira, deve ser feito a separação do pedido, a embalagem, emissão do documento fiscal e a

d) entrega ao transportador. E a partir desse momento, começa a ser contado o prazo de entrega.

e) Entrega: o momento em que a mercadoria está sendo enviada ao destinatário. É possível oferecer rastreamento da encomenda para o cliente, após o pedido ser entregue a transportadora.

\subsection{PROBLEMAS NO E-COMMERCE}

É preciso ter consciência de que é extremamente importante investir nas operações logísticas para que se tenha um comércio eletrônico de longa vida no mercado.

De acordo com Cristofolini (2017), os problemas mais comuns encontrados são:

a) Logística Reversa: esse pode ser considerado um dos maiores e principais problemas desse tipo de comércio. Quando o produto não atende as expectativas do cliente, não seja do tamanho adequado ou esteja com algum defeito é preciso que o consumidor devolva o produto indo até uma agência dos Correios ou espere com que a transportadora faça a coleta à domicílio.

b) Ausência no recebimento: outro fator que deve ser considerado pelas empresas que realizam as entregas do e-commerce. Devido ao cotidiano corrido das pessoas, muitas entregas retornam aos centros de distribuição por não encontrarem os consumidores.

c) Custo elevado do frete: fator que ainda tem muita relevância na hora da aquisição através da internet, assim como, para as transportadoras.

\section{MÉTODO}

O método utilizado neste trabalho foi o método de pesquisa exploratória e bibliográfica, definindo-se os principais conceitos envolvidos através de pesquisas realizadas em sites e revistas especializadas, artigos de profissionais da área como também livros relacionados aos assuntos discutidos. Essa pesquisa também teve um caráter descritivo, onde foi elaborado um questionário disponibilizado na internet através da ferramenta Google Docs para a realização da coleta de dados que fornecessem a visão do consumidor usuário de e-commerce.

O questionário foi composto por 10 questões que definiam os perfis dos usuários desses serviços, incluindo aspectos socioeconômicos e demográficos. Tal questionário foi compartilhado através de redes sociais como Whatsapp e Facebook por um período de 3 dias.

Com este questionário, obteve-se inicialmente cerca de 70 respostas, com as quais foi realizada uma análise qualitativa considerando a opinião dos consumidores com relação aos serviços oferecidos pelo comércio eletrônico, focando nos problemas encontrados durante os serviços.

\section{RESULTADOS E DISCUSSÃO}

Considerando as respostas obtidas através do questionário, percebe-se inicialmente, que - público mais assíduo dos serviços oferecidos pelo comércio eletrônico encontrase na faixa de 16 a 30 anos, correspondendo à mais de $74 \%$ dos entrevistados. É possível notar que mais de $54 \%$ dos entrevistados são mulheres, o que confirma uma tendência quanto ao poder de compra feminino. Tais observações puderam ser feitas através dos gráficos criados conforme as figuras 1 e 2 a seguir. 
Fig 1 - Faixa etária de usuários de e-commerce

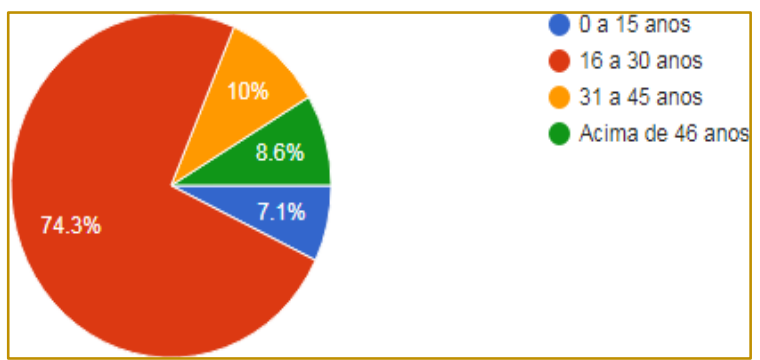

Fonte: Elaborado pelas autoras (2017).

Fig 2 - Sexo dos usuários de e-commerce

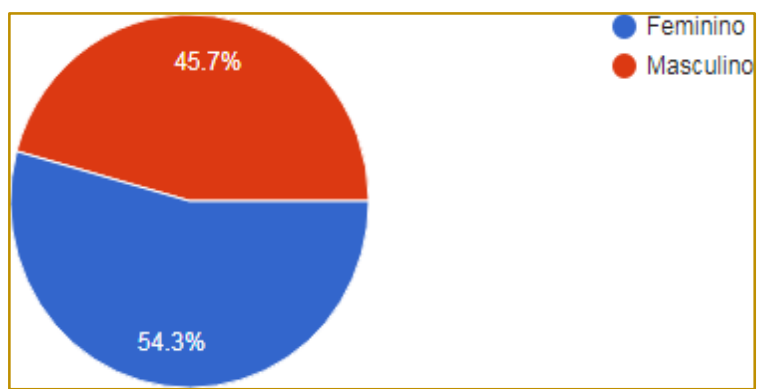

Fonte: Elaborado pelas autoras (2017).

Com relação ao acesso à internet, cerca de 98\% dos entrevistados tem acesso à rede, como também pode-se observar que esse acesso é feito prioritariamente através de celulares/smartphones, talvez por ser um equipamento portátil e de fácil alcance. Tendo acesso à internet, foi possível constatar que quase $90 \%$ dos entrevistados fazem ou já fizeram compras online, o que confirma uma tendência desse mercado que já se estabeleceu no Brasil.

O ponto principal desta pesquisa foi baseado nos problemas encontrados pelos usuários durante o processo de compra online, sendo assim, foi possível comprovar que um dos principais problemas citados pelos entrevistados foi realmente em relação ao alto valor do frete oferecido pelas empresas online, podendo até ultrapassar o valor da mercadoria. Outro problema foi em relação ao prazo de entrega dos produtos que muitas vezes não é respeitado, o que só comprova o que já foi levantado através da pesquisa bibliográfica. A figura 3 mostra os resultados encontrados relacionando os problemas citados.

Fig 3 - Problemas dos usuários de e-commerce

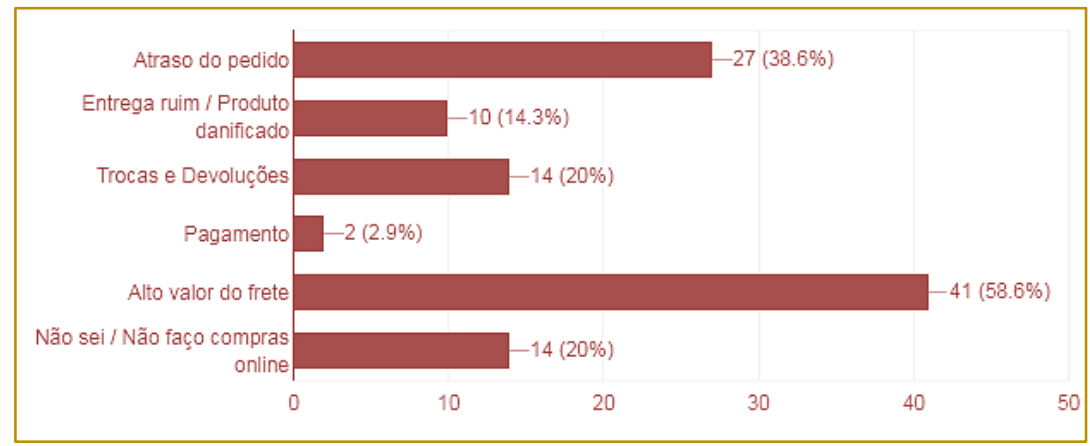

Fonte: Elaborado pelas autoras (2017). 
Mesmo com todos os problemas encontrados durante a compra online, de acordo com a pesquisa realizada é possível admitir que muitas pessoas ainda compram por esse meio devido a facilidade durante a pesquisa e comparação de preços do produto desejado, ou seja, mesmo com as dificuldades existentes, ainda é um meio de compras que fornece praticidade, o que é um fator importante no cotidiano corrido do dia-a-dia.

\section{CONSIDERAÇÕES FINAIS}

A pesquisa aqui apresentada teve como foco o e-commerce e o seu objetivo é poder entender melhor a visão do consumidor e a importância da logística no e- commerce.

A logística é o elemento essencial para as empresas que desejam obter sucesso, aumentando o desempenho de seu serviço, pois ela é responsável por planejar, armazenar e distribuir os produtos, desde seu ponto de origem até o cliente final. É de possível compreensão, que quando é prestado um bom serviço, o consumidor

\section{REFERÊNCIAS}

[1] Albertin, A. L. Comércio eletrônico: modelo, aspectos e contribuições de sua aplicação. São Paulo: ATLAS, 2000.

[2] Ballou, R. H. Logística Empresarial: transportes, administração de materiais e distribuição física. Ed. Atlas, 1993.

[3] Borges, L. B. A logística no comércio eletrônico. Centro Universitário de Brasília. Brasília, 2003.

[4] Cristofolini, J. Quais são os quatro grandes problemas do e-commerce. 2017. Disponível em: < https://www.ecommercebrasil.com.br/artigos/4-

grandes- problemas-do-e-commerce-e-comoresolve-los/> Acesso em: 25 de out. 2017.

[5] Diniz, E. H. Comércio eletrônico: fazendo negócios por meio da internet. Revista de Administração Contemporânea, Curitiba, v.3, n. 1, p. 71-86. 1999. Disponível em: < http://www.scielo.br/scielo.php?script=sci_arttext\& pid $=\$ 1415-\quad 65551999000100005 \&$ Ing $=$ pt\&tlng=pt >. Acesso em: 25 out. 2017.

[6] FAM. O crescimento do e-commerce no Brasil: estudo de caso do "SUBMARINO". 2008. Disponível em:<http://vemprafam.com.br/wpcontent/uploads/2017/03/OS_0003_16_fam_revista_ tende a elevar a sua satisfação, resultando a confiança na empresa.

Com base no referencial teórico e no levantamento de dados, foi possível perceber que muitas pessoas compram por sites online, isso é uma vantagem para as empresas de ecommerce, pois o custo para ter uma empresa online é bem menor em relação a uma empresa com loja física.

Sabemos que mesmo sendo muito utilizado, as compras online têm as suas vantagens e desvantagens, temos como exemplo a vantagem que seria a redução do tempo para se fazer uma compra, a busca pelos melhores preços, a praticidade e a facilidade. Já como desvantagens, vimos que alto custo do frete e a logística reversa, são os que mais chamam atenção entre as experiências dos consumidores. Portanto, ficou evidenciado que as análises estatísticas feitas comprovam o assunto que foi levantado com as pesquisas bibliográficas e foram suficientes para

conseguir ter uma boa compreensão do respectivo assunto.

interAtiva_n--3.pdf\#page=69>.Acesso em:26 de out. 2017.

[7] Faria, A. C. de; Costa, M. F. G. de. Gestão de Custos Logísticos. Ed. Atlas, 2009.

[8] ISTO É. Ebit projeta crescimento de 12\% nas vendas do e-commerce em 2017. Disponível em: <https://istoe.com.br/ebit-projeta-crescimentode-12-nas-vendas-do-e- commerce-em-2017/>. Acesso em:26 de out. 2017.

[9] Kotler, P. Administração de Marketing. 10ª Edição, $7^{a}$ reimpressão - Tradução Bazán Tecnologia e Lingüística; revisão técnica Arão Sapiro. São Paulo: Prentice Hall, 2000.

[10] Novaes, A. G. Sistemas Logísticos: Transporte, Armazenagem e Distribuição de Produtos. Ed. Edgard Blucher, 1989.

[11] Pozo, H. Logística e Gerenciamento da Cadeia de Suprimentos. Ed. Atlas, 2015.

[12] Sebrae Nacional. Logística é um dos pontos-chave no comércio eletrônico. 2016. Disponível em: < http://www.sebrae.com.br/sites/PortalSebrae/artigo s/logistica-e- um-dos-pontos-chave-no-comercioeletronico,b30e438af1c92410VgnVCM100000b272 010aRCRD>. Acesso em: 31 de out. 2017.

[13] Sebrae Nacional. Logística no ecommerce: entregar o produto no prazo é fundamental. 2017. Disponível 
em:<https://www.sebrae.com.br/sites/Port alSebrae/sebraeaz/logistica-no-e-commerceentregar-o-produto-no-prazo-efundamental,685f55a4873c4410VgnVCM1000003b 74010aRCRD>. Acesso em: 31 de out. 2017.

[14] Sebrae Nacional. Vantagens e desvantagens do comércio eletrônico. 2014. Disponível em:

$<$ https://www.sebrae.com.br/sites/PortalSe brae/artigos/vantagens-edesvantagens-docomercio-

eletronico,3e8a438af1c92410VgnVCM100000b272 010aRCRD>. Acesso em: 31 de out. 2017.

[15] Silva, L. G. P. O Comércio Eletrônico e a Logística Integrada, Guia Log. São Paulo: Instituto IMAM, 1999. Guia de Logística. Março, 2003.
[16] Souza, T. S. E-commerce B2C: panorama e evolução na realidade brasileira. 2013.

[17] 11 f. Monografia (Graduação) Universidade Católica de Brasília, Brasília, 2013. Disponível em:

https://repositorio.ucb.br/jspui/handle/10869/1853 >. Acesso em: 26 out. 2017.

[18] Valle, A. Logística no e-commerce. Disponível em:<https://www.guiadeecommerce.com. br/logistica-no-ecommerce>. Acesso em: 05 de nov. 2017.

[19] "O conteúdo expresso no trabalho é de inteira responsabilidade do(s) autor(es)." 


\section{Gapítulo 18}

\section{OS GANHOS DE PRODUTIVIDADE COM O USO DO METODO ABC NO GERENCIAMENTO DA ARMAZENAGEM E ESTOQUE: ESTUDO DE CASO NA EMPRESA JFL FIOS E CABOS}

\section{Fernando Júlio Martines}

Júnior Lemes

Marcos Antônio Luciano

Resumo: O objetivo deste trabalho é qualificar a real importância do gerenciamento de estoque, por uma ferramenta conhecida como curva $A B C$ em um centro de distribuição de uma instituição privada, do setor de produção de fios e cabos, na cidade de Sorocaba (SP). O gestor responsável pelo estoque usou a técnica de armazenamento Curva ABC. Colocando o material classe A no inicio do seu estoque para diminuir as movimentações para atender melhor e mais rápido seus pedidos, assim minimizando seus custos tanto com perdas e Mao de obra. A ferramenta denominada curva ABC é fundamental para conhecer a importância de cada item dentro da área de estoque a fim de mostrar quais itens possuem maior ou menor demanda. A metodologia utilizada foi por meio de visitas técnicas e entrevistas com responsáveis da área de armazenagem destes produtos, com análises qualitativas e quantitativas, por meio de dados coletados, referentes à movimentação dos materiais no período fiscal. Foi possível comprovar as teorias de diversos autores sobre a classificação da curva $A B C$, mostrando a importância fundamental da utilização para um gerenciamento de estoque possível de ser analisado. As considerações finais mostraram que na área de armazenagem, vários itens identificados como pertencente à Classe $\mathrm{C}$, com custos financeiros muito altos, a necessidade de uma revisão minuciosa para identificar se há necessidade de todos os materiais desta classe permanecer em local de armazenagem.

Palavras-Chave: Armazenagem e Estoque, Curva ABC, Supply Chain Management 


\section{INTRODUÇÃO}

O cenário econômico de alguns países sejam eles em níveis locais, regionais ou até mesmo em níveis globais, estão em constantes adaptações de recursos financeiros. O Brasil está passando por uma realidade de conflitos políticos e sócio econômico, muitas empresas estão realizando novos planejamentos e uma reestruturação em seus planos empresariais.

Para melhoria nas estruturas industriais é necessário à implantação de sistemas e ferramentas logísticas, estes sistemas e ferramentas são fatores primordiais para o desenvolvimento do processo de melhoria dentro das indústrias.

Toda a área das empresas tem a necessidade de compreender o melhor fluxo de materiais, suas relações entre tempo e estoque na produção e nas distribuições em aspectos de controle de materiais. A logística incorpora dois principais subsistemas de atividades logísticas: A administração de materiais e transporte/ distribuição física, cada um tem o envolvimento e o controle das movimentações e do gerenciamento da demanda de suprimentos. As indústrias tinham um conceito de procurar atender seus clientes no imediatismo. Desta forma era fácil identificar a má administração dos estoques tendo em vista o valor de capital parado em estoque, por muitas das vezes sofrendo com degradação do tempo ou até mesmo com perca de inovação de seus produtos. Ao ponto de vista dos operadores logísticos, as definições de armazenagem como uma gestão econômica do espaço necessário englobar todas as funções de localização dimensionamento de área, ou de arranjos físicos, recuperando o estoque, consistindo novos projetos, novas docas ou baias de atracação e configuração dos armazéns.

A armazenagem trata-se de procedimentos que visam à conservação e controle das mercadorias estocadas para posterior utilização e distribuição. Para a empresa, quanto maior for à agilidade, a facilidade de mobilização, a usabilidade do espaço de armazenagem e a movimentação dos itens necessários as suas produções, melhor será sua possibilidade de reduzir e eliminar desperdícios de tempo, espaço e dinheiro.

Para o autor Dias (1993), a influência dos equipamentos e sistemas para a armazenagem na produtividade industrial pode ser observada em todas as frentes, com métodos adequados para estocar matériaprima.

Breve história sobre a empresa JFL fios e cabos na qual foi feito estudo de caso, esta empresa está situada na cidade de Sorocaba/SP.

O Grupo JFL fios e cabos detêm todas as tecnologias de desenvolvimentos e fabricação, desde 1929, ano de sua fundação no Brasil, vem mantendo posição de liderança fornecendo soluções para cabos sistemas em todo o mundo.

Dividida em duas unidades de negócio Energia (cabos terrestres e submarinos para a transmissão de eletricidade e distribuição) e Telecomunicação - (cabos e fibras ópticas para transmissão de dados, imagens e voz e cabos convencionais em cobre), o Grupo JFL fios e cabos está presente em todos os continentes. A JFL fios e cabos está presente comercialmente em todo o Brasil e América Latina e conta com mais de 1.000 (mil) colaboradores. No Brasil, com 25\% (vinte e cinco) de marketing share, a empresa possui sete unidades Fabris localizadas em Santo André, Sorocaba (três fábricas), ambas no estado de São Paulo, Vila Velha e Cariacica, situadas no estado do Espírito Santo, e em Joinville, no estado de Santa Catarina.

A seguir será apresentado o objetivo sobre os ganhos de produtividade com as técnicas de armazenagem e estoque, este estudo de caso foi realizado na empresa JFL fios e cabos.

\subsection{PROBLEMÁTICA E QUESTÃO DE PESQUISA.}

A realidade é que ainda se perde muito tempo no abastecimento nas linhas de produção isso traz atrasos na produtividade das matérias ou produtos.

A empresa JFL fios e cabos, que atua no mercado de fios e cabos de energia e fibras ópticas, os problemas com atrasos são devido á demora da busca de determinadas bobinas que encontra em estoque, este estoque é organizado por tamanho de bobinas, porém não consegue preparar alguns pedidos em um tempo que a empresa acredita ser ideal.

Colocado a situação problema elabora-se a seguinte questão de pesquisa: O que poderá ser feito para conseguir preparar os pedidos 
no prazo ideal, maximizando espaços e minimizando custos com estoques obsoletos?

\subsection{HIPÓTESE}

O estudo de caso realizado na Empresa JFL CABOS, pode ser observado que as máquinas que repassa o material de classe "A", material no qual tem uma rotatividade maior, deveriam ficar em local mais próximo do estoque facilitando assim a movimentação destas bobinas.

Este processo de colocar o material de classe "A" logo na entrada do seu estoque facilitaria na movimentação, a fim de, melhor atender os clientes internos e na agilidade para carregamentos. Isso faz com que a empresa minimize seus custos com movimentações desnecessárias e mão de obras para desempenhar estes movimentos.

\section{JUSTIFICATIVA}

É de extrema importância o crescimento e desenvolvimento das empresas e com mudanças na área logística, possibilita que o profissional desta área esteja sempre à procura de aperfeiçoar métodos.

Aplicando o método que será proposto nesse trabalho, pode-se analisar um ganho no preparo dos pedidos no tempo ideal, o qual evitará movimentação em excesso do material que esta no final do Estoque, evitando quebra de bobinas e avarias no material.

Agilizando todo o processo logístico, desde a entrada (input) até a saída (output) material, otimizando toda movimentação e alcançando índices e metas desejadas.

Nesta pesquisa será apresentado o conceito de logística, sistemas de informações, Supply Chain Management, armazenagem e estoque, este estudo se inicia na empresa JFL Fios e Cabos.

\subsection{OBJETIVO GERAL}

O objetivo deste estudo de caso é analisar a viabilidade de possíveis ganhos, aplicando conceitos de armazenagens e administração de materiais nas empresas. Maximizar o uso dos espaços de armazéns.

\subsection{OBJETIVO ESPECÍFICO}

- $\quad$ Estratégias para avaliar e organizar a estrutura dos produtos com a execução da produção, complementando as informações em sistemas computacionais.

- Identificar as políticas de estoques da empresa a ser estudada.

- Quais tipos de sistemas podem estar contribuindo para a confiabilidade da gestão de estoque na empresa.

\subsection{METODOLOGIA}

A metodologia utilizada para a elaboração desse trabalho será o estudo de caso e pesquisa bibliográfica, segundo o autor (GIL, 2008) a pesquisa bibliográfica e o estudo de caso são desenvolvidos com base em material já elaborado, constituído principalmente de livros e artigos científicos, monografias, dissertação de mestrado, tese de doutorado.

Nesta pesquisa foi utilizado de: bancos de dados tais como CAPS e CIASA, Revistas eletrônicas, artigos, dissertações, livros e teses, além de acesso a internet em simpósios e congressos.

Foi realizado também entrevistas com consultores especialistas, Doutores e Professores na área logística, o instrumento utilizado na elaboração pelo pesquisador com um questionário, este questionário contém perguntas abertas e fechadas.

\section{REFERENCIAL TEÓRICO}

A logística muito antes de ser estudada e considerada no ambiente empresarial, ela já estava em destaque no ambiente militar, sendo utilizada para posicionar as tropas e todos os suprimentos necessários durante as batalhas. Com mais de uma década, muito antes do mundo dos negócios interessarem se pelo assunto, os militares haviam executado aquela que foi chamada de mais sofisticada e mais bem planejada operação logística da história (BALLOU,1993).

Estima-se que no Brasil os gastos com as atividades logísticas correspondem em cerca de $17 \%$ do PIB, com base no fato de que os gastos com transporte correspondem com $10 \%$, e que na média o transporte corresponde a $60 \%$ dos custos logísticos. 
(FLEURY et. al. 2000 apud MAXWELL, 2015, p. 18),

O interesse está em compreender como certas empresas utilizam suas competências logísticas e se superam para obterem vantagens competitivas (BOWERSOX E CLOSS, 2007).

"Essa iniciativa irá forçar os fornecedores a inovar, com base em forte relacionamento um para um que irá conduzir maneiras mais inteligentes de implementar as tarefas". (ATTARAN E ATTARAN, 2007 apud MAXWELL, 2015, p.20).

Os autores destacam ainda que uma base sólida de informações exige investimentos no nível transacional, para se obterem redução nos investimentos em níveis mais alto. Nesse nível os custos são relativamente bem definidos e exibem um grau mais elevado de certeza no que se refere a vantagens ou retornos (BOWERSOX E CLOSS, 2001).

\section{A adoção progressiva das tecnologias de informação trouxe uma importante contribuição ao desenvolvimento das operações logísticas, na medida em que proporcionou o grau de flexibilidade necessário para a evolução do processo logístico por sucessivas fases de integração. (FIGUEIREDO, 2004 apud MAXWELL, 2015, p. 22).}

Nos últimos anos o mundo dos negócios tem enfrentado sérios desafios decorrentes das mudanças industriais e tecnológicas. Deste modo os sistemas de informações logísticos (SIL), apoiados pela área de $\mathrm{TI}$, assumem papéis importantes no aumento da competitividade logística de uma empresa, na medida em que permite a coletar, armazenar, disseminar e processar dados com relativa efetividade e rapidez.

No entanto, para entender melhor os SIL, faz se necessário de antemão entender o conceito por traz dos termos mais primários tais como: os dados e informações.

Dado é um conjunto de fatos organizados que adquiram valor adicional além do fato em si, ou seja, o que trafega dentro dos SI são dados e não informações, pois de forma genérica, a tecnologia computacional trabalha com código binário, o que caracteriza os SI como manipulador de dados, e não de informações. Os SI são conjuntos de partes integradas e dependentes entre si, trabalham com os objetivos comuns, utilizando os recursos computacionais.

A partir dos anos 90 em um conceito de Just in Time, com novas tecnologias inseridas nos sistemas eletrônicos e principalmente nos computadores.

\section{A tecnologia RFID (Radio-Frequency} IDentification, que em português significa Identificação por radiofrequência), é o facilitador ideal para ajudar a monitorar o movimento de produtos de suprimentos inspecionar e analisar os dados recolhidos a partir de etiquetas RFID, agir de acordo com os dados e potencialmente, adicionar ou associar mais dados úteis para etiquetas que podem ser utilizadas nos elos seguintes da cadeia. (BHUPTANI E MORADPOUR, 2005 apud MAXWELL, 2015, p. 22).

A tecnologia RFID abriu as portas para uma nova era na logística. Pontualmente, no caso específico de depósitos, armazéns e grandes centros de distribuição (CD), os sistemas de gerenciamento conhecidos como WMS (Warehouse Management System) podem ser considerados uma boa alternativa para otimizar a atividade de armazenagem, já que buscam maneiras de otimizar espaços e organizar o fluxo e a distribuição dos produtos. Também são encontradas outras tecnologias usadas nas empresas tais como: O ERP dispõe de um conjunto de programas capazes de interligar os aspectos da manufatura e incorporar os procedimentos contábeis ou dados gerados por outros aplicativos.

O ERP possibilita um fluxo de informações único, contínuo e consistente por toda a empresa sob uma única base de dados.

Este novo enfoque pode ser percebido até em revistas especializadas de administração e negócios, revistas e periódicos de interesse geral em toda a mídia escrita e falada, nunca o termo e os problemas de Logística foram tão atuais. (DIAS, 1995).

As bibliografias de Ballou (1993 e 2001), Bowersox (2001 e 2014) e Chopra (2003), também foram referências nos termos relacionados à logística e sua missão: entregar corretamente um recurso no local e momento certo, na quantidade exata, na condição ideal e ao custo planejado.

Considera-se hoje a gestão de estoque fundamental para o sucesso organizacional e por meio do processo de estocagem que se 
pode tirar proveito na ocupação do espaço, na utilização de recursos operacionais, na otimização do tempo do pessoal e no processo de separação de pedidos (BANZATO ET AL, 2003).

Para Venanzi e Silva (2013), a decisão de estocar ou não determinado item é básico para o volume de estoque em qualquer momento. Ao se tomar uma decisão, há dois fatores a considerar: 1ํ É econômico estocar o item; $2^{-}$É interessante estocar um item indicado como antieconômico a fim de satisfazer um cliente e, portanto, melhorar as relações com ele.

Ainda para Venanzi e Silva (2013) quanto mais estoque, maiores são: custo de aluguel; manuseio; pessoas e equipamentos.

Segundo os autores Martin e Alt (2006) é necessária uma análise detalhada dos estoques não somente em decorrência dos volumes de capital envolvidos, mas principalmente pela vantagem competitiva que a empresa pode obter em rapidez e precisão no atendimento aos clientes.

O estoque agrega valor de tempo ao produto, pois envolve a disponibilidade do mesmo a ser entregue para o consumidor final.

Estocagem e armazenagem são duas palavras muito confundidas, tanto em suas definições quanto na pratica. A matéria-prima e materiais são guardados em ordem de prioridade de uso e também peças que serão utilizadas na montagem dos produtos, sendo definida assim, a estocagem. Já armazenagem são todos os produtos acabados estocados na própria fabrica ou que serão distribuídos, também separados de forma ordenada.

\subsection{CURVA ABC}

A curva $A B C$, também chamada de análise de Pareto ou regra 80/20, é um método de categorização de estoques, cujo objetivo é determinar quais são os produtos mais importantes de uma empresa. Foi desenvolvido pelo consultor de qualidade romeno-americano Joseph Moses Juran, que verificou que $80 \%$ dos problemas são geralmente causados por $20 \%$ dos fatores. O nome "Pareto" é uma homenagem ao economista italiano Vilfredo Pareto, que em um estudo observou que $80 \%$ das riquezas são concentradas nas mãos de $20 \%$ da população, sendo que boa parte do entendimento da curva $A B C$ se deve a esse estudo de Pareto.

Segundo Carvalho (2002, p. 226) curva ABC é "um método de classificação de informações, para que se separem os itens de maior importância ou impacto, os quais são normalmente em menor número".

Trata-se de classificação estatística de materiais, baseada no princípio de Pareto, em que se considera a importância dos materiais, baseada nas quantidades utilizadas e no seu valor. Também pode ser utilizada para classificar clientes em relação aos seus volumes de compras ou em relação à lucratividade proporcionada; classificação de produtos da empresa pela lucratividade proporcionada, etc.

No que diz respeito à análise de clientes, a curva $A B C$ serve para analisar a dependência ou risco em face de um cliente, ou ainda para que tipo de clientes a organização se deve focar. Consiste em ordenar os clientes por ordem decrescente da sua contribuição para a empresa, de modo a se poder segmentar por grau de dependência, de risco ou ainda por outro critério a definir.

Numa organização, a curva $A B C$ é muito utilizada para a administração de estoques, mas também é usada para a definição de políticas de vendas, para o estabelecimento de prioridades, para a programação de produção, etc. Para a administração de estoques, por exemplo, o administrador usa como um parâmetro que informa sobre a necessidade de aquisição de itens mercadorias ou matérias-primas - essenciais para o controle do estoque, que variam de acordo com a demanda do consumidor.

$\mathrm{Na}$ avaliação dos resultados da curva ABC, percebe-se o giro dos itens no estoque, o nível da lucratividade e o grau de representação no faturamento da organização. Os recursos financeiros investidos na aquisição do estoque poderão ser definidos pela análise e aplicação correta dos dados fornecidos com a curva ABC (PINTO, 2002, p. 142).

\subsubsection{PARÂMETROS DE OBSERVAÇÃO DA CURVA ABC}

A curva $A B C$, no caso de administração de estoques, apresenta resultados da demanda de cada item nas seguintes áreas: 
- Giro no estoque;

- Proporção sobre o faturamento no período;

- Margem de lucro obtida.

Os itens são classificados como:

de Classe A: de maior importância, valor ou quantidade, correspondendo a $20 \%$ do total (podem ser itens do estoque com uma demanda de 65\% num dado período);

de Classe B: com importância, quantidade ou valor intermediário, correspondendo a 30\% do total (podem ser itens do estoque com uma demanda de 25\% num dado período);

de Classe C: de menor importância, valor ou quantidade, correspondendo a $50 \%$ do total (podem ser itens do estoque com uma demanda de 10\% num dado período). (CARVALHO, 2002, p. 227).

Os parâmetros acima não são uma regra matematicamente fixa, pois podem variar de organização para organização nos percentuais descritos. A definição das classes A, B e C obedece apenas a critérios de bom senso e conveniência dos controles a serem estabelecidos e é definida pelo gestor.

O que importa é que a análise destes parâmetros propicia o trabalho de controle de estoque do analista cuja decisão de compra pode se basear nos resultados obtidos pela curva $A B C$. Os itens considerados de Classe A merecerão um tratamento preferencial. Assim, a consequência da utilidade desta técnica é a otimização da aplicação dos recursos financeiros ou materiais, evitando desperdícios ou aquisições indevidas e favorecendo o aumento da lucratividade.

\subsection{MELHORIA CONTÍNUA}

$\mathrm{Na}$ maioria das empresas, atualmente a melhoria contínua e a sua implementação estão na ordem do dia. Criam-se departamentos de melhoria contínua, contratam-se empresas de consultoria para ajudar a desenvolver projetos e a implementálos, e na realidade na maioria dos projetos conseguem-se ganhos significativos e mensuráveis. Mas os projetos normalmente terminam e ao final de algum tempo as alterações realizadas com a implementação começam a perder-se e os hábitos de trabalho voltam a ser os tradicionais.

Os 12 princípios da melhoria contínua são: 1). Os problemas são oportunidades de aprendizagem. 2). Vá e veja por si (observar as dificuldades da equipe para tomar decisões). 3). Procurar a causa raiz. 4). Corrigir os erros logo que acontecem. 5). Usar a cabeça e não a carteira (avaliar investimentos, nem sempre o mais barato é o melhor). 6). Optar pela solução mais simples e não pela perfeita. 7). Não subestimar a inteligência e conhecimento dos outros. 8). Trabalhar em equipe. 9). Evitar desculpas, assumir os erros. 10) Ser Proativo. 11) A melhoria contínua implica mudança contínua. 12) A melhoria contínua não tem fim, deve-se criar a cultura da melhoria contínua.

As organizações de hoje enfrentam um ambiente cada vez mais dinâmico e inovador, de modo que essa condição exige uma adaptação às novas práticas de trabalho. A competição e a evolução tornaram o conhecimento e o tempo importantes diferenciais competitivos para a empresa. 0 conhecimento das organizações é o seu ativo mais importante, ainda que não seja contabilizado nos sistemas de informação econômico-financeiros tradicionais. (MACHADO; FRANCISCO, 2005, P. 2).

Na visão de Oliveira (2014) os 12 princípios da melhoria contínua estão representados na Figura 1. 
Figura 1:

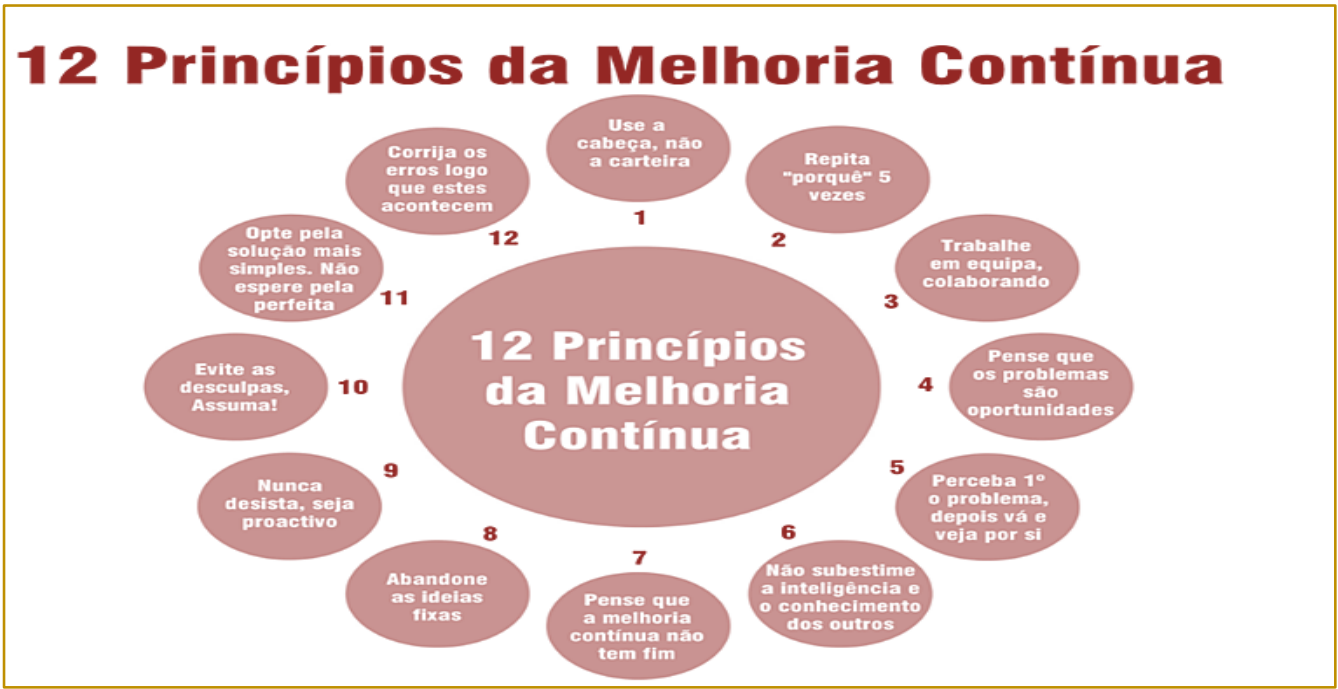

Fonte: (Oliveira, 2014) http://www.uffj.br/ep/files/2014/07/2013_3_Jane.pdf

\section{RESULTADOS E DISCUSSÃO}

Um ganho no preparo dos pedidos no tempo ideal, o qual evitará movimentação em excesso do material que está no final do Estoque, evitando quebra de bobinas e avarias no material.

Agilizando todo o processo logístico, desde a entrada até a saída do material, otimizando toda movimentação e alcançando índices e metas desejadas. Partindo do princípio, a aplicação do senso da utilização, foi observado à otimização do uso do espaço, JFL fios e cabos é uma empresa de grande porte, seu espaço tendo que ser bem aproveitado.

\section{REFERÊNCIAS}

[1] Ballou, R H. Gerenciamento da Cadeira de suprimentos: planejamento, organização e logística empresarial. 4aㅡ edição. Porto Alegre: Bookman, 2001.

[2] Banzato, E.; et al. Atualidades na Armazenagem. 1. ed. São Paulo: 2003.

[3] Bowersox, D. J.; Closs, D. J. Logística Empresarial: o processo de integração da cadeia de suprimento. São Paulo: Editora Atlas, 2001.

\section{CONSIDERAÇÕES FINAIS}

No estudo de caso feito na empresa JFL fios e cabos, observa-se que as técnicas de Classificação ABC ajudaram a aumentar a produtividade.

Antes o colaborador fazia 20 cortes de cabos em bobinas em 8 horas trabalhadas, e depois das técnicas $A B C$ o colaborador faz 35 cortes de cabos em bobinas nas mesmas 8 horas.

Esses resultados foram conseguidos com os itens Classe A, mais próximos das maquinas de corte, assim facilitando e agilizando processo de corte de cabos, pois esses materiais classe A tem maior saída, evitando movimentação desnecessária que causava quebras de bobinas e danos a cabos caros, além da busca no estoque ser mais rápida.

Houve ganhos no layout em função da classificação $A B C$, estando agora o layout bem organizado.

[4] Bowersox, D. J., Closs, D.; J., Cooper, M. B. Gestão logística de cadeias de Suprimentos. Porto Alegre: Bookman, 2006.

[5] Carvalho, J. M. C. de - Logística. 3aㅡ ed. Lisboa: Edições Silabo, 2002.

[6] Chopra, S.; Meindl, P. Gerenciamento da Cadeia de suprimentos: Estratégia, Planejamento e Operações. São Paulo: Pearson, 2003.

[7] Dias, M. A. P. Administração de materiais: Uma abordagem logística. 4. ed. São Paulo: Atlas, 1993. 
[8] Dias, M. A. P. Administração de materiais: Uma abordagem logística. 4. ed. (Edição compactada), 1995.

[9] GIL. R. L. Tipos de pesquisa. Licenciatura em ciências biológicas, disciplina de pesquisa do ensino de ciências e biologia, 2008. Disponível em: http://wp.ufpel.edu.br/ecb/files/2009/09/Tipos-dePesquisa.pdf Acesso: 03 Abr. 2018

[10] Machado, R.; Francisco, A. C. Melhoria contínua como ferramenta para o aumento da competitividade organizacional: um estudo de caso no setor metal metalúrgico. Bauru. 2005. Disponível em:file:///C:/Users/Home/Downloads/Machado_R_M elhoria\%20Continua.pdf Acesso em: 03 Abr. 2018.

[11] Martin, P. G.; ALT, P. R. C. Administração de materiais e recursos patrimoniais. 2.ed.São Paulo:Saraiva.2006. p.441.

[12] Maxwell. Artigo. PUC Rio. 2015. Disponível em:https://www.maxwell.vrac.puc-
rio.br/13795/13795_3.PDF Acesso em: 05 Abr. 2018.

[13] Oliveira, J. A. Terceirização da logística: Um estudo de caso na indústria de cosméticos. Universidade Federal de Juiz de Fora, MG. 2014. Disponível em:http://www.ufjf.br/ep/files/2014/07/2013_3_Jane. pdf Acesso em: 20 Out. 2017.

[14] Pinto, C. V. - Organização e gestão da manutenção. 2ª ed. Lisboa: Edições Monitor, 2002.

[15] Venanzi, D.; SILVA, O. R. Arranjos de condomínio industrial e consórcio modular na indústria automobilística brasileira: uma análise de múltiplos casos. SIMPOI 2010, ANAIS. Disponível em:

http://www.simpoi.fgvsp.br/arquivo/2010/artigos/E2 010_T00056_PCN87678.pdf Acesso em: 18 Out. 2017 


\section{Capítulo 19}

\section{PROCESSOS CRITICOS NA CADEIA DE SUPRIMENTO - IMPACTO CLIMÁTICO NO PERIODO SAZONAL NA PRODUÇÃO DA LARANJA E EXPORTAÇÃO: ABORDAGEM DA TEORIA DA RESTRICÃO (TOC)}

\section{Barbara Soares da Silva \\ Heberty da Silva \\ Leticia Perez da Silva \\ Renata dos Santos de Andrade}

Resumo: Um dos Objetivos deste artigo é tratar as principais dificuldades na exportação do suco de laranja para os Estados Unidos, delimitando a pesquisa no período de sazonalidade que transcorre nos meses de outubro a fevereiro. Como modelo teórico iremos abordar a Teoria das Restrições (TOC). Constitui-se como modelo de pesquisa o entendimento e o comportamento da produção de laranja Citrus Sinensis mais conhecida como laranja pêra. Esta pesquisa se estrutura em base de referências Unicamp (Avaliação das fragilidades entre a produção agrícola da laranja e o setor industrial), utilização da métrica com embasamento teórico em artigos econômicos e órgãos oficiais. Este trabalho tem como foco central direcionar saídas para melhorar os processos na sua alta temporada de safra, período este que toda a cadeia sofre impacto por conta de modificações climáticas e erros no gerenciamento da cadeia de suprimentos. Do ponto de vista prático, observamos a hegemonia do Brasil nesse mercado, que mesmo com as quedas na produção, barreiras criadas para frear as exportações de Suco de laranja que é uma das principais commodities que o mercado Brasileiro opera. Existe um forte indício de recuperação e crescimento no setor, considerando que o Brasil é o maior produtor mundial de suco de laranja e que qualquer movimento neste setor altera de forma significativa todo o mercado financeiro mundial. Delimitamos a pesquisa em mostrar os impactos na produção por motivos naturais como modificações climáticas, pragas nas plantações mesmo com uso de produtos químicos, falta de qualidade no solo e barreiras na exportação.

Palavras-chave: Exportação, Logística, Comércio, Supply Chain. 


\section{1- INTRODUÇÃO}

A pesquisa apresentada neste artigo tem como objetivo chave abordar os processos críticos na cadeia de suprimento na exportação do suco de laranja para os Estados Unidos, delimitando dentro do tema principal uma abordagem do papel do gestor. Com base na problemática citada neste artigo os principais impactos na produção de laranja por motivos naturais como modificações climáticas, pragas nas plantações mesmo com uso de produtos químicos, falta de qualidade no solo e barreiras na exportação, o gestor tem o papel fundamental na tomada da situação, e quando esta decisão é sistematizada conforme as abordagens apresentadas e descritas, à gestão se torna mais assertiva. Uma proposta é a teoria das restrições que parte do pressuposto de que toda entidade possui uma restrição que limita o desempenho de suas atividades no alcance de suas metas, tendo em vista que a meta principal de toda empresa é a lucratividade e que se não existissem as limitações os ganhos seriam infinitos. Segundo Guerreiro (1996), expõe que existem dois tipos de restrições: a primeira é a física, "engloba mercado, fornecedor, máquinas, materiais, pedido, projeto, pessoas e é denominada de restrição de recurso", e a segunda é a restrição política, "formada por normas procedimentos e práticas usuais do passado". A pesquisa esta baseada na exportação do suco de laranja para o mercado internacional, a delimitação desta abordagem se baseia no mercado Brasileiro exportando para o Mercado Norte Americano. Foi identificado no Brasil que no período anual existem tipos de laranjas que sofrem menos impactos climáticos que outras, por outro lado a pesquisa também informa que para determinada categoria de laranja existe um período de safra.

Na produção da laranja existem pelo menos três momentos, iremos abordar neste o conceito de cada fase, focando o assunto em "Safra". De acordo com o professor e Dr. Luiz Felippe Salemi formado em Gestão ambiental e com pós-doutorado na área de hidrologia e ecologia de ecossistemas, em um de seus artigos publicados é abordado que normalmente os agricultores aproveitam do solo e clima durante todo um ciclo.

\section{2 - EMBASAMENTO TEÓRICO E REVISÃO DA LITERATURA}

\section{1 - FUNDAMENTAÇÃO DA TEORIA DAS RESTRIÇÕES}

A teoria das restrições foi originalmente desenvolvida por Eliyahu Goldratt, um físico israelense que publicou os fundamentos no seu livro A Meta. Goldratt introduziu o termo teoria das restrições ("Theory of Constraints" TOC) em 1987 englobando vários conceitos como o sistema de gerenciamento de desempenho, os cinco passos para melhoria contínua, refinamentos de conceitos de como gerenciar a produção e outras áreas de uma empresa. Existem duas premissas em sua abordagem. A primeira é considerar a organização como um sistema cujo sucesso ou fracasso depende da forma como diferentes processos interagem entre si. A segunda é a de que uma restrição é qualquer coisa que limite o sistema de atingir sua meta. Segundo Goldratt (1990) todo sistema deve ter pelo menos uma restrição ou fator limitante. Uma restrição não é boa nem má. Ela existe e deve ser gerenciada. De fato, o reconhecimento da existência de um fator limitante é uma excelente oportunidade para a melhoria, pois permite o foco na identificação e gerenciamento das restrições.

De acordo com Silver, Pyke e Peterson (2002) numa empresa industrial, a TOC envolve três indicadores de desempenho que permitem avaliar se o conjunto das operações está se movendo em direção aos objetivos (lucro).

\subsection{RENTABILIDADE}

Segundo Sytsma, S.,(2003) é a taxa pela qual a empresa constrói seu lucro através da comercialização de seus produtos. Em essência, a rentabilidade de um produto poderia ser aproximada pela margem de contribuição (preço de venda - custo variável das matérias-primas). Os custos de mão de obra e outros custos fixos são considerados como parte das despesas operacionais.

\subsection{DESPESAS OPERACIONAIS}

De acordo com Sytsma, S., (2003) é todo o dinheiro gasto pela empresa na conversão de seus estoques em margem de contribuição. 


\subsection{ESTOQUES}

Em Sytsma, S., (2003) é todo o dinheiro imobilizado pela empresa em coisas que podem ou poderiam ser comercializadas. Os estoques incluem não apenas os itens convencionais (matérias-primas, produtos em processamento e produtos acabados), mas também edifícios, terras, veículos, equipamentos. Não é incluído nos estoques, portanto, o valor do trabalho adicionado aos estoques dos produtos em processamento.

\section{COMMODITIES}

Commodities são produtos "in natura", cultivados ou de extração natural, que podem ser estocados por um certo tempo sem perda das suas qualidades, como por exemplo, o suco de laranja congelado. São como um todo uma forma de investimento, onde se dão através do Mercado de futuros, como BM\&F Brasileira, as bolsas de Chicago, New York, atuando da seguinte maneira: o investidor compra no mercado de futuros um contrato com um grande produtor de laranjas, estipulando que ele se comprometa a entregar daqui a sete meses 400 toneladas de laranjas, pelas quais você se compromete a pagar $\mathrm{R} \$ 140,00$ por tonelada. Nessa transação você espera poder vender esse contrato de laranjas para algum interessado, antes da sua data de vencimento, por um preço maior por tonelada do que pagou, obtendo lucro na transação.

Suco de Laranja NY Futuros - Mai 18

\begin{tabular}{|c|c|c|}
\hline \multicolumn{3}{|c|}{ Cotação de Suco de laranja - Bolsa de Nova York } \\
Contrato & Fechamento (c/US\$/libra peso) Variação & Pontos \\
\hline Maio/18 & 137,45 & 0,30 \\
\hline Julho/18 & 138,45 & 0,30 \\
\hline Setembro/18 & 139,30 & 0,30 \\
\hline
\end{tabular}

Fonte: INO.com

\subsection{IN NATURA}

In Natura Suco de laranja concentrado e congelado é bombeado para os tanques de alimentação dos evaporadores, onde é retirada grande parte do conteúdo de água, até que o suco atinja teor de sólidos solúveis totais de aproximadamente $65^{\circ}$ Brix.

Na saída do evaporador o suco concentrado passa pelo resfriador de expansão (flash cooler) de onde é bombeado na temperatura de $15-20^{\circ} \mathrm{C}$ para os tanques de mistura e homogeneização (tank blender). Nos tanques de mistura e homogeneização realiza-se a adição de óleo essencial e/ou essências (fases aquosa e oleosa) e/ou mistura de outros sucos. O suco de laranja concentrado, resfriado e homogeneizado tem sua temperatura reduzida a $-10^{\circ} \mathrm{C}$ através de trocadores de calor, sendo enviado aos tanques de estocagem de grande capacidade (tank farm), instalados em câmaras frigoríficas a $-10^{\circ} \mathrm{C}$, ou para $\mathrm{O}$ acondicionamento. O suco de laranja concentrado e congelado pode ser acondicionado em sacos plásticos contidos em tambores metálicos de 200 litros ou envasado assepticamente em sacos metalizados de multicamadas, com ou sem sistemas de resfriamento acoplados. De acordo com Chen (1993) e Queiroz e Menezes (2005) o suco de laranja concentrado, congelado e embalado é colocado em embalagens de distribuição (pallets) e enviado para câmaras frigoríficas com temperatura entre $-26^{\circ} \mathrm{C}$ e $-20^{\circ} \mathrm{C}$. Segundo Nagy (1980) e Shaw (1993) o suco concentrado e congelado pode permanecer nas câmaras frigoríficas até o transporte para o porto de embarque, de onde é enviado para os compradores e posterior processamento e comercialização do produto. O suco concentrado e congelado possui extensa vida-de-prateleira, mas pode perder atributos de qualidade durante seu processamento e estocagem.

A exportação de suco de laranja do Brasil, maior exportador global, encerrou a temporada 2016/17 (julho/junho) no menor nível em mais de 25 anos. O setor esta sofrendo o impacto de uma quebra acentuada de safra..A queda neste período foi de quase $19 \%$ na oferta da laranja. Este resultado causou impacto direto na balança 
comercial brasileira, uma queda de 18,6\% em um mercado que em 2016 movimentou 1,274 Bilhão, 2017 fechou sua receita total com 1,148 Bilhão. Queda esta que não passou despercebida a os olhos dos investidores deste setor.

\section{IMPACTO NA PRODUÇÃO DE LARANJA}

- A produção agrícola ocorre ao longo de um ano que não necessariamente coincide com o início em janeiro e fim em dezembro. Para os agricultores, dependendo da cultura que eles plantam, o ano pode se iniciar em qualquer mês do ano e não obrigatoriamente em janeiro como estamos acostumados este período é conhecido como safra.

- Na entressafra o solo fica sem atividade agrícola, o que faz com que alguns agricultores plantem algumas culturas anuais de ciclo curto que consigam desenvolver-se nesse período com as condições climáticas menos favoráveis à cultura principal. Assim, o agricultor consegue cultivar a terra plantando outra cultura o que traz uma renda extra a ele por meio da comercialização dessa cultura plantada nas entressafras.

- O produto obtido neste período é chamado de safrinha Vale colocar que para a obtenção da safrinha, alguns agricultores tentam antecipar a época de plantio da cultura principal de modo que a colheita, em função disso, também seja adiantada.

No ano de 2018 foi identificado pela Usda (United States Department of Agriculture) órgão público que cuida da agricultura nos Estados Unidos, que no ano de 2018/19 haverá uma queda de 15\% em relação o ano de 2017.

Alguns motivos identificados foram estresse nas árvores que tendem a fazer com que seja colhido um volume menor de frutas no ano seguinte, florada da safra 2018/19 foi parcialmente danificada pelo tempo seco que prevaleceu em setembro, particularmente no norte das regiões de produtivas. Em contra partida a USDA fez uma revisão destes números, uma segunda florada ocorreu recentemente em quase todas as regiões em desenvolvimento, por causa do aumento no tamanho das frutas cultivadas na área comercial de São Paulo e no oeste de Minas
Gerais, partindo de 471 milhões de caixas, para 500 milhões de caixas mesmo numero produzido em 2017.

Com maior disponibilidade de frutas, a produção total de suco de laranja considerando o concentrado e congelado (FCOJ) e o não concentrado e não congelado (NFC) está estimada em 1,372 milhão de toneladas na safra de $2017 / 18$, crescimento de $59,7 \%$ ante $2016 / 17$. Na mesma linha, as exportações do período devem bater 1,255 milhão de toneladas, avanço de 30,4\% em comparação com a temporada passada. Segundo o USDA, parte da elevação nos embarques se deve ao aumento nas compras dos Estados Unidos, após a passagem do furacão Irma, neste ano, que afetou a produção americana da Flórida. Para 2018/19, a expectativa é que a fabricação brasileira de suco de laranja alcance 1,152 milhão de toneladas, redução de $16 \%$. Já as exportações devem diminuir 9,4\% no período, para 1,137 milhão de toneladas. Deixamos claro neste capitulo que qualquer variação na produção, gera grande impacto financeiro na balança comercial, afetando de forma significante $\mathrm{o}$ mercado interno e principalmente o mercado externo, já que temos os EUA (Estados Unidos) como um dos nossos principais clientes.

\section{BARREIRAS NATURAIS NO CULTIVO DE CITRUS SINENSIS}

- Ideal para o plantio da laranjeira e outros citros, que preferem climas com temperatura entre 23 e $32{ }^{\circ} \mathrm{C}$ e umidade relativa do ar alta. Acima de $40{ }^{\circ} \mathrm{C}$ e abaixo de $13{ }^{\circ} \mathrm{C}$, a taxa de fotossíntese diminui o que acarreta perdas de produtividade. Os frutos produzidos nos climas mais frios, em geral, são mais ácidos e apresenta coloração da casca e do suco mais intensa, nos climas mais quentes os frutos são mais doces.

- Em São Paulo existe uma pluviosidade significativa ao longo do ano. Mesmo o mês mais seco ainda assim tem muita pluviosidade. O clima é classificado como Cfb de acordo com a Köppen e Geiger. Em São Paulo a temperatura média é $18.5^{\circ} \mathrm{C}$. $1340 \mathrm{~mm}$ é o valor da pluviosidade média anual. Como mostraremos nas imagens a seguir: 
Figura 1 - Tabela Climática - São Paulo

\begin{tabular}{|c|c|c|c|c|c|c|c|c|c|c|c|c|}
\hline & Janeiro & Fevereiro & Março & Abril & Maio & Junho & Julho & Agosto & Setembro & Outubro & Novembro & Dezembro \\
\hline $\begin{array}{l}\text { Temperatur } \\
\text { a média }\left({ }^{\circ} \mathrm{C}\right)\end{array}$ & 21.5 & 21.4 & 20.5 & 18.5 & 16.6 & 15.5 & 15.4 & 16.2 & 17.4 & 18.5 & 19.8 & 20.3 \\
\hline $\begin{array}{c}\text { Temper atur } \\
\text { a mínima } \\
\left({ }^{\circ} \mathrm{C}\right)\end{array}$ & 16.8 & 16.9 & 16 & 13.8 & 11.7 & 10.3 & 10 & 10.8 & 12.2 & 13.7 & 15.2 & 15.6 \\
\hline $\begin{array}{l}\text { Temperatur } \\
\text { a máx ima } \\
\left({ }^{\circ} \mathrm{C}\right)\end{array}$ & 26.2 & 26 & 25.1 & 23.3 & 21.5 & 20.8 & 20.8 & 21.7 & 227 & 23.4 & 24.5 & 25 \\
\hline $\begin{array}{l}\text { Temperatur } \\
\text { a média ( }\left({ }^{\circ} \mathrm{F}\right)\end{array}$ & 70.7 & 70.5 & 68.9 & 65.3 & 61.9 & 59.9 & 59.7 & 61.2 & 63.3 & 65.3 & 67.6 & 68.5 \\
\hline $\begin{array}{l}\text { Temperatur } \\
\text { a minima } \\
\left({ }^{\circ} \mathrm{F}\right)\end{array}$ & 62.2 & 62.4 & 60.8 & 56.8 & 53.1 & 50.5 & 50.0 & 51.4 & 54.0 & 56.7 & 59.4 & 60.1 \\
\hline $\begin{array}{l}\text { Temper atur } \\
\text { a máx ima } \\
\left({ }^{\circ} \mathrm{F}\right)\end{array}$ & 79.2 & 78.8 & 77.2 & 73.9 & 70.7 & 69.4 & 69.4 & 71.1 & 729 & 74.1 & 76.1 & 77.0 \\
\hline Chuva (mm) & 218 & 205 & 149 & 64 & 56 & 49 & 35 & 43 & 71 & 123 & 137 & 190 \\
\hline
\end{tabular}

Fonte: Climate-data.org

Quando comparados o mês mais seco tem uma diferença de precipitação de $183 \mathrm{~mm}$ em relação ao mês mais chuvoso. As temperaturas médias têm uma variação de $6.1^{\circ} \mathrm{C}$ durante o ano.

Figura 2 - Gráfico Temperatura - São Paulo

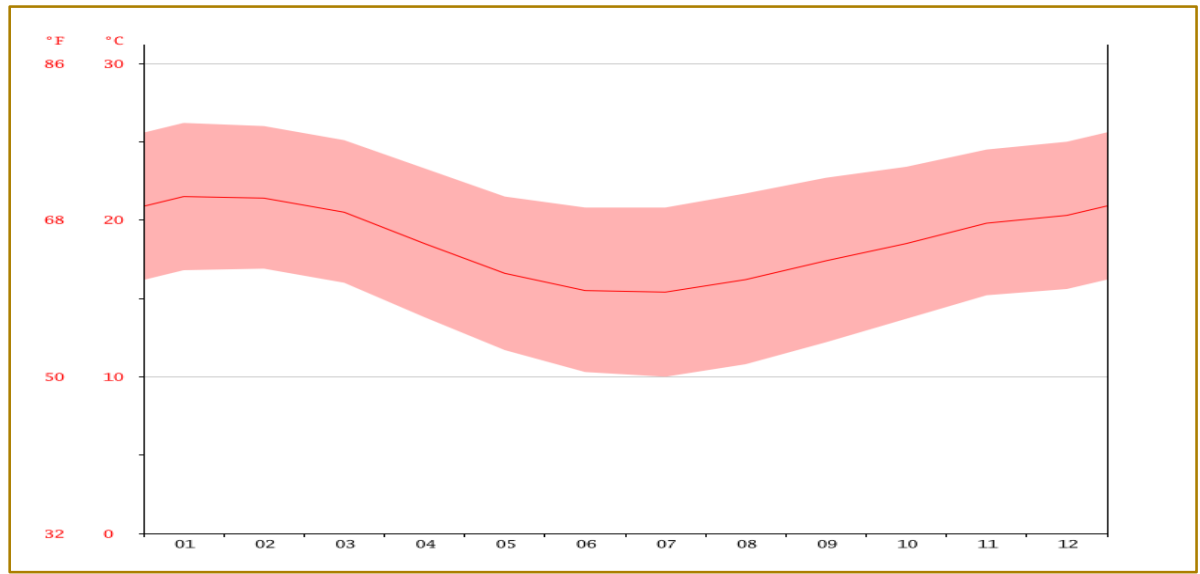

Fonte: Climate-data.org

$21.5{ }^{\circ} \mathrm{C}$ é a temperatura média do mês de Janeiro, o mês mais quente do ano. Ao longo do ano Julho tem uma temperatura média de $15.4^{\circ} \mathrm{C}$. É a temperatura média mais baixa do ano. 
Figura 3 - Gráfico Climograma: São Paulo

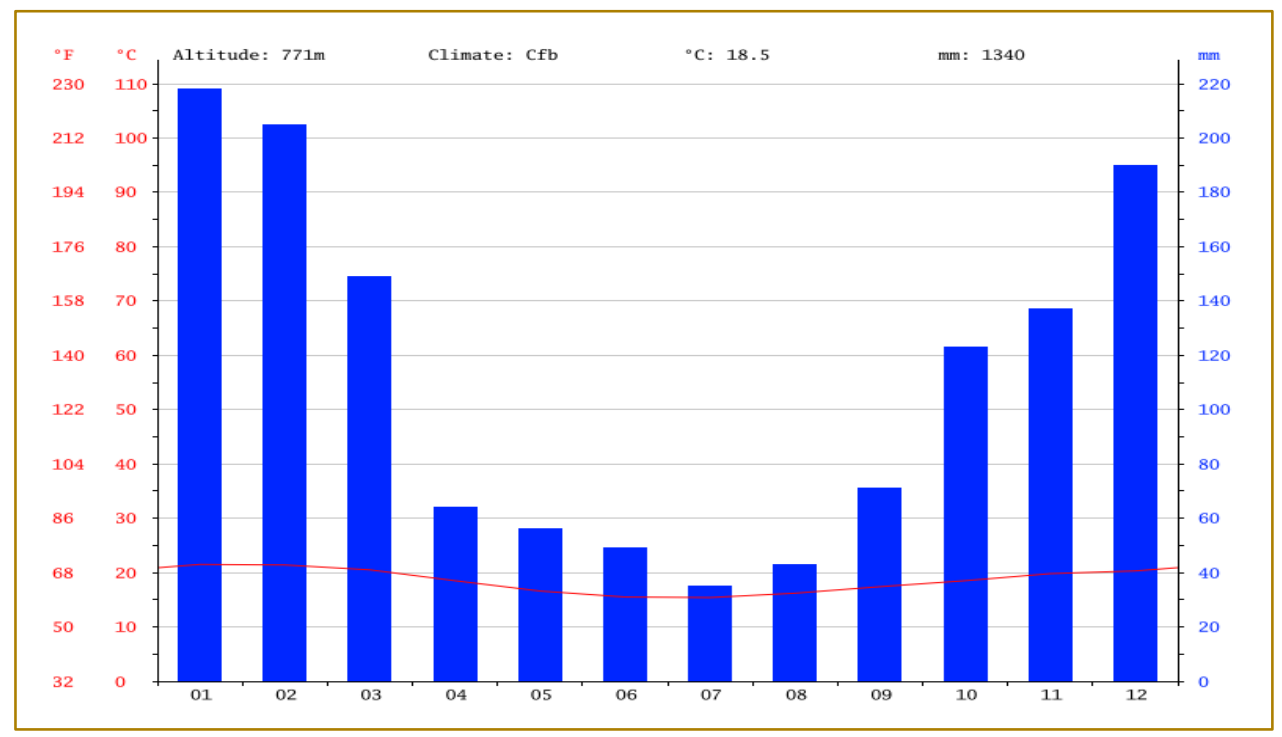

Fonte: Climate-data.org

$35 \mathrm{~mm}$ refere-se à precipitação do mês de Julho, que é o mês mais seco. Em Janeiro cai a maioria da precipitação, com uma média de $218 \mathrm{~mm}$.

- O Estado de São Paulo é o principal produtor nacional de laranja, com 691,26 mil hectares e produção de 368,2 milhões de caixas de 40,8kg, em 2007. Na atualidade, a atividade encontra-se distribuída de forma marcante em duas regiões: a tradicional, constituída pelos EDRs (Escritórios Regionais de Desenvolvimento Rural) de Araraquara, Barretos, Catanduva, Fernandópolis, General Salgado, Jaboticabal, Limeira, Mogi-Mirim, Ribeirão Preto, São João da Boa Vista, São José do Rio Preto e Votuporanga; e a região nova, constituída por Avaré, Bauru, Botucatu, Itapetininga, Itapeva, Jales, Jaú, Lins, Piracicaba e Sorocaba.

Ressalte-se que esta última tem contribuído para a instalação do parque citrícola, por reunir condições adequadas à atividade quanto aos aspectos edafo-climáticos e por ainda ser pouco susceptível às novas doenças (figura 1) (Informações Econômicas, SP, v.38, n.3, p.47-66, mar. 2008. 3VICENTE, M.C.M.; BAPTISTELLA, C.S.L.; FRANCISCO, V.L.F.S. Evolução do Mercado de Trabalho na Agropecuária Paulista, 1995-2004. IN: XLIII CONGRESSO BRASILEIRO DE ECONOMIA E SOCIOLOGIA RURAL, Ribeirão Preto, SP, Anais. Brasília, SOBER, 2005.)

Figura 4 - Mapa da Laranja - São Paulo

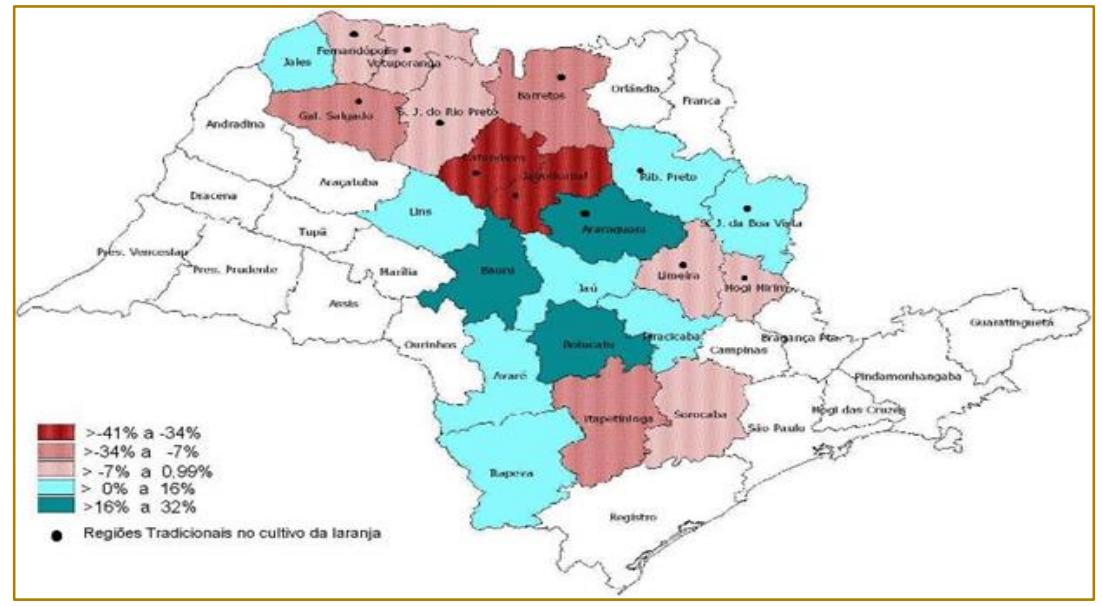

Fonte: Olivette; et al, 2006 


\section{6 - RESULTADOS E DISCUSSÃO}

Sendo assim conclui-se que um dos principais impactos em relação à produção de laranja, deve-se muito ao clima, conforme abordado, outro motivo identificado foi o estresse nas árvores que tendem a fazer com que seja colhido um volume menor de frutas no ano seguinte. O período de safra do ano de 2018/19 foi parcialmente danificada pelo tempo seco que prevaleceu em setembro 2017, particularmente no norte das regiões com produção de laranja. Em contrapartida nesta pesquisa observamos uma grande melhora nas novas plantações e que podem levar bons resultados para o mercado financeiro, pois uma grande florada que ocorreu recentemente em quase todas as regiões em desenvolvimento, proporcionou um aumento significativo do tamanho das frutas cultivadas na área comercial em São Paulo e oeste de Minas Gerais, havendo um aumento de 471 milhões de caixas para 500 milhões de caixas, mesmo volume produzido em 2017.

\section{7 - CONSIDERAÇÕES FINAIS}

De acordo com as teorias apresentadas notase que o clima é crucial durante todo o processo evolutivo do plantio, tornando-se assim o principal elemento para que os produtores de laranja consigam alcançar melhorias significativas quanto a produção do fruto. Com a intensificação no entendimento do problema os especialistas puderam diagnosticar novos fatores potencialmente prejudiciais ao cultivo e consequentemente novas soluções afim de mitigar esses ofensores, tais como, renovação das áreas de desenvolvimento, que possibilita a colheita do fruto com maior qualidade utilizando a mesma forma de plantio. É fundamental que os produtores saibam se adaptar as possíveis

\section{REFERÊNCIAS}

\section{[1]. GOLDRATT, 1990; 1994}

[2]. SILVER, EA; PYKE, DF; PETERSON, R. Inventory Management and Production Planning and Scheduling . 3. ed. New York: Wiley \& Sons, 1998. $784 \mathrm{p}$.

[3]. CHEN et al., 1993; QUEIROZ e MENEZES, 2005 / NAGY, 1980; SHAW, 1993

[4]. Informações Econômicas, SP, v.38, n.3, p.47-66, mar. 2008. 3VICENTE, M.C.M.; variações climáticas tendo em vista que não podemos controlá-las, ou seja, possuir alternativas para que o processo não seja interrompido ou paralisado por conta dessas variações.

Outro diagnostico importante foi a percepção de que os solos e árvores já estressados por conta do uso continuo, se tratados, podem voltar a desempenhar como no início de suas vidas. Sendo assim notou-se que o rodízio nos locais de plantio são benéficos a entrega do produto final, pois pode-se tratar o solo danificado enquanto o outro já recuperado produz frutos de boa qualidade. Além da metodologia utilizada na composição do trabalho, com métricas climáticas, seria de total proveito a criação de métricas sobre plantio e colheita, gerando informações que permitissem a evolução das novas safras.

Em um cenário em que o gestor não tem controle das mudanças climáticas concluímos que o sucesso ou fracasso depende da forma como diferentes processos interagem entre si e que restrição é qualquer coisa que limite o sistema de atingir sua meta. Conforme GOLDRATT, (1990 e 1994) todo sistema deve ter pelo menos uma restrição ou fator limitante. Uma restrição não é boa nem má. Ela existe e deve ser gerenciada. A partir da premissa de que a empresa opera com algum tipo de restrição, Goldratt (1992,), formula um processo geral de tomada de decisão empresarial. O processo é conceituado pelo autor como, cinco passos de focalização e apresenta-se da seguinte maneira: 1 Identificar a(s) restrição(ões) do sistema; 2 Decidir como explorar a(s) restrição(ões) do sistema; 3 Subordinar qualquer outra coisa à decisão anterior; 4 Elevar a(s) restrição(ões) do sistema; 5 - Se nos passos anteriores uma restrição for quebrada, volte ao passo 1, mas não deixe que a inércia se torne uma restrição do sistema.

BAPTISTELLA, C.S.L.; FRANCISCO, V.L.F.S. Evolução do Mercado de Trabalho na Agropecuária Paulista, 1995-2004. IN: (XLIII CONGRESSO BRASILEIRO DE ECONOMIA E SOCIOLOGIA RURAL, Ribeirão Preto, SP, Anais. Brasília, SOBER, 2005.)

[5]. CSILLAG, João Mario; SAMPAIO, M. Gerenciamento de projetos segundo a teoria das restrições. . 3. ed. São Paulo: Anais, 2000. 133 p. 
[6]. CLARK, J. Estatística Aplicada . 1. ed. São Paulo: Saraiva, 1999. 351 p.

[7]. GIUNTINI, N. Teoria das restrições: uma nova forma de ver e pensar o gerenciamento empresarial . 1. ed. São Paulo: [s.n.], 2002. 380 p.

[8]. SALEMI, Luiz Felippe. ENTRESSAFRA, SAFRA OU SAFRINHA? . 1. 2009. Disponível em: <http://ENTRESSAFRA, SAFRA OU SAFRINHA?>. Acesso em: 10 abr. 2018.

[9]. https://revistagloborural.globo.com/Noticia s/Agricultura/Laranja/noticia/2017/12/globoruralsafra-brasileira-de-laranja-deve-diminuir-15-em201819-diz-usda.html

[10]. JUNIOR, Dirceu de Mattos et al. CITROS: principais informações e recomendações de cultivo . 1. 2005. Disponível em: <http://www.iac.sp.gov.br/imagem_informacoestec nologicas/43. pdf>. Acesso em: 17 abr. 2018.
[11]. CLIMA: SÃO PAULO: CLIMOGRAMA SÃO PAULO. 1. 2018. Disponível em: <https://pt.climatedata.org/location/655/ http://www.citrusbr.com/safras/2016>. Acesso em: 20 abr. 2018.

[12]. ROCHA, Keiler Carvalho. Commodities : 1O que é uma Commoditie?. 1. 2013. Disponível em: $<$ http://economiabr.net/economia/5_commodities.ht $\mathrm{ml}$. Acesso em: 01 abr. 2018.

[13]. COTAÇÕES de Laranja. 1. 2018. Disponível em: <https://www.noticiasagricolas.com.br/cotacoes/lar anja>. Acesso em: 08 abr. 2018.

[14]. http://www.apta.sp.gov.br/images_editor/n ovomapalaranjasp19082008.pdf) 


\section{Gapítulo 20}

\section{A REAL SITUAÇÃO DO TRANSPORTE DE CARGAS NO BRASIL}

\section{Luana Lima da Silva}

Nelson Henrique Moreira

\section{Patricia Carbonari Pantojo}

Resumo: Com a intenção de abrir uma discussão sobre o mercado de Transporte Rodoviário de Cargas no Brasil, este artigo faz uma apresentação e análise da evolução histórica do transporte de cargas, regulamentação do transporte no Brasil, os custos do transporte de cargas e quais são os fatores determinantes do valor do frete. Mostra ainda, uma avaliação do desempenho dos serviços de transporte de carga, assim como, o transporte de cargas em áreas urbanas. Essas informações ajudam a entender a real situação do transporte rodoviário de cargas no Brasil nos dias atuais, e assim buscar o que de melhor possa ser feito para melhorar no futuro. Este trabalho é uma pesquisa descritiva, utilizando-se de fontes bibliográficas e documentais, com o objetivo de mostrar a real situação do transporte de cargas no Brasil.

Palavras-chave: Transporte Rodoviário de Cargas; Custo do Transporte de Cargas; Fatores Determinantes do Valor do Frete 


\section{INTRODUÇÃO}

Com o desenvolvimento do Transporte Rodoviário de Cargas no Brasil, em 1980, foi promulgada a Lei no 6.813/80, que determinava, que a exploração do TRC deveria ser atividade privativa de transportadores autônomos brasileiros. Em seguida, em 1983, a Lei 7.092/83 criou o Registro Nacional de Transportes Rodoviários de Bens (RTB), que também fixava algumas condições para o exercício da atividade de TRC. A partir de então, para se ter a autorização legal para transporte, eram necessários a inscrição e o cadastro de todos aqueles que exerciam a atividade de transporte de bens (próprios ou de terceiros) com fins econômicos ou comerciais, por via pública ou rodovia, e as quotas eram limitadas à quantidade de registros anuais de transportadores.

Com a revogação da Lei 7.092/83, por não estar de acordo com Constituição Federal, ficou sem regras o acesso à atividade de transportador rodoviário de cargas no Brasil até 2001. Neste ano, a Lei 10.233/2001, criou a Agência Nacional de Transportes Terrestres (ANTT), e a regulação do mercado de TRC voltou a ser considerada.

A ANTT passou a exigir dos transportadores rodoviários de carga, em 2004, a inscrição no Registro Nacional de Transportadores Rodoviários de Cargas (RNTRC). Em 2009, esse registro deixou de ser apenas um cadastro e passou a ter a função de habilitação para o transportador rodoviário de cargas, através da publicação da Lei no 11.442/08 e da Resolução ANTT no 3056/09. Começou aí a regulação do mercado de TRC.

As análises dos dados do RNTRC são fundamentais para embasar a discussão acerca do mercado de Transporte Rodoviário de Cargas no Brasil. Assim, o objetivo deste trabalho é mostrar a real situação do transporte de cargas no Brasil, com a apresentação do panorama do mercado de transporte rodoviário de cargas a partir de dados relativos aos transportadores e seus veículos.

Para isso, através de uma pesquisa descritiva, utilizando-se de fontes bibliográficas e documentais, verificamos que, com exceção da região sudeste, há falta de infraestrutura nas rodovias de todo o país, o que acaba elevando o valor do frete. Ainda, como é regulamentado a atividade de transporte rodoviário de cargas.
Atualmente no Brasil, a publicação da Lei no 11.442/07 (BRASIL, 2007) e da Resolução ANTT no. 3056 (ANTT, 2009) trouxe à tona a discussão sobre a regulação do TRC. Contudo, essa não é uma discussão recente. Já houve outras tentativas, porém sem sucesso, de intervenção estatal neste setor.

\section{2 - EMBASAMENTO TEÓRICO}

A pesquisa se baseou primeiramente nas leis no 6.813/80 (determinou a exploração do Transporte Rodoviário de Cargas) e $n^{-}$ 7.092/83 (criou o Registro Nacional de Transportes Rodoviários de Bens (RTB).

Ainda, a lei 10.233/2001, criou a Agência Nacional de Transportes Terrestres (ANTT), mas a regulação do mercado de Transporte Rodoviário de Cargas só começou realmente com a lei $n^{\circ}$ 11.442/08 e a Resolução ANTT $n^{\circ}$ 3056/09.

O ILOS - Instituto de Logística e Supply Chain, no XVI Fórum Internacional de Logística, em 2010, apresentou uma pesquisa sobre os principais transportadores rodoviários do país, mostrando a situação do mercado em relação a diminuição de ofertas e aumento de preços.

Também, Maurício Lima, sócio-diretor da ILOS, mostrou que a relação de crescimento ou queda do modal rodoviário está relacionada diretamente proporcional ao PIB.

Estudos realizados pela Confederação Nacional do Transporte, demonstram as dificuldades estruturais no sistema rodoviário e como isso afeta a segurança da operação e o custo.

Caixeta-Filho et al (2009), explica que possibilidade do transporte de cargas de retorno para as zonas de origem pode diminuir o custo do frete, e que isso geralmente nas regiões mais desenvolvidas. O Banco Mundial, no seu ranking do desempenho logístico, mostrou que em 2014, o Brasil ficou à frente apenas da

Rússia entre os BRICS, na 65aㅗ posição.

\section{O TRANSPORTE DE CARGAS NO BRASIL}

Conforme o ILOS, mais de $60 \%$ do volume de mercadorias movimentadas no Brasil é de responsabilidade do transporte rodoviário de cargas. Para as empresas, o deslocamento de carga pelas estradas nacionais equivale a 
mais da metade da sua receita líquida, chegando a $62 \%$ da receita na Agroindústria e a $65.5 \%$ nas indústrias de alimentos. O ILOS - Instituto de Logística e Supply Chain, no XVI Fórum Internacional de Logística, em 2010, apresentou uma pesquisa inédita sobre 0 mercado brasileiro de transporte rodoviário de carga, e relatou:

Através do estudo com os principais transportadores rodoviários do país, pudemos analisar a situação do mercado, bem como suas restrições de oferta, a pressão para aumento dos preços e a sua busca pela melhoria de eficiência. (ILOS, 2010)

O transporte rodoviário é o preferido na movimentação interna de cargas no Brasil; essa preferência tem fundamentos logísticos, pois é possível chegar a quase que em qualquer lugar deste país pelas rodovias. No entanto, a ANTT afirma que existem diversos fatores que favorecem indevidamente a opção pelo transporte rodoviário no Brasil, como:

I - prática de excesso de carga, que acarreta na destruição da malha rodoviária nacional e em maiores custos de manutenção; II - falta de regulamentação da jornada de trabalho do motorista, permitindo que a viagem seja feita mais rapidamente e, consequentemente, reduzindo custos, ao mesmo tempo em que sacrifica o motorista e contribui para o aumento do número de acidentes de trânsito (cerca de 30\% dos acidentes de trânsito no país tem caminhões envolvidos); III sonegação de impostos, devido à ineficiência no controle da emissão de conhecimento de transporte ou mesmo da nota fiscal dos produtos transportados por autônomos; IV prática da carta-frete; e V -" prática de cobrança de fretes abaixo do custo, o que impede a renovação da frota (que tem idade média de 19 anos) e acarreta em consequências desastrosas para o consumo de combustível, poluição e acidentes. (ANTT, 2012)

ANTT (2008), citado por Wanke (2010), explica que o modal rodoviário leva vantagem sobre os outros modais pela sua flexibilidade em operar em qualquer via disponível, por não precisar grandes investimentos faz com que o transporte rodoviário seja muito atrativo para autônomos.A Confederação Nacional do Transporte, também afirma que existe uma série de dificuldades estruturais no sistema rodoviário: "o tráfego, por exemplo, se dá em rodovias em mal estado de conservação, o que compromete a segurança da operação e a torna mais onerosa" (CNT, 2010).

O ILOS (Instituto de Logística e Supply Chain), em seu estudo sobre Custos Logisticos no Brasil, afirma que:

O transporte rodoviário de cargas é, entre os modais, o que deve ter a recuperação mais lenta após a retomada dos números positivos da atividade econômica brasileira. Isso porque também foi o mais afetado pela queda do PIB (Produto Interno Bruto). Em 2015, o setor caiu 4,6\%. O PIB, por sua vez, teve uma retração de $3,1 \%$. Para o ano que vem, com a elevação da economia estimada em 1,3\%, o setor deve expandir 1,9\%.

Ainda, conforme Maurício Lima, sócio diretor da ILOS "o modal rodoviário está alavancado em relação ao PIB. Isso quer dizer que, se o PIB cresce, o transporte rodoviário aumenta mais; quando a economia decresce, o transporte rodoviário cai mais".

O sócio diretor da ILOS, afirma que quando a economia estava crescendo, os transportes ferroviário e aquaviário operavam no limite da capacidade, e isso fez com que aumentasse as cargas para o transporte rodoviário, mas quando a atividade econômica ficou negativa, foi o transporte rodoviário quem mais perdeu serviços, enquanto os outros modais continuaram com sua capacidade plena. Para Maurício Lima, o transporte rodoviário de cargas levará cerca de quatro anos para retornar ao patamar em que estava antes da crise econômica. Afirma que: "Apesar de a economia crescer em 2017, 2018 e 2019, ela não recupera o segmento. Só vai recuperar por volta de 2020. Essa é a notícia ruim. Mas a boa é que já passamos pelo pior momento, pelo momento de inflexão, e os números começarão a melhorar".Segundo Wanke (2010), o Brasil se encontra num forte movimento de modernização das empresas, melhorando cada vez mais seus serviços, garantindo confiabilidade e sistemas sofisticados. De outro, problemas estruturais na questão de priorizar investimentos governamentais levando o pais a uma dependência do modal rodoviário, tendo como resultado, baixos índices de produtividade, insegurança nas estradas e altos níveis de poluição ambiental. 
4 - OS CUSTOS DO TRANSPORTE DE CARGAS E OS FATORES DETERMINANTES DO VALOR DO FRETE

Para qualquer empresa, entender e conhecer os seus custos é importante para auxiliar na tomada de decisões e na formação do preço de seus produtos/serviços. Para as transportadoras isto não é diferente, pois conhecer os custos do transporte rodoviário de cargas, é necessário para a formação de preços de fretes que sejam adequados para pagar as despesas e obter um percentual de lucro desejado.Os principais custos no transporte de cargas, são: custo de coleta, entrega e transferência; custos Fixos; custos variáveis; despesas indiretas; custos relacionados com o valor; custos de gestão de riscos de acidentes e avarias (frete- valor); custos de gerenciamento de riscos de roubos (GRIS).Além desses custos, existem os custos que não estão relacionados com o volume ou o peso do bem transportado. Alguns destes custos podem ser: custo de permanência de carga (armazenagem); custo de cubagem; custo de devolução de mercadorias; reentrega, segunda e terceira entregas; custo de estadia do veículo; custo de administração das secretarias da fazenda; custo de dificuldade de entrega; custos de restrição ao trânsito.Para Caixeta-Filho et al (2009), “ ... o frete para um destino onde haverá congestionamento, o que implica demora na descarga, é mais caro que para outro destino, com igual quilometragem e condições de vias, onde 0 processo será mais ágil"Conhecer os principais custos do transporte rodoviário de cargas é fundamental para que a empresa possa administrar seu capital, realizar cobranças adequadas e competir em seu mercado com eficiência. Portanto, vale a pena estar sempre atento a este assunto e acompanhar de perto os custos, já que alguns deles estão sempre sendo reajustados.

Caixeta-Filho et al (2009), explica que o transporte de cargas com destino aos portos e as regiões mais desenvolvidas, como os Estados do Sudeste e Sul do Brasil, pode representar fretes menores devido à possibilidade do transporte de cargas de retorno para suas zonas de origem.

Segundo a Consultoria ILOS, entre 2010 e 2012, os gastos do Brasil com transporte pelo modal rodoviário subiram de $R \$ 202,6$ bilhões para $\mathrm{R} \$ 275,6$ bilhões. Essa diferença substancial se deve ao crescimento de $14 \%$ da demanda por transporte rodoviário nesses dois anos, em decorrência da falta de opções de outros modais, e do aumento de $20 \%$ no preço do frete no período, levando a um aumento total de $36 \%$ no custo do transporte rodoviário no País (Figura 1).

Figura 1 - Comparação do custo do modal rodoviário de carga e o volume transportado entre 2010 e 2012

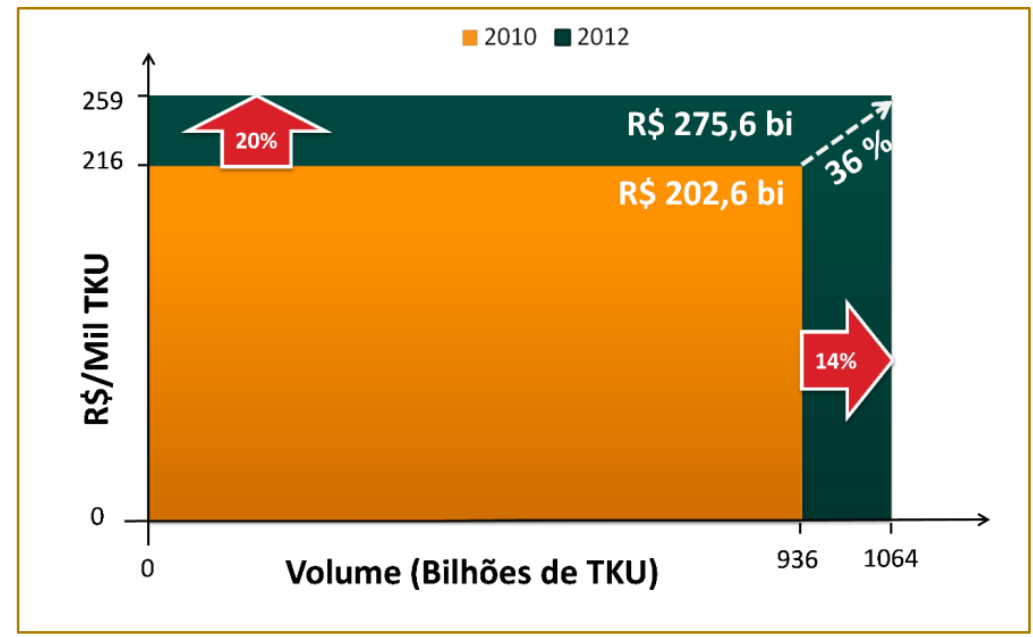

Fonte: ILOS

A Consultoria ILOS, relata:

A análise dos custos logísticos no Brasil nos últimos dez anos deixa claro esse impacto do modal rodoviário. Até 2010, o custo logístico do País em relação ao PIB vinha sofrendo sucessivas quedas, interrompidas em 2012 pela falta de infraestrutura, levando a um retrocesso de 6 anos em termos de custos logísticos. Assim, enquanto o Brasil voltou a ter custos logísticos de 11,5\% do PIB (Figura 
Figura 2 - Custos logísticos comparado com o PIB.

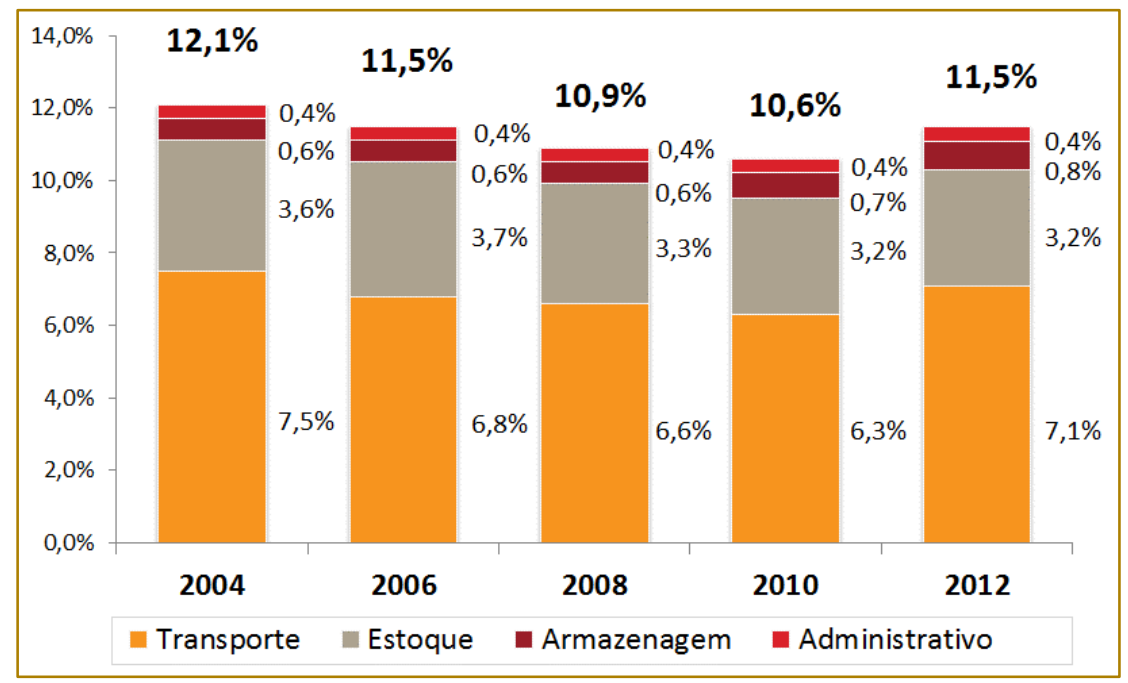

Fonte: ILOS

\section{DESEMPENHO DOS SERVIÇOS DE TRANSPORTE DE CARGAS}

A carência na infraestrutura de transportes tem um impacto significativo para o Brasil em rankings como o de desempenho logístico.

O Banco Mundial, desde 2007, divulga de dois em dois anos, o ranking do desempenho logístico. Na edição de 2014, o Brasil ficou na
65ํㅗㄹ posição, a frente apenas da Rússia entre os BRICS. Para o ranking, o Banco Mundial analisa seis itens (Consistência/ Confiabilidade, Rastreamento de Carga, Competência dos Serviços, Disponibilidade de Transporte, Procedimento de Alfândega e Infraestrutura), com o Brasil tendo ficado na 54aㅡ posição no item Infraestrutura, novamente à frente apenas da Rússia (Figura 3).

Figura 3 - Ranking do Índice de Desempenho Logístico do Banco Mundial - 2007 a 2014

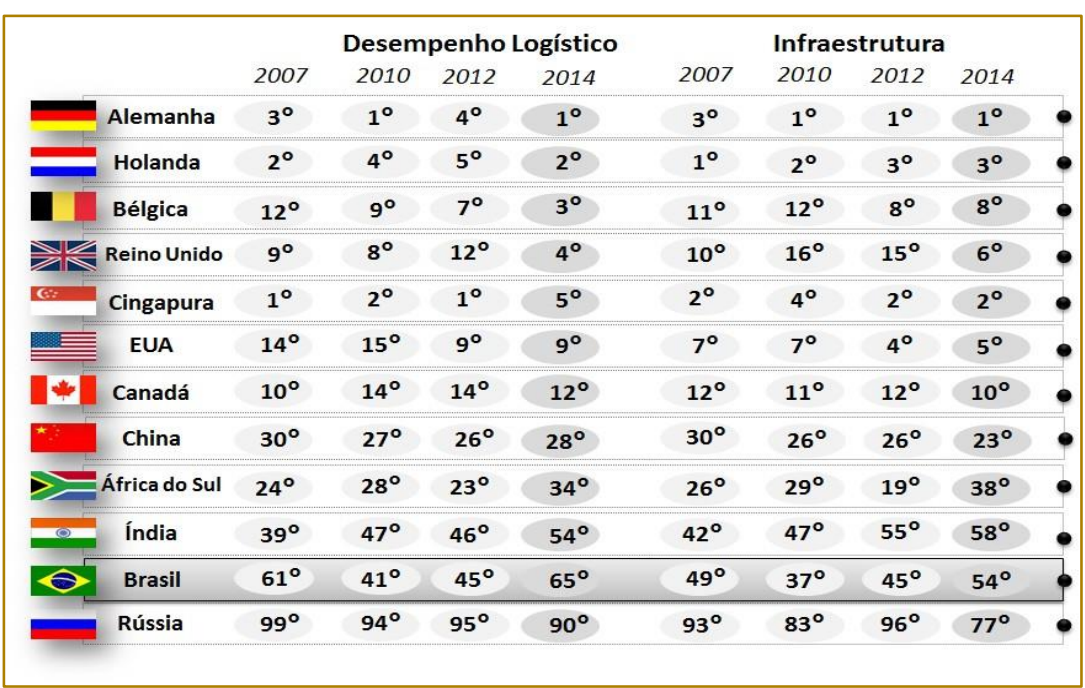

Fonte: Banco Mundial 


\section{CONSIDERAÇÕES FINAIS}

A limitação de infraestrutura deve continuar ainda por um bom período, e isso vai fazer com que continue em alta a utilização de todos os modais, podendo, até mesmo, aumentar um pouco a participação do modal rodoviário na matriz de transportes.

No entanto, o modal rodoviário levará alguns anos para voltar a ser como era antes, o crescimento deve acompanhar o crescimento econômico do país.

Quando comparado com 2013, os anos de 2014 e 2015, teve um pequeno, mas importante crescimento, mesmo porque a economia do país também estava estagnada

Com relação aos gastos com logística no Brasil em um futuro próximo, é quase certo que este acompanhe a inflação. De qualquer forma, é importante que o governo se preocupe em investir em infraestrutura de

\section{REFERÊNCIAS}

[1]. VALENTE, Amir Mattar; NOVAES, Antônio Galvão; VIEIRA, Gerenciamento de transporte e frotas, Eunice Passaglia. CENGAGE Learning, São Paulo, 2008.

[2]. CAIXETO-FILHO, José Vicente; MARTINS, Ricardo Silveira. Gestão Logística do transporte de cargas, 1aㅡ edição, Atlas, São Paulo, 2009.

[3]. VALENTE, Amir Mattar; VIEIRA, Eunice Passaglia; outros. Qualidade e produtividade nos transportes, CENGAGE Learning, São Paulo, 2008.

[4]. CUSTOS LOGISTICOS NO BRASIL
Disponível em:

<http://www.ilos.com.br/web/custos-logisticos-nobrasil/> Acesso em 08 de abril de 2017. transporte para melhorar a disponibilidade de modais e permitir que as empresas alcancem maior eficiência, evitando pressão de custos, mesmo que seja em um futuro distante.

É papel do governo prover infraestrutura necessária para garantir a oferta de transportes em todos os modais, permitindo a sustentabilidade do crescimento econômico sem impacto nos custos logísticos das empresas.

A infraestrutura de transportes tem uma variedade de benefícios sobre a sociedade, tais como aqueles referentes à disponibilidade de bens, à extensão dos mercados, à concorrência, aos custos das mercadorias, entre outros.

O investimento em transporte é estratégico para uma política de desenvolvimento econômico; principalmente nas regiões em desenvolvimento os investimentos contínuos em transporte podem ter grande influência.

\section{[5]. CUSTOS DO TRANSPORTE RODOVIÁRIO DE CARGAS Disponível em:} <http://blog.hivecloud.com.br/2015/10/custos-dotransporte- rodoviario-cargas.html> Acesso em 08 de abril de 2017.

$\begin{array}{lrr}\text { [6]. FATORES DETERMINANTES DO VALOR } \\ \text { DO } & \text { FRETE } & \text { Disponível }\end{array}$ <https://wmsalogistica.wordpress.com/2012/11/14/f atores- determinantes-do-valor-do-frete/> Acesso em 08 de abril de 2017.

[7]. CRISE AFETA SETOR DE TRANSPORTE, MAS HÁ OTIMISMO MODERADO PARA 2017 Disponível em: <http://www.cnt.org.br/Imprensa/noticia/crise-afetasetor-de- transporte-mas-ha-otimismo-moderadopara-2017> Acesso em 08 de abril de 2017. 


$$
\text { Alutary }
$$




\section{Acyr Elias Freire Junior}

Bacharel em ciências econômicas pela UCAM-RJ (Universidade Cândido Mendes), curso de Open Market pela Fundação Getúlio Vargas-RJ, MBA em Mercados Derivativos e Futuros pela UCAM-RJ, Curso Bolsa de Valores e o Mercado acionário pela BVRJ; Curso de formação de operadores pela Bolsa de Mercadorias e Futuros ( BM\&F-RJ), Mestrado em Eng ${ }^{a}$. de Produção e Sistemas pela UFSC - Universidade Federal de Santa Catarina.

\section{Aline Yuri Muranaka Yajima}

Graduanda em Logística pela Faculdade de Tecnologia de Mauá - FATEC Mauá. Técnico em Informática pelo Centro Educacional ETIP. Fez parte do Núcleo de Pesquisa na FATEC Mauá. Exerceu estágio na área de gestão estratégica em uma empresa de engenharia de tráfego, desenvolvendo e gerando de relatórios para análise dos resultados e indicadores de gestão. Atuou na área de Planejamento e Controle da Produção como programadora de produção, no ramo de peças automotivas. Atualmente atua na área de transporte, auxiliando nos faturamentos do setor, em uma empresa especializada em desembaraço e agenciamento de cargas.

\section{Amanda Domingues}

Discente do curso de Tecnologia em Logística da Faculdade de Tecnologia de Mogi das Cruzes, São Paulo. Participou do congresso FatecLOG 2018 em Santos.

\section{Antonio César Gallhardi}

Graduado em Engenharia de Materiais pela Universidade Federal de São Carlos (1981), Mestre em Ciência e Engenharia dos Materiais pela Universidade Federal de São Carlos (1985) e Doutor em Engenharia Mecânica pela Universidade Estadual de Campinas (1998). Pós Doutorado em Administração pela Florida Christian University - USA, Estágio Pós Doutoral pela Escola Politécnica - USP em Engenharia de Produção Mecânica (2013). Atualmente é professor pleno da Faculdade de Tecnologia de Jundiaí, professor permanente do Mestrado Profissional em Gestão e Tecnologia em Sistemas Produtivos - Centro Estadual de Educação Tecnológica Paula Souza, e responsável pelas disciplinas: Inovação e Competitividade Sistêmica; Otimização de Sistemas Produtivos. Possui 25 anos de experiência em gerenciamento de sistemas de manufaturas. Possui 18 anos de experiência acadêmica como professor universitário e 6 anos de experiência em gestão acadêmica: coordenador de curso (graduação, lato senso, stricto senso); diretor de faculdade. Experiência profissional no exterior. Tem experiência na área de Tecnologia da Informação, Administração da Produção e Logística. Gestor do Grupo de Pesquisa no CNPQ: Gestão de Operações e Logística, atuando em Projeto de Pesquisa Inteligentes e Sustentáveis; principalmente nos seguintes temas: Estratégias Competitivas, Inovação Tecnológica; Pesquisa Operacional e Simulação, Simulação Social, Layout Sistemas Médicos Hospitalares, Gestão da Manutenção de Equipamentos Médicos Hospitalares; Gestão de Operações e Logística, Logística Humanitária; Ciclo de Gestão de Catástrofes; Manufatura Virtual, Equipes Virtuais e Teletrabalho; Design Science; Computação Embarcada Automotiva..

\section{Átila de Arruda Brito}

Possui graduação em Informática com ênfase em Gestão de Negócios pela Faculdade de Tecnologia de Itaquaquecetuba (2010), especialização em Docência no Ensino Superior pela Faculdade Aldeia de Carapicuiba (2011) e especialização em Gestão de Projetos pela Universidade Braz Cubas (2012). Tem experiência na área de Ciência da Computação, com ênfase em Metodologia e Técnicas da Computação. 


\section{Barbara Soares da Silva}

Undertaking PhD in Applied Linguistics; Corpus Linguistics at PUCSP. Sumaré Institute Professor at Bilingual Executive Secretary Course. FATECSP English Teacher - Higher Education in Both Courses. Consecutive Interpreter in French, English and Spanish Language. Masters/Mestrado - São Paulo Catholic University - Brazil in Applied Linguistics (PUCSP). Future: Doctorate Project enabled to be submitted to São Paulo Catholic University (2013). Expertise: Corpus Linguistics/Statistics (English Language \& Information Technology). Subject: Change Management (ITIL)

\section{Caio Fabio Ferraz Santos}

Aluno do CST em Logística da Fatec Mogi das Cruzes

\section{Célia De Lima Pizolato}

Doutoranda em Epistemologia e História da Ciência na Argentina - Buenos Aires - UNTREF/ 2015 Mestrado em Controladoria e Contabilidade Estratégica ata de defesa aprovada 2003, área de concentração o Ensino da Contabilidade pelo Centro Universitário Alvares Penteado UNIFECAP. Especialização em Didática do Ensino Superior pela Universidade Mackenzie. Especialização em Controladoria pela Universidade Mackenzie. Especialização gestão Financeira e Contabilidade Avançada pela Universidade São Judas. Didática do ensino Técnico Esquema I pela Faculdade Campos Salles. Graduação em Ciências Contábeis pelo Centro Universitário das Faculdades Metropolitanas Unidas. Área de conhecimento e atuação Contabilidade como fonte de informações Logísticas. Instituições, Contribuições Acadêmicas Coordenação e Administrativas: Ensino Técnico desde 1977. Ensino Superior desde 1987 nos cursos: Tecnológicos, Graduação e Pós-graduação.

\section{Cibelle William Costa}

Cursando Logística pela Faculdade de Tecnologia Baixada Santista - Rubens Lara, com previsão de término para o primeiro semestre de 2020. Domínio básico do idioma inglês. Participação de palestras ministradas na faculdade, com profissionais atuantes no mercado de trabalho da área de logística. Conhecimento básico no Pacote Office e perfil de profissional empenhado, comprometido, com facilidade para trabalhar em equipe e de rápida adaptação. Em busca de crescimento profissional.

\section{Claudio Tadeu Pinheiro De Oliveira}

Aluno do Mestrado Profissional em Gestão e Tecnologia em Sistemas Produtivos pela PósGraduação do Centro Paula Souza - Turma 5/2017; graduação em Administração pela Escola Superior de Administração de Negócios (1999) e Pós Graduação em Administração pelo Centro Universitário das Faculdades Metropolitanas Unidas (2003). Lecionou na Universidade Nove de Julho (Uninove) á partir do 1 semestre de 2004 até 1 semestre de 2015 na Graduação de Administração e cursos de Tecnologia (Comércio Exterior, Logística, Qualidade, Processos Gerenciais, Gestão Comercial, Marketing). Atuei na graduação e tecnologia nos módulos presencial e EAD, com experiência na área de Administração, atuando com ênfase na disciplinas: Teoria geral da Administração; Sistemas de Informação; Organização, Sistemas e Métodos; Processos Organizacionais; Gestão Ambiental; Recursos Humanos. Foi integrante do Grupo de Pesquisas em Gestão de Pessoas, pela Diretoria de Gerenciais da UNINOVE, junto ao CNPQ até o 1 semestre de 2015.

\section{Cristovão Rocha Sousa}

Possui graduação em Tecnologia pela Faculdade de Tecnologia em Logística do Centro Paula Souza (2018), FATEC, campus Zona Leste. Tem experiência como Analista de 
Distribuição da Schincariol Logística, uma companhia do segmento de bebidas que atualmente pertence a um Grupo Holandês.

\section{Daiane Belchior}

Cursando Mestrado Profissional em Gestão e Tecnologia em Sistemas Produtivos pelo Centro Paula Souza (2017/2019). Possui pós-graduação em Gestão de Projetos e Processos Organizacionais pelo Centro Paula Souza (2015/2017) e graduação em Engenharia de Produção pelo Centro Universitário Anhanguera (2013) e graduação em Tecnologia em Produção - Ênfase em Plásticos - Fatec Zona Leste (2009). Atualmente é Consultora na área de Gerenciamento de Projetos.

\section{Denílson Luiz de Carvalho}

Mestre em Gestão e Tecnologia em Sistemas Produtivos pelo CEETEPS (Centro Paula Souza). Duas espacializações complementares na Fundação Getúlio Vargas (FGV) em Administração e MBA em Gestão Empresarial com Ênfase em Supply Chain. Pós-Graduação em Metodologias Ativas (Faculdade Don Domênico). Duas formações sinérgicas: Tecnologia em Logística de Transportes pela FATEC e Tecnologia em Comércio Exterior pela UMAUNIMONTE.

\section{Edi Carlos Da Silva Santos}

Formado em Administração pelo Instituto Municipal de Ensino Superior de Bebedouro (IMESB) em 2016, atuou como Analista de Logística durante 12 anos na empresa Coopercitrus de Bebedouro, é autor de vários artigos na área de administração e logística. Atualmente trabalha como gerente de logística na empresa Bebedouro Caçambas e é aluno do quarto semestre do curso de Tecnologia em Logística da FATEC de Bebedouro.

\section{Edna Veloso De Medeiros}

Bacharel em Administração de Empresas e Comércio Exterior. Mestrado em Gestão Ambiental. Curso de Pós Graduação em Administração e Comércio Exterior. Pós em Gestão de Educação à Distância. Pós em Neurociências e Metodologias Ativas. Professora do ensino superior desde o ano de 2011 na Fatec nos cursos de Gestão Empresarial, Logística, Gestão Portuária e Análise de Sistemas e desde 2004 nos Cursos Técnicos de Administração, Logística e Segurança do Trabalho.

\section{Edney Eboli dos Santos}

Desenhista Industrial com Habilitação em Projeto do Produto graduado pela Universidade São Judas Tadeu (1996). Especialista em Artes plásticas (Universidade São Judas Tadeu (1998). Especialista Master em Gerenciamento de Projetos pela George Washington University (2007). Mestrando do programa de Mestrado Profissional "Gestão e Tecnologia em Sistemas Produtivos" do Centro Estadual de Educação Tecnológica Paula Souza. Professor Adjunto do Centro Universitário FMU / FIAM-FAAM e Designer de produto (Color\&Trim) na Volkswagen do Brasil. Atua na área de Design automobilístico desde 1992, com experiência desde as fases iniciais de projeto até a definição final do produto (conceituação do produto, modelamento em clay, técnicas e processos de modelagem, engenharia reversa, registro técnico do produto, pesquisa e desenvolvimento do produto, viabilidade técnica do produto, materiais e processos industriais, Gerenciamento de Projetos com foco em Gestão do Design, texturização de moldes de injeção para peças plásticas e renderização digital). 


\section{Elci De Sales Mota Oliveira}

Técnica em Contabilidade ETEC Caraguatatuba (Escola Técnica Centro Paula Souza) Tecnóloga em Gestão Empresarial FATEC São Sebastião (Faculdade Técnica Centro Paula Souza)

\section{Eliacy Cavalcanti Lélis}

Administradora e engenheira, especialista em educação superior, mestre e doutora em engenharia de produção, pós-doutoranda em tecnologias de inteligência e design digital. Tem experiência profissional administrativa e técnica na área logística, na manufatura e em serviços no setor público e privado. Na área acadêmica, é pesquisadora, professora, conteudista e tutora na graduação e pós-graduação, no ensino presencial e na educação a distância, nas áreas de administração e engenharia. Parecerista de revistas e eventos. Associada do PMI e da ABEPRO. Voluntária da entidade Transporte Ativo. Publicou diversos livros, capítulos de livro e artigos. Leciona nas áreas de gestão da qualidade, gestão ambiental, responsabilidade social, gestão de projetos, gestão de operações, logística, gestão da cadeia de suprimentos, estratégia, sistema de informação, segurança e saúde do trabalho, avaliação institucional e mobilidade urbana.

\section{Enio Fernandes Rodrigues}

Doutor em Engenharia de Produção, Mestre em Engenharia de Produção, com graduação em Administração de Empresas. Atualmente é Professor do Instituto Federal de Educação, Ciência e Tecnologia de Suzano (IFSP) , atuando nos cursos de Graduação e Pós-Graduação em Logística. Foi professor da Faculdade de Tecnologia de Guarulhos (FATECGUARULHOS), Faculdade de Tecnologia de Itaquaquecetuba (FATEC ITAQUÁ), da PósGraduação da Faculdade de Tecnologia de São Paulo (FATEC-SP).

\section{Fernando Julio Martines}

Motorista de transporte urbano

\section{Gabriel José Barbosa}

Engenheiro de Computação, pós-graduado em Gestão de Projetos (Instituto Federal de Educação, Ciência e Tecnologia São Paulo - IFSP). Atualmente é chefe de Tecnologia da Informação - Polícia Civil do Estado de São Paulo e Professor da Academia de Polícia Civil de São Paulo. Tem experiência na área de Engenharia Elétrica, com ênfase em Engenharia da Computação, atuando principalmente nos seguintes temas: forense, computação, segurança, informação, gestão, treinamentos. Leciona disciplinas na área de Tecnologia da Informação, principalmente em Segurança da Informação, Computação Forense, Hardware, Arquitetura de Computadores, Redes, Sistemas Operacionais.

\section{Geisy Anny Venâncio}

Natural de Manaus-AM, professora efetiva do Instituto Federal de Educação, Ciência e Tecnologia do Amazonas. Mestre em Design pelo Programa de Pós-Graduação em Design da Universidade Federal do Paraná . Especialista em: Design Instrucional para EaD Virtual pela Universidade Federal de Itajubá Educação a Distância, com habilitação em Tecnologias Educacionais, pelo Instituto Federal de Educação, Ciência e Tecnologia do Paraná; e em Planejamento, Implementação e Gestão da EaD, pela Universidade Federal Fluminense . Bacharel em Desenho Industrial com habilitação em Projeto do Produto, pela Universidade Federal do Amazonas. Em Cooperação Técnica com o Instituto Federal de Educação, Ciência e Tecnologia de Minas Gerais, Campus Santa Luzia desde junho/2018. 


\section{Heberty Da Silva}

Graduado em Administração de Empresas \& Marketing. Graduado em Gestão Comercial Fatec SP. Experiência na área de bebidas e alimentos (Heineken, Mars, Natural One, Ovomaltine). Coordenador de projetos e contas (Banco Itau) Especialista na área de vendas e novos negócios.

\section{Henrique Menezes Nogueira}

Graduando em Tecnologia em Logística pelo Instituto Federal de Educação, Ciência e Tecnologia do Amazonas - IFAM, Campus Manaus Distrito Industrial. Técnico em Eletrotécnica também pelo Instituto Federal de Educação, Ciência e Tecnologia do Amazonas, Campus Manaus Centro. Linhas de pesquisa: Logística empresarial e Logística Reversa

\section{João Pedro Garcia De Souza}

Graduanda em Tecnologia em Logística pelo Instituto Federal de Educação, Ciência e Tecnologia do Amazonas - IFAM, Campus Manaus Distrito Industrial. Linhas de pesquisa: Logística empresarial.

\section{Jose Carlos Redaelli}

Possui graduação em Ciência da Computação pela Universidade Estadual de Campinas (1977) e Mestrado em Engenharia Civil (2016) com a dissertação; Avaliação de Diferentes Estratégias de Aprendizagem entre Alunos da Graduação, Pós-Graduação e Especialização da Engenharia Civil-Área de Transportes: Aprendizagem Autorregulada. Apresentação Oral no IGIP-41st International Conference on Engineering Pedagogy, 2012 (Villach/Austria). "SelfRegulated Learning Strategies Applied to Undergraduate, Graduate and Specialization Students from Civil Engineering". - Apresentação Oral no "IGIP-2011-International Society for Ingeneering Education", 2011 (Santos/SP Brasil).

\section{Juliana Ferreira de Vales}

Possui graduação em Logística com ênfase em Transportes pela Faculdade de Tecnologia da Zona Leste FATEC (2007), e Licenciada em Pedagogia (2010), possui pós-graduada em Engenharia de Produção (2015). Atualmente é professora do Centro Estadual de Educação Tecnológica Paula Souza e Universidade Brasil como professora de Logística e Administração. Atuação durante 7 anos em Industria Plástica na área de Logística e desde de 2011 atuando na área de Educação, em andamento como aluna especial no curso de Mestrado em Engenharia Civil área de atuação Transportes pela UNICAMP.

\section{Julio Cesar Ferreira Dos Passos}

Foi Mediador Pedagógico da área de Engenharia de Produção da Universidade Virtual do Estado de São Paulo (UNIVESP). Atuou como profissional nas áreas de Supply Chain e Engenharia de Produção exercendo atividades de análise da cadeia de suprimentos e processos produtivos, envolvendo rentabilidade das operações, projetos sistemas logísticos e transportes, analise custos e processos industriais (Votorantim e DHL).Obteve a Especialização em Engenharia de Produção (2015) na PUC Minas, Aperfeiçoamento em Educação a Distância e Metodologias Ativas (ABP) em (2016) e atualmente é aluno de Mestrado (2017) em Engenharia de Transportes pela Universidade Estadual de Campinas (UNICAMP). 


\section{Junior Lemes}

Analista Logístico

\section{Larissa Donato Leite}

Cursando Tecnólogo em Logística - Fatec Rubens Lara - Baixada Santista. Habilidades para trabalhos em equipes. Qualidades: eficiente, prestativa, comunicativa e responsável e principalmente aberta para novos desafios.

\section{Leandro De Souza Santos}

Aluno do curso superior de tecnologia em logística na Faculdade de Tecnologia de Mogi das cruzes, trabalho na área de faturamento e expedição há nove anos na empresa Aunde do Brasil.

\section{Leticia Perez da Silva \\ Graduada Gestão Comercial - Fatec SP}

\section{Luana Lima Da Silva}

Técnico em Logística e estudante em Gestão Portuária Fatec - São Sebastião - SP

\section{Lucas Santos da Costa}

Pós-graduado em logística e operações pelo Instituto Federal de Educação, Ciência e Tecnologia de Suzano (IFSP), com Graduação Tecnológica em Logística pela Faculdade de Tecnologia de Guarulhos (FATEC). Tem experiência na área de Suprimentos em empresa de logística e distribuição.

\section{Lucas Mateus De Araújo}

Graduado em Tecnólogo de Logística na Unidade Fatec Rubens Lara - Baixada Santista. Habilidades para trabalhos em equipes. Qualidades: responsável, criativo e apto para novas conquistas e realização de objetivos pessoais e profissionais.

\section{Luciana Vasques Sanches Cardoso}

Possui graduação em Tecnologia em Logística pela Faculdade de Tecnologia de Sorocaba (2017), graduação em Pedagogia pela Universidade de Sorocaba (2007) e pós-graduação em Educação Empreendedora pela Universidade Federal São João Del Rei (2016). Atualmente é professora da Rede Municipal de Sorocaba.

\section{Luciano da Silva Ferreira}

Professor universitário em cursos de graduação nas áreas de Administração de Empresas e Logística. Estudante de Mestrado Profissional em gestão e tecnologias em Sistemas Produtivos, na unidade de pós-graduação, extensão e pesquisa do Centro Estadual de Educação Tecnológica Paula Souza. Pós-graduado em Logística Empresarial pela Universidade Presbiteriana Mackenzie. Formado em Administração de Empresas pela Universidade Guarulhos. Tem experiência de mais de 20 anos em Logística, tanto no serviço público como em empresas privadas e leciona a mais de 10 anos em cursos técnicos e tecnológicos nas áreas de Logística e Administração de empresas. 


\section{Marcos Antônio Luciano}

Supervisor de transportes

\section{Marilia De Souza Santos}

Cursando Tecnólogo em Logística na Fatec-Mauá, tenho 26 anos, possuo ampla experiência na área de tecnologia da informação onde atuo até a presente data como técnica residente no TJSP.

\section{Marilia Macorin de Azevedo}

Doutora em Engenharia pela POLI - Universidade de São Paulo (USP). Mestre em Qualidade pela Universidade de Campinas (UNICAMP). Graduada em Tecnologia de Processamento de Dados pela Faculdade de Tecnologia de São Paulo (FATEC SP). Foi vice-diretora, diretoria acadêmica das Faculdades e CET Radial e Reitora de seu sucedâneo, o Centro Universitário Radial. Realiza pesquisas na área de Gestão da Qualidade, Engenharia e Ciência de Serviços, Gestão Estratégica da TI, Gestão e Avaliação da Educação Profissional e uso das Tecnologias na Educação. Atualmente é professora Pleno da Faculdade de Tecnologia de São Paulo, professora permanente do Mestrado Profissional em Gestão e Tecnologia em Sistemas Produtivos e do Mestrado Profissional em Gestão e Desenvolvimento da Educação Profissional - ambos do Centro Estadual de Educação Tecnológica Paula Souza, participando das disciplinas: Inovação e Competitividade Sistêmica; Gestão Estratégica de TI, Gestão da Qualidade, Gestão de Sistemas e Avaliação da Educação Profissional, entre outras. Possui 30 anos de experiência acadêmica como professora universitária além de experiência com desenvolvimento de sistemas e gestora na área de TI.

\section{Marina Codo Andrade Teixeira}

Doutora em Educação: Currículo pela Pontifícia Universidade Católica de São Paulo (2015), possui Mestrado em Administração de Empresas pela Fundação Getúlio Vargas (2010), MBA Executivo em Gestão Estratégica de Pessoas pela Fundação Getúlio Vargas (2006) e Graduação em Administração pela Pontifícia Universidade Católica de Campinas (2004). Atualmente é professora da Fatec Mogi das Cruzes nos Cursos Superiores de Tecnologia em Recursos Humanos e Logística e responsável pela disciplina Gestão de Pessoas do curso de Gestão empresarial do Centro Paula Souza

\section{Nataly Da Silva Moraes}

Estudante de Logística na Fatec Mauá, Técnica em Logística pela Etec Lauro Gomes. Possuo experiência na área de Transportes e atualmente trabalho no ramo de Logística Reversa.

\section{Nelson Henrique Moreira}

Técnico em contabilidade e estudante de Gestão Portuária na Faculdade de Tecnologia do Estado de São Paulo em São Sebastião - SP.

\section{Orlando Fontes Lima Junior}

Professor Titular do Departamento de Geotecnia e Transportes da Faculdade de Engenharia Civil, Arquitetura e Urbanismo (FEC) da UNICAMP. Obteve a Livre Docência (2004) na UNICAMP, O Doutorado (1995) e Mestrado (1988) em Engenharia de Transportes pela Universidade de São Paulo. Na Graduação (1982) concluiu Engenharia Naval pela Universidade de São Paulo. Realizou Pós-Doutorado na Universidade Estadual de Campinas (2006) e na Bournemouth University (2007). Foi Professor da Escola Politécnica da Universidade de São Paulo (1990 a 1996). Atualmente é vice coordenador de Extensão e 
Eventos da FEC/UNICAMP e coordena o Laboratório de Aprendizagem em Logística e Transportes (LALT).

\section{Patricia Carbonari Pantojo}

Possui MBA em Administração Financeira, Contábil e Controladoria pela Universidade Livre de São Paulo, (2017).Especialização em Docência do Ensino Superior pela Universidade Livre de São Paulo (2015), Licenciatura Plena - Resolução 2 pelo Centro Universitário de Araras Dr. Edmundo Ulson (2012), Bacharel em Administração de Empresas com ênfase em Comércio Exterior pela Universidade Bandeirante de São Paulo (1995). Atualmente é professor de nível técnico na Etec São Sebastião e Etec de Caraguatatuba, e professora de ensino superior na Fatec de São Sebastião.

\section{Paulo Cesar Giuliani}

Possui graduação em Engenharia pela Fundação Educacional Inaciana Padre Saboia de Medeiros - FEl (1983) e mestrado em Administração pela Pontifícia Universidade Católica de São Paulo (1997). Atualmente é professor nas seguintes instituições: Promoção do Ensino de Qualidade (FACAMP), Fundação Escola de Comércio Álvares Penteado (FECAP) e Faculdade de Tecnologia do Estado de São Paulo (FATEC Mogi das Cruzes). Tem lecionado nos cursos de engenharia da produção, administração, tecnologia em logística e no agronegócio. Tem experiência na área de Administração, com ênfase em Gestão de Operações, Materiais e Logística.

\section{Paulo Douglas Cavalcante Da Silva}

É graduado do Curso Superior de Tecnologia em Logística e graduando do Curso Superior de Tecnologia em Comércio Exterior da Faculdade de Tecnologia da Zona Leste de São Paulo (FATEC ZL). Atua profissionalmente desde 2002 com importação e exportação, prestando serviços para Copa Airlines e Sky Airlines. Teve ampla experiência profissional com transporte aéreo como analista de tracking e agente de carga.

\section{Peterson Rony Vicente de Matos}

Graduando do curso de Logística, pela Faculdade de Tecnologia do Centro Paula Souza, FATEC. No âmbito profissional é Gerente de Prevenção de Perdas do Grupo Carrefour, companhia líder do segmento que atua no mercado varejista nacional, ele atua profissionalmente no segmento de varejo e atacado em redes de hipermercados e supermercados. Sua especialidade é Gestão de Equipes, Gestão de Estoques, Auditoria aos Inventários, Análise e Tratamento de Dados, bem como Análise e Desenvolvimento de Processos.

\section{Ralph Felipe Alves Benites}

Discente do curso de Tecnologia em Logística da Faculdade de Tecnologia de Mogi das Cruzes, São Paulo. Participou do congresso FatecLOG 2018 em Santos.

\section{Renata dos Santos Andrade}

Graduada Gestão Comercial - Fatec SP

\section{Rhadler Herculani}

Engenheiro de Produção Agroindustrial formado pela Universidade Federal de São Carlos (UFSCar), mestrado na área de Organização do Trabalho/ Projeto do Trabalho e Ergonomia (UFSCar). Coordenador do Curso de Engenharia de Produção do Centro Universitário 
UNIFAFIBE. Professor da FATEC de Bebedouro. Orientador de vários temas de Iniciação Científica. Tem experiência em projetos envolvendo a área de Educação: Projetos de Pesquisa, Projetos de novos cursos universitários, Pesquisa Científica e Projetos Pedagógicos, além de atuar nas áreas de Ergonomia, Simulação, Planejamento, Processos de Produção e Projetos de Fábrica.

\section{Roberto Giusti}

Engenheiro especialista em logística com cerca de 30 anos de experiência profissional e cerca de 20 anos como acadêmico. Atualmente professor titular em disciplinas do curso de logística na Fatec de Mauá.

\section{Roberto Kanaane}

Graduado em Psicologia pela Universidade Mogi das Cruzes (1974), Mestrado em Psicologia Social pela Universidade de São Paulo (1984) e Doutorado em Ciências pela Universidade de São Paulo (1989). Professor de Ensino Superior Concursado junto a Fatec SP - Faculdade de Tecnologia. Professor dos Programas de Mestrado Profissional do Centro Estadual de Educação Tecnológica Paula Souza: Gestão e Tecnologia em Sistemas Produtivos; Gestão e Desenvolvimento da Educação Profissional. Pesquisador junto ao CNPq no grupo de pesquisa em gestão de operações e logística (Sistemas Produtivos); pesquisador junto ao CNPq no grupo gestão e avaliação (Educação); pesquisador junto ao CNPq no grupo de pesquisa práticas da educação profissional e tecnológica e educação corporativa. Professor do Programa Pós- Graduação Lato Sensu do Centro Estadual de Educação Tecnológica Paula Souza. Coordenador de Pós-Graduação Lato Sensu em Gestão Pública; Gestão Ambiental e Meio Ambiente; Pós em Sistemas de Gestão Integrada (SGI) e Pós em Gestão Estratégica de Pessoas nas Organizações Públicas. Experiência na área de Administração, com ênfase em Gestão de Pessoas, atuando principalmente em: Gestão do Conhecimento; Processos Socioprofissionais; Comportamento Ético em Hospitalidade. Sócio-Diretor da Roka Consultoria em Gestão de Pessoas. Experiência acentuada na área de Educação tanto em nível acadêmico como em nível de gestão, desenvolvendo atividades de Coordenação de Cursos de Graduação e Pós Graduação Lato Sensu. Membro da Academia Paulista de Psicologia, ocupando a cadeira no21.

\section{Roberto Ramos de Morais}

Possui graduação em Engenharia Mecânica pelo Centro Universitário da FEl (1983), mestrado em Engenharia de Produção - área Logística pela Escola Politécnica da USP (2004) e está cursando o programa de doutorado da Escola Politécnica da USP, Engenharia Naval, na linha de pesquisa de otimização de transportes. Atualmente é professor da Universidade Presbiteriana Mackenzie e da Faculdade de Tecnologia do Centro Paula Souza, campi Carapicuíba e Zona Leste. Tem experiência na área de Engenharia de Produção, com ênfase em Suprimentos, atuando principalmente nos seguintes temas: dinâmica de sistemas, logística, suprimentos, modelagem, estoques e sistemas de produção.

\section{Rodrigo Dos Santos Kelch}

Pós-graduado em logística e operações pelo Instituto Federal de Educação, Ciência e Tecnologia de Suzano (IFSP) e com Graduação Tecnológica em Logística pela Faculdade de Tecnologia de Guarulhos (FATEC). Tem experiência em centros logísticos, atuando principalmente nos processos de logística, prevenção de perdas, distribuição e suprimentos.

\section{Samuel Victor Ricardo Silva}

Formado em Logística Aeroportuária na Fatec Guarulhos do CETEEPS. Inglês e Espanhol básico- Fatec Guarulhos, conhecimento básico dos sistemas AutoCAD e ARENA. 


\section{Sueli Ferreira Colona}

Cursando Licenciatura em Formação Pedagógica de Docentes para a Educação Profissional de Nível Médio no Instituto Federal de Educação, Ciência e Tecnologia de São Paulo (IFSP), Pós-graduada em Logística e Operações pelo Instituto Federal de Educação, Ciência e Tecnologia de Suzano (IFSP), com Graduação Tecnológica em Logística pela Faculdade de Tecnologia de Guarulhos (FATEC) e em Comunicação Social com habilitação em Publicidade e Propaganda pela Universidade Braz Cubas. Tem experiência nas áreas de Comércio Exterior, Logística, Transportes, Suprimentos e Auditoria de Estoques, em operadores logísticos, armazéns alfandegados, centros de distribuições e indústrias.

\section{Suellen Yanes Da Silva}

Engenheira Química graduada pela Universidade Federal de Alfenas, em Poços de Caldas/MG . Atualmente, cursando Logística pela Faculdade de Tecnologia Baixada Santista - Rubens Lara, com previsão de término para o primeiro semestre de 2020.

\section{Thays Dos Santos Vasconcelos}

Formado em Logística Aeroportuária na Fatec Guarulhos do CETEEPS; Técnico em Finanças na ENIAC- Guarulhos; Técnico em Administração na ENIAC- Guarulhos, Curso técnico de Informática- Point Informática;

\section{Wadna Kimberlly da Silva Alves}

Pós graduanda em Gestão da Produção em Logística pelo Instituto Brasileiro de Formação IBF. Graduanda em Tecnologia em Logística pelo Instituto Federal de Educação, Ciência e Tecnologia do Amazonas - IFAM, Campus Manaus Distrito Industrial. Técnica em Administração pelo Instituto Federal de Educação, Ciência e Tecnologia do Rio Grande do Norte - IFRN. Linhas de pesquisa: Gestão da produção, Logística empresarial, Gestão Ambiental/Sustentabilidade e Logística Reversa.

\section{Wanny Arantes Bongiovanni Di Giorgi}

Mestrado em Controladoria e Contabilidade Estratégica pela Fundação Escola de Comércio Álvares Penteado - FECAP (2002). Especialização em Administração de Empresas com Ênfase em Análise de Sistemas, Fundação Escola de Comércio Álvares Penteado - FECAP (1989). Complementação Pedagógica com Ênfase em Orientação Educacional pela Faculdade de Filosofia, Ciências e Letras Professor Carlos Pasquale (1980). Curso de Formação para Professores do Ensino Médio em Contabilidade e Custos pela Faculdade Campos Salles (1978). Bacharelado e Licenciatura em Ciências Políticas e Sociais pela Fundação Escola de Sociologia e Política de São Paulo (1969). Técnico em Contabilidade pela Fundação Escola de Comércio Álvares Penteado - FECAP (1960). Registro Profissional no Conselho Regional de Contabilidade do Estado de São Paulo sob número CRC 1SP 096.213, ativo. Docência e coordenação do curso de Ciências Contábeis (2002-2011 UniABC). Docência no Centro Estadual de Educação Tecnológica Paula Souza - Fatec Guarulhos (2012 - atual). Membro do grupo de pesquisas registrado no CNPq sob a rubrica: Núcleo de Estudos em Contabilidade e Meio Ambiente NECMA, FEA USP (2009 - atual). Membro da Comissão Brasileira de Acompanhamento do Relato Integrado (2012-atual). Escritora (2003-atual) 


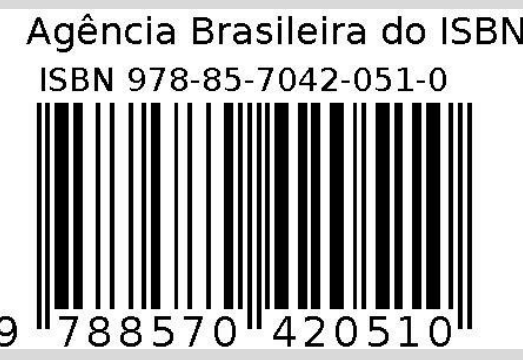

